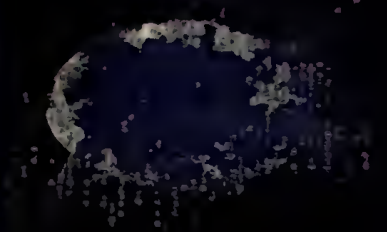


The Zibrary

of the

Unibersity of $\$$ 2orth Carolina

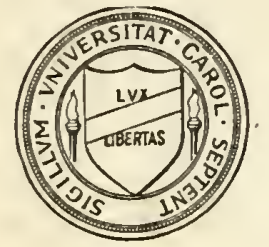

Endowed by The 哺ialectic

and

羽bilanthropic Societies

UNIVERSITY OF NORTH CAROLINA BOOK CARD Please keep this card in
book pocket

$-$
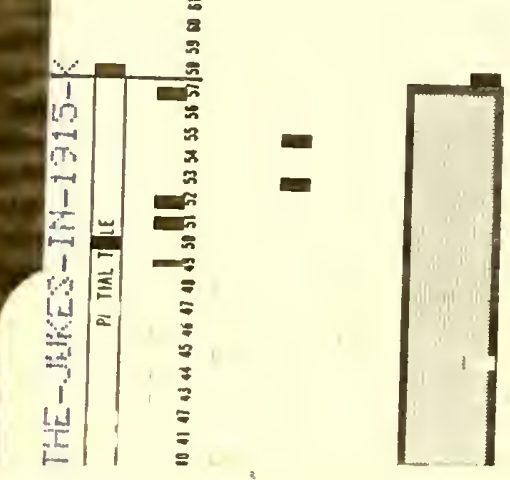

THE LIBRARY OF THE UNIVERSITY OF NORTH CAROLINA

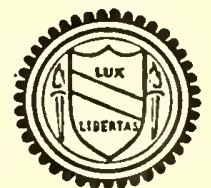

ENDOWED BY THB

DIALECTIC AND PHILANTHROPIC SOCIETIES 
This book is due at the LOUIS R. WILSON LIBRARY on the last date stamped under "Date Due." If not on hold it may be renewed by bringing it to the library.

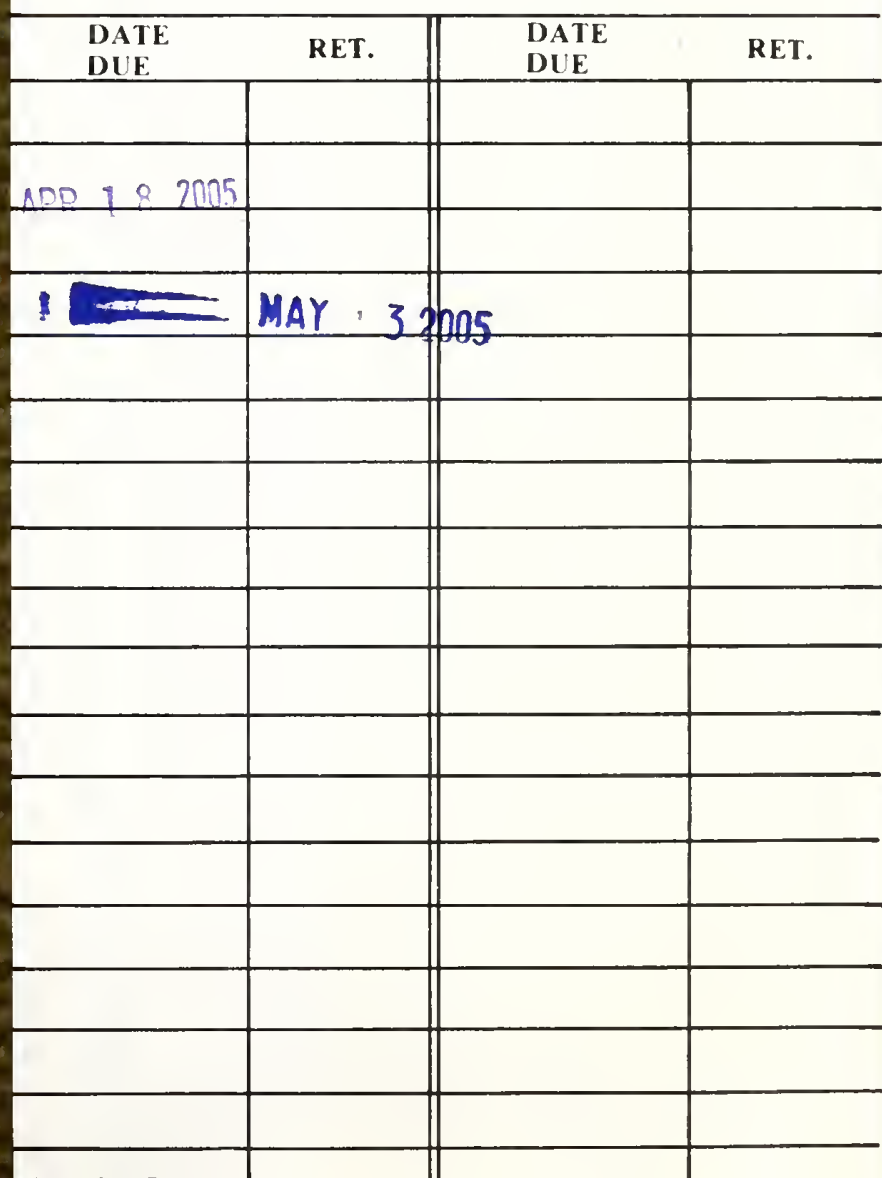



Digitized by the Internet Archive in 2013 



\section{THE JUKES IN 1915}

By Arthur H. Histabrook

Of the Eugenics Records Office

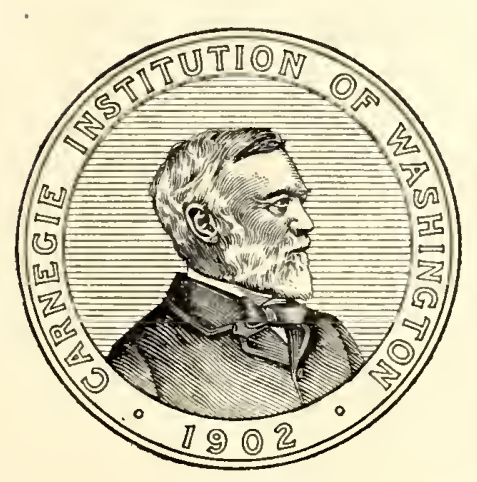

Published by the Carnegie Institution of Washington WASHINGTON, 1916 


\section{CARNEGIE INSTITUTION OF WASHINGTON}

Publication No. 240

Paper No. 25 of the Station for Experimental Evolution at

Cold Spring Harbor, New York

PRESS OF GIBSON BROTHERS, INC

WASHINGTON 


\section{PREFACE.}

Into an isolated region, now within two hours' railroad journey of the nation's metropolis, there drifted nearly a century and a half ago a number of persons whose constitution did not fit them for participation in a highly organized society. This region was the frontier of that day and those who went there had many of the characteristies of our western frontiersmen of a century later. Some of them were hunters, some of them extreme nomads (trampis), and like practically all extreme nomads were addicted to drink; some were miners and found at this place opportunity to make a living at an occupation that requires no capital and which may be readily abandoned or resumed; some were neurasthenic, found muscular activity and persistence in work irksome, and craved stimulants to lighten the labor of even minimum activities; some were feeble-minded and had found that Nature makes fewer demands on intelligence than does organized society; and still more were feebly inhibited and had either already so violently offended the mores as to flee the "revenge" of society, or had found that there was less tendency to repression of their intermittent, instinctive outbreaks where the arm of organized society was not yet long enough to reach. For all of such socially inadequate this retired, well-wooded, and well-watered valley afforded a haven of refuge at a day when the system of State "institutions" had been little developed.

That there shoukd be such strains in a colony that had been founded only three or four generations before is not strange when we recall that the emigration of criminals and ne'er-do-wells, among others, to this new country was assisted, in order to relieve the congested centers of Europe, of some of those whose presence was incompatible with the development of high civic ideals. It is the descendants of such people, among others, that came to the region which the Jukes family made notorious.

Here are some of the migrants or their immediate progeny: Max, the hunter and fisher, the jolly, alcoholic, ne'er-do-well; Lem, the stealer of sheep; Lawrence, the licentious, free with his "gun." Here, too, were found Margaret and Delia, the wantons, and Bell, who had three children by various negroes. So some negro and, doubtless, some Indian blood became in time disseminated through the whole population of the valley.

The progeny of such stock showed the expected reactions to their primitive environment. Some proved themselves feeble-minded, grew up ineducable, slovenly, and inefficient, ending their lives in the poorhouse. Some became vagrants, wandering hither and thither and sometimes disappearing from view altogether. Great numbers craved drink and regarded it as the greatest good and were unable to control in any degree their use of it as long as they had money or could be trusted for it. Great numbers saw no need of regulating and, indeed, many were unable to regulate their reactions to their sex impulses; so that they lived lives of grossest promiscuity in sex relations. Some showed an ugly and quarrelsome disposition. Others, like Ann Eliza, became delusional and homicidal. Indeed, assault and battery, murder, and rape are rather common, especially among the illegitimate children of Ada.

Not only was much of the original stock bad, but improvement which might otherwise have occurred was prevented by constant inbreeding. The nervous weaknesses, the mental insufficiencies were thus brought together from both sides and mentally and morally defective offspring were rendered more certain. Some outbreeding there was and, where it was with better stock, the progeny had better intelligence and emotional control and lines were founded that were able to hold a good position in organized society.

Such were the Jukes a generation or two ago, when Dugdale studied them. The special opportunity that the present investigation afforded was to note the later history of these strains in the presence of great changes of environment-changes that have forced the Jukes out of their ancient habitat and scattered them, that have broken up that propinquity that favored consanguinity, that have extended and rendered more effective the agencies of social betterment. What about the Jukes-forty years later?

First, on the whole, the later descendants of the Jukes, in Connecticut, in New Jersey, even in Minnesota, still show the same feeble-mindedness, indolence, licentious-) ness, and dishonesty, even when not landicapped by the associations of their bad fanily name and despite the fact of being surrounded by better social conditions. This is because, wherever they go, they tend to marry persons tike themselves. On the other hand, the dispersion has led some of these descendants to marry into better stocks and this is improving the quality of the germ-plasm. To be sure, this better germ-plasm into which the Jukes marry will sometimes become contaminated with the determiners for mental weakness and kack of control; but children who show such defects are more apt to be placed under restraint in their matings when they belong to families of fair social standing than when they arise in cacogenic communities. It is probable that, in the long run, the cheapest way to improve a bad germ-plasm is to scatter it. I do not, however, recommend this course as superior to segregation; but only as a cheap and somewhat hazardous substitute. In the case of the Jukes there are so many dominant traits of feeble inhilition that scattering them is like scattering firebrands-each tends to start a fire in a new place. One may doubt the wisdom of the operation of "Children's Aid Societies" which send much bad germ-plasm to good farming communities throughout our Middle West. It 
will probably have, on the whole, the same sad effects that the transportation of convicts from London to Virginia and later to Australia have had on parts of those countries.

The most important conclusion that may be drawn from Dr. Estabrook's prolonged study of the Jukes forty years later is that not merely institutional care, nor better community environment, will cause good social reactions in persons who are feeble-minded and feebly inhibited, although, on the other hand, better stimuli will secure better reactions from weak stock than will poor stimuli.
There is, indeed, no conflict between environment and heredity; each is a factor in all behavior. Environment affords the stimulus; heredity determines largely the nature of the reacting substance; the reaction, or behavior, is the resultant or product of the two. The great mistake that social agencies have made in the past is that they have overlooked the constitutional or hereditary factor of the reaction. The chief value of a detailed study of this sort lies in this: that it demonstrates again the importance of the factor of heredity.

\section{Carnegie Institution of Washington, Department of Experimental Evolution, Cold Spring IIarbor, Long Island, N. Y., May 23, 1916.}




\section{HISTORICAL NOTE.}

Richard L. Dugdale was born in Paris in 1841. His parents were English and came from an ancestry of much social distinction. When Dugdale was 7 years old his father suffered pecuniary reverses and returned to England. Despite careful inquiry, there is doubt as to what school Dugdale attended, but it is supposed that he went to Somerset School for about 3 years. In 1851 the family came to New York City, where Richard attended public school for several years. At the age of 14 he was employed by a sculptor, for whom he did very creditable work. He was very delicate in constitution and when he was 17 the family removed to a farm in Indiana with the hope of improving Richard's strength. Since two years on the farm effected no improvement in his physical condition, the malady being a serious heart trouble, the family returned to New York City. Within a year the father died, leaving a widow, Anna Dugdale, and three children, Agnes, Jane, and Richard. It is assumed that Agnes and Jane were older than Richard, as their names appear in the New York Directory for 1861 as proprietors of a linen shop, while Richard's name does not appear until 1864. They lived in several houses in Greenwich Village until 1871, when they moved into a house now standing at 4 Morton Street, near Bleecker Street. It was in this house that all the nembers of the family spent the remainder of their lives. Around the corner from 4 Morton Street, at 250 Bleecker Street, the two sisters had their linen shop. After returning to New York Dugdale entered business and in the evenings attended night classes of the Cooper Union, where he distinguished himself in the debating clubs. He became greatly interested in social science and keenly desired to devote himself to the scientific study of social phenomena. He afterwards said of this time:

"At twenty-three, I clearly saw that, even did I possess the most perfect technical training to enable me to analyze the complex questions involved, there was no institution or patron to defray the expenses of a continuous, calm, independent, and unconventional critical study of social phenomena. I, therefore, had to confront this practical question-to earn the costs of an education which no college provided and amass sufficient fortune to purchase the privilege of independent subsequent enquiry. I met the dilemma by entering the career of merchant and manufacturer, because this combined the opportunity for study of a distinct class of social phenomena and the promise of earning means for future freedom of investigation. After ten years of this double work, I broke down in health, yet I continued business for two years more, until my physicians peremptorily ordered rest, physical and mental; and for four years I could neither earn nor learn."

It is to be regretted that Dugdale, with his sympathetic outlook upon and intelligent insight into social behavior, could not have been aided by such present-day institutions as the Eugenics Record Office, the Carnegie, Russell Sage, and other foundations.
How active and multifarious Mr. Dugdale's interest in social subjects was one can easily infer from an imperfect list of the bodies of which he was a zealous and important member. He was secretary of the Section on Sociology of the New York Association for the Advancement of Science and Arts, of the New York Social Science Society, and of the New York Sociological Club; treasurer of the New York Liberal Club; and vice-president of the Society for the Prevention of Street Accidents. He was later, for a time, secretary of the Civil Service Reform Association, and an active member of the American Social Science Association and of the American Public Health Association. He was also a member of the American Free Trade League, of the Chamber of Commerce, and of the American Institute.

He was interested in the amelioration of the condition of man. In 1868 , at the age of 27 , he became a member of the executive committee of the Prison Association of New York. The work of this association was two-fold: first, the bettering of the mental and physical condition of prisoners while in prison; secondly, practical help to them after discharge. Dugdale spent much time, energy, and money in this work. He made many visits to the different State prisons and jails of the State. He came into intimate touch and relations with prisoners of all sorts and kinds. He learned their stories and, as Mr. Shepard says, their "case against society, as well as the more obvious though perhaps no stronger case of society against them." That Dugdale was an active member of the Executive committee of the Prison Association is shown by the fact that he was present at practically every meeting of the executive committee from 1868 to 1880 . He was secretary pro tempore many times and his writing in the minutes shows a nervous, quick hand. A facsimile of his writing and signature is shown here:

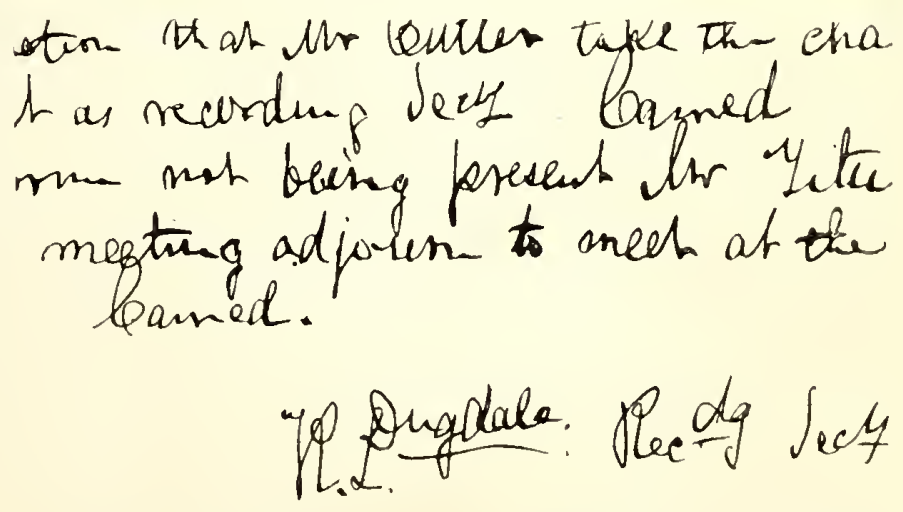

In July 1874 Dugdale was appointed a committee of one to inspect thirteen of the county jails of the State of New York. The corresponding secretary of the Prison Association, then Dr. Elisha Harris, had made a hist of questions for each prisoner, which included items about the heredity, 
education, diseases, industrial training, moral and intellectual capacity, pauperism, and crime; and an estimate of the probable fate of the person questioned. With this as a guide to inquiry the tour of the county jails was made in the summer of 1874. "The Jukes" and a "Further Study of Criminals" resulted. The author of "The Jukes" became so interested in this subject that practically all the expense of his investigation was borne by him. After the publication of the two studies on criminals, Dugdale read a paper on "Hereditary pauperism as illustrated in the Juke family" at the conference of charities held in connection with the general meeting of the American Social Science Association at Saratoga, New York, in September 1877. Mr. Dugdale then published several short essays in the Westminster Review, the Atlantic Monthly, and the North American Review. One of these, "The Origin of Crime in Society" (Atlantic Monthly, 48 and 49), traces the development of crime from savagery to civilization, discusses the factors which produce it, and reaches the conclusion that prison treatment does not cure crime. Among other things, Dugdale suggests that the true function of a prison is for the permanent retention of murderers and those committing violent crimes. Dugdale did much literary work for the organizations of which he was a member. Shepard, in "The Work of a Social Teacher," says that "his literary style was attractive, nervous, and vigorous." He had "a considerate deference to the opinion and studies of other men, and with a modest and continuous acknowledgment of the large extent and complex nature of the problems upon which he was engaged, always forbidding, as they did, narrow and dogmatic assertions."

In 1880, Dugdale was chosen secretary of the newly formed Society for Political Education. This society was founded by R. R. Bowker, E. M. Shepard, A. E. Walradt, David A. Wells, W. C. Ford, George H. Putnam, and William M. Ivins, of New York City. These nen founded this society in the belief "that the success of the government depends on the active political influence of educated intelligence, and that parties are means, not ends." This society issued many pamphlets on political questions of the day, including taxation, work and wealth, civil service reform, and money and its substitutes.

Dugdale died on July 23, 1883, at his residence, 4 Morton Street, New York City, made familiar by him as the office of the Society for Political Education. The same heart disease which followed him through life caused his death. Mr. R. R. Bowker, who knew Dugdale well, says that he was a modest man of frail physique. He was thin, of fair height, spare, and always abstemious. He was not of striking personal appearance, but on the contrary had almost no presence. He was rather reticent about his early life, saying that his own personality and life were of no import. He was unpretentious but efficient, and gave all his time to altruistic work.

Mr. George Haven Putnam, the publisher, said:

"Dugdale was a man of exaggerated unselfishness, and extreme modesty, and in a discussion would rather assent to the other's opinion than to force his own. He entirely lacked personal ambition."

In his "Memories of a Publisher" (pp. 171, 172), Mr. Putnam writes:

"Dugdale was an Enghishman who had inherited a small competency that saved him from giving daily hours to business work. He had large ideals for the education of the community. He had convinced himself, as many other public-spirited men have convinced themselves, that if representative government is not to be a farce, the fighting power must be in the hands of voters who possess adequate information in regard to the issues to be decided from election to election, and who possess further a sufficient training to utilize such information and to arrive at an intelligent judgment for their action as citizens.

"Dugdale had a great belief in the influence of reasonable argument. He thought that the voters of a community could be educated to a public-spirited understanding of its duties by means of tracts, monographs, political sermons, etc."

Dugdale was much attached to his sister, Jane Margaret, an invalid. He was never attracted to other women, and was very shy and retiring in their presence. The older sister, Agnes, and the mother died before he did. Jane survived him a short time, dying August 27, 1884.

Jane Dugdale, by her will, gave all her residuary estate to four persons to form a corporation to be known as the "Richard L. Dugdale Fund for the Promotion in the United States of Sound Political Knowledge and Opinions." The committee which received this property consisted of Messrs. Bowker, Ford, and Shepard. For some years the bequest and its income were used for purposes of that character and on January 30,1900 , the balance $(\$ 1,311.72)$ was turned over to the New York Public Library with a request that it should be expended for books on sociological and economic subjects, the fund to be known as the Richard L. Dugdale Fund. With this money about a thousand books on economic subjects have been purchased by the library and are now on its shelves: a small but fitting memorial to one who gave, without seeking or obtaining any adequate recognition, his best years and most fruitful labor to the service of humanity. 


\section{CONTENTS.}

PAGE

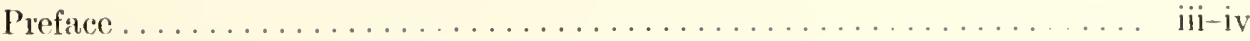

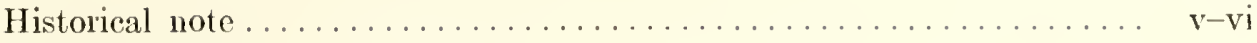

I. Introduction . . . . . . . . . . . . . . . . . . . . . . . . 1

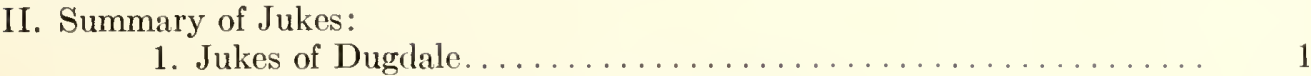

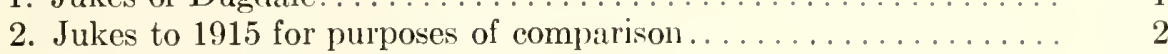

III. Habitat and social status........................... 2

IV. The first two generations of Jukes . . . . . . . . . . . . . . . . . . . . . 2

V. Descendants of Ada's illegitimate child (chart 1) . . . . . . . . . . . . 3 17

VI. Descendants of Ada's legitimate children (chart 2) . . . . . . . . . . . 17-27

VII. Descendants of Bell Juke (chart 3$) \ldots \ldots \ldots \ldots \ldots \ldots \ldots \ldots$. . . . . . . . . 28-34

VIII. Descendants of Clara Juke (chart 4) . . . . . . . . . . . . . . . . . 34-36

IX. Descendants of Delia Juke (chart 5) . . . . . . . . . . . . . . . . . 36-41

X. Descendants of Effie Juke $($ chart 6$) \ldots \ldots \ldots \ldots \ldots \ldots \ldots \ldots \ldots$. . . . . . . . 41-50

XI. Population . . ................................. 50

XII. Marriage relations. . . . . . . . . . . . . . . . . . . . . . . . . . 51

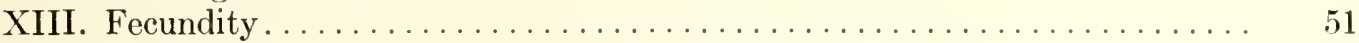

XIV. Legitimacy . . . . . . . . . . . . . . . . . . . . . . . . . . 51

XV. Consanguinity in marriage $($ charts $7-10) \ldots \ldots \ldots \ldots \ldots \ldots \ldots \ldots$

XVI. Studies in special traits:

1. Harlotry (charts 11-17) . . . . . . . . . . . . . . . 56-62

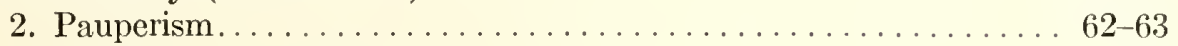

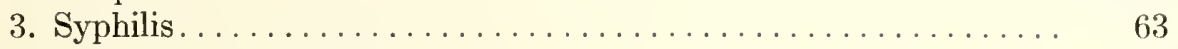

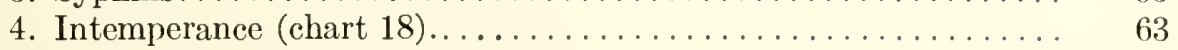

5. Crime $($ charts $19-21) \ldots \ldots \ldots \ldots \ldots \ldots \ldots \ldots \ldots \ldots \ldots$

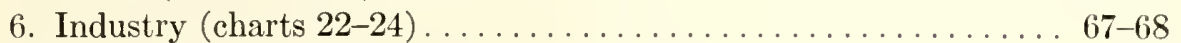

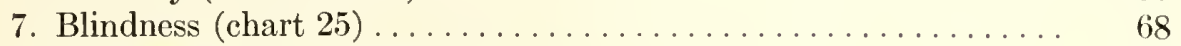

8. Shyness, temper, and speech defect (chart 26) . . . . . . . . 69

9. Twinning (chart 27) . . . . . . . . . . . . . . . . . . 69

10. Absence of harelip and cleft palate.................. 69

XVII. Changed environment:

1. Voluntary removals to a new country . . . . . . . . . . . . . 69-70

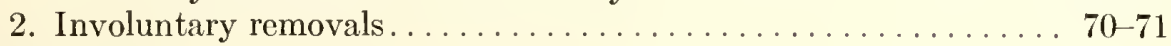

XVIII. Institutional care:

1. Children's institutions....................... 71

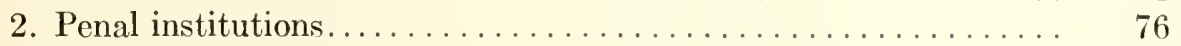

XIX. Insanity . . . . . . . . . . . . . . . . . . . . . . . . . . . 77

XX. Epilepsy (chart 28) . . . . . . . . . . . . . . . . . . . . . . 77

XXI. Eugenic matings. . . . . . . . . . . . . . . . . . . . . . . . . 77

XXII. Social damage. . . . . . . . . . . . . . . . . . . . . . . . . . . . . 78

XXIII. Conditions under which improved individuals or strains of Jukes have arisen . 78

XXIV. Statistical summaries of the Jukes:

Summary table of Jukes living in $1915 \ldots \ldots \ldots \ldots \ldots \ldots \ldots$

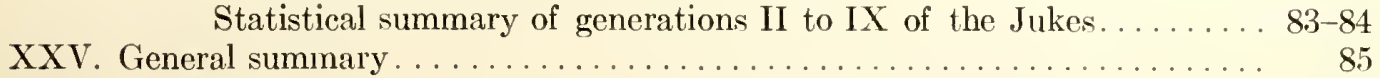

XXVI. Literature cited . . . . . . . . . . . . . . . . . . . . . . . . . . 85 


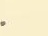




\section{THE JUKES IN 1915.}

\section{INTRODUCTION.}

In 1875 Richard L. Dugdale made the first public announcement of his sturly of the Juke family in the annual report of the Prison Association of New York, of whose executive committee he was a member. In July 1874 he was chosen a committee of one to inspect thirteen of the county jails of the State of New York. He made a tour of the State, inspected the jails, and in each place asked of every prisoner a set of questions which had been formulated by him with the help of Dr. Elisha Harris (then corresponding secretary of the association) regarding the prisoner's' heredity and enviromment. No particular cases of striking family history were discovered until he reached $Z$ County, where he found six persons undler four family names, who were blood relations in some degree. "The oldest [Benjamin, see charts 3 and 1, IV 63], a man of fifty-five, was awaiting trial for receiving stolen goods; his daughter [VI 217], aged eighteen, held as witness against him; her uncle [Antonio, V 66], aged forty-two, burglary in the first degree; the illegitimate daughter of the latter's wife, aged twelve years, upon which child the latter hark attempted rape, to be sent to the reformatory for vagrancy; and two brothers in another branch of the family [VI 2 and VI 4], aged respectively nineteen and fourteen, accuserl of an assault with intent to kill, they having maliciously pushed a child over a high cliff and nearly killed him." Consultation with the sheriff of the county and with a physician 84 years of age, who had practiced in that and neighboring counties, showed that these people belonged to a long lineage, reaching back to the early settlers of New York State, and that they harl intermarried little with immigrant stock, and were therefore a strictly American family.

In 1877 the report was again published, this time in book form, by G. P. Putnam \& Sons, and is now in its fourth edition. The book has been widely read and has had a great influence. It has stimulated discussion and led many to sturly the interaction of the "forces of heredity and enviromment." Dugdale was very cautious in the conclusions which he drew. The book does not demonstrate the inheritance of eriminality, pauperism, or harlotry, but it does show that heredity with certain environmental conditions determines criminality, harlotry, and pauperism.

In this book, as in Dugdale's, all names are fictitious. It has seemed best, for purposes of the treatment, to assign names to certain heads of families in the middle generations as Dugdale dirl in the earlier. The original dlata are on file at the Eugenies Record Office, Colsl Spring Harbor, New York.

The present study of the Juke family was marle possible by the chance diseovery of the original manuscript Juke record of Dugclale. In the fall of 1911, Mrs. O. F. Lewis, wife of the General Secretary of the Prison Association of New York, while looking over a lot of papers stored away in the cellar of the Prison Assoriation building, found this valuable paper in Dugdale's handwriting. It was recognized by Dr. Lewis, who kindly gave the Eugenies Record Office permission to copy the names and other rlata not found in the Juke publication. With the names as a foundation the present study has resulted.

In January 1912 the investigation was started. It has been persistently carried on for three years in fourteen States of the Union. Every Juke possible to see has been personally visited. It is hoper that inaccuracies in the following report are few. Care has been taken to check all data secured, and the writer feels it to be as free from error as possible, considering the limits of time and expense. Official records from State prisons, county clerks' offices, and sheriffs' books have been userl for data as to crime. Records of State Boards of Charities, almshouses, and poor commissioners have been used for data of pauperism. Other institutional records have been used in suitable cases. In every instance free access to all records has been willingly given; without this cooperation this study would be very incomplete. Particularly helpful has been the interest of the county officials of $Z$ county, especially the two county judges who held office during the course of the study. The rest of the data was secured from observation by the investigator and from conversation with others. When informants are biased in their opinion of the Jukes and their traits, or are suspicious of a wrong inotive on the part of the investigator, the problen of accuracy becomes more difficult. It is possible sometimes to overcome this by a study of the informant. Owing to the fact that the people described are studied and weigher by one person, the comparisons marle have a special value. The standard of the investigator, to be sure, will vary from time to time, but the pendulum will not swing far from the mean.

\section{SUMMARY OF JUKES.}

\section{JukEs OF DUgDALe.}

Dugdale studied 709 persons, 540 being of Juke blood and 169 of " $\mathrm{X}$ " bloor who hard married into the Juke family. He estimated that the Juke family would consist of 1,200 persons were it possible to have traced all the lines of descent from the original 6 sisters. Of the 709 whom he studied, 180 had either been in the poorhouse or received outrloor relief to the extent of 800 years. There harl been 140 criminals and offender's, 60 habitual thieves, 7 lives sacrificed by murder, 50 common prostitutes, 40 women venereally dliseased contaminating 440 persons, and 30 
prosecutions in bastardy. The total cost to the State of New York of this one group of mental and social degenerates was estimated, for a period of 75 years beginning in 1800 , at $\$ 1,308,000$.

\section{Jukes to 1915 for Purposes of Comparison.}

In the present investigation, 2,820 people have been studied, inclusive of all considered by Dugdale; 2,094 were of Juke blood and 726 of " $\mathrm{X}$ " blood who married into the Juke family; of these 366 were paupers, while 171 were criminals; and 10 lives have been sacrificed by murder. In school work 62 did well, 288 dicl fairly, while 458 were retarded two or more years. It is known that 166 never attended school; the school data for the rest of the family were unobtainable. There were 282 intemperate and 277 harlots. The total cost to the State has been estimated at $\$ 2,093,685$.

\section{HABITAT AND SOCIAL STATUS.}

Situated at an elevation of 200 feet above sea-level, in a rugged, hilly, thinly populated, woody region, is a chain of five lakes. The first three of these, much smaller than the other two, are almost surrounded by high, overtowering rocks which descend into the lakes so steeply that in some places there is no foothold to be had at the water's edge. Between huge clefts in the rock are small patches of land once the home of the early Jukes, but now desolate except for the wild animals which hive in the caves once used by the Jukes as both homes and places in which to hide stolen booty. Here a sum of $\$ 90,000$, stolen in a bank burglary, was hidden for some time. 'The other two lakes are much larger and are situated $1 \frac{1}{4}$ miles from the first three, and are in a comparatively fertile and populous region. The rocks which compose this mountain ledge were useful for cement, and the working of this rock furnished employment to many Jukes. The unused tunnel openings and crumbled-clown cement burner's may still be seen, although unused for the past 30 years. Many of the Jukes, devoid of personal fear, and fond of hazards, worked in these mines. One of the Jukes living at present has many pieces of cement rock embedled in the flesh of his face, neck, and shoulders, as the result of an explosion while thus employed.

Most of the original Jukes were squatter's on the soil and became owners by occupancy. They lived in stone or $\log$ houses, usually of one or at the most two rooms, the men, women, and children intermingling freely. Here the Jukes lived for a period of 100 years. The cement industry was discontinued in 1880, owing to the introduction of Portland cement, and a general exodus of the remaining Jukes took place. Now there is not a single Juke living in the ancestral area, and only ruins of these abodes remain.

As the Jukes increased in number a community of criminal men, semi-industrious laborers, and licentious women developed. Children grew up in an atmosphere of poverty, crime, and licentiousness. The girls and young women of these families were very comely in appearance and loose in morals. This combination attracted the men from a nearby city, even those of socalled "good" families. These illicit unions brought forth many an illegitimate child, named usually after the supposed father; as a result one finds among the Jukes some of the most honored names of the region. In this way syphilis has been spread from these harlots to the good and virtuous wives in the nearby community. These Jukes were and are still so despised by the reputable conmunities nearby that the statement of Dugdale's that "their family name had come to be used generically as a term of reproach" is still true. If anyone in the community now commits even a slight indiscretion he is told that he is acting like a "Juke." The owner of one factory in $Z^{2}$ kept a list of Juke names in his office. When anyone applied for employment and his family name appeared in the list, he was refused work. "Such is the feeling of the community towards the Jukes.

\section{THE FIRST TWO GENERATIONS OF JUKES.}

It was in this region, inaccessible and unfertile, that Max was born somewhere between 1720 and 1740 . He is described as "a hunter and fisher, a hard drinker, jolly and companionable, and averse to steady toil." He worked by spurts and became blind in his old age. He had many children - two of whom, Harry and Harvey, married two out of six sisters. All these six sisters were children of the same mother and four bore the same family name, while the name of two seems to be obscure, and these are for this reason assumed to be illegitimate. One of these six sisters left the country and nothing is known of her. The other five are the renowned Juke sisters, Ada, Bell, Clara, Delia, and Effie.

Ada, II 1, who is better known both in $Z$ County and to the general public as "Margaret, the mother of criminals," was born about 1755 . She had one bastard child, Alexander, III 1 , whose descendants are shown in chart 1 . The group of Jukes that descended from Alexander is called the illegitimate posterity of Ada. Soon after this, Ada married Lem, II 2, and had four legitimate children (shown in chart 2), who formed the legitimate posterity of Ada. Ada was temperate and healthy, but not industrious, and in her old age received poor relief. Lem is described by Dugdale as follows: "Laborer; lazy; no property; outdoor" relief; healthy; temperate; thief; received thirty lashes for sheep stealing; died 1810."

Bell, II 3, sister of Ada, had four bastard children before marriage, three of them mulattoes. She was unindustrious and a pauper, much like her sister. She had no property, received outdoor relief, and was temperate. She married Bruce, II 4, and died in 1832. Bruce was a Revolutionary soldier and received a pension. He was not industrious, never acquired any property, and received outdoor relief. He was temperate and not climinal. They had four legitimate children. The descendants of Bell, both illegitimate and legitimate, are shown in chart 3.

\footnotetext{
${ }^{1}$ Loeally instead of the word Juke being used the name of the five lake: is supplied.

${ }^{2} Z$ refers to a eity of 20,000 people near the five-lake region where the Jukes lived. $Z$ County is the eounty in which $Z$ is situated and is the present home of many of the Jukes. $Y$ is a small village in $Z$ County, about one mile from the lake region.
} 
Clara, I1 5, the third of the five sisters, was reputed chaste. Her legitimate posterity are shown in chart 4. She married Lawrence, II 6, who was licentious and had shot a man.

Delif; II 8, the fourth sister, had two bastard and five legitimate chilchen. Of Delia, nothing is known further than that she was a prostitute. She married Harry, II 7, son of old Max. Nothing is known of Harry. The bastard children of Delia had no offspring. Her descendants are shown in chart 5.

There is no personal information about Effie, II 10, the last of the five sisters. She inarried Harvey, II 9, the other son of old Max mentioned above, who was probably a thief. They had four children, and their kescendants are shown in chart 6 .

\section{DESCENDANTS OF ADA'S ILLEGITIMATE CHILD.}

\section{(Chart 1.)}

The first of the five Juke sisters was Ada, II 1. She was born probably between 1755 and 1760 . She was "a harlot before marriage; not industrious; healthy; no property; not criminal; and receiver outdoor relief in her old age." She had one illegitimate child, Alexander, III 1. The descendants of Alexander are listed in chart 1 of the present book. Ada married Lem, II 2, and had a legitimate posterity shown in chart 2. The illegitimate posterity of Ada, $i$. e., the descendants of Alexander, will now be described.

Alexander was born in 1784 . He was somewhat industrious, a laborer, honest, and temperate. He had no property, received no outdoor relief, and was not a criminal. He married his first cousin, Beatrice, III 18, a daughter of Bell Juke (chart 3). She was "reputable, temperate, not criminal, healthy, and not a pauper." These two lived in the ancestral breeding-spot of the Jukes, "along the forest-covered margin of five lakes, so rocky as to be at some parts inaccessible." Alexander and his wife were squatters on the soil, as were the other original Jukes. This couple had six children: Abe Isaac, IV 2, Alice, IV 5, Albert, IV 7, Amanda, IV 9, Alfred, IV 11, and Amelia, IV 12. All of these were anti-social, though neither parent was. A description of their descendants now follows.

The oldest of their children, Abe Isaac, was licentious when young. He would work well on a spurt, but not steadily. He was reputed to be a sheep-stealer, but was never caught. He had a quarrelsome disposition, was an habitual drunkard, and a recipient of poor relief in his old age.

The second child, Alice, was somewhat inclustrious and temperate. She became a prostitute at the age of 35 while her husband was in State prisoll, sentenced for 5 years. She received town help at different periods during her whole life, and died at the age of 70 .

Albert, the third child of Alexander, kept a tavern and brothel, was a thicf but was never caught, and a recipient of poor relief during practically his whole life. He inherited a few acres of land, upon which he lived at the age of 67 , and died at the age of 79 .

The fourth child of Alexander was Annancla. She was a harlot and a pauper, and nearly blind.

Alfred was occasionally intemperate, though an industrious mason. He received much poor relief from the age of 46 until his death.
Amelia was a harkot, who lad been placed in the poorhouse for debauchery in 1852 at the age of 22 . All trace of her disappears at this point.

This gives a picture of the crime, debauchery, and pauperism in the first generation following the cousin mating of Alexander and Beatrice. The descendants of each one of their five children will be described in turn.

Abe Isaac's first consort, Lottie, IV 1, was a harlot. He had one child by her, Ann Eliza, V $1 .^{1}$

Ann Eliza, who was also a harlot, had been in the poorhouse and received outdoor relief. She cohabited with her second cousin, Ephan, V 414, a great grandson of Effie Juke. Ephan was a steady worker and acquired a little property, $i$. e., a half acre lot and a hut. He was, however, an habitual drunkard and received help from the town for many years. Neither he nor Ann Eliza could read or write. 'They were not married until all their children were born and they had been living together 10 years. Then, both intoxicated, they celebrated the event by dancing down the tow-path near their home. In 1875, during a drunken fight, Ephan was severely pounded by his wife and son, VI 6, also drunk. Ann Eliza was sent to the penitentiary for 6 months for this act, and the boy to the House of Refuge. Ephan then cohabited with Golden, V 415 (chart 6). Ann Eliza became homicidal and delusional after her release from imprisonment, and was sent to a hospital for the insane, where she died in 1908.

Ephan ched in 1906. He had several children by Golden (chart 6). He had seven children by the cousin mating, two of whom died in infancy: VI 6 , above mentioned, who left the House of Refuge and died at the age of 17, and four other children-two boys, VI 2, VI 4, and two girls, VI 7 , and VI 10. The two boys were arrested in 1870 for nearly killing a boy by pushing him over a cliff. The older was discharged, but the other, at the age of 14 , was sent to State prison for 5 years.

VI 2 is now a man of 70 . He has made a poor living by fishing, hunting, and trapping, and has been arrested many times for not obeying the game laws. He is very intemperate and while intoxicated, though harmless, frightens the neighbors for miles around by his wild cries and shouts. He has an ugly disposition, and his temper is very easily aroused. He seduced and then marricd VI 1, a shrew, by whom he had seven children, only one dying in infancy.

The first child, VII 2, has attended school but little, and then did not keep up with his classes. He lias a quiet disposition and does what he can to support his family, which consists of a wife (neat, inchustrious, and of good repute) and four living children. The first child, VIII 1, is now 18, has St. Vitus dance, and is rapidly becoming mentally deteriorated; the second, VIII 2, is doing average work in school; and there are two still young.

The second child of VI 1 and VI 2 is VII 4, an ignorant laborer. When young he was married to a harlot, by whom he had two children, one of whom died.young. The woman and the remaining son disappeared and since then the husbanel has cohabited with another woman. At 19 he was arrested and fined for disorderly conduct. At 29 he and his family received town help for a period of 4 years. From 30 on he has been arrested many times for drunkenness, butnever sentenced. At 35 he was arrested for breaking the ear-trumpet belonging to a deaf boy, but, after

${ }^{1}$ Dugdale states that there were no ehildren from this mating and ineludes Ann Eliza among the ehildren of the seeond eonsort. 
making good the damage he had done while drunk, he was discharged.

The third child of VI 2, a boy, died in infancy.

The fourth child, VII 7, did not learn easily in school, but, nevertheless, grew up a quiet, well-behaved, ambitious boy. At 20 , soon after marriage and the birth of a child, he died of typhoid fever.

The fifth child, VII 8, was an exceptionally bright boy in school. He went away from the Juke region, was industrious, and did well. He visited his parents at their home, did not return to his good position, married a reputable girl belonging to a disreputable family, and has gradually degenerated socially to the Juke level. He is now intermittently industrious, has little ambition, and seems to be reverting to the ancestral type. He has two small children.

The sixth child of VI 2 (VII 10) did well and was of good behavior in school. After leaving school she went to work in a factory and soon became a harlot. She married and has four children. Her husband is industrious and provicles a good home for her. When his work calls him away, which is often, she frequents a saloon near her home in the country.

The last child in this family, VII 12, is an inefficient, quarrelsome young fellow. He works at times, mainly as a laborer, or hunts and fishes. Some time ago he was arrested for fighting with his father, both of them being intoxicated at the time. He is now married, is poor, and bids fair to repeat the history of his ancestors. This ends the story of the descendants of VI 2.

After the discharge of VI 4 from the five-year term in State prison for assault, he returned to the Juke country and there cohabited with his cousin, VI 722, a descendant of Delia Juke. Living at the present time, he can neither read nor write, is intemperate, and although a steady worker, earns but little, as he is an untrained laborer. His consort, an ignorant, slovenly, intemperate, and inefficient woman, had two bastard children before cohabitation with him. The first is dearl. The second, VII 16 , is a feeble-minded harlot, who has had two illegitimate children and is now cohabiting with a man to whom she is not married. It is not known that VI 4 ever went through a marriage ceremony with VI 722.

Their first child after' cohabitation is VII 19. 'This girl was unable to learn in school. She married a cousin, VI 846 , but soon deserted him to live with her second cousin, VI 531, who had another wife living. This man has served many jail sentences for disorderly conduct, has been in a reformatory, and is inefficient, semi-industrious, ignorant, and mentally defective. This pair lived together 11 years and had five children, one of whom died in infancy. In 1911 they separated. The woman has run a brothel in a nearby city since, and has served a term in the penitentiary and one in the county jail for disorderly conduct. We shall hear more of the man later. Three of the children, aged 6,3 , and 2, respectively, were placed in a Children's Home when the parents separated, and the fourth was left with her grandmother, VI 722. After a short stay in the Home, the three were adopted into good homes in the Middle West. The oldest, VIII 17 , now 9 , is in only the second grade, although she has attended school regularly for the past three years, and tests up to her chronological age by the Binet test. Her brother, VIII 18, aged 7 , is now doing well in the first grade in school. 'They are both well-behaved children and well thought of in their new home. The youngest of the three, who has been placed in the Middle West, is only 5 years old, and but little can be said of her now.

The second child of VI 4, VII 20, was born in 1886 and went to school until she reached the fourth reader. She married at the age of 18 , and, soon after her first baby died, at the age of a few weeks, she left her husband and became one of the most notorious public women in the neighborhood. She was tall and handsome, a heavy drinker, morally very low, and went to any extreme to earn a poor livelihood by prostitution. In 1911 she was sent to the penitentiary for 6 months for disorderly conduct, but, upon her release, immediately returned to prostitution. She was found dead in the woods back of her home, where she had lain in the rain for several days. It was finally decided that she died of heart disease, brought on by her life of vice, although foul play was at first suspected.

Next in turn in this family comes a boy, VII 23 , who is like his brother, VII 25. Both were slow and very much retarded in school work, have grown up indolent, inefficient, and with no desire or ambition to get along in life. Needless to say, both are licentious.

Next younger to VII 23 is VII 24, now 21, who was unable to grasp third-grade work in school, and later could not learn to be a competent housemaid. She became pregnant in 1911, was arrested later for disorderly conduct, and then married a mentally defective cousin of hers, VI 527, to father her unborn child. The family has received poor relief for the past year.

Her two younger sisters, VII 26 and VII 27, were retarded in the work in school, left early, and went to work in a cigar factory. They are now harlots. This completes the offspring of VI 4 and VI 722.

The fourth child of Ephan died in infancy. 'The fifth, VI 6 , has previously been described.

The sixth child, VI 7, was sent to the House of Refuge for disorderly conduct at the age of 14 , in 1875 . Here she remained three years, acquired a little schooling, and the ability to read and write. However, on leaving the institution she again became a harlot. At 18 she married a licentious, semi-industrious man, who did little to support her or, later, her many children. About 1900 her husband deserted her. She has worked hard to earn a livelihood by taking in washings, has a subnormal mentality and a disagreeable temper, and has run a brothel in her own home with her daughters as inmates.

The eldest child of VI 7, VII 29, is lazy, intemperate, and a wanderer. His first wife died, leaving him a girl who is now 12, good-mannered, but retarded in school work. His second wife, a harlot, divorced him when she found that he was intimate with another woman.

The second child of VI 7 was mentally incapable of work in school. She became a harlot, later married, had one child, continued her harlotry, and was finally divorced by her husband. Her neat and well-dressed appearance does not give the impression of the character she has become. 


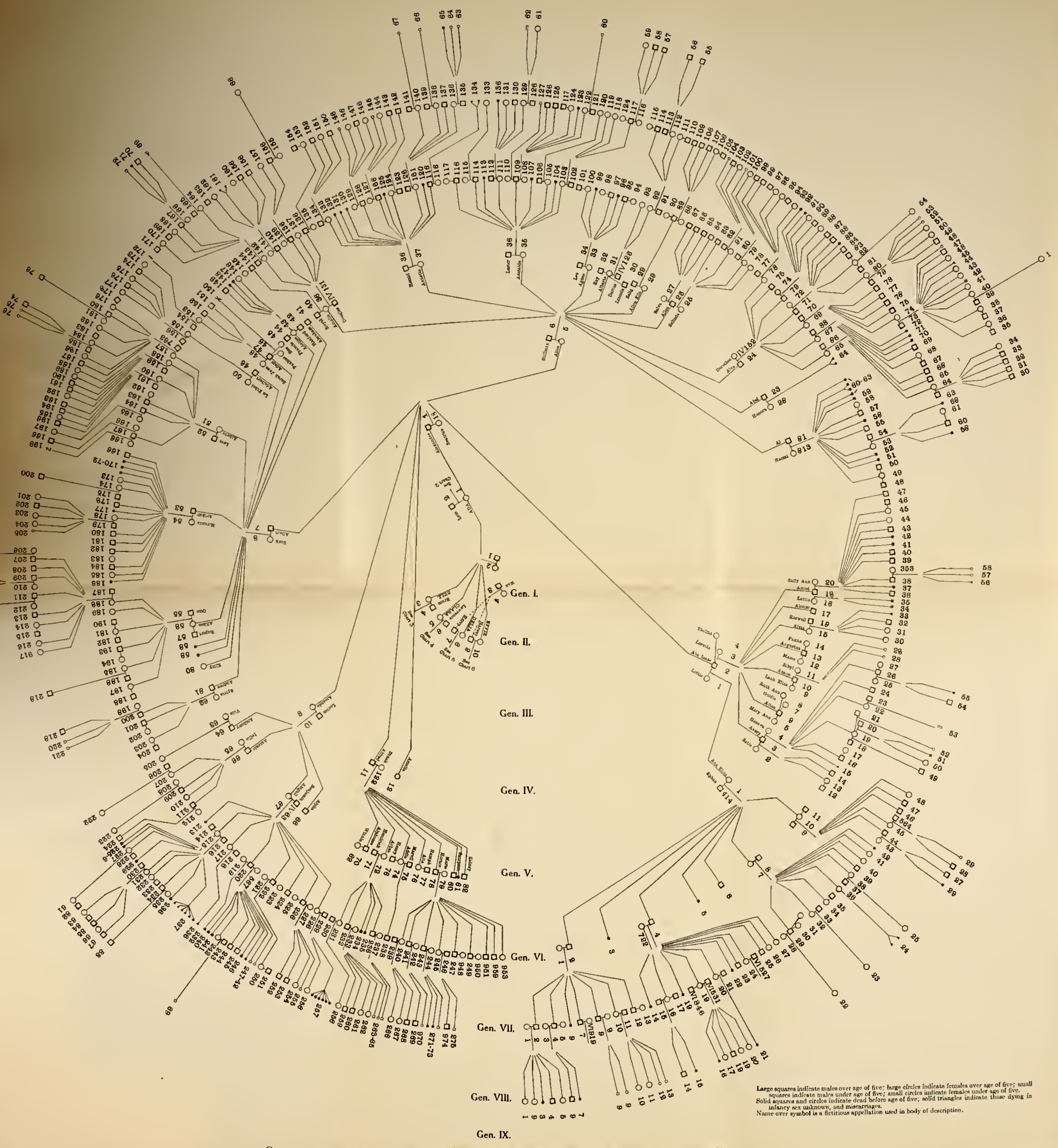

Chart 1. Genealogical Tree of the Descendanty of the Illegitimate Child of Ada Juke, ns recorded in 1915. 
. 
The two sister's, VII 34 and VII 36 , are semi-industrious and harlots. One was divorced by her husband for infidelity; the other, VII 36, has had two illegitimate childrer, both of whom died at birth.

The next daughter, VII 38, became a prostitute at the age of 14 and was sent to the State Training School for Girls. She made a good record for a short time after leaving the institution, married, and has one child. At 18 she was again arrested for disorderly conduct and, at 22 , in 1914, she is found in a house of prostitution.

The next child in this series is a boy, VII 39, wellinclined in school but incapable of carrying on the work. He is quite a "dandy" in his dress and is very fond of music, but dislikes work.

The last two children in this family were girls, VII 40 and VII 41, now aged 19 and 17 , respectively. The former was dull in school; the latter "bright." They are now harlots and are running a house of prostitution.

The last daughter of Ephan and Ann Eliza, VI 10, was sent to the House of Refuge as a disorderly child. She was later indentured and the reports say that at 17 she was disobedient, dishonest, and immoral. She married a steady and rather industrious though ignorant man, VI 9, when she was 18. They had five children. The husband was accidentally shot in 1894. The wife has supported the family since then. She has cohabited since his death with a worthless individual who has not given her any support.

The oldest child of VI 10 is a boy, VII 44, now 25. He is an industrious young fellow, and has kept his family well. He is married to a neat, industrious woman and has one small child living.

The second child of VI 10 is a girl, VII 45, of good repute and industrious. She marricd a distant cousin, VII 564 , so distant that she did not know of the relationship, and has two small children.

The next two sons of VI 10 were very slow and backward in school. They work at odd jobs at times, but are generally doing nothing. One of them is a very handsome boy.

The last child, VII 48, is a girl who was very "stupid" in school, dresses very flashily and gaudily, and works in a factory. At 19 she is moral. She is of a "silly" type, easily influenced, and may be led to a career of harlotry. This ends the description of the descendants of Ephan and Eliza.

Abe Isaac, by his second consort, Loretta, IV 3, whom he married, had seven children: Avery, Alton, Anson, Augustus, Alma, Alonzo, and Amiel. After Loretta died, Abe Isaac cohabited for a short time with Thelma, IV 4, but had no children by her.

Avery, V 3, was "a laborer; at 30, grand larceny, county jail, 90 days; assault and battery, county jail, 90 days; at 49 , rape on his niece, Sing Sing, 5 years; no property." He was none too industrious and received a pension as a Civil War veteran. He cohabited first with Satie, V 2, a wanderer and a harlot, and had two children by her. The older, VI 13, was a harlot like her mother and has been arrested for intemperance and disorderly conduct. The other, VI 14, a son, has disappeared.

Satie deserted Avery and he then married Geneva, V 4 , and by her had six children, the first dying at birth. While Avery was in State prison for rape on his niece, Geneva was in and out of the poorhouse with her children, and it was in the poorhouse that, at the age of 31 , her bastard child was born. Geneva's family is interesting. Her brother has been in the penitentiary. Her mother was a pauper in the poorhouse at the same time that Geneva and her chikdren were there, making three generations of one family who were being cared for by the town at the same time. There is no doubt that she was feeble-minded. At one time she tried to kill one of her children, and was thereupon sent to a hospital for the insane. She was addicted to the use of laudanum, an overdose of which caused her death.

The first child of Avery and Geneva died in infancy. The second was VI 16, who was 15 when his father was in State prison. At 16 this boy was sent to the penitentiary for petit larceny. At 17 he was a vagrant, wandering here and there. At 18 and again at 20 he was in the poorhouse for one year. At 24 he was sent to the penitentiary for 3 months for petit larceny. At 29 he was sent to State prison for 28 months for assault. At 35 he was in the county jail 1 month for intoxication, and again at 55 he was in the county jail for 10 days for the same offense. He has lost one eye, can neither read nor write, works very seldom, and begs his way wherever he goes. He is mentally defective and should have been in custodial care many years ago. He has cohabited for a long time with a woman, VI 17, who is 10 years older than he, and is a beggar, indescribably filthy, and inentally defective. She has spent most of her life in the poorhouse. At 20 she was there and found her mother and sister there also. She can neither read nor write. She has never had any children.

The third child of Avery and Geneva was a girl, VI 19. She was in the almshouse as a young girl and later was placed in a Children's Home. She was discharged from the latter institution after being there but a short time. As a grown woman she was attractive, neat-appearing, and quiet to a casual observer, but she had a career of harlotry begun early in life and continued after she married (at 26) VI 18, an ignorant, semi-industrious, but wellintentioned man. Soon after the birth of her first child, VII 49, she was divorced on the grounds of adultery. Cohabitation with a vicious criminal, VI 20, followed and by him she had two children, one of whom died in infancy. This man was convicted of burglary and sent to State prison for 1 to 4 years, and during this time VI 19 again became promiscuous in her sex relations. After his discharge from State prison she again consorted with him, then later left him and cohabited with a negro by whon she had one child. At the age of 39, VI 19 was sent to jail for 10 days for using indecent language. Two weeks after she was discharged she was again arrested with her "husband," VI 20, and with Ulysses, V 194, for the same offense and sent this time to the penitentiary for 3 months. At 40 she was arrested for intoxication and sent to jail for 10 days. Even later in life, to one who did not know the real character of VI 19, her appearance, bearing, and behavior indicated a woman of some refinement. She associated with a woman much like herself in appearance but yet of the same low and vicious traits. She placed two of her children, VII 49 and VII 50, in a Children's Home. Her last child (by a negro) was taken by the negro's people at her death, which occurred at 42 .

The history of the two children placed in the Home follows. The boy, VII 49, was placed in the Home at the age 
of 7. The matron recalls him as "slow and with no backbone." At 8 he was sent by a Children's Aid Society to a foster home in the West. The report of this child to the Society reads: "He has given a great deal of trouble, was hard to control, and untruthful. He set fire to a straw stack back of a new barn, nearly causing the loss of the building. He does not do well in school. His lome is a good one and excellently kept. They have adopted a girl of 13 and are well to do." Soon after this report was sent in by the Society's visitor, the adopted girl became pregnant, suspicion turned toward the child's foster parent, and he, in turn, attempted to make the then 12-year-old Juke child admit the responsibility for the girl's condition. Soon after this the boy was transferred to another home, where a childless couple are giving him a good home and trying to do well by him. Here, at the age of 13 , he is in school and doing fair work in grade 4 . Some time ago, when angered by a schoolmate who had taunted him, he stabbed the boy in the arm with a knife. He has little stamina, but has a pleasant disposition, and is now in good physical condition. He has internal strabismus.

VII 50, the half sister of VII 49, was placed in the Children's Home at the age of 5, and at the same time as her brother. She was an attractive child but had internal strabismus like her brother. The matron at the home recalls that there was an almost foolish grin on her face continually. She also was placed in the Middle West and a report to the Children's Society which placed her reads: "She is much like her brother, except that she does well at school and is bright and quick to learn. She is hard to control and inclined to be untruthful, but in spite of her failings is much liked. She has a sweet voice and is being trained by her foster mother, who is musical." She died at the age of 9 of typhoid fever.

VI 22, the fourth child of Avery and Geneva, was born in the poorhouse. When very young she was placed in a Children's Home some distance away from the Juke country. She was adopted, and last reports of her, sent some time ago, say that she is married and has three small children and is doing well. I was not able to find her present address and so could not verify these statements.

The fifth child of Avery, VI 24, was in the poorhouse at the age of 8 for a short period and was then sent to the House of Refuge. At 10 he was placed in a home in Virginia and, after staying there for 7 years, he ran away and has never been heard of since.

The last child of Avery and Geneva was a son, VI 26. He has had little schooling and is only intermittently industrious. He was sent to State prison for 2 years for robbery, and since his discharge from prison has been suspicious and afraid of all strangers. He married a woman of fair repute and had two children by her, one of whom died. He deserted her for a harlot and the wife then became a harlot and has been in houses of prostitution. Their child, VII 54, now a boy of 11, has been left here and there by the mother and recently was arrested with VI 229, a degenerate, who was training him to beg.

Alton, $\mathrm{V} 6$, is a brother of Avery and son of Abe Isaac and Loretta. His record is given by Dugdale as follows: "Laborer and canaller; at 15, mother dies; 17, poorhouse, bound out; 20 , threat to kill, county jail; 22, burglary, third degree, Sing Sing, 3 years; 24 , cohabits with $X$ (Mary Ann); now reformed; intemperate; rather indus- trious." V 6 acquired a 10 -acre farm and lived on the place. As he grew older he became less industrious. He died at the age of 71 , of uremic coma.

Alton's first consort, Mary Ann, V 5, a harlot, died of childbirth after she had been living with Alton for a short time. He then cohabited with her sister Goldie, V7. She could neither read nor write, was lazy, and had been a harlot before she cohabited with Alton. She was a member of a family that is as distinctly criminal and defective as the Jukes, although not so numerous. She had lived with Alton for 13 years when she died. Alton then secured Ruth Ann, V 8, as a consort and lived with her until his death. She is now an old woman, worn out physically, shrewish, and ignorant. She is living with a man to whom she is not married and is very poor.

Anson, V 10, the third legitimate child of Abe Isaac, was "laborer; at 12, petit larceny, county jail, 30 days; at 14, mother dies, poorhouse, one year; 21, petit larceny, county jail, 30 days; grand larceny, Sing Sing, 3 years; 34 , county jail, 30 days; 36 , county jail, 30 days." He was intemperate, a semi-industrious farm-laborer, and always poor. He never acquired any property. He deserted his first wife, Leah Eliza, V 9, for her sister, Sibyl, V 11. He had two children by the latter, a boy and a girl, who were placed in an Orphans' Home when very young and of whom all trace is lost. In his later years Anson was tubercular. Seemingly he experienced no arrest during this period; at least there are no records of such. He died of tuberculosis at the age of 57 .

The fourth legitimate child of Abe Isaac was Augustus, $\mathrm{V}$ 13. Dugdale gives his record as follows: "At 12, mother dies, poorhouse, 4 years; 17 , county jail; 18 , petit larceny, county jail, 60 days; 22, petit larceny, 30 days; loafer; syphilis; no property; laborer." He was in the Civil War, and soon after its close he became blind, whether through syphilis acquired in the war, or through burning of his eyes by acid (as common report says) I do not know. However, for many years he has received a pension of $\$ 30$ a month on account of his blindness. With the help of his second consort, Panna, V 14, an ignorant but industrious woman, he has acquired real estate that is worth about $\$ 600$ and upon which he now lives. He is naturally indolent and is intemperate. He has an emotional makeup, and, when telling how well his harlot-consort Panna takes care of him, he weeps and shows other hypocritical behavior suitable to the occasion. He has quite a temper which can be easily aroused.

Mame, V 12, the first consort of Augustus, was a syphilitic harlot who deserted her husband for Augustus and then left the latter for another. The second consort of Augustus, Panna, is "simple." She does housework in "town" and most of her wages go to support her nephew, an unindustrious fellow with a family. Panna has a consort, also quite aged, who lives with her in the home of Augustus. Panna owns a horse and wagon and the consort is "her driver," and this interesting pair may be seen almost daily in the streets of $Z$. Augustus has no known descendants.

Alma, V 15, was the fifth legitimate child of Abe Isaac. At 8 , when her mother died, she went to the poorhouse, where she remained 4 years. She became a harlot after this and acquired syphilis. She married Roswell, V 16, a rather industrious man and a recent immigrant, who was later blown up in a quarry accident and killed. Alma 
was intemperate, never acquired any property, and died at the age of 30 , leaving three young children.

The oldest, VI 30, was 10 when her parents died. At 14 she was raped by her uncle Avery, who spent 5 years in State prison for the crime. Nothing more is known of the child after this.

VI 31, the sister of VI 30, was 5 years of age when her parents died. She was a dwarf, making the second that has appeared in the Juke family. At 8 year's slie was sent to the House of Refuge as a disorderly child. She grew up to be industrious, but was a thief and was immoral. At 19 she added to these vices, and became intemperate, yet she seemed to realize that she was not doing as the House of Refuge people wanted her to do, since she wrote to the institution telling them that she was trying to do better. At 20, she was indentured for 3 years at the rate of $\$ 10$ a year. At 23 , when she left this place, she seems to have lost her identity, as no trace of her now exists. Her younger brother, VI 32, was a laborer in the cement mines and died at the age of 25 .

Alonzo, V 17, the sixth legitimate child of Abe Isaac, was a "laborer; at 7 , mother dies, poorhouse, 4 years; 16 , assault and battery, county jail; 17 , robbery, first degree, Albany penitentiary, 10 years; 26, county jail; loafer; single." He was very intemperate and died of dropsy at the age of 30 .

The last child of Abe Isaac was Amiel, V 19. He was a "laborer; at 4, mother dies; poorhouse, 4 years; 24 , poorhouse, 1 year; 26 , wife dies; town burial; intemperate; no property." He is now an industrious laborer and well liked by the people for whom he works. He is very deaf, has syphilis, has a wandering nature and a quiet disposition. He has always been very poor. His first wife, Lettie, V 18, after having two children, died of syphilis and was buried by the town. Amiel then cohabited with Sally Ann, V 20, an industrious but garrulous, ignorant, and shrewish woman of no morals. This couple lived in a three-room hovel on a mountain side, and had 11 children.

The first child of Amiel and Sally, VI 36, was an ignorant, untrained fellow, who ran a house of prostitution and was sent to prison for this.

The second, a girl, died in infancy.

The third, VI 38, can read and write, but is lazy and spends most of his time hunting and fishing. He is very poor and lives in a hovel in the woods with his wife, VI 353, also a descendant of Ada. This woman is neat and industrious but ignorant, being unable to read and write. Her mother died while she was yet young, hence she was forced to do housework for a living and so never attended school. The couple have two small children, both of whom are girls.

The fourth child of Aniel, VI 39, is unindustrious, inefficient, and a "farm hand" 30 years of age. He has a quiet disposition and spends most of his time hunting and fishing.

His brother, VI 40, did average work in school and is active and energetic-in summer working as a farm hand and saving his money, in winter hunting and selling skins. He has a striking personality and is careful in dress.

The next two children of Amiel died in infancy.
Then came VI 43, a boy of 18 , retarded in school, mentally inactive, quiet and shy in behavior. He spends most of his time liunting and fishing.

The next clild was a girl, VI 44, who was accidentally burned to death in a bonfire at the age of 7 .

The tenth child, VI 45, attended school fairly regularly until she was 17 and, at that time, she was in the third grade. She was untidy and careless in her appearance, was shy, and never associated with anyone outside of her family. She was reputed chaste to the age of 17 , when she married.

The last child of Amiel, VI 47, was still in the first grade in school at the age of 12 . He is mentally slow and has a shy, retiring nature. In Dugdale's book, chart 1, generation 5, line 13 , it reads: "Laborer; at 2, mother died; poorhouse, 4 years; unmarried." Search failed to find this individual, and two of his brothers, Amiel and Augustus, say that they had no brother of that description. $\mathrm{He}$ is therefore left out of this history. This ends the description of the descendants of Abe Isaac.

Abe Isaac's eldest sister, the daughter of Alexander and Beatrice, was Alice, IV 5. She was "somewhat industrious; temperate; at 34, outdoor relief, 1 year; 43 , outdoor relief, 1 year; 52 , husband in State prison; became a prostitute during that period; 57 , outdoor relief, 1 year; 63 , outdoor relief, 7 years; died 1871." Alice married Stillman, IV 6, "shoemaker; at 30, forgery, State prison, 2 years, where he learned shoemaking; 35 outdoor relief, 1 year; 44, outdoor relief, 1 year; 59 , outdoor relief, 1 year; 64 , outdoor relief, 9 years; was intemperate in former times, but not so now; real and write." This couple was always poor. They had ten children, only eight of whom were noted and described by Dugdale. Their children were: Al, Abel, Alva, Allen, Alice Ella, Alberta, Agnes, Adelaide, Annetta, and Amalia.

The oldest, Al, V 21, born in 1826, was a boatman on the canal. He never attended school, could neither read nor write, was very intemperate, and married a cousin, Naomi, V 213, a descendant of Bell Juke, and a basketmaker of good repute but ignorant. Although $\mathrm{Al}$ was a good worker he made but small wages, and the family received help from the town for many years. At 38 Al went to war and, during this period the family received town help. After he returned this help continued. He never acquired any property and died at the age of 84 . Naomi is still living and is mentally slow and inactive.

$\mathrm{Al}$ and Naomi had 12 children, only 4 of whom survived infancy. The oldest, VI 49 , is an ignorant, semi-industrious woman of fair repute, who has married twice and is now living. She had no children. The second child of Naomi to grow up, VI 53, was uncouth, illiterate, industrious but untrained, and consequently inefficient. She was married and had 3 children, 2 of whom died in infancy; the other, VII 60 , who became a machinist, was mentally slow and had little ambition. VI 53 died recently from the cffects of a fall. The third child of $\mathrm{Al}$ who grew up was VI 55. It is known only that lie died at the age of 28 . The fourth child of $\mathrm{Al}$ is VI 57, an ignorant but industrious fellow of a quiet.nature, who has saved his money and acquired a little property. He married a woman who before her marriage was, and since has been, a harlot. They have no children. At 51 this man committed rape on a child 13 years of age and was arrested on the charge, but the case was dropped in court. 
Abel, V 23, the second child of Alice and Stillman, was a "laborer; at 38, outdoor relief, 1 year; 39 , abandoned his wife; 40, disorderly, county jail, 10 days; somewhat industrious; intemperate, can not read or write; no property." Abel married Honora, V 22, and later deserted her, after having had two stillborn children by her.

Alva, V 24, the third child of Alice, was a "carpenter"; 1857 , outdoor relief, 1 year; good citizen; industrious; read and write; acquired house; lost it." In his later years he was very poor and died at the age of 87 of apoplexy. Alva's wife was Dorothea, IV 152, a cousin, of Delia blood. She was a woman of good repute, industrious and temperate, but very ignorant. She never attended school. After marriage she received poor relief at various times. They had 7 children, 4 girls and 3 boys.

The oldest of these, VI 65, was born in 1845 . She was of good repute always, industrious, and spoken of as "fairly intelligent." She married VI 66, a carpenter, a man of little education, but industrious and a fair citizen; who has recently become invalided by a stroke of paralysis. They had three children.

The first, VII 64 , a woman of fair intelligence, some schooling, industrious and neat, married an industrious but intemperate man, VII 63 , who is cross and abusive when intoxicated. They have moved to a large city away from the Juke region. He makes good wages and they have a comfortable home. They have five children; four boys, of whom one died of diphtheria at the age of 13 , one is a stenographer in an office and doing well, and two are industrious but intemperate and have little ambition in life; and one girl who died of diphtheria at the age of 5 .

The other two children of this couple, VI 65 and VI 66 , were boys, eapable in school, of good behavior, and industrious. Both are dead; one died of diphtheria at the age of 15 , the other was drowned in the Johnstown flood.

The second child of Alva and Dorothea, VI 67, married when young an intemperate and ignorant but industrious man, who is a laborer. She had 5 children by him, 3 dying in infancy. She died at the age of 33 of typhoid fever. Her oldest child, VII 68, now 34, is an industrious girl of fair repute, who keeps herself neat and her home comfortable. She is mildly intemperate. Her husband, a laborer, is intemperate, but otherwise is a good citizen. She has no children. Her brother, VII 69, is a laborer with a fair education, but intemperate at times. This branch of the family lived in a large city some distance from the Juke region.

The third child of Alva and Dorothea, VI 69, had little education and married a laboring man when young. The family has always been poor and nomadic, never remaining long in one place.

The oldest child of this pair is VII 74, who has tried hard to bring up well her many children. She married an ignorant and mentally defective man. By him she had eleven children to whose support he has not contributed. At one time he was in a hospital for tuberculosis, where he remained for a season. He is continually intoxicated and abuses his wife and children. The fanily has received poor relief from the town and also private aid for the past seven years.

The oldest of these children, a girl, VIII 36, was retarded in school and mentally slow. She is neat and industrious, recently married, and tries hard to get along in her new home. Her husband is a laborer and receives small wages and the two have received private aid in the past year. The second of these children, VIII 38, was very poor in her school work and is mentally defective. After leaving school she entered a cigar factory. At 21 she became pregnant and forced the man to marry her; the child was born later, and soon after this the man was arrested for burglary and sent to jail for 4 months, a longer sentence not being given, as the wife was again pregnant. These two have received a great deal of help publicly and privately. The husband is a foreigner, incapable, and untrained. The third child is VIII 40, an epileptic girl of 20. Fainting spells began at the age of 14 and soon developed into true epileptic seizures. She is now much deteriorated mentally. She married young and has one child, IX 1, now aged 2 years. This child is anemic and is paralyzed from the hips down. In 1913 the father was sick and unable to work and was given aid by the city. The mother and child were in the hospital and were supported there by the public. The fourth child, VIII 41, was retarded two years in school. She worked in a cigar factory after leaving school and did much to support her family. She has recently married. The fifth child, VIII 42, died in infancy. The sixth, VIII 43, now 15 , attends school and is now three year's retarded in her work. She is slow mentally and is thin and underfed in appearance. The seventh child, VIII 44, is now, at the age of 10 , in grade 2 in school, attends school irregularly, and gives the appearance of being underfed. The eighth child died, and the last three children of this fraternity are still young.

VII 74 has four brothers, all of whom are laborers, but of whom little is known further than that they are wanderers.

The fourth child of the consanguineous mating of Alva and Dorothea is VI 71. He was born in 1858, never attended school, works at times as a wood-chopper or as a farm laborer, is intemperate, deceitful, a liar, and is reputed to be a thief but has never been caught. He married an ignorant, sloventy, but semi-industrious woman, VI 72 ; the pair live in a hovel and are very poor. They had 6 children.

The first, VII 80, can read and write a little. At 19 she became pregnant by a man 20 years older than herself, and married him before the birth of their child. She is as neat in her appearance as her poverty will allow, is a thief, and will steal whatever she can lay her hands on. Her husband, also a thief, does little to support her, spends most of his time hunting and fishing, and is very intemperate. They live in a shack in the mountains.

This pair had five children in all. The oldest, VIII 49, a boy of 12 , is feeble-minded, and, consequently, very much retarded in school. He is a thief. His sister, VIII 50, is also feeble-minded and is very much like her brother. The other three children are still young.

The second child of VI 71 is also a girl, VII 82 . She is intemperate. While still a child she cohabited with one man and was promiscuous in her sex relations. At 16 she had a bastard child. She has acquired syphilis and has been sent to jail for disorderly conduct and prostitution. When her child was 6 years of age it was placed in a Children's Home and the mother left the Juke country and led an immoral life elsewhere. This bastard child, VIII 54 , is "quiet, ill-mannered, fond of dress, and mentally slow." At 6 she was placed in a Children's Home, where it was discovered that she had syphilis. She was sent to a hos- 
pital for treatment for six months, and one year after her admission to the Home was placed into a good fanily in the Middle West, the foster parents not being informed of the child's infectious disease.

The next child of VI 71 was a boy, VII 84, "stupid in school," unindustrious, but with a taste for "tinkeling." He is interested in motorcycle racing and has made long trips on his machine. He was arrested recently for using his machine in violation of traffic laws.

The next child of VI 71 died in infancy. The next two, VII 86 and VII 87 , both have a low grade of intelligence and are incapable of learning in school. The older one, now 18, has a specch defect. He is a "laborer," but very seldom works.

The fifth child of Alva and Dorothea, VI 73, is called a "bad man," and has been arrested for petit larceny and sent to the penitentiary for 3 months. He is married and has had 5 children; 2 are dead and 3 living. His present address is not known.

The sixth child of Alva, VI 75, is reputed to have left the country and gone to "Texas," merely a Juke name for a distant country.

The last in this family group is VI 76, who married an intemperate but industrious laboring man who has saved a little money, VI 77, brother to VII 63 (page 8), whose father was in the poorhouse for 11 years. Little is known of VI 76. She lived in a large city some distance from the Juke country, and died many years ago, leaving 5 children. The oldest, VII 93, was drowned at the age of 15 in the same accident in which IV 28 and his family lost their lives. The next two girls have married well. The last two, boys, are not mentally active, but are steady, industrious laborers.

The fourth child of Alice and Stillman was Allen, V 26. In Dugdale's chart I, generation 5 , Allen is not mentioned or described. He can read and write and at times has been a "pettifog lawyer." He is semi-industrious and a carpenter by trade, but will work also at ice-cutting or as a laborer. He was a soldier in the Civil War and now receives a pension. He owns a small house and lot in one of the poorer sections of $Z$, is a wanderer, and has traveled over a great part of the United States. Nothing is known of his first consort, Selinda, V 25. Allen had 4 children by Selinda, 3 girls and 1 boy.

The oldest, VI 78, was sent to a Children's Home at the age of 9 after her mother's death. She remained there 2 months. At 19 she was arrested for petit larceny and sent to a Church Home. She soon escaped from this institution and became a prostitute. She can read and write, is now employed at housework, and is immoral.

The next girl, VI 79, was in the Children's Home at the age of 6 for a few months. She married at 18, had two children, and has left the Juke country.

The third child of Allen, VI 81, was married at 16 to a carpenter who is industrious, but mentally slow. He is a steady workman, but is semi-skilled and so receives but low wages, and the family is poor. They have three children, two of whom are now in school and, although in good physical condition, are mentally slow and incapable of acquiring the most primary school knowledge. The older, a girl, VII 102, now 9, is in grade 2 and has great difficulty in learning the pronunciation of words and can not learn to add. The younger, VII 103, a boy of 6 , can not recognize figures nor learn to add.
'The fourth ehild of Allen, VI 83, was sent at 15 to the House of Refuge for stealing. At 20 he was sent to the county jail for 6 months and fined $\$ 50$ for assault and battery. At 27 , he, with two other looys, one 15 and one 18, "unlawfully entered a barn," were arresterl, and at this writing are awaiting sentence in jail. VI 8.3 has lad little schooling, is reported to have been a poor pupil, is a wanderer, and works here and there at orlel jobs.

After Selinda died, Allen secured his present consort, Salva, V 27, a Polish woman, mentally defective, slow, uncouth, and untrained. S'alva harl a bastard girl just before she went to live with Allen. Allen and Salva liave 4 children, all of whom are boys, mentally 3 to 4 years retarded, lazy, and without ambition to learn in school. The oldest, VI 84 , now 22, is a laborer, working at odd jobs. The youngest is 9 year's of age. Allen, now 73 , is a galrulous man with a love of telling about his wonderful personality. He is poor and lives in filth.

Alice Ella, V 28, the fifth child of Alice and Stillman, was a harlot and cohabited with Selig, V 29, on his canal boat. She became pregnant by him and married him just previous to the birth of the child. He was considered well to clo and owned real estate, shares in a powder-mill, and other property. For many years he ran a canal-boat on the Hudson Rivel. Alice Ella and Selig went away from the Juke region and settled in a community some hundred miles distant. He died in 1900 at the age of 70 . Alice Ella, as an old woman of 70 , was a quiet, rather refined, frugal lady. She died in 1910 as the result of an accident.

The son of Alice Ella and Selig, VI 89, opened a drygoods store, and has done well financially. He is now reputed to be worth $\$ 50,000$. His neighbors speak of him as retiring, unwilling to enter into social life with them, and not interested in books. He married a good, intellectual woman, VI 88, and had 3 boys and 1 girl. The daughter, VII 106, was conscientious and plodding in her school work, and later taught in a kindergarten. After some years of teaching she had a nervous breakdown, stopped teaching, and married. She was considered somewhat opinionated. The oldest boy, VII 107, could not learn easily in school, was stublorn and opinionated in his ways, but is now working steadily. The third, VII 108, also backward and stubborn, left school in the first year of high school, started a business of his own, but failed, and is now working under direction and doing well. The last, VII 109 , born 1889 , is petty in his exactness, the "smartest" of this fraternity, and is now attending college.

Alberta, V 31, the sixth child of Alice, could read but not write. As a young girl she was a harlot. At 17 she married Lincoln, V 30 , who seems to have deserted hel soon afterwards. She then cohabited with Darius, IV 126 , of Delia blood, a mentally defective man, licentious and criminal, but a good worker, who, at the age of 62 , died in the poorhouse, where he went following alcoholic debauches. Darius and Alberta received poor relief interinittently. At 32 she was sent to the county jail for 10 days for vagrancy. She was intemperate and at one time ran a brothel. After Darius deserted hel, she cohabited with Ray, $V 32$, until her death from paralysis in 1900 . 
Alberta had two children, both of whom were girls. The first, VI 92 , born in 1850 , was in the poorhouse at 15 with her younger sister, then 7 years old. They remained in the poorhouse a year and soon after this the younger sister, VI 93, was accidentally shot to death by a returned soldier while he was cleaning a gun.

The remaining sister, soon after this, married a newspaper man, who was industrious, intelligent, and of good principles. She had three children. She became an alcoholic in middle life and died of the effects of her excesses.

Her oldest child, VII 111, reached the second year in ligh school, when she stopped to go to work. She always bore a good reputation, is married, and has gone away from the Juke region.

The second child, VII 112, was considered an average child in school. She had good morals as a young girl, but married an inefficient and lazy man, an alcoholic. His habits of intemperance soon led her to drinking, a habit easy for her to acquire when her mother's tendencies in that respect are recalled. She drank more and more, until she finally became paralyzed from the effects and died of neglect. Her father, VI 91, then took her two young boys to rear. One, now 10 , is retarded at the present time, while the other, aged 8 , has not yet entered school. The father of these has been arrested for the non-support of the mother many times, but, as he would not work, nothing could be done. After the death of his wife he disappeared.

The last child of VI 91 and VI 92 is VII 114, an industrious, capable man holding a responsible position in a printing-office. He is married, but has no children.

The seventh child of Alice is Agnes, $Y$ 33. She attended school and reached the first grade in the high school when she stopped. At this time she was a harlot. She was married at 18 to Leo, V 34. Leo was a photographer and did well in his business, but his continued alcoholism ruined him physically, financially, and morally. He became shiftless and lazy, and finally went to a Soldiers' Home, where he recently died.

Agnes had five legitimate children. The first, VI 95, was not industrious and was addicted to drink; he married a harlot, later deserted her and went West, and is now in California. The second child died in infancy. The third, VI 97, was a laborer, ignorant, intemperate, and not inclincd to work. He is married. The fourth child of Agnes died in infancy. The fifth and last child, VI 100, now 29, has average intelligence, is personally neat, and bears a good reputation. She has recently married, but has no children.

Adelaide, V 35, the eighth child of Alice and Stillman, had a roving disposition. At one time she was an actress in a traveling show. She was a harlot before marriage. She had epilepsy. Her husband, Lester, V 36, can neither read nor write. He was a teamster and worked regularly for the same man for 32 years. He was formerly alcoholic and has been arrested several times for drunkenness. He is a member of a family noted for its viciousness, intemperance, and degeneracy. His brother was Hendrick, V 71, who also married into Ada blood. Lester is now living, and is 85 years of age. Several years ago he lost his right leg, as it was necessary to amputate it following gangrene. Iester married Adelaide in 1854, when she was
21. She died at the age of 57 of tuberculosis. Adelaide had nine children.

The first, VI 103, born 1855, is an ignorant woman, but very kindhearted when anyone is sick. At one time she joined a traveling circus. She is very neurotic and has migraine and, when these headaches become severe, it is said that "she goes completely out of her head." In her periods of nervous excitation she shows an ugly disposition and continually finds fault and quarrels with her neighbors. Her husband, VI 102, was at one time part owner of a traveling circus, probably the one in which she traveled. He was later a blacksmith and worked steadily at his trade for many years. He was very intemperate formerly, but has acquired a house and land and is considered a good citizen. They had three children.

The first, VII 117, born 1875, did the usual work of the public schools. As a young fellow he committed incest with his epileptic sister, VII 118. He started in business by himself, but, as he was not clever or foresighted, others took advantage of him by unfair means and he failed several times, but he still persevered. He himself was tricky and had no ethical or moral sense. His first wife, VII 116, had attended school, but was mentally defective. Her father was considered normal mentally, but her mother and several sisters were feeble-minded. She became a harlot after marriage and divorced her husband, as he too was promiscuous in his sex relations and consorted with low women. He afterwards married his first cousin, VII 124. He was killed in a railroad accident during the course of this investigation. By his first wife VII 117 has had three children: a boy, now 18, VIII 57, who was incapable of carrying on high-school work but did well in the United States Navy; a boy of 14, observant and capable when he wants to be, but usually slow and sleepy in school, and sly and sullen at times; and a girl of 9, slow in actions and thought, but who "can get there if given time." There were no children by the last marriage.

The second child of VI 102 and VI 103 was a girl, VII 118. While still young she developed epilepsy and with it mental deterioration and ideas that she was being talked about. She would then become excited and try to injure others. She has committed incest with her brother and also her uncle, VI 116. At 17 she was committed to a hospital for the insane for attempting homicide and threatening suicide. Here she died at the age of 31 .

The third and last child of VI 102 died while a young girl.

The second child of Adelaide died in infancy.

The third child, VI 105, born 1862, was quiet and refined in her manner when a girl. She became addicted to the use of drugs, and recently has become nervous and shows an excitable temperament. For many years she was a seamstress and was industrious and respected in the community. At 40 she married a sober, industrious laboring man and the two have a neat home in a respectable part of the city of $Z$. They have one child, a girl, VII 120, nervous, never quiet for a moment, unable to concentrate her attention or to retain facts. She is now 12 years of age and does poorly in school.

The fourth child of Adelaide died in infancy.

The fifth, VI 109, is unindustrious and unprincipled and an alcoholic. He married VI 108, concerning whom I have no data, and had five children, of whom one died in infancy. After the death of his wife, he placed the two young children who were then at home in a Children's Institution, and 
has been living with another woman, by whom he has one small child. He is spoken of as "a bad sort of a 111an," and has never been liked by his neighbors.

His first child, VII 122, was placed in a Children's Home at the age of 9 . Here she remained for a time, and then went to live with her aunt, VI 103. At 20 she became pregnant and married the father of her unborn child. For the first 9 months after the baby was born the family tramped the roads looking for work. Unsuccessful in this, the mother and child went to the almshouse for a month; while there she had her husband arrested for non-support. The case was dropped after he had secured work on the railroad, and since that period the family has been getting along well. She is a capable seamstress, has had little schooling, and is quick-tempered. She was accidentally shot recently by her younger brother, VII 126, and was injured in the back in such a way that she has become paralyzed from the hips down.

The second child of VI 109 died in infancy.

The third, VII 124, was slow but steady-going in school and was careful and attractive. At 18 she married her cousin, VII 117.

The two youngest boys in this family, VII 125 and VII 126, were placed in a Children's Home when young and have been here and there. The older is now with foster parents and is reported as doing well, while the younger is now with his sister, who was accidentally shot by him.

The sixth child of Adelaide, VI 111, is a woman of good morals, orderly, and industrious. She has a quiet disposition and has little to do with her neighbors. She is ealled "queer and eccentric" in many things she does. She married an industrious, capable man and moved away from the Juke region to a nearby city, where they are doing well.

Their oldest child, VII 129, is a careful, quict-appearing woman of good repute, 27 years of age, who did the grade work in school, married, and now has four children, the oldest of whom is very keen in her school work.

The second child of VI 111 is a boy with good artistic sense, which is being especially trained in a trade school. While very incapable in other subjects he is being encoulaged in the one thing he can do well.

The last child of VI 111 who lived is a neat, wellbehaved girl of 14 , doing well in school, except in arithmetic.

Adelaide's seventh child died in infancy, while the eighth, VI 114, is an active, energetic fellow who moved away from the Juke region and its associations and went to a large city, where he is sporting editor of a daily newspaper and is doing well. He is married and has one smakt child, VII 133, who does her school work easily.

The last in this family, VI 116, when a boy of 16 or 17 , committed incest with his niece, VII 118, of the same age. When he grew up he became a laborer and is an ignorant, wandering, inefficient fellow. He is married, but has no children.

Annetta, V 37, was the ninth child of Alice and Stillman. She has had little education, but is considered of "fail intelligence," though she has been intemperate. She married Hemid, V 38 . He was industrious, but untrained, and so had a hard time to get along financially, and for a short time following their marriage they received poor relief. Hemid was a "good citizen," ignorant, but well-meaning. They had eleven children.
Annetta's first child, VI 119, is an industrious nechanic of good reputation, who has saved his money. He married and had two children, both of whom died at birth. He moved away from the Juke country.

The second child of Annetta died in infancy.

The third, VI 121, was chaste, intelligent, and reputable. She married an industrious man much like herself socially and mentally and had four children. These four are all intelligent, active, and of good repute in the community.

The fourth child of Annetta, VI 124, married and had one son, but was deserted soon after marriage. Since then she has supported herself and child at anything she can find to do. She and her soll, now 25 years of age, have moved away from the Juke land and are living in a large city. The son is a sliftless fellow and is but semiskilled.

The fifth child of Annetta died young.

The sixth, VI 126, moved away from the Juke region, following his brother's example, and has become a steady, industrious man. At 21 he married a girl of 16 who is now careful, industrious, and capable. They had three children, a well-behaved boy now 12 , doing well in school, and two smaller children.

The next child of Annetta, VI 128, did not migrate from the Juke region when his two brothers left, but remained there. He is a laborer and works at whatever coines his way. He married an ignorant and inefficient woman, a harlot, VI 129, and has four children, three of whom are each retarded 3 years in school.

The next three children of Annetta died in infancy.

The last child of this group, V'I 133, born in 1871, was of good repute and of fair intelligence. She married, when young, an industlious man, who is a good citizen, and has three children, who are all capable in school and of good repute.

Amalia, V 39, was a sister of Annetta, and last child of Alice and Stillman. She "had brains enough but used them in the wrong way." She was ignorant, for many years a harlot, and intemperate. Her first husband was a cousin, Douglas, IV 131, an ignorant fellow, a teamster, who was killed by his brother in a drunken biawl. Amalia and Douglas received poor relief for many years. After his death she lived with Royal, V 40, a climinal, by whom she had one illegitimate child, VI 144. She is now dead.

Anulia's first child, VI 136, has gone away from the Juke region. He became a locomotive engineer, married, and is a good citizen. He has one girl recently married, but of whom no trace could be found.

The second child died young.

The third, VI 138, is mentally less active than the other's, but has always been industrious and reputable, and occupies a responsible position with a manufacturing firm. He is married and has two children. The older', a son, VII 156 , now 40 , is an industrious, capable man of good repute. He is married and has one child, now 12, orderly, attractive, and capable in school. VII 157, aged 35, is an intelligent and industrious woman of good repute, a seamstress.

Amalia's fourth child is VI 140, who is persevering and energetic. He developed a good business and acquired property. His business was almost destroyed by fire one Sunday morning, but early the following day he hired horses to replace his burned ones, and was engaged in business as usual. Morally he is of a different make-up. 
He is reputed to have lived with his "wife" and had all 3 children before legitmizing them by marriage. His wife, VI 141, is shrewish, a fault-finder and ignorant, but of good mentality. They have three children who grew up. The first, VII 158, aged 35, holds a responsible position as a bookkeeper in a large corporation; the second, VII 159, is industrious and quite musical, but intemperate; while the thircl is an intelligent, industrious woman of good repute. The latter was formerly a school teacher and is now well married.

Amalia's last legitimate child, VI 142, a woman of fair intelligence and repute, married and has four children. The first, VII 164, is married and has gone away from the Juke region. The second, VII 167, an industrious, steady fellow, is married and has 2 children; one doing well in school, and the other still young. I have no data in regard to the last two children of this fraternity.

Amalia's last child, VI 144, the bastard, is quiet in his actions and a steady-going man, but unlettererl. He runs an express wagon for himself. He is married, but has no children.

Albert, IV 7, was the third child of Alexander and Beatrice. He was born in 1807 , kept a tavern and brothel, was a cautious thief, and was never caught. He received poor relief for many years. He married Ruth, IV 8. She was arrested twice for keeping a brothel, but was not convicted at either time. They had ten children, and this group of the Jukes is characteristically criminal.

The first of the children, Abraham, V 41, was a "sailor; at 19 , burglary with his brother 12 years old; 41 , county jail, safe keeping, 7 days; unmarried." He died at the age of 50 .

The second, Adeline, $\mathrm{V} 43$, is described by Dugdale as follows: "Harlot; at 21, had a bastard girl; married; 25, kept a brothel, fined; 30, safe keeping, county jail, 7 days; intemperate; 33, cher in 1863 of the effects of an abortion." She married Hanford, V 42, whose record was: "1855, brothel; 1858 , disorderly house, fined; 1859 , breach of the peace, county jail, 15 days; dead; probably impotent."

After Hanford's death, Adeline lived with Francis, V 44, a criminal man. Adeline had four bastard children.

The first, VI 146, at 14, was with child by her uncle. At 15 she was in the county jail, and at 17 married. Further than this data of Dugdale's, I could secure no information about this girl.

Adeline's next two children died in infancy.

The last, VI 149, was sent, at 15, to the House of Refuge for grand larceny. At 23 he was sent to State prison for 3 year's for burglary along with his uncle Adam, V 47. He was an ignorant, vicious young fellow. Since his term in State prison nothing has been heard of him.

Adam, V 47, born 1823, is described by Dugdale as follows: "Laborer; at 12, burglary; 17, burglary, State prison, 2 years; 22, breach of peace, Sing Sing, 2 years; 24 , burglary, third degree, Sing Sing, 3 years; has been 9 times in prison, and served 14 years; learned iron-rolling there; reformed; now rents a quarry; doing well." He could neither read nor write, was intemperate, strong physically, and on little provocation would fight with anyone. Adam's criminal record subsequent to the period at which Dugdale studied him is interesting. At 54 he was in State prison for 3 years for burglary. At 66 he was sent to State prison for 2 years and 6 months for grand larceny, and at 69 was again in State prison for burglary. A conservative estimate of the cost to the State for the arrests, trials, and care of this one man is $\$ 6,000$. This does not include the amount of his depredations, which can never be known.

Adlam's first wife, a woman of reputable parents, was Sue, V 45, who, taking their child with her, left the country when she discovered that her husband was a criminal. Rumor has it that she went West and became a well-known social worker in a certain large city. His second wife was Pauline, V 46, whom he deserted. In 1880 he took his third companion from the poorhouse, but left her shortly afterward. Adam then lived with Sarah Jane, V 48, by whom he had three children. Adam died in the poorhouse at the age of 88 .

Sarah Jane, Adam's last consort, has a quiet disposition, and is now a semi-refined, church-going woman. After Adam left her, about 1900, she and her children went to live with another man with whom she still cohabits.

Adam's three children show most interesting traits, in view of their environment and heredity. They lived and grew up 100 miles away from the ancestral breeding-spot of the Jukes. The oldest child of Adam and Sarah Jane, VI 151, was born in 1881. In the low grades in school he was considered a little below the average of the class. At 11 , he, with other boys, was arrested for stealing shoes, etc., from stands in the street. The same year that his father was sent to State prison for robbery, the son was sent to the State Industrial School for Boys. Here he showed hittle aptitude for books, but was very fond of music. He instigated a feeble-minded boy of low grade to set fire to the institution buildings with the hope of escape during the excitement following. The plot failed and he was sent to State prison for from 4 to 7 years for burning a public building. He died of tuberculosis in State prison while serving this sentence.

VI 152, the brother of the above-described man, and four years younger than he, is recalled by his primaryschool teachers as "a very beautiful child." He was below average in his studies, very pleasant to one's face but treacherous otherwise. At 10 he was sent to the Children's Home for truancy. He immediately ran away and returned to his old haunts. At 11 incorrigibility sent him to the State Industrial School for Boys, where his older brother awaited him. In 1902, aged 17 , he was paroled from this institution to his stepfather. In the following year he was fined $\$ 3$ for breach of the peace, and for burglary was in the county jail 2 months. At 19 he was sent to the county jail for a year for burglary. At 21 he served 2 months in the county jail for burglary. At 22 he was convicted of an assault with intent to kill and a sentence of from 10 to 15 year's in State prison was given him. Here again his older brother preceded him. He died of tuberculosis in State prison at the age of 27.

In strong contrast to these two boys is their sister, VI 153. Born in 1887, she has grown up a keen, levelheadecl girl. She has retained her chastity in spite of the low moral tone of the factories in which she worked and of those who wished to take advantage of her. She is now well married and has one child. The sister of criminal brothers, she has remained chaste, under environmental conditions which would naturally produce prostitution. 
Adelbert, V 49, the fourth child of Albert and Ruth, was sent to the county jail for 30 days for assault and battery when lie was 20 years of age. At 22 he was convicted of burglary in the third degree and sent to State prison for 2 years. At 31 he was reported as reformed, owning a 40-acre farm and quarry worth $\$ 5,000$. He is recalled by old residents as a man below par inentally and not liked by the better sort of people. He was slightly intemperate at times, and would get mixed up in petty brawls. His wife, Lu Ethel, V 50, lived with a nan before her marriage to Adelbert. She could read and write, was industrious and temperate, and inherited property. They had only one child, VI 155, a girl of good repute and considered intelligent. Later she married an intemperate, lazy ne'er-do-well, VI 156, who deserted her before her last child was born. She had four children, only two of whom are living: a boy, VII 174, industrious and capable, who is married, and a girl, VII 177, of whom nothing is known.

Athena, V 51, was the fifth child of Albert and Ruth. Dugdale's record of her follows: "Harlot; at 20, county jail, 9 days; 22 , vagrant, county jail, 2 days; 23 , forfeits bail; outdoor relief, 1 year; 25 , married; 31 , safe-keeping, county jail, 7 days; outdoor relief, 1 year; intemperate; can not read or write." She was sub-normal mentally and an immoral woman. She was kind-hearted and would do anything for anyone of whom she was fond. Though a hard worker, she spent what she earned in drink, hence was always poor. She died of pneumonia and tuberculosis at the age of 62 .

Her husband, Levi, V 52, was a canaller and quarryman. At 25, he was sent to Sing Sing for 1 year for larceny. He is a man of low mentality, but has always worked hard; also he has been a very heavy drinker and his wages have gone for this. He received a great deal of poor relief, but records do not show this. Athena and Levi had six children.

The first, VI 157, was a mentally weak woman, who is indolent and inefficient. As a child she had "fits." She was a harlot before she married her cousin, VI 793, of Effie blood. At 29, she was in a hospital for the insane for 2 months, "suicidal and homicidal" with melancholia, after uterine trouble following non-attendance at the birth of her children. She has always been very poor. Her husband was a laborer who tried his hand at many things and succeeded in none. He was ignorant and mentally slow. At 36 he was sent to the penitentiary for 3 months for stealing farm produce. He was accidentally killed during the past year in a mine disaster. They had six children.

The oldest, VII 179, when a young child, would fall downstairs, become black in the face, and froth at the mouth, but she seems to have outgrown these attacks. At one time she was on the stage. She has a rather attractive appearance. She was a harlot before her marriage, which occurred a short time ago. She never paid her bills in any of the places where she has lived.

The second child, VII 180, has had some schooling and is a semi-skilled laborer who is trying hard to get along. He is married to an orderly, inclustrious, somewhat shrewish woman and has one child, now 5 , who is active and playful.

The third child, VII 182, now 24, has always been reputed chaste. She is of "fair mentality" and worked regularly in a cigar factory until her marriage recently.

The fourth child, VII 184, has attended school, is careful and industrious, and has ahways been considered moral.
She married a steady, industrious fellow and has three small children.

The fifth child of VI 157 is a girl, who, at the age of 11 , is in grade 3 in school and unable to carry on her work. She is inattentive, careless, sly, and very slovenly in her personal appearance.

The last child in this family, VII 187, is very slow in school, being only in grade 1 at the age of 9 .

Athena's second child, VI 158, was a harlot before marriage. She is shiftless, not industrious, and manages her household very poorly. She married a man 16 years older than herself, who is an industrious and steady-going man, but has one brother noted for his licentiousness. They have five children, all of whom are retarded in school, and slow and easy-going in disposition.

The third child of Athena, VI 160, attended school and was always reputed chaste. Now she is untidy and shiftless. She married a man much superior to her in mentality and breeding, who is steady and industrious, and has been "pulled down" by his wife. 'They have four children. The oldest, VII 193, is slightly below the average in school work, but is trying hard to get along. He is a mouthbreather, but the school physician says that there are no adenoids present. The second, VII 194, is in grade 4 at the age of 10 and is doing fair work, except that in spelling and reading he always leaves out certain letters and combinations of letters. The other two children in this family are still young. The children of VI 158 and VI 160 were born and are being reared in a community many miles away from the Juke region.

Athena's fourth child, VI 163, has attended school, and is an industrious, steady fellow who has been married twice but has no children.

The fifth, VI 164, was ignorant and a laborer who worked at anything he could find to do. He married and had one child, VII 197, a neat quiet-appearing girl, slightly below the average in school work and mentality.

The last child of Athena, VI 167, was a wild, irresponsible boy. He grew up to be a semi-industrious, inefficient man, who has cohabited with two different women and had two children.

The sixth child of Albert and Ruth was Arthur, V 53, who was a quarryman; at the age of 33 could neither read nor write, went to war, was shightly intemperate, semiindustrious, and had no property. He married an industrious, temperate, reputable, but ignorant woman. Of the 15 children born to this pair, 6 died in infancy and 2 of tubereulosis at adolescence. The oldest surviving child, a daughter, VI 174, attended school for 2 year's and can read and write. She is not very industrious, is rather easy-going, and quite hypochondriacal. She married a feeble-minded, inefficient man and has one boy, aged 20 , who is mentally slow, lazy, and conceited. She has committed incest with her father and now, although living with her husband, conducts herself immorally with others.

Her four brothers, VI 180, 181, 182, and 184, all of whom are grown, are typical Jukes - rather good-looking, semiindustrious, fond of hunting and fishing, intemperate, and licentious.

A younger sister, VI 178, was considered an average child in school. She committed incest with her father after the death of her mother. She married an industrious but intemperate and unprincipled inan, VI 179. They 
have five young children, the oldest of whom is doing average work in the third grade in school.

The last adult of this group, VI 185, was born in 1890 . She attended school 3 years, but was stubborn, wilful and mentally incapable of learning. At 15 she was sent to the House of Mercy for petit larceny and at 20 to a Reformatory for Wayward Girls. Her record shows that she had there a premature birth, was later paroled, and finally discharged.

In marked contrast to the two stories of crime and inefficiency in the family groups of Adlam and Arthur is that of their younger sister, Althea, V 56. Born in 1846, she was arrested at the age of $\mathbf{1 5}$ for prostitution and confined in the county jail for 2 days. This seems to have been her first and last lapse from virtue, as soon after that she married an immigrant and has conducted herself reputably since then. Her husband was a hard-working man, of good intent but intemperate, and considered "smart enough." He was accidentally killed by a railroad train while intoxicated (1888). Soon after her husband died Althea became very intemperate for 2 years. In 1890 she married a man 24 years younger than herself, but soon left him and is now living with her oldest daughter. Ignorant, untrained, and with a consequent narrow outlook on life, she is classed as one of the better ones of the old-time Jukes. Althea had six children.

The first, VI 188 , born in 1862 , was reputable, industrious, and fairly neat, but at present does not manage her household well. She has had some schooling, and married well. Her husband was an Englishman from a family of good reputation, and a steady worker. This pair had eight children.

The first is VII 207, a good student, who now holds a responsible stenographic position as a private secretary and is married. His brother, VII 208, who was also a good student in school, holds a responsible bookkeeping position. He has a high moral standard and lives up to it. He is unmarried. The third, VII 209, was not as quick in school as his two older brothers, but yet did his work easily. He married young, was a steady worker, but somewhat intemperate, and died under mysterious circumstances while under the influence of liquor. The fourth, VII 211, now 23, was a good student, ambitious, and well-behaved. He married VII 212, in order to legitimize their bastard child. VII 213 , born 1893 , was a good student, is ambitious, and now working hard. He married at the age of 19 . The next child, VII 214, did average work in school, was always chaste, and married young. The two youngest children, VII 216 and VII 217, aged 17 and 14, are mentally very slow and are not quick to grasp school work. They are both hypererotic.

Before leaving this immediate branch it is interesting to note the early marriage of 4 of these boys and 1 girl and the sexual precocity of the two young girls. Is this a remnant of the liypereroticism which produced a short lapse of virtue in the grandmother and the prostitution for which the other Jukes are noted?

To return to our story. The second child of Althea died in infancy. 'The third, VI 191, was born in 1871. She was a bookkeeper, was chaste, and finally married. The marriage was not happy and she left her liusband for another man. She died from the effects of an abortion.
VI 193, the next in this family, was indolent and seemed to be continually in trouble. He left the Juke region and went to Minnesota, where he is reported to have been arrested, but no State prison record of him could be found. There is no further information in regard to him. The next, VI 195, born 1876, was always reputable, makes a good appearance, but, I am told, "has been silly with the boys when younger." She married well, and has one boy, who is in the seventh grade at the age of 13 and doing well. The youngest member of this family, VI 197, is a neat, refined woman with a quiet disposition, who has recently married. Although slow in school, she has become a good inember of society.

As one studies the Jukes and finds here and there a family such as the one described above, one sees a solution to the problem of the mental defective by out-marriage into stocks entirely different from that of the deficient strain. Here an industrious foreigner was mated to an "old-time" Juke and produced a progeny of whom the greater part has been distinctly social.

The next two children of Albert died in infancy. The next, Kitty, V 60, lied a young girl. The last in this family was Andrew, V 61, who is still living. He was born in 1854 and is described by Dugdale as "a handsome boy; a loafer who cares only for shooting and fishing, and lives with parents on the town." As he grew older he became more industrious and worked luring the season in the cement mines. He has been in two serious mine accidents. In one he was given up as dead, as pieces of the cement rock had been embedded deeply in the flesh in various parts of the body. He recovered and to-dlay shows with a great deal of pricle large pieces of rock, some as large as a hen's egg, which can be felt under the skin. He still hunts and fishes. He married Sylvia, V 62, an energetic, orderly woman who has saved money, so that now the family is comfortable. They have three children.

The first, VI 200 , is a hunter and fisher, mentally slow, having reached only the fourth grade during his eight years of school life. He is one of the "old-type Jukes" and lives in a shack near his father in the old Juke country. He married a reputable but ignorant woman, VI 199, who comes from a mentally defective family. They have three young children.

The second child of Andrew is an industrious but intemperate fellow, who is married but has no children.

The last, VI 203, was spoken of as "a bright girl in school," and was always of good repute. She married some years ago, but had no children.

The fourth child of the cousin-mating of Alexander and Beatrice was Amanda, IV 9, a harlot, a recipient of poor relief and, as an old woman, nearly blind. She cohabited for many years with Lucien, IV 10. This Inan was described by Dugdale as follows: "Mason; excellent workman; idle; in middle life an habitual drunkard; deserted wife and children, and took up with Amanda; thief, though never caught; trained his children to crime; [his] father [of] good family and well off; his brother swindled him out of his property; 1850 , outdoor relief, 2 years; 1852 , died; town burial." He was reported to me as being a "thief, liar, and a inan of no principles." This 
pair had four children: Anthony, Antonio, Abigail, and Alpha.

Anthony, V 64, born 1828, was arrested at the age of 10 for stealing wood. At 26 he was arrested for burglary, but acquitted. At 42 , although he had committed a murder, he was acquitted by the court. At 44 he was in the county jail for a short period. He has received pauper relief. He cohabited with a harlot, Vida, V 63, and had a bastard child. About 40 years ago, while under suspicion for a crime, he and his family left the State and have never becn heard of since. No doubt the criminal career of this man continued. He probably changed his name upon leaving the Juke region. Although search was made for him by me in different parts of the country, no trace could be found.

Antonio, V 66, brother of Anthony, who has previously been described, was a criminal of the worst type. He was born in 1830 and has the following story in the Juke book: "Laborer; at 30, burglary, third degree, Sing Sing, 3 years; 33 , soldier; 40, outdoor relief, 1 year; 41 , attempt at rape, Albany penitentiary, 1 year; 42, outdoor relief, 1 year; attempt at rape, Albany penitentiary, 1 year; 43, outdoor relief, 2 years; 44, burglary in the first degree, Sing Sing, 20 years; syphilis." By his "wife," Ivilla, V 65, who was ignorant, inefficient, and a harlot, he had four illegitimate children.

The oldest, VI 207, was born in 1863. At the age of 11 she was raped by the man with whom her mother was living while her own father was in prison; she was sent to the House of Refuge for vagrancy. At that time she could neither read nor write. After leaving the House of Refuge, she became a harlot and was an inmate of houses of prostitution. She was arrested and sent to the penitentiary several times for disorderly conduct. She was neat in appearance, well-groomed, and of good physique and bearing. She died of gastric ulcer, inanition, and syphilis, in a road-house, at the age of 43 . Her one child, VII 222 , was also a prostitute, and died at the age of 25 .

Antonio's second child, VI 209, born 1864, was sent to the House of Refuge soon after his sister. At 16 he was still uncontrollable and did not get along well with any of the many people with whom he had been placed by the House of Refuge. In recent years he has saved a little money, but is spoken of as "below average mentally." He has a sullen, suspicious, and retiring nature, is married, and has one child.

Antonio's third child, VI 210, was born in 1866. At 8 she was sent to the House of Refuge as a disorderly child. Here she remained one year. At 11 she was returned to the House of Refuge for disorderly conduct. She was in and out of the House of Refuge until she reached the age of 18 , when she was finally discharged. She showed immoral tendencies during the whole of this period. At 18 she was sent to the penitentiary for disorderly conduct, and again in the next year was sent to the penitentiary for the same cause. She was always a harlot and died at the age of 29 .

The last child of Antonio and Ivilla, VI 211, born in 1871, was sent to the House of Rcfuge at the age of 11 for disorderly conduct and petit larceny. Here he was "poor in school work, ungovernable, and retained evil ideas." At the age of 16 he left the House of Refuge. At 22 he was sent to State prison for 1 year for burglary.
In 1894 , at the age of 23 , he was sent to the penitentiary for 6 months for obstructing an officer. He later became "half-way respectable," and married a harlot who had harl a bastard child before marriage. He disappeared some years ago and has not been heard of since.

The third child of Amanda and Lucien was Abigail, V 67. She was "a harlot; recipient of outdoor relief; keeper of a brothel, and contriver of crime." She was spoken of as "average mentally but very weak morally;" trained her children to crime and harlotry. She was also very intemperate. She married her third cousin, Benjamin, IV 63, a grandson of Bell Juke. He received a soldier's pension and also received outdoor relief. He could neither read nor write, was "rather honest," and "better morally than mentally." He spent the last three years of his life in the poorhouse, where he died in 1890 . This mating of the "average mentally but very weak morally" woman and the "better morally than mentally" man produced a progeny weak both mentally and morally.

The oldest child, VI 215, was a harlot at the age of 28 and kept a brothel. She had four illegitimate children, only one of whom, a female, VII 227 , grew up. This woman had one illegitimate chikl, now grown up, who, like her mother, is a prostitute. VI 215 then marrick an industrious though unskilled and ignorant man, VI 216. At this time the pair went away from the Juke region to a manufacturing city in Connecticut, where they raised three of the ten children born to thein. They have always been poor. The husband is now dead, and the wife, at the age of 70 , supports herself by washings. She is a great talker, is ignorant, has no breadth of ideas, and is of a defective make-up.

The first of these three children, VII 231, did "average work in school," became a harlot, married a good, industrious man, VII 230, "settled down," and had three children, all of whom did well in school and bid fair to be good citizens. The next younger is VII 232 , who was in grade 5 at 12 and, while she did good work in reading and spelling, was very poor in arithmetic and geography. She was a harlot before and after marriage. The youngest of the three who lived, VII 234, was born in 1880. An "average child in school," he showed a great deal of artistic ability and is now a skilled workman in silver. He is not inclined to work steadily, but when he does he earns good wages. He is very intemperate. He married an industrious though ignorant woman, VII 235, and had one child, VIII 88. This boy tries to do well in school, but is slow in grasping an idea and is not clever with his hands. He is a wellbehaved boy.

The second child of Abrgail and Benjamin is VI 217. Born in 1857, she was in the poorhouse at 7 ; at 13, a harlot; at 15 , forced to thieve by mother; at 17 , county jail, witness, 90 days; and also at 17, sent to the House of Refuge for disorderly conduct and prostitution. Here she was "profane and incorrigible." At 25, she was finally discharged from the House of Refuge after several futile attempts to place her' satisfactorily in private homes. She then returned to the man, VI 218 , with whom she had been living before being sent to the House of Refuge. She is remeinbered now by her neighbors as "mentally of low grade and with no sex or other control." She was inefficient, ignorant, and died childless in 1910 of paralysis. 
The next sib, VI 220, was born in 1859. At the age of 15, a truant from school and a wanderer in the streets, he was sent to the House of Refuge for vagrancy, where he remained 2 years. At 19 he was arrested for disorderly conduct and sent to jail for 30 days. Later in the same year he was sent to the penitentiary for a term of 3 months for assault and battery. At 19 he was arrested for stealing a gun and sentenced to 30 days in jail. Besides these the following records of conviction are found: at 19, stcaling chickens, county jail; at 20, assault and battery, penitentialy, 6 months; at 36, assault, county jail, 7 days; at 37 , assault and battery, guilty but discharged. He is a laborer and works rather steadily; most of his carnings, however, go into drink and most of his climes have becn committed while in an intoxicated condition. His first wife was confined in the poorhouse and then all trace of her is lost.

VI 220 later married, consanguineously, VI 567, a mentally dull, ignorant, and inefficient woman. She bore nine children to him, only five of whom are living. The home of this family knows no comforts, the floors are bare, the many broken panes of the windows are stuffed with old rags, the few chairs are rickety and unsafe, and the food is both poorly cooked and lacking in nourishment. Their oldest girl, VII 242, did fair work in school for several years. She married at 16 and has one child. At 18 her husband left her for a short while and she attempted to commit suicide by taking poison. She still lives with her parents and is an unambitious, listless-appearing girl. Her younger brother, VII 244, now 16, a cross-eyed boy, was very dull in school and incapable of learning. At 14 he was in the third grade in school and was, at that time, anemic and underfed. He was twice arrested during his fourteenth year for grand larceny in the second degree, but the cases against him were not pressed. The next child in this group, VII 245 , aged 14 , is much more active mentally and physically, and is doing average work in school. He is mischievous, though not vicious. The two remaining children are still young and are in a frightfully neglected condition.

VI 222, the next child of Abigail, born 1861, was in the poorhouse at 2 , and at 13 was sent to the House of Refuge for disorderly conduct. At 20 he was arrested for petit larceny and sent to the penitentiary for 2 months. At 21 he was arrested for threatening bodily harm to a person. At 27 he was in the poorhouse for 1 year. Subsequently he was arrested several times and scntenced three times for intoxication and disorderly conduct. He is now intentperate, semi-industrious, inefficient, and ignorant. He has cohabited with several women, having by one a girl, VII 250, born in 1890 . At 13 she was sent to a Rescue Home for disorderly conduct. At 14 she was sent to the penitentiary for prostitution. She is now a harlot, works at times in a cigar factory, is intemperate and a wanderer. She can lead and write. She has been an inmate of houses of prostitution and has led many girls into a life of shame.

The next child of Abigail and Benjamin, VI 224, was born in 1869 . Deserted by his mother at 12 , le was sent to an Orphans' Home, where he died.

His brother, VI 226, was admitted to the Orphans' Home at the same time. He was later adopted into a good family in a small city in the Middle West. The Charity Organization Socrety recolds give good reports of him. A personal visit disclosed a man with a veneer of refinement, intermittently industrious, an unskilled laborer, and generally inefficient. Although uneducated, he seems desirous that his children should do well in school. He is temperate. Some years ago, after a liaison with a woman, he married a widow with several children. He had four children by this woman. Twin boys, now 9, are still in the first grade in school, and the teacher reports them mentally below par. A girl, aged 7 , seems to be mentally more capable than the boys. The fourth is still a youngster. Several year's ago this family received much help from the town. Their house is poorly furnished, but everything is neat and clean.

The last in this group, VI 228, was born in 1860 . Her criminal record gives a perfect picture of her history. She was arrested at 17 for intoxication and sent to the county jail for 5 days; at 34, disorderly conduct, county jail, 60 days; and also keeping disorderly house and disorderly conduct, penitentiary, 3 months; at 40, disorderly conduct, prostitution, county jail, 5 days; and at 42, disorderly, county jail, 10 days with sentence suspended. She has had seven illegitimate children, only one of whom, VII 256 , survived infancy. Most of the others died of syphilis. VII 256, feeble-minded, incapable of learning in school, a harlot and syphilitic, died of neglect and pneumonia at the age of 28. This ends the description of the descendants of Abigail and Benjamin. Truly can it be said in general that this gloup "is weak mentally and morally."

The last child of Amanda and Iucien was Alpha, V 68. At 17 he was convicted of burglary in the third degree and sent to the penitentiary for $2 \frac{1}{3}$ years. At 19 he died, unmarried, and was buried by the town.

We will next consider the descendants of the cousinmating of Alfred, IV 11, and Dinah, IV 122. This group is particularly interesting because Dugdale has discussed it in his case 3, p. 21. Alfred, industrious, occasionally intemperate and the recipient of outdoor relicf, married his second cousin, Dinah, an opium-eater, ignorant and not alcoholic. They had eight children. Their oldest, Alphonse, V 70, was industrious, acquired property worth $\$ 2,000$, married, but had no children. He is now dead.

Achsa, V 72, the second child, is now living. She never had any schooling and has not improved herself mentally. She has always been industrious, and has a good reputation. She has a little property and receives a soldier's widow's pension. She married an industrious, intemperate man, Hendrick, V 71. This man, while intoxicated, killed the woman who attended the bar where he procured his drink and was sent to State prison for 2 years for murder in the fourth degree. He had five children, only three of whom grew up. The oldest, VI 231, an industrious, reputable woman, married and had one child who is now doing good work in high school. She is hypererotic. The next child, VI 232, is a laborer and is industrious, but unskilled and rather ignorant. He works at any odd job. $\mathrm{He}$ is a shy, inoffensive creature. He married a woman somewhat of his own type and has 5 children, 4 of whom in school are mentally slow and incapable of learning, although they try their best. For the past 5 years this family has received help from the town. The next two children of Achsa died in infancy. The last child of Achsa, VI 236, entered high school but left before graduation. At 19, while intoxicated, he committed an assault and was sent to the county jail for 5 days. He is now employed in a responsible position in the fire department of $Z$ 
and bears a good name in the community. He is nuarried to a neat-appearing, inclustrious woman, and has two small children.

Addie, V 74, sister of Achsa, was a hard-working woman. Nothing is known of her first husband. She acquired syphilis from her second husband and died of syphilitic consumption at the age of 28 . Her one son, VI 238, inefficient, intemperate, syphilitic, and tubercular, died in the poorhouse at the age of 39 .

Alta, V 76, another sister, is now living and bears a good reputation. Her husband was a soldier in the Civil War, acquired syphilis, and receives a pension. They have no children.

Holace, V 78, "idle and unmarried at nineteen," in 1874, worked steadily for many year's in a keg factory. Although mildly intemperate, he seems to liave always kept his family comfortably fed and clothed. He married a rather garrulous, though industrious, woman, who was also shrewish. This woman, Marie, V 79, is considered fairly intelligent and has had some schooling. Horace and Marie had 9 children, all of whom are steady, hardworking boys and girls. They tried hald to get along at school, but were unable to advance beyond the fifth grade. At the age of 14 we find them leaving school to go to work. All of them are of good repute and have married young. Horace died recently of paralysis.

With the exception, then, of one boy, VI 238, this consanguineous mating of Alfred and Dinah has produced an offspring characterized by the trait of industry. With a few exceptions it has also produced a low mental ability indicated by school retardations, which has hindered the individual in the full development of the industrious trait.

This ends the description of the descendants of the illegitimate child of Ada Juke.

\section{DESCENDANTS OF ADA'S LEGITIMATE CHILDREN.}

(Chart 2.)

We now turn to the study of Ada's legitimate posterity. Ada, after having had an illegitimate child, the founcler of the illegitimate branch just described, married Lem, II 2, a man who is commonly reputed to be a lineal, although illegitimate, descendant of a Colonial Governor of New York. Ada and Lem had 4 children: Abe, Aaron, Aurora, and Aleene. The first, Abe, III 2, indolent, licentious, syphilitic, and a pauper, married his cousin, Cora, III 29, a daughter of Clara Juke, and a woman of good repute. All their children had constitutional syphilis acquired from the father.

The first child, Amy, IV 14, was a harlot, was intemperate, lazy, weak-minded, and kept a brothel. She was also blind. She married a man similar to herself and they had eight children, six of whom died in infancy. The other two children, both girls, were harlots and unable to read and write. One was Hannah, V 83, in the county jail for disorderly conduct and also, with her child, in the poorhouse. Her sister, Jennie, V 84, has also been in the poorhouse. These two are now dead and have left no known descendants.

Ann, IV 15, a woman of good repute, the second daughter of Abe and Cola, married in turn a cousin, Ben, IV 74, a descendant of Bell and Clara Juke. Ben was a laborer, somewhat industrious in spite of being nearly blind. He had a quiet disposition, was ignolant, and considered by the populace as inentally deficient. The result on the offspring of two consecutive consanguineous matings is interesting. This group is of note also since Dugdale discussed thein in his case 1 .

The oldest child of Ben and Ann is Lloyd, V 88, spoken of in Dugdale's time as "a laborel, industrious and temperate." He was a soldier during the Civil War and now receives a pension. He is a local constable. He has never acquired any property and is now only intermittently industrious. Beyond mere ability to read and write he has little education. He married a reputable, industrious woman, Oneida, V 87, and had foul children.

The oldest, VI 256, now 42, is a coarse and shrewish harlot. She has some schooling, is a hard worker, and now takes in washings to support herself. She married early and her first child was born in the poorhouse. After all of her children were born her husband left her, and she cohabited with other men. All of her four children were taken away soon after that and placer in the Middle West, where they are doing well-morally, mentally, and physically.

The second living child of Lloyd, VI 259, a wandering actor, is married and has four children. He is now attempting to get a divorce in order to marry an actress.

The third child, VI 261, lan away from home at 14 and joined her brother's traveling circus. She was arrested by her father and committed to the House of Refuge for disorderly conduct. At the age of 16 she was discharged and at 17 she married. She is now neat and refined in appearance, is industrious and quite orderly, but clandestinely a prostitute. Her husband is a steady-working barber. The oldest of five children born to them, a girl, VII 284, did "fail" work" in school and has a quiet, gentle disposition. Her sister, VII 285, "can learn easily but won't apply herself," jumps at conclusions, and is not acculate in her work. She has an ugly temper. The three remaining children are young.

The youngest child of Jloyd and Oneida is a semiindustrious but intemperate laborer.

After the mother of these children died, and while they were still young, Lloyd brought home a shrewish though industrious widow, Nora, V 89, to live with him and bring up his children. These two are still living together, but the example set to the children while they were being reared was not of the best.

Lloyd's sister, Mary Eliza, V 90, has always borne a good reputation, can read and write, is industrious and neat, and has tried to do well, notwithstanding her ignorant and drunken husband, Keford, V 91. He was always industrious and when a young man had a kind disposition, but as time went on he drank more and more, became sullen, morose, suspicious, and finally, at the age of 67 , tried to kill his wife. Hc was committed to a hospital for the insane, and a diagnosis of arterio-sclerotic insanity was made. Both of his parents died of arterio-sclerosis. The children of Keford and Mary Eliza follow:

The first, VI 266, is a steady, hard-working fellow with some schooling. He married and had two children. The first, VII 289, is refined and neat, but is mentally incapable of doing high-school work. The second, VII 290, is careless and deceitful and does poor work in school. She is in grade 5 at 11 years.

VI 268, sister of VI 266, a harlot before marriage, is now reputable and industrious. She is garrulous and her talk 
reveals a shallow mind incapalble of reasoning beyond the little sphere of life in which she lives. Her husband works steadily, but receives small wages. He has a shallow mentality similar to that of his wife. Their oldest child, VII 291, was a harlot before marriage, but is now reputable and has one child. VII 293, a son of VI 268, has worked himself up on the railroad until now he holds a responsible position. The two younger girls are doing average work in sehool and are neat but very shy.

The third living child of Keford, VI 270 , industrious and neat, a harlot before marriage, has a shallow mind like her sister. She has two children: one neat, chaste, mentally slow but accurate; the other neat, chaste, mentally quick, and accurate.

VI 272, the fourth living child of Mary Eliza, is spoken of as "silly." She is talkative, has a pleasant disposition, and was a harlot before marriage. She has had three ehildren, two of whom died in infancy.

The last child of Keford and Mary Eliza was VI 274, a harlot who died, soon after marriage, at the birth of her first child.

Simon, V 93, a brother of Mary Eliza, is an ignorant, feeble-minded, consequently inefficient, and also licentious man. He married once and cohabited with two different women. He has always been poor and is now both erippled by rheumatism and very deaf. By his first consort, Selma, V 92, of whom nothing is known, Simon has one child, VI 276.

VI 276 was for some years in a Children's Home. At an early age she married and has had six ehildren. Her husband, VI 277, is a hard-working man, but seems to take little interest in his surroundings. He appears not to realize how socially unfit he and his family are. The wife is apathetic, disgustingly dirty, and careless about her house, self, and children. She has been given mueh help by her neighbors, but to no avail. When new clothes are given the family the mother sews them on the children, where they remain until they are past wearing; they are then cut off and a new set sewed on. No washing ever takes place. One of the six children of this couple was "bright." He died suddenly at the age of 8 . The other children are very wild, grab their scraps of food from the table, then run. They are speeimens of terrible neglect. Those who attend school do so very irregularly and are considered poor pupils. It would be interesting to note what these children could do in school were they fed and clothed properly. The family is continually moving, sometimes to avoid paying rent.

Isabella, V 97, a sister of Simon and Mary Eliza, cohabited young and had two children. At the age of 24, deserted by her man, she went to the almshouse with them. The two children were placed in an Orphans' Home, where one died, while the other ran away and has disappeared. Isabella left the almshouse soon after the children had been disposed of. She then colabited with another man and had two illegitimate girls, who in turn have become harlots. She then married her cousin, VI 611, but had no children by him. She died poor and negleeted in 1910.

Imogen, V 98, next younger than Isabella, married her cousin, Levan, V 253, a descendant of Bell and Clara Juke. She was of good repute at that time. The family was poor, as Levan was a semi-industrious laborer and saved no money. In his later years he has committed rape on several young girls. He and his wife had three ehildren. The eldest, VI 287 , is ignorant, mentally slow, licentious, indolent, and has little ambition; she married a man of poor mentality, but who had the redeeming trait of being industrious, and they had three boys. These were ineapable of learning in school and will grow up unskilled and unlettered, and consequently unable to get along well in life.

The seeond child of Imogen, VI 288, was sent to the eounty jail for a term of 6 months for burglary in the third degree. He escaped from jail and upon being apprehended was sent to State prison for one year. He is a laborer, unlettered, with little sehooling, is married, and has two small children.

The third ehild of Imogen, VI 290, much like her older sister, is ineffieient and a prostitute. She eohabited with VI 291 and they had seven ehildren. This man is industrious, has some schooling, and, with a real helpmeet, "would be quite a man." As it is, the family lives in filth and squalor and the ehildren are underfed and halfelothed.

Pius, V 100, a brother of Imogen and Isabella, has always borne a good reputation, is a laborer, and has always worked steadily, although he never had any sehooling. He is married and has two children - a son, VI 293, industrious and "steady," and a daughter, VI 294, who seems always to have been reputable, is now married, and has three children.

Hulda Ann, V 103, sister of Pius, was born in 1860. She married Shy, V 102, when she was young, but left her husband in order to cohabit with Valentine, V 104. This man is a hack driver in a small town and his earnings are small and somewhat irregular. He is a big brute of a fellow and has quite a temper. Hulda Ann has been obliged to do plain nursing to help the family finaneially. She has fair intelligence, though little edueation. They had one illegitimate ehild, VI 296, who was quite eapable in school and during her first year in high school did average work. She soon dropped out, however, went to work in a faetory, and is now a harlot.

Augusta, IV 17, a sister of Ann and daughter of Abe and Cora, was an ignorant but hard-working woman. She married Hezekiah, IV 16 . These two were helped by the town for 3 years just previous to the time Hezekiah went to the poorhouse, where he died at the age of 40 of tubereulosis. They had four ehildren, two dying in infancy.

The oldest, a boy, Hannibal, V 106, was born in 1844 and was placed while yet young in a good family in the Juke region. He learned the blaeksmith trade, and, meeting with many people who eame to his master's shop, he soon learned to "dieker" and became quite adept at striking a bargain. He enlisted in the army at the outbreak of the Civil War and served through the whole war. He became an actor and was very suecessful; then he entered the theatrieal busmess, in which in the course of ten years he cleared $\$ 100,000$. This he invested in a stoek farm and became the owner of two famous stallions of that time. The plays he produced were mostly western dramas. The scene of one of his best-known plays was laid in the town of $Y$, in the heart of the Juke eountry. Hannibal's stage name was on the tongues' end of the whole theatergoing public of 20 and 30 years ago. He became finaneially embarassed in his later years, grew despondent over 


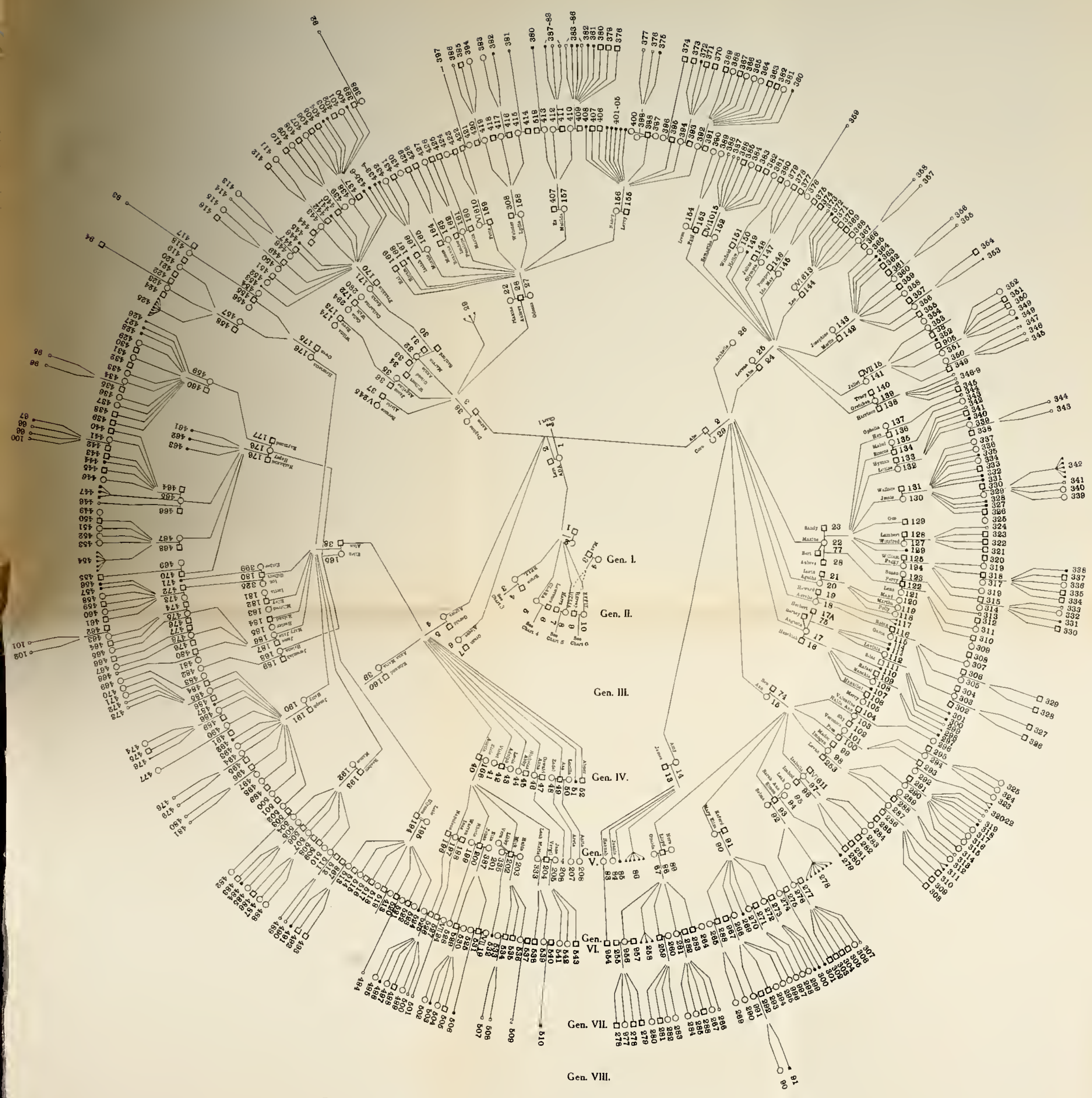

Chart 2. Genealogical Tree of the Descendants of the Legitimate Children of Ada Juke, as recorded in 1915. 


.


a broken wrist which refused to heal, and, fearing an operation which was deemed necessary, he committed suicide at the age of 64 . He was married but had no children. He had a kind, generous disposition, and disliked to see want and suffering. At one time while the play laid in the Juke region was being enacted in $Z$, he sent out 100 passes to many of his old friends of this place, mostly Jukes.

Hannibal's sister Nanchia, V 108, was a waitress and worked in a hotel. She was a harlot and thus aequired syphilis. She cohabited with a man and had two illegitimate children, both of whom died. Nanchia is now dead.

To return to Augusta: After Hezckiah, her husband, died, she charged bastardy on her cousin, Barney, IV 75, and he married her. He was, however, impotent. After they had lived together five years he died of eonsumption, and she lived then with Herbert, IV $17 \mathrm{a}$, who later deserted her. She had by Herbert one daughter, Lavinia, V 112, and two bastard boys who died in infancy. Dugdale's record of Lavinia follows: "At 7, misdemeanor, eounty jail; harlot before marriage; 18, poorhouse, mulatto child born; tried suicide twice; 19, married; in service; syphilis." Two of her children died of syphilis. She was inentally defective and is now dead.

Aurelia, IV 18, sister of Augusta, was a harlot before marriage and had one illegitimate son, Robin, V 116. She then married and had two ehildren who died in infancy. She was murdered some years ago, but the details of the murder could not be secured. Her son Robin aequired a little property and now owns a eanal boat.

Robin and Gama, V 115, married and had three girls: one, a prostitute, had two illegitimate children; one married well and is now dead; the third is industrious and reputable but ignorant. She has reently married.

Agatha, IV 20, a sister of Augusta, was a harlot. aequired syphilis and lived in her sister's brothels. She had three illegitimate daughters; two have disappeared, the third, Maud, V 120, who eould not be found by me, was adopted into a private family and is reported by Dugdale as doing well.

Maxine, IV 22, was another sister of Augusta and Agatha. She was a harlot and at the age of 25 had a bastard son by her eousin Aubrey, IV 28. This boy, Perey, $\mathrm{V}$ 122, had no edueation, but has grown up to be an honest man of fair intelligence. He is a laborer, works steadily, pays his debts, and has aequired a small farm on which he lives. By his first wife, Lena, V 121, a good and industrious woman, he had two children, a boy and a girl. Both were eapable in school and are quiet and industrious. After his wife died Percy seeured a widlow, Susan, V 123, as a housekeeper, and in 1912 had a bastard son by her.

Maxine, after the birth of Percy, married a cousin, Bert, IV 77, a descendant of Bell and Clara Juke. He was impotent and she procured a divorce from him. She then cohabited with Sandy, IV 23, an ignorant, semi-industrious, intemperate wanderer. After being on the eanal for some time Sandy and Maxine went to work on a farm 50 miles from the Juke region. "They "never" amounted to anything" and both are now dead. This pair had seven bastard children: Peggy, Winifrel, Gus, Jessie, Iouise, Roseoe, and Helr.

The oldest child, Peggy, V 124, is an ignorant, hardworking woman. Her mind is "shathow" and her appreciation of causation somewhat deficient. She lras now a slight memory defect. The belief lampant among the Nams that they were to inherit a large sum of money crops out here and there among the Jukes. Peggy lives on and works hard to support the family, comforting herself that some day she is to inherit a great sum of money from an ancestor. Peggy, when very young, married William, V 125 , a member of a very degenerate family in the neighborlood in which she was born. William is a hard-working though unskilled man, earning $\$ 7$ a week regularly. All his wages go, and have gone for many years, into drink, and fol the last 20 years Peggy has done washings to supply the daily bread. While under the influenee of liquor William becomes ugly and has threatened harm to his wife. He has been arrested many times for drunkenness, but never senteneed. He lives in rather poor conditions in a small city away from the Juke region. William and Peggy have four ehildien.

VI 315, a male, ignorant, ineffieient, intemperate, and poor.

VI 316, female, who died young.

VI 319, a clandestine harlot before marriage and ignorant, but a steady worker, neat and fairly eapable.

V'I 318, male, has never had any schooling, is intemperate, though not so much so as his father, works steadily at times, is eonsidered of fair mentality, but is inefficient and can not keep a position long. He has lived for 11 years with VI 317, a young married woman deserted by her husband. She is a hard-working ereature and takes in washings to help along. She has neglected the five children she has had by the last mating and also the one by her first mating. This neglect is probably due to ignorance ard general inefficieney as well as inability. She was siek with rheumatism some years ago and the whole family was helped by the town for 2 years. This couple had five children. The first, a boy, VII 334, now 11, is below average in school and had infantile paralysis at 3 . He is poorly nourished and ataxic in his movements. The second, VII 335, aged 9, is a boy who is good in school and does average work. He is underfed and anemic. The next two, a boy and a girl, VII 337 and VII 336, are still young and are in a neglected and underfed condition. The fifth, VII 338, died at the age of 3 months of cholera infantum.

$\mathrm{V}$ 126, a daughter of Maxine, died in infancy.

Winifred, $V 127$, the next child of Maxine, married young, went away and died at the age of 40 . All trace of her four sons is gone.

Gus, Y 129, was accidentally ehoked to death at the age of 7 .

Jessie, V 130, the next daughter, is much like her sister Peggy in mentality and behavior. She married Wallace, $\mathrm{V}$ 131, a member of a degenerate family and distantly related to William, the husband of Peggy. Wallace, at the age of 15 , was arrested with his father for burglary. He was not sentenced, but his fathel was sent to State prison for 15 years. He inherited an unproductive farm and buildings on the top of a mountain. Here he lives, spending his time in hunting and fishing. He is a capable blacksmith, but is poor because he is too lazy to work at his trade. He is very intemperate and when intoxieated 
he abuses his wife and children. The house he lives in is fast falling to pieces and is almost destitute of contents. Jessie brings in most of the money which keeps the family from starvation. Wallace and Jessie had eleven children, five of whom died in infancy. The six living children are next described.

The eldest, VI 326, aged 34, like his father is very intemperate. He attended school, but could not advance beyond the third grade. He is a section hand on the railroad and works steadily, but spends all his small wages in liquor. His wife is more intelligent than himself, is semiindustrious, and fairly neat in their home, but is intemperate at times. This house is on the mountain side directly across the way from that of Wallace. It is made from pieces of the sides of freight cars gathered from a train wreck. The outside and roof are covered with tarpaper. The three rooms inside are barely furnished. VI 326 has no children.

VI 329, the second living one in this group, was "stupid" in school, married young and had eight children, five of whom died in infancy. Her husband, VI 330, an inefficient laborer, is continually moving his family here and there.

The third, VI 333 , aged 22 , is mentally slow and was 11nable to grasp school work. He is unindustrious and, like his father, is intemperate.

The fourth, VI 334, aged 19, has been brought up in the mountains away from any refining influence, and has no morals. She had no taste for books at school and left as soon as she reached the age of 14 . She is intemperate and cluring her visits to a nearby city she associates with low, vicious characters.

The two youngest children, VI 336 and VI 337, are feeble-minded. They are in school, but are unable to progress in their studies.

Next in generation V is Louise, V 132, a sister of Jessie and Peggy, a woman who is ignorant and untrained, but persistently industrious. Her husband, Hyman, V 133, is a farmer. He has tried many things in order to earn a living, but has succeeded in nothing. He is temperate but ignorant and "lacks judgment." The oldest child of Louise and Hyman, VI 339, is mentally deficient and shy and has a shifty demeanor. She is married to a cousin in the out blood and has two small children. Louise's two other children are still young.

Roscoe, V 134, a brother of Louise, had a "fair amount of brains," but was untrained and very intemperate. He cohabited for some years with a woman by whom he had one child. Later this woman deserted him, took the child, and has left no trace. Roscoe was accidentally killed some years ago while working as a laborer.

Hen, V 136, brother of Roscoe, has had little schooling, but is considered "of fair mentality." He is intemperate, but is industrious and has a steady position on the railroad. He is now cohabiting with a married woman who has left her husband.

The next child of Abe and Cora was Aba, IV 24, and the last was Arabella, IV 26, an idiot with constitutional syphilis, who was in the poorhouse at 16 and probably soon died, as the records of her disappear at this point. Aba inherited constitutional syphilis from his father. At 12 he was in the poorhouse for 3 years. He became a laborer and, although temperate when young, was alcoholic in later years. He married Lorena, IV 25, of a degen- erate family, ignorant but semi-industrious. At 34 Aba broke his leg and during this time he and his family received outdoor relief for 1 year. Aba was always poor and at the age of 40 went to the poorhouse, where he remained 24 years until he died. They had ten children, one of whom died in infancy. Those who grew up were: Gretchen, Juliet, Merlin, Len, Ida May, Olympia, Hattie, Samantha, and Paul.

Gretchen, V 139, was mentally deficient, had no schooling, and was a harlot. She married and had four children, who were placed in a Children's Home; all trace of them has been lost. Gretchen left her husband, cohabited with others, and finally died of consumption at the age of 42 .

Juliet, V 141, who never had any schooling, was considered much more intelligent than Gretchen. At the age of 16 she married VII 15 (see chart 1 ) of $X$ blood, an indolent, inefficient, licentious man who inherited land from his father. This pair had four children.

The first, VI 349 , was unlettered, inefficient, indolent, and left his wife and four young children to cohabit with a cousin, VI 910 (see Effie).

The second, VI 351, was mentally deficient and unable to read or write. She married consanguineously and tried to do well by her intemperate, inefficient husband, VI 905 (see Effie), and four anemic, poorly fed, and mentally deficient children. She died of syphilitic consumption and neglect at the age of 37 .

The third child of Juliet, VI 352, died at the age of 4 .

The fourth, VI 353 , aged 23 , is unable to read and write and is not active mentally. Although very young at the time of her mother's death, she soon left home and went into service. At 14 she married VI 38, a cousin (see Ada, page 7), and has several small children. VI 38 is only semi-industrious and the family is in poor shape.

Merlin, V 142, the next child of Aba and Lorena, could neither read nor write, was only semi-industrious, and, on the whole, inefficient. He was always a laborer, was very intemperate, was convicted twice for public intoxication and served ten days in jail. He was "not considered smart" and was always poor. He died of an overdose of liquor or poison in a disorderly saloon. His wife Josephine, V 143, a member of another mentally deficient and degenerate family, also of the Juke region, was mentally slow, ignorant, and only semi-industrious. After Merlin's death she cohabited with other men. Merlin and Josephine had nine children, of whom two died in infancy.

VI 355, male, ignorant, semi-industrious, licentious, is now dead as a result of a drunken brawl.

VI 356, female, mentally slow and incapable in school, semi-efficient, married a man who has another wife and a child living.

VI 358, a feeble-minded prostitute, has been in the reformatory for disordery conduct.

Two boys, VI 359 and VI 362, are of low mental grade and inefficient.

VI 360 , female, mentally inactive but fairly industrious, married and has two small children.

VI 365 , female, now 12, does fair work in school.

Len, V 144, a brother of Merlin, has never attended school and can neither read nor write. He married at 19 , but 6 months later left his wife. He then lived with a cousin, VI 613, a descendant of Bell, Clara, and Delia Juke, thus producing an offspring having A, B, C, and $D$ blood. She is ignorant, causationless, untrained, inefficient, and dirty, but industrious. 
V 144 and VI 613 had: VI 367, a girl, mentally slow in school, a harlot, and now married; VI 368, a boy, 19, good in arithmetic, but very poor in other subjects in school, and now working as a laborer; VI 369 , a boy of 13 , doing the same work as his brother in school, but anemic, underfed, and neglected; VI 370, a boy slow in school and very neglected; two children still young and neglected; and one child dead, who completes the family. Len is now a farm-hand and works steadily, but makes only a dollar a day and is slightly intemperate. Thus the family lives in want and in filth.

Ida May, V 145, now 44, was incapable of learning at school and was a harlot before marriage. When young she went into service and it is reported she had a bastard child, of whom there is no trace. She married a temperate, industrious, but tuberculous farm-hand, Pompey, V 146, and has two sons. Of these, one, VI 374 , is an average child in school; the other, VI 375, is retarded, lazy, and inattentive. Since marriage, Ida May has done housework by the day to help support the family. They live in poor conditions in a tenant house in the country.

Olympia, V 147, very slow and unable to learn in school, married when young an intemperate, shiftless, semiindustrious laborer named Julius, V 148, who, when intoxicated (which is often) is abusive to his wife and sometimes cruel. She has left him at intervals, but each time has returned upon his promises to do better. Some time ago Julius was arrested for stealing chickens and sent to jail. Olympia has always worked hard and earned much money by taking in washings. Besides taking care of the family she has saved enough so that she has purchased a house and lot worth $\$ 2,500$. A religious and very philanthropic lady of $Z$, the same who was interested in VI 459, has spent a great deal of time and effort upon this woman and has succeeded to a great extent in inducing her to attend church and to lead a social life.

Olympia and Julius had three children: a son, VI 377 , a laborer by occupation, slow in school, lazy, vicious, and always in trouble, now married and with one small child; a son, VI 378, like his brother, except that he is a telegraph operator and unmarried; a daughter, VI 379, a plodder, who made good use of her time in school, and is now a stenographer and reputable.

V 149, brother of Olympia, died young.

Hattie, V 150 , now 40 , was very slow in school. She went to work young and has always borne herself well. She married an industrious, steady man and they have one boy, who at 13 is doing average work in school, and has good social traits.

Samantha, V 152, sister of Hattie, was born in 1878. She is remembered by her teachers as being very slow and incapable in school. She married, when young, a cousin, VI 1015, a descendant of Effie, ignorant and intemperate at times, who, although a steady worker, is able to earn but small wages. Samantha takes in 10 to 12 washings a week. The two older children also work. In spite of all these sources of revenue the family is almost destitute, because the parents are unable to spend intelligently and with foresight.

Samantha had eight legitimate children: VI 381, now 18 , as a girl mentally slow and unable to retain facts, a harlot, now employed in a cigar factory; VI 382, a boy, "cranky," indolent, with some mental ability but with little desire to use it, and now working as an errand boy in a store; VI 383, a boy, cross-eyed, trying hard to do fair work in school; a girl, VI 384, now 11, who is a good worker in school, being in grarle 4, and who has a quiet disposition; VI 385, a boy, now 10, a thin, pale-faced, anemic child who can not learn to rearl or to retain well, although lie does number work fairly accurately; VI 386 , a boy, now 7 , doing well in grade 2 in school; and two children under 5, both neglecterl.

Paul, V 153, the last child of Aba and Lorena, is intemperate, but a steady worker as a farm-hand. He married Irene, V 154, and had two children, but has left his family and does not support them.

Abe's brother Aaron, III 3, a son of Ada, also married a cousin, Daphne, III 38, a descendant of Delia. Aaron, according to Dugdale, was a "farm laborer; at 26 , soldier, 1812; somewhat industrious; acquired 14 acres of land; willed it to his children; temperate; father of a bastard before marriage; received a U.S. pension; 1874, outdoor relief, 1 year," Daphne was healthy, industrious, of good repute, and died of old age in the year 1867. They had seven children: Aubrey, Annie, Angeline, Alaric, and three still-born children.

Aubrey, IV 28, the first, was a laborer and industrious. At 26 he was the father of a bastard boy by his cousin Maxine, IV 22, already described on page 19 . He then married Odessa, IV 27, a woman of good reputation, but shrewish and a poor housekeeper. They had ten children: Nancy, Matilda, Lydia, Fritz, Penelope, Roxanna, Minnie, Hiram, Hal, and one who died in infancy.

Nancy, V 156, born in 1855, has never attended school, and can neither read nor' write." At 13 she had "brain fever resulting in St. Vitus dance," but she outgrew this. At 15 she married Leroy, V 155, a cousin in the out blood. Nancy has always worked hard and is neat and clean in her housekeeping. She has fair intelligence and has always borne a good reputation. She is very patient with and devoted to her ill-tempered, drunken husband. Leroy can neither read nor write. He was a soldier in the Civil War, lost one arm during it, and is now receiving a pension of $\$ 40$ a month. He owns a small farm, but it is unproductive and he has always been too lazy to attempt to make use of it. He is deceitful, very intemperate, and now bed-ridden. When excited he stutters. Nancy had twelve children, six of whom died in infancy.

VI 392, the oldest child of Nancy and Leroy, is a hard worker, keen in business affairs, and good at driving a bargain. In summer she hawks vegetables raised on her' husband's farm. Her temper is seldom disturbed, but when aroused it is ungovernable. This temper appears to a greater or less degree in all of her children. When quite young she married VI 391, who worked hard, acquired a farm, and is now putting money into the bank. Their oldest child died in infancy. The next, VII 361, works hard at home and is self-denying. She is somewhat shy and her voice is thick. The next, VII 362, did not do very well in school, but is a well-hehaved boy and now works on his father's farm. The fourth, VII 363, while not doing well in school, has a good business head and is very capable. He can not say "G" or "St" and when excited stutters very much. VII 364 , now 17 , was an average pupil in school and is well spoken of in the community. She was born and reared within a mile of the original Juke country, though not directly in the five-lake region described by Dugdale. VII 365 , now 12 , is a very nervous child. When crossed or spoken to severely she laughs hysterically. She is retarded 3 years in school and 
does poor work, except when treated with the utmost patience and kindness. 'The next youngel child, VII 366, is in grade 3 at 10 years and works well under kind treatment. Her teachers say "she takes her temper out in crying." She does not exhibit as much speech defect as her older sister, VII 365. Of the three youngest children, one has a speech defect and an ungovernable temper.

The next daughter of Nancy and Leroy, VI 394, can read but not write and has attended school but a very short period. She married very young and has lived an uneventful life, having three boys, two of average and one slightly below average mental ability.

The first son of Nancy, VI 395, stutters very badly. He is a laborer and very ignorant. He married and has one child who also has a speech defect and is left-handed; mentally he is quite acute.

The second son, VI 398, has had quite a varied career. He stuttered very much as a youth, but has outgrown it. He played "hookey" so much at school that his teachers could make nothing of him. He has a pleasant disposition and is quite talkative. His marriage relations have been many. His first wife was a divorced woman and he in turn divorced her when he discovered that she was having immoral relations with negroes. This happened when he was 23. He then enlisted in the SpanishAmerican war. At 27 he married again and this wife died of Bright's disease. Although he was forced into his third matrimonial venture by the birth of a bastard boy,this marriage proved to be a fortunate one. He and his wife, although she had two other bastards previous to this, are well mated and with care and economy are providing a good home on his $\$ 10$ a week.

The last two sons of Nancy, VI 406 and VI 407, are now in their twenties and are both stutterers. They work when they feel so inclined, which is seldom. Although both have attended school, little progress was made by either. This lack of progress was due to a low state of mental development.

Matilda, V 157, the second child of Aubrey and Odessa, was a harlot before her marriage to her cousin $\mathrm{Ez}, \mathrm{V} 407$, a descendant of Effie. She is unable to read and write and is now mentally inactive. Her disposition is shrewish and she is a continual faultfinder. She is filthy in appearance and her house is no cleaner than herself. This woman has many of the traits of the older Jukes. Her husband, Ez, apparently at one time was quite industrious, for he acquired a house and 1-acre lot. Now he says, "I suffer from heart trouble and am unable to work." $\mathrm{He}$ takes life as it comes and receives help from the town with apparent reluctance. Their three children are all girls.

The first, VI 410, was born in 1875 . She was mentally inactive, causationless, and a slattern. Before her marriage she was very immoral and married VI 409, a degenerate of the lowest type, who was a son of Lisle, V 195, by another mating. Their five children, all mental defectives, were brought up in squalor, ignorance, and depravity. She has alway's been intemperate and at the age of 37 died suddenly while in a drunken stupor.

In contrast to this one is her sister, VI 412, who has always borne a good reputation and though very poor has tried to do her best by her family. She is of a much higher order of intelligence than her sister, is married, and has two small children.

Her youngest sister, VI 413, was capable of doing average school work, but was too lazy to apply herself. She cares little about her personal appearance and has been a harlot, both before and after marriage. She married a cousin, VI 519, a descendant of Effie, by whom she had one child who died young. She is now easy-going, lives from hand to mouth, and cares little what the future may bring her:

Iydia, V 158, Matilda's sister, was rather active physically and mentally compared with Matilda. She had a sharp tongue, was suspicious and keen in her daily dealings. A harlot before marriage, she married a distant cousin, Webster, Y 308, of Delia blood, who afterward became blind. Webster and Lydia kept a small grocery store for many years in $Z$. Lydia could read and write, but was otherwise ignorant and her power of reasoning was below the average. At the age of 53 she shot herself and died instantly. Her death was followed in a short time by that of Webster, and VI 417, their daughter, is now running the store.

The oldest child of Lydia, VI 415, died soon after marriage, following an operation on her throat.

The second child, VI 417, was considered an average child in school; she married, but her husband soon died. Her second husband is a lazy ne'er-do-well. By her first marriage she had two children, one of whom died. Since her second marriage she has worked in a factory and is now running the store to support the family.

The youngest child of Lydia, VI 419, was, as the teacher expressed it, "average but slow" in school. She then went to work in a cigar factory, where she earned $\$ 5$ a week. She married at 21 and has three children.

Fritz, V 159, a brother of Lydia and Matilda, born 1862 , never had any schooling, but by working hard and saving has acquired a little property and a savings-bank account. Fritz married, consanguineously, VI 610, a descendant of Bell, Clara, and Delia Juke, and a woman of good reputation but not as intelligent as he. They had two sons, both of whom have become telegraph operators and have done well in their business. One of the boys, VI 422, is the father of an illegitimate child and left town to avoid trouble.

Penelope, V 161, sister of Fritz, had a bastard child which was accidentally drowned at the same time as Aubrey, Odessa, Hiram, Hal (the latter being the two brothers of Penelope), and a neighbor's child. Penelope then married an inefficient alcoholic and had two children, a boy and a girl, both slightly below the average mentally, but both industrious. Penelope and her husband are now both dead.

Roxanna, V 163, sister of Penelope, is another one or the Jukes who was pointed out to the witer as one of the "old-time Jukes." She lives in Z, a small eity. This woman, who was a harlot before marriage, has a generally pleasant disposition, but occasionally is very irascible. She married an intemperate laborer who was industrious at times, Moses, V 164, who came from a higher family mentally than herself. She has had him arrested several times for non-support, but many think these arrests were part of her irascible nature and that there was little if any ground for them. For many years she has lun a small grocery and candy store in the basement of her home, while the upper part of the house has been used for purposes of prostitution. They have been arrested for the latter business, but were never sentenced. While Moses was, supposedly, under the influence of liquor he was killed ly a fast train several years ago. Roxanna had two sons, 
VI 428, a boatman who has cohabited with a married woman living apart from her husband, and VI 429 . The latter's wife died at childbirth. Both of these boys are steady workers, but the moral example of their parents has done them more harm than good.

Minnie, V 165 , born 1870 , more intelligent and better educated than any of her brothers or sisters, married at the age of 17 . She has a pleasant disposition and is careful and neat about her person and house. She had four children, only one of whom is living, a sturdy but mentally dull boy. Her husband, Isaiah, V 166, a steamboat engineer, left her some years ago and she is now cohabiting with another man. Minnie had one sister, V 167, who died in infancy, and two younger brothers, Hiram and Hal, who were drowned as mentioned above.

Returning again to our main line, let us consider Angeline (b. 1833), sister of Aubrey, IV 28, son of Aaron. She is described by Dugdale as follows: "Insane tendency; husband beat her; assault and battery, county jail, 90 days; first husband killed morning after marriage; at 36 , melancholic; at 41 , suicide." She married an habitual drunkard who was also a pauper. They had one son, of whom nothing is known.

Alaric, IV 37, born 1835, brother of Angeline, was a "laborer; lazy; 1857, outdoor relief, 1 year; 1864, outdoor relief, 2 years." He enlisted in the Civil War and now receives a pension of a dollar a day. He owns a small place in $Z$, is cross and cranky, but takes good care of his wife Bernice, V 245, who has been blind for 40 years. Bernice is a descendant of Bell, Clara, and Delia Juke, and is a typical person of that blood, both in appearance and behavior. She is ignorant and superstitious and has no children.

Annie, IV 32, sister of Angeline, was born in 1829. She had one illegitimate child by Sanford, IV 30. She then married, but her husband was killed while committing a bank robbery. She cohabited with Gilead, IV 33, who had been sent to State prison for 3 years for burglary in the third degree. She had one child by Gilead, Walt, V 172, who is semi-industrious but intemperate. He married consanguineously, Catherine, V 290, who died leaving no children. He then married her sister Celia, V 294, but is not living with her at the present time. After Gilead's death Annie went to live with another man.

Sarah, V 171, Annie's daughter, was born in 1843 . She had never any schooling or desire to broaden herself by study, has a defective make-up, is a "typical Juke." At times she is intemperate. She works only when disposed to and as a result does not accomplish much. Her house is kept in a neat condition, but her personal appearance is far from being so. Her husband, Franklin, V 170, has always been a steady worker, but he puts the money he earns into wild-cat schemes and therefore is very poor. Several years ago he built a small house which still remains unpainted. He is temperate and bears a fair reputation in the community. Soon after marriage Franklin and Sarah moved from the Juke region to a small manufacturing city in a neighboring State, where they still live. The children of this couple who grew up are now described.

The first, VI 438 , now 45 , did average work as a pupil in school, but soon after leaving became a clandestine prostitute. This career was closed with her marriage at
17 to VI 437, a man of energy and push. She is fat, liumorous, and jovial, is capable and makes a good wife. Three of the eight children born to her and her husband died in infancy, two are well married, two boys are in school and, though mentally slow, are doing fatir work, and one chilk is still young.

VI 440, the second living child of sarah, atthough a steady worker, is contimually inoving here and there and so has never accumulated anything. He is now rather poor, is married and has three children: a boy, VII 408, mentally deficient, and a typical "street tough"; a girl, VII 409, rather refined, quiet, and honest; a boy, VII 410, half way between the two in character.

The third living child of Sarah, VI 443, was capable in school but a harlot before marriage. She is now a hard worker and very neat, and bears a good reputation. By her first husband she had two children who are bright, intelligent, well brought up, and of good character. She has had two other marital experiences.

VI 447, son of Saral, now 31, was an average pupil in school, went into an office, and is now a traveling salesman with a good position. He is married, and his one chitd, now 10 , is a neat, well-behaved, capable girl.

The next in this group, VI 449, is not as "smart" as the others, but is a steady-going man and tries hard to get along. He married an intelligent, tidy, capable woman and has two children: a girl, aged 7, who is ataxic and mentally confused, and a boy, aged 5 , normal physically.

The last in the family under description is VI 451, and he resembles the okl Jukes in caliber. He is intemperate, a wanderer, and only semi-industrious; is married, but has left his wife.

Here an out marriage and a new environment many miles from the old Juke country are producing a new type of people-for the most part energetic and capable, both physically and mentally. Three out of these six children of Franklin and Sarah are socially fit. Of the other three, one has two undesirable children; another has one; and the third has no descendants.

Ada's third legitimate child was Aurora, III 4. Aurora was a "harlot; not industrious; healthy; temperate; 1835 , poorhouse, 1 year; child born; dead." She married Gerakl, III 5, a "laborer; mulatto; licentious, lazy; no property; 1830 , county jail; syphilis." The mating produced nine children: Alan; Anna Maria, IV 39, whose descendants will be described under Effie Juke; Austin; Adolph, IV 42, "laborer; octoroon; 1835, poorhouse, 1 year; lazy; licentious; intemperate"; Abby, IV 44, octoroon, who married a mulat to; Anna, IV 46, "harlot; born 1822 ; at 35, widow with 4 children, outcloor relief, 2 years; lead"; Asa, IV 49, "laborer; syphilis; licentious, lazy; at 2 , poorhouse, 1 year; 7 , poorhouse, 1 year; 46 , outdoor relief, 1 year, intemperate"; married and had two girls, both of whom died in infancy; IV 51, "at 1, poorhouse, died young"; and Abner, IV 52, "1835, born in poorhouse; fate unknown."

Alan and his brother Austin married, consanguineously, two sisters, Ellen and Elsie, two descendants of Effie Juke. Alan, IV 38, was licentious. From 1840 to 1863 he received much help from the town. In 1853 he was convicted of assault and sent to the county jail. When seen by the investigator he was an old man of 95 , was short and fat, and had many bodily ailments which he commented upon. He was mentally deteriorated and, though a great 
talker, could remember but little of his recent past. He was ignorant and superstitious. Although he was somewhat deaf, his eyesight was good. He received a soldier's pension and owned a house and small farm which his son Riley worked. He died of apoplexy at the age of 95 . Although given by Dugdale as an octoroon, I could see little evidence of negro blood in him. He had rather the features of an Indian. His wife, Ellen, IV 165, was a harlot and kept a brothel. She was lazy and acquired epilepsy.

Alan and Ellen had eight legitimate, and Ellen two bastard children. The legitimate children were: Henrietta, Gilbert, Riley, Roland, Mary Jane, Hetty, Reuben, and Ulysses. The illegitimate were Hepsy and Helena.

Henrietta, V 176, is described by Dugdale as follows: "Harlot; kept brothel; at 21, disorderly house, county jail, 2 days; 29 , outdoor relief, 2 years; 33 , outdoor relief, 1 year; 1869, died." She married Owen, V175, a member of a mentally weak family. Henrietta had two children, a boy and a girl, both probably illegitimate.

VI 455, the son, married and went away from the Juke region into a large city and has disappeared.

VI 457, the girl, became a harlot and later cohabited with VI 458, an itinerant horse doctor. He was intemperate, has been in the county jail, and, at the age of 58 , was in the poorhouse afflicted with rheumatism. This couple had two girls, both prostitutes, and also seven children who died in infancy. One of these girls, VII 423, a woman of fair intelligence and quiet manner, had a child by a man with whom she lived. After he was blown to pieces in an accident, she went to live with and now has married a rather industrious, steady man.

Hepsy, V 178, the second child of Ellen, was illegitimate, and she in turn had a bastard girl, VI 459, and after this went to live with Nathaniel, V 179. Neither he nor she had ever had any schooling and were very ignorant. They tramped the roads begging and stealing what they could and were both very intemperate. It was a common sight formerly to see the couple staggering along the roads trying to sell baskets which they had made. They received much help from the town as well as from private individuals. Nathaniel was convicted of petit larceny at one time and sent to jail. The couple lived in a hovel for many years until 1903, when they went to the poorhouse for a year. They were in and out of the poorhouse during the next few years and Hepsy died there at the age of 65 , but Nathaniel did not die until 2 years later, at the home of one of his children. They had six bastard children: three died young, and two girls and one boy grew up.

VI 459, the first child of Hepsy, was born in 1858. At 16 she was sent to the House of Refuge for disorderly conduct and prostitution. She was placed with a very refined family in $Z$ after discharge. In spite of the fact that after this she had a bastard child which died, the influence of these people has been good. At 18 she married and had ten children, the first two of whom died young. From the time of her marriage until the present day she has tried to do well. She has worked hard and, in the face of misfortunes which would have discouraged many another person, has put all of her children through school, and all eight are now industrious, refined, and ambitious children. She is quiet-spoken, neat, and refined. Some years ago the house in which she lived was burned, but she immediately started out again undaunted. Her hus- band, VI 460, a newspaper reporter and collector, had forged notes and stolen money. He was very egotistical and a great takker, very erotic, and mixed up at one time with some indecent publications. He has never been able to hold any position long and has always made poor and irregular wages.

In decided contrast to VI459 is her half sister, VI 465. The latter was born and brought up in a home where harlotry and poverty were ever present. This woman never had any of the refining and uplifting influences of a good home presented to her. She can read and write a little, but otherwise is densely ignorant. When young she went to live with VI 464, later marrying him in order to receive her soldier's widow's pension after his death. This man was 62 when he first cohabited with VI 465, who was then 17, and was descended from a respectable family. He was ignorant and slightly intemperate, but always paid his bills. He had been a soldier in the Civil War and received a pension almost large enough to support him and his fanily. They had six children, four of whom matured.

VII 440, the oldest, is untrained and makes a poor living as a laborer.

The second, VII 441, now 21, married very young an inefficient, criminal man and has several small children. She is a shy, ignorant, causationless girl.

The third and fourth children died young.

The last two legitimate children, VII 445 and VII 446, are still in school and, although retarded several years, are doing fairly well.

After her husband's death, VI 465 became a harlot and acquired syphilis, which she not only entailed on her children, but spread to many others. During this period, she had three illegitimate children who died from neglect and syphilis. She then transferred her affections to VI 466, a neighbor. This man has an epileptic wife whom he ties to a chair when he wishes to leave the place. VI 465 has one bastard girl, VII 448, by this man. This child is now syphilitic. For the past 4 years this family lived in a barn, one half used for pigs, the other for the family.

VI 467, sister of the foregoing, is a woman of more intelligence and ability. She is quite proud and refuses to own relationship with the more degenerate member of the family. She is married and has four children, average in school ability and now working in factories.

VI 470, the youngest child of Nathaniel and Hepsy, is a coachman by occupation. He has a retiring nature and is a steady worker, is married, and has one son, now 13, who is in grade 3 at school.

Returning to the main line, we take up Gilbert, V 180, son of Alan. He was a ne'er-do-wetl and never had any schooling. Upon his return from the Civil War he lived with a cousin, Esther, V 399, of Effie blood. This couple received help from the town for 3 years, and a daughter who died was buried by the town. Esther died and Gilbert then cohabited with Ion, V 325, another cousin. Ion, a descendant of Delia, had been married before and had two children living. Gilbert and Ion were very poor, lived from hand to mouth, and received much help from the town.

VI 472 was an illegitimate son of Gilbert and Ion. He was semi-industrious, mentally deficient, ignorant, and tubercular. He married VI 473, more capable and active mentally than himself. He eventually died of tuberculosis, but not until they had had six children. His wife then 
became a prostitute and associated with very dissolute persons in Z, where she was then living. She was arrested and convicted of disorderly conduct, but sentence was suspended on condition that she leave town, which, however, she did not do. She placed three of her children in an orphan asylum at this time and kept one with her (two were dead). The oldest living child of VI 473, VII 458, after being in the Children's Home for some time, was placed with a cousin. At the age of 14 she is a shy, quiet, retiring child, much afraid of her foster parents. She has attended school but little. VI 473 now has her three children home with her and all of them are doing average work in the schools. The family has received help from the town and with what the mother earns by washing is not in want.

Gilbert's brothers, Riley, V 182, and Roland, V 184, are both semi-industrious and easy-góing. Each has acquired a little property and has married, but they have no children.

Mary Jane, V 186, the next child of Alan and sister to Gilbert, is now 64 years of age. She was a prostitute in her mother's brothel when young. She soon secured a common-law "husband," with whom she lived for 40 years. She is a hard-working woman and, by care and foresight, has provided herself with a good home, which she owns. A few years ago she had a paralytic shock and now exhibits a marked mental defect. Jesse, V 187, her husband, has had the same position as a teamster for many year's. One of their three children is a chauffeur and is doing well, while the two girls were married several times, but otherwise little is known of them.

Helena, V 188, was the next child of Ellen and was illegitimate. She was a harlot and had an illegitimate child, VI 482, who in turn became a harlot. Helena is dead; it is not known where her daughter lives.

Hetty, V 190, is the next daughter of Ellen. This person is not mentioned by Dugdale, although she was older than her brothers Reuben and Ulysses, who are mentioned by him. Hetty was born in 1853 . She has never had any schooling and, though now not mentally active, she has a great deal of self-respect and has tried always to do well. Her husband Joseph, V 191, can neither read nor write, but is one of the best brick-burners up and down the river. Notwithstanding this he receives small wages and these irregularly. He tries to be a decent citizen.

Joseph and Hetty had twelve children. The first, VI 484, is a laborer in a brickyard and has acquired a little property. His only daughter, VII 469, now 16 years of age, was very "stupid" in school and incapable of learning. She is now immoral.

VI 485, the next child of Hetty, was incapable of doing average grade work in school. She left to go into the cigar factory, where she remained until she married. She is capable in house matters, and is bringing up her children well. Her liusband, VI 486, is a laborer and earns fair wages. VII 470, aged 13, the only one of the children old enough to attend school, is in grade $6 \mathrm{~B}$. She is mentally incapable of doing average work. She tries hald, but is unable to keep up with those of her own age.

The third and sixth children of Hetty died young.

The next child of Hetty, VI 488, was more capable in school than her next older sister, but after leaving and while working in the cigar factory was a harlot. She married VI 489, a teamster and a good worker; but some- times intemperate. 'They had two children: the older, a girl, is at 14 in grade 6 at school, and although retarded in years is doing goorl work; the other, a boy, VII 475, is not doing as well in school.

VI 490 , the fifth child of Hetty, was in service, became pregnant, and died soon after childbirth, leaving one child, VII 477, who is now with her grandmother, Hetty. 'This child, who is neat and quiet in appearance, is nentally slow and can not learn in school. Her father was reputed to have been an alcoholic.

The next in this fraternity, VI 49:3, died at the age of 21 of tuberculosis.

The eighth, VI 494, born 1886, was a harlot and worked in a factory until she was 22 , when she married. S'he has now become reputable and has two young children.

VI 496 was not very "bright" in school. At 18 he married a girl of 15 . He is a hustler and makes sometimes as much as $\$ 30$ a week. He has two young children.

VI 498, now 23, was the next child of Hetty and Joseph. She was not inclined towards books, worked in factories, is reputed to have been immoral, and has recently married.

The next child, VI 500, was incapable of doing average school work and soon went to work in a factory. She, too, is married.

The last child of Hetty, VI 502, is a neat, quiet-actioned child. She is now at the age of 15 in grade 6 in school and is unable to progress further, as she can not reason for herself. She tries hard to get along.

Reuben, V 193, a brother of Hetty and son of Alan, was born in 1857. He is spoken of by his teachers as having been mentally dull and slow. He is a farm laborer and has never been able to keep a position any length of time. He has wandered here and there wherever he thought he might secure work. He has never accumulated anything. He has a quiet, retiring disposition. His wife, Mamie, V 192, comes from a family much higher mentally than Reuben's. Her father was a dentist and was intelligent and bore a good reputation in the community in which he lived. She has two brothers, storekcepers, and one brother who is alcoholic. Mamie is energetic, capable, and has brought up her children well. She has three girls and one boy matured and living. The three girls attended country school and did average work. They are now neat, quiet, and refined in appearance.

The oldest, VI 504, is rather reticent, but holds herself well. She is married to an artisan and has one child, VII 482, aged 14, who is accurate and careful, though slow in her school work.

VI 506, the next child of Reuben and Mamie, was slipshod, but worked regularly and tried to do well by his family. He has two young children living; both do very well in school. He is now dead.

Reuben's third child, VI 507, is more active and forward than her older sister. She married a prosperous farmer and they have three children of good mental ability.

The next son of Reuben, VI 509, is an uneducated, steady-going farm-hand and is doing well.

The last child of Reuben, VI 511, has always borne a good reputation, is mentally and physically active; she married a farmer and has two small children.

Ulysses, V 194, the last child of Alan and Ellen, is a semi-efficient, ignorant, intemperate, licentious man. He works "by spells" and has always been poor. He is supposed to have been married to Lisle, V 195, who, before she met Ulysses, was married and had several children. 
Among these children was VI 409, who married into Ada blood as deseribeck on page 22. Although reputed to have been inarried to Clysses, exact eonfirmation of this eould not be secured. She is a deseendant of a family noted for its thieves anr prostitutes. She was mentally mueh stronger than Ulysses, but was lazy and eared little about her personal appearance or that of her ehildren. She is now dearl, and Ulysses lives in squalor, filth, and poverty with his daughter, VI 513. Ulysses has been arrested several times for minor offenses. At 19 he was sent to jail for 30 days for assault and battery; at 30 he was fined $\$ 5$ for assault while intoxicated. In 1909 , in eompany with other Jukes, he was sent to jail for 5 days for using indecent language. Ulysses and Lisle had seven children.

The first, II 513, born 1885, was very defieient in sehool work. At 15, on the eharge of being a prostitute, she was sent to the State Training Sehool for Girls. Soon after being chischarged from the institution, she married a seeond cousin, VI 867, of Effie blood. They had two sons who survived infancy. One, VII 492, is doing very well in sehool, and is a bright, quiek-acting boy. VI 513 and her husband have separated and she is now eohabiting with VII 21, the widower of VII 20, of Ada blood. She is slovenl y and lazy; a slattern. She is now keeping house for her father and the house is in a very dirty and negleeted eonchition.

VI 515, her sister, is mueh similar to her mentally. She has always been a prostitute and is now cohabiting.

The third ehild of Ulysses, VI 517 , born 1888 , was very "stupid" in sehool and almost incapable of learning anything. At the age of 20 he cohabited for some time with a girl of 17 , who left him. At 22 he was sent to jail for 5 days for fighting with his half brother, VI 409, both being drunk at the time. For the past 3 years he has been living with a woman, VI 518, and her three children on a eanal boat. This woman left her husband, who provicled her with a good home, to be with this man, who can earn barely enough for feeding, to say nothing of clothing, a family.

VI 519, also, was unable to learn in sehool and is now a semi-effieient laborer. He is intemperate and very poor. He married his cousin, VI 413, as describerk on page 22 .

The two youngest sons of Ulysses, VI 520 and VI 522, are both married. They are of the same type mentally as their older brothers and so no description is necessary.

We will now take up the deseription of Alan's brother, Austin, IV 40, and his offspring, a group as uniformly deficient and undesirable as ean be found in the whole Juke family. Austin was born in 1811. He is reported by Dugdale as a quadroon. An old man who knew him well deseribed him as "honest and fair-minded but undeveloped." He had a "likeable disposition." He was temperate, a steady worker in a brickyard, but was always very poor. He married a cousin, Elsie, IV 166, sister to Ellen, who married Austin's brother, Alan. At 52 Austin enlisted in the ('ivil War and later received $\$ 1,000$ bounty money, which he soon lost. At 57 he was in the eounty jail 7 days for vagrancy. He eould neither read nor write and died poor at the age of 93 . His wife, Elsie, was born about 1813. She was a harlot before marriage and had a bastard son, Ephan, V 414, born by the roadside in 1828. Ephan and his descendants are described on pages 3 and 45. Six years later Elsie had another bastard, Everett, V 416 . He was a basket-maker and, though the records show he was receiving much outdoor relief, at the same time he was acquiring property. He married Mareia, IV 93, but died without posterity. Elsie married Austin about 1843 . In the following 25 years this couple reeeived mueh outdoor relief from the town. Elsie was spoken of by Dudgale as lieentious and vagrant. She was also a harlot after marriage and was very ignorant. This pair had four legitimate ehildren: Inez, Jonas, Mick, and Vergil.

Inez, V 197 , born 1844 , has been a harlot nearly all her life. She acquired syphilis, which she transmitted to Napoleon, V 196, her first eonsort, by whom she had one bastard child. Napoleon deserted her before the child was born and she and her child wandered around the eountry for several years, begging here and there. She did well at housework, but her bad habits precluded her holding a position for any length of time. At the age of 41 she had a bastard ehild by a man with whom she had been living for several years. Inez ean read and write, has a good memory, and is mentally rather aeute. She is a great talker, but her mind runs to nothing but vulgarity. She has always been very poor and is even now asking for help from the Charity Organization. The first son of Inez, VI 526, was born in 1868. He inherited syphilis from his mother. He is a lazy, ignorant, inefficient man. He is a laborer, but is employed only a small part of the time. He lived for some years with VI 525, who previously was married to his eousin, VI 531; one selling her to the other for a pint of whisky and 50 cents. The new eonsort and VI 526 lived together for some years and had six ehildren. The woman then deserted her children, leaving them to starve for several days, when they were found by the poormaster. She aequired syphilis from her eonsort and was operated on for uterine and ovarian disease following it. She is now cohabiting with VII 617 of Delia blook. Her five living illegitimate ehildren are as follows:

The first, VII 495, now 15, was sent to the Children's Home at 11 years with her four brothers and sisters. In school at the Home she was dull and eould not learn. At housework, a thing she eould do with her hands, she was very eapable. She is a well-behaved child and has now been placed in a private home.

The seeond, VII 497, aged 12, did average work in sehool and also is well behaved. She has also been plaeed out.

The third, VII 498, aged 10, gave a mental age of 8 by the Binet test at 8 years of age. He is very shy and slow in aetions.

The fourth, VII 499, now 8 , tested mentally 6 by the Binet test at 6 years of age.

The fifth, VII 500 , now 6 , was nearly frozen to death at the age of 2 when the ehildren were deserted by the mother. Following that she was unable to walk for some time.

The eost to the town and society for the support of these five children in the Children's Home for the year 1911-12 was $\$ 701$. As these ehildren are gradually being placed in free homes, the cost lessens, but the total expense to the town for the care and support of these children has been to date approximately $\$ 1,800$.

VI 527, the other child of Inez, was born in 1885 . He is ignorant and mentally undeveloped. He is a good worker, but otherwise slow and unable to comprehend matters. He acquired syphilis from his mother, is licentious, and in 1912 was arrested in eompany with VII 24 for disorderly eonduct. The latter charged bastardy on him, although another was reputed to have been the father 
of the child. 'The court's ease was droppord when lie consented to marry the girl. 'The child was born later. 'The two are now living with his mother, Inez, and, needless to say, are in dire poverty.

Jonas, V 200, the brother of Inez, was an ignorant, licentious wanderer. He cohabited for a short period with Rhoda, V 199, a sister of Leroy, who married Mercy, $\mathrm{V} 156$, of Ada blood. This girl became pregnant and they had one child, VI 528, who died of tuberculosis at the age of 17. 'The mother died soon after the birth of the child and Jonas then married Etta, V 387, his first cousin. She had a better mental capacity and was more active than Jonas, but in spite of that was a wanderer, semi-industrious, and licentious. She had a bastard child before marriage. This child died young. V 387 had two legitimate children by Jonas, both boys.

The first, VI 529, can neither read nor write and is mentally defective-an imbecile. At the age of 33 he broke into a store and was sent to State prison for 4 years and 7 months for burglary. He lived with VI 530, a member of a degenerate family. 'These two were beggars, wandering here and there over the country, stealing what they could not get by begging. Both were intemperate. The woman frequented houses of prostitution and submitted to unnatural practices. One night, when she left the brothel to go to her hovel home in the mountains near by, she was in an intoxicated condition. The next morning she was found frozen to death by the roadside. Just previous to this her "man" had been sent to jail for 60 days for vagrancy.

VII 504, the second child of this couple, frequented houses of prostitution with her mother. She was arrested, sent to a reformatory for women, but was returned as being of too low a grade mentally to be benefited by that institution. Upon this she was sent, at the age of 18 , to the Custodial Asylum for Feeble-minded Women. She is costing the State of New York $\$ 125$ a year for her support in this institution.

The oldest child, VII 502, is now 26 years of age and is a mentally defective prostitute who has for years frequented brothels. Recently she tried to secure a license to marry her uncle, VI 531, although he has one legal and one common-law wife living. The license was refused, not on the grounds that both parties were feeble-minded and closely related to each other, but because of the man's previous marriage. V1 529 had two other children, who died young.

VI 531, the second offspring of the consanguineous mating of Jonas and Etta, was born in 1875. He is called "Lazy Bob." When a young fellow he was sent to a reformatory for burglary. He married VI 525, but sold his wife to his cousin, as described before. He then lived for 11 years with a cousin, VII 19, having four children by her, described previously under Ada. He received much help from the towl during the time he lived with this last woman. He has also been arrested several times for minor offenses and sent to jail. Since he separated from the last consort he has wandered here and there, working as a farm laborer and a stonecutter. He has recently attempted to marry his own niece. He is very intemperate.

Mick, V 202, a brother of Inez and Jonas, was born in 1845. His home, as found by the investigator, is the cabin of an old canal barge, removed from the boat and placed on the edge of a river about 30 feet from its bank. It rests only about 2 feet above the water-line. It is about 9 foet wisle and 25 feet long. One onters throngh a doorway at one end by deseending several steps and at the same time bending double in order to clase the low door-opening. Another door immediately opens into the house proper, which ronsists of two rooms, living room and bedroom. There are several snall windows in the living room. Besides a wall table and miserable stove, there are two or three dilapidated ehairs. 'The bedroom has no windows, but is lighted from the living room. There are two bunks, one above the other, in ship fashion. Tpon the investigator's first visit to this place, after entering, he inquired of a dirty barefoot hag who conducted him im, where Mick was. A gruff voice from the top lounk answered, "Here I am, what do you want?" After aceustoning himself to the darkness of the bedroom, the writer perceived a large, husky man with a heavy beard, lying in the bunk, fully dressed, and smoking a pipe. He was very grandiloquent in his actions and to the writer's great amusement at first denied relationship to his sister Inez, who had told all about him only the day before. He said his father and mother were a Mr. and Mrs. "Q," and mentioned a name high in the social life of the county. When questioned mimutely about Inez he said, "Ol, she's some relation to me!" At 25 years of age Mick lived for some time with Vera, V 201, a harlot, who ran away from him. He then consorted with a distant cousin, Libby, V 335. This mating was brief, as Libby died of childbirth with her first child. His present mate is Hulda, V 203, a member of a fairly respectable family. At one time Hulda bore a good reputation, but since she las lived with Mick she has degenerated into a careless, filthy, foulmouthed individual. When seen she was dressed in a single wrapper; her fect were bare and frightfully dirty. Mick and Hulda have three children.

The first, VI 534, ignorant and untrained, is married to a feeble-minded woman and has two small children. He works at anything that may come his way and is very poor.

The second, VI 535, lives at home with his parents and goes fishing when the mood takes him. He is unmarried and "supports" his parents. He is also mentally deficient.

The third, VI 536, was a mentally refective harlot, but is now married and has two small children.

Vergil, V 204, the last child of Austin and brother to Mick, was reported by Dugrlale as being a "very bad boy." After he grew up he seems to have been less vicious. He was a hard worker but never saved anything; was densely ignorant and "amounted to nothing." He first married Leal Maria, V 333, a sister of Libby who married Mick. Leah Maria had been married previously, but was divoreed and had since been a harlot. She was very ignorant. She died of consumption, neglect, and abuse at the age of 38 . She left two children: VI 538, a rather industrious, steady, but ignorant boy; and a girl, VI 539, who died of childbirth at the age of 16 . After Leah Maria's death, Vergil lived for ten years, until his death, with Jane, V 205, an ignorant, talkative, mentally deficient harlot. Jane and Vergil had two girls and a boy, who now range from 18 to 14 , are underfed, anemic, and in want. They are also very deficient mentally. The oldest girl, VI 511, has recently sworn out bastardy charges against a certain man who filed a bond for the chilk's support.

Ada's fourth and list legitimate child was Aleene, III 6, temperate, but lazy, a harlot, and without property. She married a mulatto, who was a slare, Grant, III 7, but had no children. 


\section{DESCENDANTS OF BELL JUKE.}

\section{(Chart 3.)}

Bell Juke was born about 1760 . She was a farm laborer, a harlot before marriage, and had four illegitimate children, three black and one white. She was not industrious, had no property, and received outdoor relief, but was temperate and not criminal. She married Bruce, II 4, and had four legitimate children. She died in 1832. Bruce, according to Dugdale, was "a common laborer"; revolutionary soldier; not industrious; no property; received pension; also outdoor relief; not criminal; temperate."

Bell's first child (illegitimate) was Burton, III 9. He was a mulatto, temperate, industrious, intelligent, manly, "the best of his generation," and he acquired property. He was twice married and died about 1820. His first wife was Hazel, a mulatto, temperate, industrious, and also healthy. Burton had two boys and three girls by Hazel, but the children did not do so well as the parents. By his second wife he had one boy and one girl; the former was frozen to death while drunk. All these children inarried negroes. Dudgale did not trace them further, and it was therefore impossible to carry on the study of their posterity.

The second child of Bell was Bertha, III 12, also illegitimate. She was a mulatto, a harlot before marriage, temperate, but not industrious. She married an industrious, intemperate mulatto and had numerous children who were not traced by Dugdale. It appears that he intended at some future time to make a more exhaustive study of these threads, but his early cleath probably prevented this.

Bob, III 14, the third illegitimate child of Bell, was a "mulatto; not industrious; laborer; acquired property and sold it; temperate; adopted a daughter, Bessie, of his half brother, Bruno, and gave her a fair home." He married Maria, III 13, a reputable white woman, but this pair had no children.

Brown, III 16, the fourth and last illegitimate child of Bell, was white. He was industrious in youth and acquired a farm of 60 acres. He could read and write, but was licentious, and in his old age was an habitual drunkard and lost his property. At 66 he received outdoor relief for three years, and at 69 died of debility and was buried by the town. He married Myra, of whom nothing is known, and had seven children by her: Uriah, Hans, Blandina, Isaac, Israel, Benjamin, and Betsy.

Uriah, IV 54, was apprenticed to a farmer when a boy. He could read and write, was inclustrious, and acquired a farm. He married Hortense, IV 53, ignorant but of good repute. This couple have left the county of $Z$ and have gone to Pennsylvania, where they have bought land. They have children, but they were not traced by Dugdale.

Hans, IV 56, was a man of good character, although slightly intemperate. He was a farm laborer and industrious, but never acquired any property. In his old age he received help from the town and had town burial. His wife, Gretel, IV 55, was industrious and had a good reputation. As in the case of Uriah, Dugdale did not trace the children of Hans.
Blandina, IV 57, was of good repute. She married Gideon, IV 58, a somewhat industrious laborer, who had no property, was intemperate, and who died of an overdose of opium in 1855. 'This couple had three children: Lois, Phyllis, and Naomi.

Lois, V 210, "of good repute; basket-maker; read and write; recipient of outdoor relief;" married Wright, V 209, a stonemason and soldier.

Phyllis, V 212, could read and write. She was a harlot and cohabited with different men. All trace of her is now lost.

Naomi, V 213, "good repute; basket-maker," married her cousin Al, V 21, (for' children see chart 1). 'She had much town help.

Isaac, IV 59, brother of Blandina and son of Brown, was a laborer. He was sent to State prison for $2 \frac{1}{2}$ years for burglary in the third degree. He died of syphilis in a hospital. His wife, Rebecca, IV 60, was syphilitic and died in a fit (probably epileptic). They had two girls: one an ignorant harlot with constitutional syphilis, who died of syphilis, and another who died young of constitutional syphilis and acquired syphilis.

Israel, IV 61 (brother of Isaac), was a laborer on the canal and, although he never acquired any property, he never received any help from the town. He was married twice and was drowned on the morning after his second marriage. His first wife, Ursula, IV 62 , had a bastard child before marriage and later was in the county jail. Ursula had two children by Israel, as follows:

Joshua, V 216, "laborer on canal; 1874, attempt at rape, case not pressed ; rough, dangerous man; unmarried."

Zenobia, V 217, has married. There is no knowledge as to her whereabouts.

Benjamin, IV 63, brother of Israel and Isaac, is described by Dugdale as follows: "Teamster; at 38, outdoor relief, 3 years; 44, soldier; bought house and lot with bounty money, and gave it to his wife; 45 , outdoor relief, 2 years; 50 , outdoor relief, 5 years; 55 , county jail, 90 days, charge larceny, acquitted; ignorant; rather honest; can not read and write." He is spoken of as having been better morally than mentally. He married a cousin, Abigail, V 67 (see chart 1 for children). After his wife died Benjamin placed two of the children then remaining at home in a Children's Home, and then lived with a woman. At the age of 58 he was in the poorhouse for two years with a broken wrist and again at 61 for one year. He died at the age of 71 .

Betsy, IV 64, the last child of Brown and Myra, and granddaughter of Bell Juke, was a harlot who acquired syphilis. She received town help and was in the poorhouse for one year. She cohabited with Leslie, IV 65 , the reputed father of her two children. Leslie had served a term in State prison for burglary, was syphilitic, and later deserted Betsy and married. Their two children were:

Idella, V 220, at 10 in the poorhouse with her mother and sister for one year; married; now dead.

Bertie, V 221, who at 8 was in the poorhouse for 1 year, but was subsequently taken by his father and trace of him has been lost. 


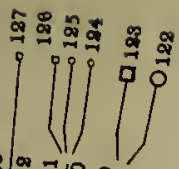

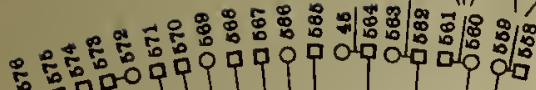

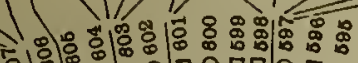
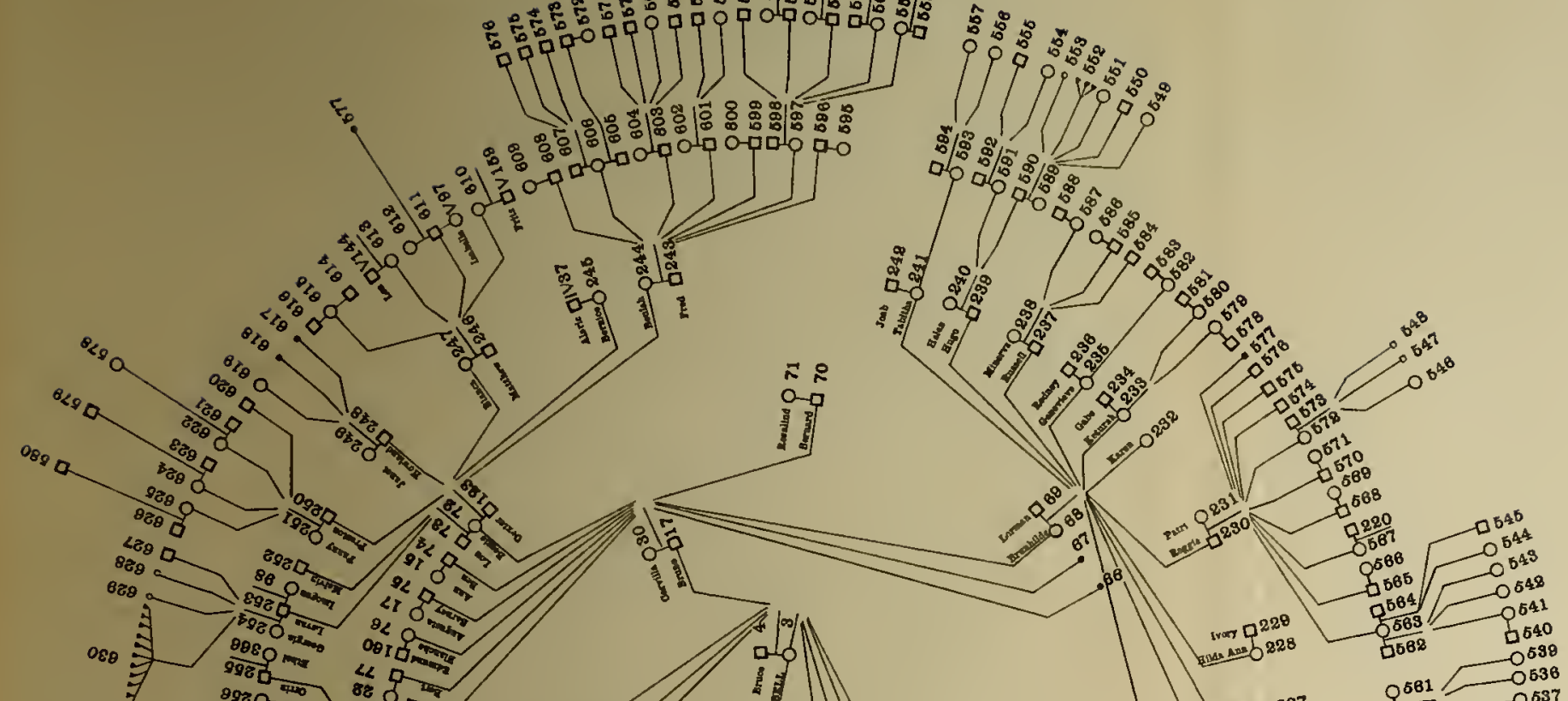

088

080

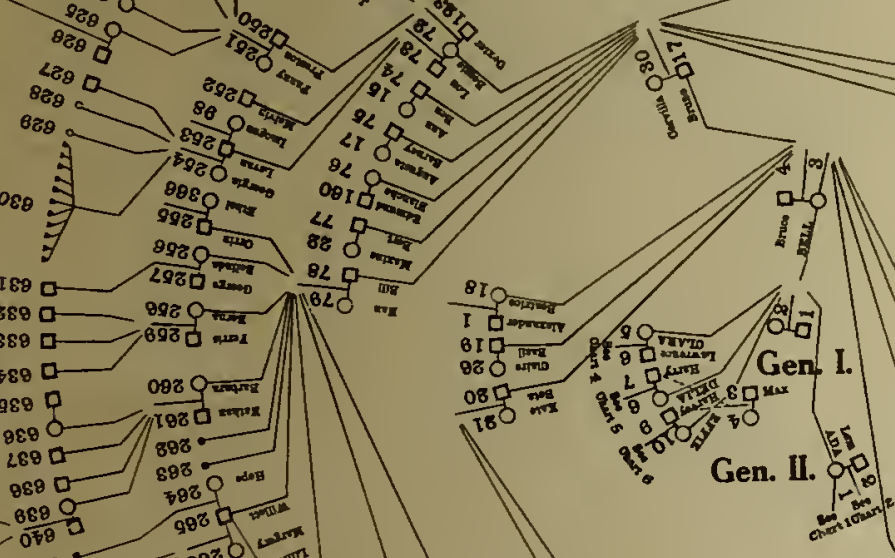

(1,

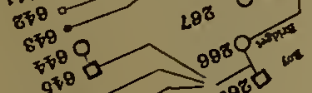

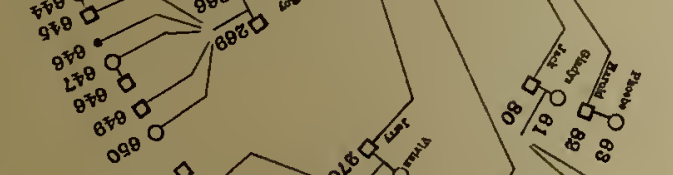

Gen. III

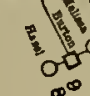

Gen. IV.

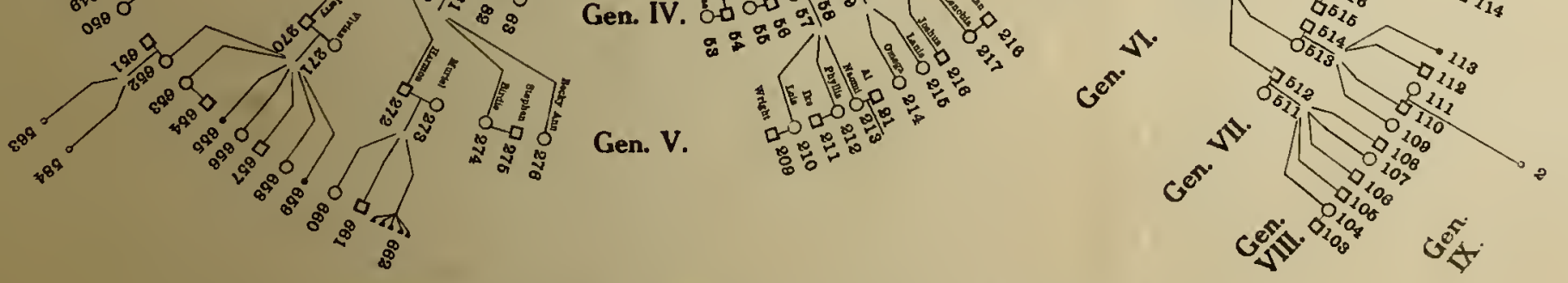

Chart 3. Genealogical Tree of the Descendants of Bell Juke, as recorded in 1915.

Large squares indieate males over age of five; large circles indicatc females over age of five; small squares indicate males under agc of five; small circles indicate females under age of five.

Solid equarcs and circles indicate dead before age of five.

solid trangles indicate those dying in infancy sex unknown, and miscarriages. 

Bell's fifth, and first legitimate, child was Bruno, III 17, a farm laborer, a good worker, and recalled by an old resident of $Z$ county as "an inoffensive creature, slightly deficient mentally." He was healthy, but somewhat intemperate and never had any property. He could read a little. He married his cousin, Carvilla, III 30, a daughter of Clara Juke. Carvilla's own history is not known. Bruno died at the age of 80 . Bruno and Carvilla had ten children: the first two died of cholera in 1837; the others were Brunhilde, Bermard, Bessie, Ben, Barney, Blanche, Bert, and Bill, grandchildren of both Bell and Clara Juke.

Brunhilde, IV 68, is given by Dugdale as "bawdy house; harlot; syphilis; lazy; habitual drunkard; no property; at 37 , outdoor relief, 1 year; 40, outdoor relief, 1 year; 60, died, 1869." She married Lorman, IV 69, who was a loafer, an habitual drunkard, and who, with his wife, kept a brothel with his own daughters as inmates. He unlawfully made whisky in his home. He never acquired any property, but received help from the town for many years. He was not ignorant, but was considered mentally deficient. At the age of 58 he shot and killed a man who was trespassing near his home and was sentenced to State prison for 3 years, for murder in the third degree. He died in 1884 at the age of 77 . Lorman and Brunhilde had eleven children: Rosa May, Lize, Renia, Hilda Ann, Reggie, Karen, Keturah, Genevieve, Russell, Hugo, and Tabitha. All these inherited constitutional syphilis from their mother and each girl was a harlot.

Rosa May, V 223, was intemperate like her mother. She learned to read and write a little as she grew older; she never possessed any property and has always been poor. She lived with Noah, V 222, who is recorded by Dugdale as criminal, but I do not find his name in the court records, and old residents informed me that he was never in trouble. However, he comes from a family characterized by licentiousness. He was industrious, slightly intemperate, but not vicious, and was always neatly dressed. He had six bastard children by Rosa May, all of whom died in infancy except one boy, VI 545. After Noah died Rosa May lived with Guy, V 224, who is reputed to be the son of a man who, after he became a millionaire, cast off his mediocre wife and children, married a woman of his own class financially, and is the ancestor of a family which numbers among its members some very wealthy people of to-day. Rosa May is still living. She is a tall, thin woman, 83 years of age, broken down by asthma and heart disease. Although ignorant, she is mentally active and has a pleasant, talkative nature. She lives in two rooms and keeps them and herself neat and clean. For many years she has been supported by her grandchildren.

Rosa May's son, VI 545, was a capable veterinary surgeon and for many years was respected in the community in which he lived (a city of 25,000 persons), about 40 miles from the Juke region. He became intemperate as he grew older and gradually associated with low and vicious characters. He had by his first wife, VI 544, a woman of good repute, five children, two of whom died in infancy. After her death he cohabited for some time with a dissolute woman. He was a wanderer in later life and died poor at the age of 64 .

VII 512, the oldest living child of VI 545, is an industrious, steady-going fellow, who married a woman who is his equal mentally and socially. They have five children, three boys and two girls, who are neat in appearance and well behaved, and whose school ability is only slightly below the average. All of them are good physical specimens.

The second living child of the veterinary surgeon is a girl, VII 513, who is reputable and industrious. She married and has three children: one girl, a store clerk of good repute who has helped support her nother since the death of her father; a boy of good make-up, who married, and has one child which forms one of the ninth generation of the Juke family; and a boy who is a stearly-going, industrious young fellow.

VII 516, the third living child of the veterinary, is a good, intelligent girl who has recently married.

Lize, V 226, a sister of Rosa May, was an habitual drunkard, a harlot, and kept a brothel. At the age of 43 she committed an assault and battery and was in the county jail for 4 months. She cohabited with Union, V 225, a man of good education but idle and intemperate. He inherited some property, lut soon lost it, and then, at 49 , received help from the town for several years. Lize and Union had nine children, five of whom died in infancy.

The oldest living child, VI 553, born in 1849 , was arrested at the age of 18 , while in her parents' brothel, for being a prostitute. Her case was dismissed. Soon after this she married an intelligent, industrious, but intemperate engineer. This man always earned good wages, and his family, consisting of seven children, was always well clothed and fed. Some years ago he died. The wife has little education, but is neat, now bears a good reputation, and is supporting herself by taking boarders. Their children are as follows: male, aged 40, troublesome and vicious in school, of ordinary mental ability, now a foreman in a brickyard, married to an intelligent, industrious woman, and father of two children, one, a boy, now 15, who is troublesome, lazy, and inclined to steal, the other, small; a female, aged 35 , without much schooling, neat and chaste, now married; a female, aged 33 , of ordinary school ability, neat, industrious, and moral, married, and with three small children; two males, about 30 and 28, capable steam engincers, unmarried; female, aged 24, of good repute and married, with trace lost; and a female who recently died of tuberculosis at the age of 18 .

The second child of Lize and Union, VI 556, a male, is a semi-industrious, intemperate ne'er-do-well, who has lived with two different women. By one he had a child which died in infancy.

The third child of Union and Lize, VI 558, is a good worker, a brickyard laborer, who has always provided well for his family, although he is very intemperate. His wife, VI 559, a member of the same degenerate family as Lisle, V 195, who married a descendant of Ada, was sent to the House of Refuge at the age of 12 for vagrancy, a term used at that time for prostitution. She is reported as having done well on her discharge. She is neat in her personal appearance and takes pride in her home. She has three children. The oldest, a boy, VII 531, was mentally slow and did very poor work in school, is now a laborer, was licentious, and has recently married a prostitute by whom he has two living children. He has two sisters, VII 533 and VII 534, who were both slow, but who tried hard and did average school work with a great deal of difficulty. They are neat, church-going girls, with molest manners, and are both working now in a factory.

The last child of Union and Lize, VI 560, is a steaniboat engineer who can earn good wages. He is married and has 
five children: a boy, aged 20, a good worker, but shuggish in school and with deficient causation; a boy, aged 18, who left school at the age of 16 , while in the seventh grade, to go to work; a girl, moral, carcful in appearance, but mentally inert, and inattentive, who, at the age of 14 , can not kecp up with her ckass in sixth-grade work; a girl, aged 12, much like her older sister; and finally a girl of 9 who seems to be mentally incapable of grasping school work at all. These children are in a home where there is plenty of food and clothing. Four of them, at my suggestion, received special attention on the part of their teachers and yet they could not do averagc work in school during the thrce years under observation.

Renia, V 227, sister of Lize, whose descendants have just been described, was an idle harlot who has been in the county jail for vagrancy. She never married.

Hilda Ann, V 228, sister of Renia, was a harlot and an habitual drunkard, who kept a rum shop and brothel. She was indolent, the recipient of poor relief, and also was in the poorhouse. She cohabited with Ivory, V 229, an intemperate, iclle pauper, who died of syphilis acquired from his consort. Hilda Ann had no descendants.

Reggie, V 230, was an ignorant, idle drunkard. He enlisted in the Civil War, deserted, changed his name, entisted again, this time in order to get more bounty money, and received a soldier's pension up to the time of his death. At the age of 30 he was in the county jail for assault and battery. He never worked, and woukd go to any means to secure money for whisky. He died of cerebral hemorrhage at the age of 72 . His wife, Patri, T 231, was immolal and has been a beggar all her life. She can neither read nor write, and never" "amounted to much." She is now living with her son, VI 574. She has had ten children.

Patri's oldest, VI 563, is a harlot, and, after being deserted by her husband, who was sent to State prison, she cohabited with another man. By her first consort she had three daughters, of whom nothing further is known than that they have been harlots. They have wandered from place to place, changing their names in each town, so that it was practically impossible to trace them. By her last consort she has two children, a boy and a girl, both young.

The sccond child of Patri, VI 565, is ignorant, but, though nearly ahways in an intoxicated condition, is a steady worker and has always provided well for the woman with whom he happens to be living.

The third child of Patri, VI 567, is ignorant, inefficient, and a harlot. She married her cousin, VI 220, a descendant of Ada and Bell Juke. Their chillren are described undel the husband (page 16).

The fourth child of Patri, VI 568, is a good worker and has fair intelligence. He has left the Juke country and is now in a large city, where he is doing well as a mechanic. He is married, but has no children.

VI 570, the next child, is much like his okler brother. He too has left the old Juke haunts and has done well socially. He also is married, but has no children.

The sixth child of Patri, VI 572, is an inefficient, idle, licentious, slovenly woman. She married a man much hike herself nentally and socially and they, with their three young children, live in a hovel on the hills.

The three remaining children of Patri are steady, industrious boys, who do not seem to be following the ancestral Juke traits to any great legree.
The last child of Patri, a boy, died in infancy.

Karen, V 232, a sister to Reggie, was a harlot and very poor. She seems to have had no posterity and is now dead.

Keturah, V 233, kept a rum shop and brothel and was herself a harlot. She was married, but was divorced by her husband for loose conduct. She then cohabited with Joab, V 242, a wagon-makcr, an idle and intemperate man, who deserted his fine wife and several children in order that he might live with this prostitute. He deserted Keturah in turn and later cohabited with her sister, Tabitha, V 241. Keturah had two bastard girls, of whom nothing could be discovered, as they are both wanderers about the country.

Genevieve, V 235, was a harlot; she had onc bastard girl, VI 582, who is also a harlot and who has gone away from the Juke region. Genevieve was capable at housework, which she did to support herself, until in later years she found that she could play on the sympathy of others to get what she wanted. She maintained herself in this way until she went to the poorhouse at the age of 69 . She had so ingratiated herself into the hearts of charitably inclined people of the town that they requested the superintendent of the poor to give her a special room at the poorhouse. She remained there three years, until her death.

Russell, V 237, brother of Genevieve and son of Brunhilde and Lorman, is an intermittently industrious, intemperate wanderer. He married a woman with much the same qualities and they have three children; the first is a make, an intemperate wanderer; another male is a guard in a reformatory and a man of good character, married; and the third is a self-respecting factory girl who has recently married.

Hugo, V 239, brother of Russell, was an intemperate, semi-industrious man, who married a woman of his own type in every respect. 'This pail had two children, a son and a daughter.

The son, VI 590, was a good, capable workman and once earned good wages as a painter. It is now impossible for him to secure any work on account of his intemperance. He has been arrested many times for drunkenness and has taken the pledge each time. He married an ignorant, mentally defective woman, who worked hard and tried to do well by her family of four children until her death during childbirth in the past year. The oldest of her children, VII 549, did average work in school, but left at 14 and has gone to work in a factory.

The second, VII 550, a boy, aged 13 (mentally aged 3 according to the Binet test), with partial aniridia, is known as the school idiot, and has as yet failed to learn how to spell even his own first name, which consists of but threc lettels; he should be in custodial care. There are two young children, both girls. Three children died at birth. The year before his wife died the man was arrested many times for non-support, but, on account of his intemperate habits, the solution of the problem of the support of the family has not been reached.

The daughter, VI 591, is morc intelligent than her brother and bears a good reputation for chastity. She is married, but at present does not live with her husband. Her oldest child, a girl, now 19, is neat in appearance, intelligent, and works in a factory. The son is a laborer and wanders here and there.

Tabitha, V 241, the last child of Brunhilde and Lorman, was boln in 1844 . At 16 she was sent to the county jail 
for vagrancy, the official term for prostitution. She has always been very poor and has received much outdoor relief. She is cross, irritable, and very sharp-tongued. She can read and write. After Joab deserted Keturah he lived with Tabitha as aforesaid. The latter had one child, but common repute has it that it is of unknown paternity. Later Joab was sent to State prison for rape on a young girl and here he died. 'Tabitha now lives with her daughter, VI 593. The daughter's husband, a barber, after consorting with prostitutes in low dives, finally stole all his wife's money and left town with a prostitute, and has never been heard of since. The wife is now an ill-tempered, mentally inactive woman who runs a boarding house. Her two daughters work in a factory, dress neatly, and bear a good name in the neighborhood.

Brunhilde's brother, Bernard, IV 70, was in jail at 59 for breach of peace and soon after that left the country. He was married, but Dugdale gives no further information.

The fifth child of Bruno and Carvilla, and sister of Brunhilde and Bernard, was Bessie, IV 72. She was brought up by her half uncle, Bob, III 14, until she was 18 years of age, and was reputable until then. Soon after this she married her cousin, Dexter, IV 123, a descendant of Delia. He was a poor and temperate laborer, who died of inflammation of the lungs. Dexter and Bessie had five legitimate children: Beulah, Bernice, Bianca, Howland, and Preston. After Dexter died Bessie cohabited with Lon, IV 73, a loafer, an habitual drunkard, and a criminal, and had two bastard children by him: Melvin and Levan. She was the recipient of outdloor relief during practically all of her married life. Dugdale reports her as "intelligent with excellent memory." In connection with this statement of Dugdale's, it may be said that in this particular group of the Jukes there are many individuals, most of them women, who show a good memory for dates and past happenings to a remarkable degree. It must be remembered that in a hovel region, where reading is little practiced and newspapers are almost unknown, personal incidents or reminiscences occupy a large part of the conversation and thought. Bessie and both her husbands are now dead.

Bessie's oldest child, Beulah, V 244, who was a woman of good repute, was industrious, temperate, not criminal, and could read and write. She married Fred, V 243, "laborer; soldier in war; temperate; read and write; a good citizen; inherited property." Fred was of French extraction and brought good traits into the Juke strain. Beulah had seven children.

VI 596, the oldest, became a laborer and mentally was not as active as some of the others.

The second, VI 597, was an industrious woman of good repute, with some schooling. She married a laboring man and had five children by him, all of whom finished school sooner or later with more or less retardation.

The oldest child of VI 596 is a girl, VII 559; she is of good repute and has worked in a cigar factory to support herself and two little children since her husband deserted her.

The second, VII 560, is a semi-industrious woman, married to a very intemperate man who spends all his wages in drink, and is fast making herself a pauper by seeking private aid from lier more fortunate relatives. She has three little children still too young to go to school.

The third, VII 562, is an industrious, steady young fellow who now owns a cigar store of his own. He is married to a spendthrift woman and lass one young child.

The fourtl, V'II 564, a good worker and industrious as well as ambitious, is married to his cousin, VII 45, a descendant of Ada Juke. Their children are described under Ada (page 5).

The last one in this funnily group is a young fellow, VII 565 , about 19 years of age who is starting out in life well.

The third child of Beulah, VI 599, is a steady workman, has acquired property, and is a good citizen. He is married, but has no children.

The fourth child of Beulah, VI 601, was industrious and social in his behavior. He died some years ago, leaving a wife and two children, who have since disappeared.

The fifth, VI 603, has saved his money, now owns quite a little property and is a good citizen. He married an intelligent, moral woman from a eugenic family and they have four children, all of whom are mentally acute, very capable in school, neat in appearance, and social in their behavior. The oldest boy, VII 568, now at the age of 20 holds a responsible position with an industrial firn. The others are still in school.

The sixth child of Beulah, VI 606 , is a woman of little education. She has always borne a good reputation. Since the age of about 25 she has been deaf. About two years ago she was in a neighborhood quarrel and was arrested, but was discharged. Her first husband was a brother of Marie, V 79, who married a descendant of Ada Juke. This man died very soon after marriage, leaving her with one son, VII 573, who showed fair ability in school, is now working on a delivery wagon, and is social in his behavior. He has recently married. Very soon after the death of her first husband, VI 606 married an intemperate, lazy "good for nothing." He is a mason by trade, but what little he earns is spent in drink. Consequently his wife has to support the family, which she does by taking in washings. This she has done for many years past. This mating produced three children, all boys, who are physically lazy, mentally slow, and sluggish in their school work. The oldest of these is now 15.

The last child of Beulah, VI 608, owns a grocery store and saloon, has acquired considerable property, and bears a good reputation in the community. He is married, but has no children.

The second child of the consanguineous mating of Dexter and Bessie was Bernice, I 245. She was ignorant and never had any schooling. She became blind at the age of 30. She married Alaric, IV 37, a descendant of Ada Juke. Official records say that she had seven children, but she denied ever having had any. I heard from other sources that the only child of her's which lived had been placed in an Orphans' Home. At any rate, I could find none. The pair have been very poor and received town aid for many years, although her husband has received a soldier's pension. Although 74 years of age when I saw her, and completely blind, she was physically very active and garrulous, and had a good memory of past events, but was completely wrong in regard to dates. She was short in stature, thin, and had the typical physical make-up of a descendant of Bell. She died of old age in 1914.

Bianca, V 247, a sister of Bernice, was a harlot and very ignorant. She cohabited for many years with Mat- 
thew, Y 246, all intemperate, semi-industrious laborer. She was semi-industrious also. The pair received help from the town for many years. They had four chilctren.

The first, VI 610, more intelligent than the others and always considered reputable, married her cousin Fritz, Y 159, of Ada blood. They had two children, described under Ada (page 22).

The second child, VI 611, a strong, healthy fellow, but intemperate and only intermittently inchstrious, lived first with his cousin Isabella, V 97, of Arka blood, and has recently been cohahiting with a slatternly woman by whom he had one child which died in infancy. This woman is a plofessional pauper.

The third in this fraternity, VI 613, is an ignorant, mentally deficient, untrained, easy-going woman, who has tried to bring up her children as well as possible with the social handicaps she is forced to meet. She married a cousin, Len, V 144, of Ada blook.

The fourth child of Bianca, and the last in this group, VI 615 , is a prostitute, who has left the Juke region and gone to New York City, where she now is. Nothing of hel characteristies is known.

Howland, V 248, the fourth child of Bessie and Dexter, was an industrious laborer when young. He was a soldier in the Civil War and since becoming blind at the age of 35 has received a pension of $\$ 100$ a month. It will be remembered that his sister Bernice became bhind at about the same time. He now owns a comfortable home, worth $\$ 3,000$, in a nice section of a small city, and is much respected in the neighborhood. He married Janet, V 249, reputable and intelligent, who died some years ago. This pair had three children, all girls, two of whom thed very young. The other, VI 619, is a tall, well-dressed, exceedingly friendly young woman and very capable in every respect. She keeps an immaculately clean home for her father and is actively engaged in church work. She was formerly a teacher, but gave this up in order to take care of her parent. She is rather talkative and at times is inclined to exaggerate in order to impress her wit and humor upon the observer. She will give her last cent to any of her poor Jurke relations and at one time gave $\$ 50$ to one when he came begging for money to bury his wife. Although she helps these people, she is rather ashamed of hel connections.

Howland's brother, Preston, Y 250, was a cooper for many years. Like his brother, he enlisted in the Civil War. He married Fanny, $Y 251$, a woman of mediocre ability, with little education but considered reputable. Preston and Fanny, when first married, received help from the town for several years, but after this period, although they never acquired any property, they seemed to get along well. Since Preston's death, which occurred many years ago, Fanny has received a soldier's widow's pension. 'This pair' had four children.

The first was a boy, VI 620 , who was mysteriously assaulted and killed at the age of 20 .

'The second was a girl, VI 622, ignorant and loucltalking, reputable, but with an erotic nature, married to a storekeeper much older than herself and the mother of one child who was graduated from the high school at 19 and is erotic, "silly," and recently suffered an attack of tempolary blinkness following Bright's disease.

The third was a girl, VI 624, who married when young and had one child and, since her husloand deserted her, lias been doing housework.
The fourth, VI 625 , is reputable and of fair intelligence, is marrier to an intelligent citizen and is the mother of one boy now in high school, who is doing very good work.

The first bastard child of Bessie, Melvin, V 252, is a double-jointed dwarf about 3 feet tall. It is reputed that P. T. Barnum, the circus man, offered Bessie a large sum of money for Melvin, but the offer was refused. He is very intemperate, has a bad temper, and works at various things, but usually as a watchman. He has never married, has ahways been poor, and lives with his half-sister's daughter, VI 606.

His brother, Levan, V 253, a bastard child of Bessie, has ahways been a farm-hand, is poor, intemperate, and has never done well. He married his first cousin, Imogen, V 98, a descendant of Ada and Bell, and after she left him he cohabited with Georgia, V 254, a high-grade mental defective. She has had eleven miscarriages and three children who are alive. The oldest, a boy, VI 627 , was very slow and incapable in school, and is now working as a farm-hand. At one time Levan kept a young girl at his house, a relative of his wife Georgia. It is believed that he committed rape on this girl, but sufficient legal evidence could not be secured to prefer charges against him.

Ben, IV 74, a brother of Bessie, and son of Bruno and Carvilla, is the next under discussion. He was a "laborer; nearly blind; somewhat industrious; honest; no property; no outroor rehief; temperate; probably constitutional syphilis." He married his cousin, Ann, IV 15, and their descendants are kescribed under Ada.

Barney, IV 75, brother of Ben, was "laborer; somewhat industrious; no property; blind by injury; impotent; died of tubercular consumption, 1859." He married his cousin, Augusta, IV 17, but had no children.

Blanche, IV 76, sister of Barney, had a small shrunken lody like Bernice, V 245, and was blind from syphilis. She was ignorant, but of good repute and, luring her married life, received a great deal of poor relief. She married Edmund, IV 160, a descendant of Effie, and her children are described under Effie (page 42).

Bert, IV 77, a laborer, was the next in this fraternity. He married a cousin, Maxine, IV 22, a descendant of Effie, but she divorced him on grounds of impotency.

Bill, IV 78, the last of this family, was a coarse, ignorant, alcoliolic laborer. Although physically strong and healthy, he was below par in his mental development and had a weak moral sense. He ahways worked hard, but received sinall wages and at one time was helped by the town. He married Nan, IV 79, a coarse, shrewish, ignorant, but mentally active woman. Nan is a sister of Noah, V 222, who married Rosa May of Juke blood, V 223. After having had ten children by Bill, she left him in his old age and cohabited with another until her death. Bill died in 1887 at the age of 62 . Their children were as follows: Orrin, Belinda, Berna, Barbara, two who died in infancy, Willett, Bridget, Jerry, and Harmon. 
Orrin, V 255, the only one of the four sons of Bill and Nan who amounted to any thing, became a skilled mechanic and bore a good name for a Juke. He married his cousin, Ethel, V 366, of Effie blood, an ignorant, semi-industrious, easy-going, and essentially anti-social woman. Orrin died at the age of 35 , leaving three socially inadequate children described under Effie (page 41).

Belinda, V 256, the second cliild of Bill, was a harlot and worked in a factory. She was quiet in her dress and manner and to the casual observer did not seem to be mentally deficient. A prominent man, a principal of one of the schools of $Z$, who has known this particular family very intimately, states that with the exception of Orrin all the children of Bill were mentally defective. Belinda married a truckman of good repute and has one son considered average mentally.

Berna, V 258, was also a harlot and worked in a factory until she married Ferris, V 259, a man much older than herself but of fair mental and physical activity. Three boys were born to them. The first, VI 632, was of slightly below average school ability and at 18 is sluggish and without ambition. The second, VI 633 , who has a quiet nature, dropped out of the first year high school at 14, as he was mentally incapable of carrying on the work. The third, VI 634, is at the age of 13 in the sixth grade, and is slow and inaccurate in his work.

Barbara, V 260, was much like her sisters in social behavior before marriage. She married Nathan, V 261, and has left the Juke region. Little of her subsequent history could be ascertained, further than that she had four children.

Willett, V 265, was considered "half-witted" as a boy. At that time he had a pleasant, genial disposition if not crossed. When I knew him he was physically a nearly perfect specimen of the human race and he seemed to be keen mentally, but yet was unable to correlate cause and effect. He was always a steady worker, being a teamster most of his life. He was always temperate. At the age of 25 he, with his brother Harmon, then 18, broke into a barn, stole some blankets, and then, in order to cover their tracks, burned it. The two were subsequently arrested and sent to State prison for 8 years. Custodial care for these two would, in the light of events which followed, have saved society one murder and the birth of five children who died of syphilis in infancy. At the age of 32, soon after parole from prison, Willett was arrested and fined $\$ 5$ for assault. Previous to his first arrest Willett married Hope, V 264, and had one son by her which died in infancy. When he was discharged from State prison he found his wife living with another man. Soon after this he left the Juke country and went to a nearby State, where he lived for a few years as a peaceable citizen. He soon "took up" with Margery, V 266, a young woman, and had two children by her, one of whom died and the other, aged 4, is now living. While still living with Margery, Willett became infatuated with Lillie, V 267, a married woman with two children. Her husband opposed this liaison, with the result that Lillie and Willett plotted between them to kill the husband. Finally with her help Willett murdered him in a cruel and clumsy fashion. He paid the penalty of death for this crime and Lillie is now serving a life term for murder. It is estimated that the cost to the State for this one crime was $\$ 13,000$.

Lillie is a feeble-minded girl, born of feeble-minded parents. Her father's half-brother, of Indian descent, was sent to State prison for assault and rape on a young schoolteacher and died in prison. Lillie, at 14 , was taken into a good home, and given every opportunity to learn housework. Her sole interest at that time, however, was in the opposite sex. At the age of 17 she liad an illegitimate child reputed on good authority to have been the result of incestuous relations with her father. It was at this time that she married.

Bridget, V 268, sister of Willett, was an ignorant harlot. She married Roy, V 269, an ignorant, but steadygoing laborer, who has worked for the same person for many years. Bridget had five children: VI 645, a streetcar conductor, married, with one young child; a boy, dead; a girl of good repute and fair schrool ability, marricd to a man recently arrested for assault on a young girl; a boy, tubercular, who was sent by charitable people to Denver to recover his health, but who died; and a girl still young. Bridget died a few years ago.

Jerry, V 270, never had any schooling and is mentally below par. He is temperate and a steady though untrained worker. Jerry married Vivian, V 271 , at the same time that Willett married Hope. They lived together and had seven children. About 5 years ago Vivian deserted Jerry and, with her youngest daughter, now 14 years of age, has wandered here and there, the mother prostituting. Vivian is industrious at times, is ignorant and poor, but mentally alert enough to select as her paramours those who are able to provide for her. A short time ago she was arrested for disorderly conduct and sent to jail and the daughter at the same time was sent to a Children's Home. Jerry's children are as follows: VI 652 , formerly a prostitute but now married, with two children; VI 653 , also a prostitute, now married; VI 655, a girl who died in infancy; VI 656, a prostitute, handsome, neat in appearance, a waitress in a hotel; VI 657 , a boy aged 16 , average in school work, but lazy and inefficient, now working as a farm-liand at the same place as his father; a girl, VI 658 , aged 14, of average school ability, a pretty, attractive child, who is now with her mother and being morally depraved by her; and last of all a girl who died in infancy.

Harmon, V 272, brother of Jerry and the last member of this group, was born in 1873 . He was mentally below par, ignorant, but a good worker. At 18, led on by his older brother Willett, he committed the crime recorded previously. He was sent to State prison for 8 years. When he left prison he was a sufferer from tuberculosis. He became a laborer, married Muriel, V 273, had seven children by her, and died at the age of 33 of pulmonary tuberculosis.

Muricl was very ignorant and also syphilitic. After Harmon's death she received town aid for a period of four years and also ran a brothel with herself and two young girls as inmates. She was arrested for rumning a disorderly house, but was discharged on condition that she "leave town." This she accomplished by moving to the next town, $1 \frac{1}{2}$ miles distant - an unsuccessful attempt of officials to solve the sex problem and the problem of the spread of syphilis. Here she lived for a period of several years and died only a short time ago at the age of 40 .

Harmon had seven ehildren: a girl, VI 660, now 14, doing fair work in grade 4, attractive and essentially neat, although poorly clothed, now moral; a boy, VI 661 , in grade 3 at 13 , and trying hard to get along in his studies; and five children who died in infancy of syphilis. 
Bell's sixth and sccond legitimate child was Beatrice, III 18, of "good repute, temperate, and healthy." She never received any outdoor relief, had no property, and was not criminal. She married a cousin, Alexancler, III 1, the illegitimate son of Ada Juke, and these are the ancestors of the distinctly criminal branch of the Juke family. Their descenclants are described under Ada (page 3).

Bell's seventh child was Basil, III 19, "farm kaborer; somewhat industrious; no property; dead." He married his cousin, Claire, III 28, a daughter of Clara Juke. Claire was barren.

Bell's eighth and last child was Beta, III 20. He was a "farm laborer; somewhat industrious; no property; blind with cataract; temperate; at 55, outdoor relicf, 23 years; 78, town burial." He married Kate, III 21, a somewhat industrious woman of good repute. Kate was a sister of Gideon, IV 58, who married into Bell blood, and was an aunt of Lu Ethel, V 50, who married into Ada blood. She survived her husband for a few years, receiving poor relief for a period of almost 30 years. Beta and Kate had two children, both boys.

The first, Jack, IV 80, "laborer; 1845, burglary, 3d, State prison, 2 years, learned shoemaking; 1860, breach of peace, county jail; 1863 , soldier; died at war; no property," He married Gladys, IV 81, and had two girls, Birdie and Becky Ann.

Birclie, V 274, was a "harlot before marriage; not industrious; no property; out door relief ; can neither read nor write; constitutional syphilis; died of syphilitic disease."

Becky Ann, V 276, had constitutional syphilis and died of syphilis while young, This family is now extinct.

The second son of Kíate and Beta was Harold, IV 82, a laborer, who cohabited with a syphilitic woman. This mating was barren.

\section{DESCENDANTS OF CLARA JUKE.}

\section{(Chart 4.)}

Clara, II 5, the third of the five original Jukes, was born in 1776 . She was temperate and reputerl chaste. She married Lawrence, II 6, who could real and write, was licentious, and had shot a man. Clara died in 1830 and Lawrence in 1832. This mion produced nine children: three boys and six girls, Carl, Case, Christina, Charles, Claire, Cora, Carvilla, Clarinda and Clarissa.'

Cart, III 22, married his cousin, Dorcas, III 36, of Delia blood; their descendants are described uncler Delia. Case, III 23, never married.

Christina, III 24, was a pauper and married Nixon, III 25. They had five children, who will be described later.

'The charts of ('lara's and Delia's descendants are so much smaller than those of $A$ da's and Effie's that the reader naturally thinks that Clara and Delia had fewer offspring than the other sisters. But this inference can not properly be drawn; for example, Carl, III 22, on the Clara chart married Dorcas of Delia chart and their numerous offspring are found on chart 5. Cora of Clara chart married Abe of chart 2, and her offspring form a half of chart 2. Thus it is seen that in general the size of the charts has nothing to do with the real number of the descenclants. Certain practical considerations have led me to put branches that are derived equally from each of 2 of the 5 original sisters preferably in charts $1,2,3$, and 6 .
Charles, III 26, cohabited with a harlot for many years, but the mating was barren.

Claire, III 28, married her cousin, Basil, III 19, of Bell blood, and this mating was barren also. Some years ago this couple left the country and hisappeared.

Cora, III 29, a woman of good repute, married her cousin, Abe, III 2, a legitimate descendant of Ada Juke, and is thus (with Abe) the common ancestor of part of the legitimate posterity of Ada.

Carvilla, III 30, married her cousin Bruno, of Bell blood. Their descendants form a large part of the group given as descendants of Bell on chart 3.

Clarinda, III 31, cohabited with Hank, III 32, and has a number of descendants who will be described later.

The last ehild of Clara was Clarissa, III 34. She had an illegitimate child, IV 108, and then had three by another man.

Christina, the first of Clara's descendants who had any children plotted on chart 4, was considered reputable. Her husband, Nixon, III 25, was "smart enough," but could neither read nor write. He was industrious, but never acquired any property, and the couple received help from the town. They had five children: Clarence, Cleo, Cyril, Clement, and Corinne.

Clarence, IV 84, was quite bright as a boy, but went away and has never been heard of since.

Cleo, IV 86, was a harlot, ran a brothel, and has received pauper relief. First she married Ira, IV 85, by whom she had three children. After he died she married Leeman, IV 87, and had three children by him, the last two of whom died young. She received a soldier's widow's pension in her later years, as Leeman was killed in the war. Nothing is known of her two consorts.

Cleo's first child, Syrenius, V 278, was a "dead beat" and secured much help from the town. He is known to have married and to have had five children, but these I could not find.

The second child of Cleo, a girl, died at the age of 4 .

Felix, V 281, the third child, was a laborer and wanclered here and there. He married Ida, V 280, a member of the same degenerate family as Lisle, V 195. They had two children: one boy, VI 664, who has disappeared, and a girl, VI 665, of fair repute and industrious, who married a saloon-keeper and has one very anemic and nervous, but well-behaved, daughter now 9 years of age.

The only child of Cleo's second mating that lived was Carrie, V 283. This woman, born in 1860 , has been a harlot all her life, cohabiting with different men. She is ignorant but industrious, and has no children.

Cyril, IV 89, the third child of Christina, is reported by Dugdale to have had constitutional syphilis. He also acquired syphilis, which he transmitted to all of his children. He was a fair worker, but ignorant; received help from the town and, when he died at the age of 42 , was buried by the town.

Cyril's first wife, IV 88, Theresa, died soon after marriage, leaving one child, Justin, a boy, V 287, who was killed in the Civil War. 


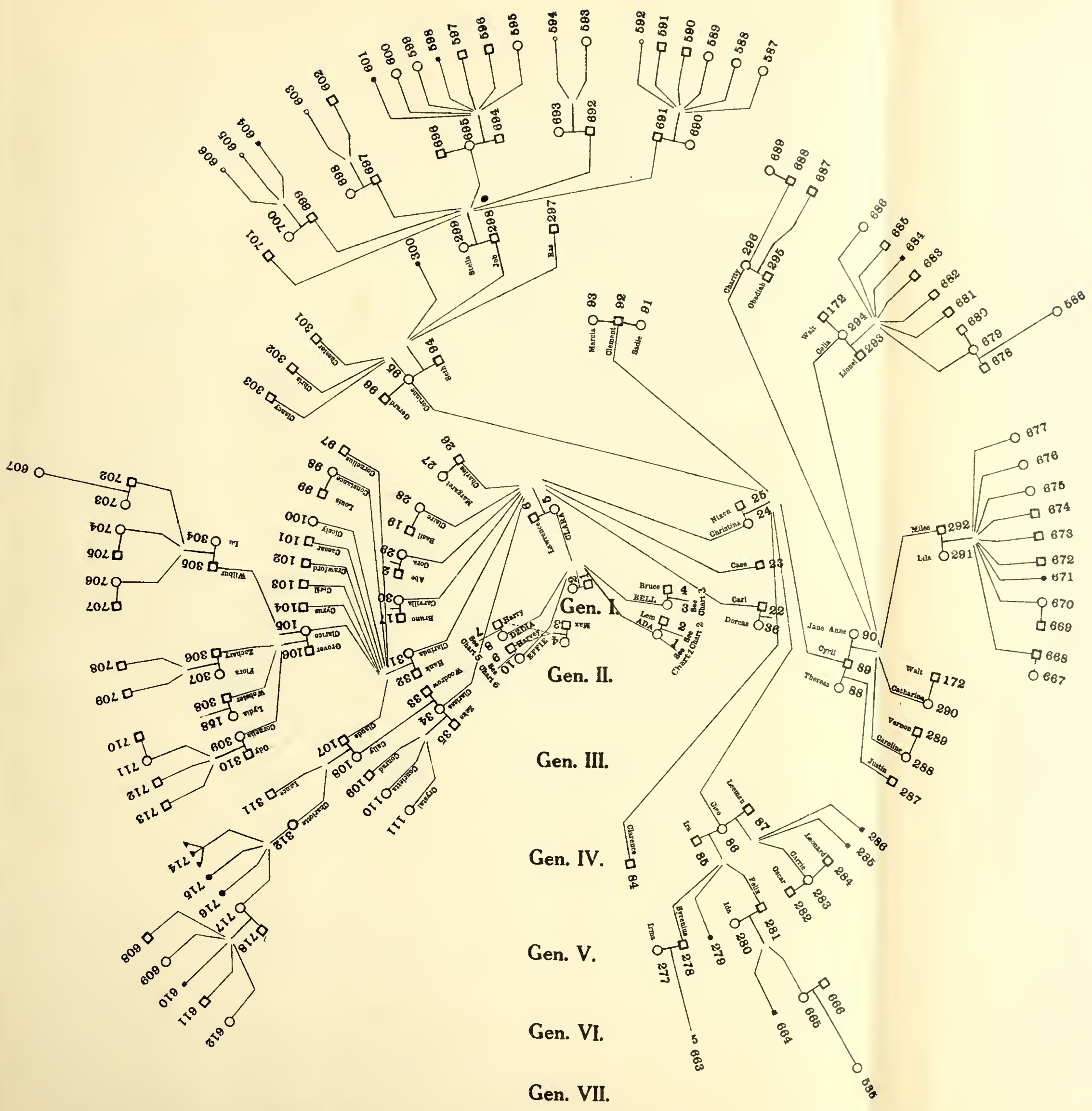

Chart 4. Genealogical Tree of the Descendants of Clara Juke, as recorded in 1915.

Large squares indicate inales over age of five; large circles indicate females over age of five; small
squares indicate males under age of five; small circles indicate females under age of five.
Solid squares and circles indicate dead before age of five.
Solid triangles indicate those dying in infancy sex unknown, and miscarriages.
Name over symbol is a fictitious appellation used in body of description. 


$$
\text { - }
$$


Cyril's second wife was Jane Anne, IV 90, who was "not bright," but very ignorant, and who had a quict clisposition. She was considered chaste. Her children were Caroline, Catharine, Miles, Ceha, and Charity. After Cyril clied Jane Anne with all hel ehildren except Celia, who was then working in a private family, moved from the Juke vicinity to a small manufacturing city in Connecticut. She died when 60 year's of age, 25 years after her husband.

Caroline, V 288, the oldest child of Jane Anne, had fair mentality, but was ignorant and unlettered. She was considered chaste. At 17 she married Vernon, V 289, but has no children.

The second child of Cyril, Catharine, V 290, harl a specch defect and was not considered very intelligent, but she had a pleasing appearance. She married her cousin Walt, $\mathrm{V} 172$, and died some years ago, leaving no offspring.

Miles, V 292, brother of Catharine and Caroline, is an intemperate man. He works well at times, then takes to drinking and does nothing until his money gives out. Then the cycle is repeated. He has been arrested many times for drunkenness, but has never been sentenced. He is a hatter by trade and ean earn good wages. He married Lila, V 291, an ignorant, slovenly, and shrewish womm, a degenerate member of a good family. She died 5 years ago, after bearing nine children.

The oldest, VI 668, a boy, was incapable of dloing a verage school work because his causation was deficient. He works at unskilled labor in a cigar factory and recently married.

The second, VI 670 , left school at 15 , being at that time in grade 6 . She was mentally deficient and had a quarrelsome disposition. A harlot, she married a man who was later sent to State prison for robbery, wherempon she deserted him and is now reputed to be in a brothel.

The third child of Miles died in infancy.

The fourth, VI 672, now aged 21, was incapable of grasping school work, is mentally deficient, has a quiet nature, and is employed in a cigar factory.

The fifth, VI 673, is a quick, active, energetic, talkative fellow. He was keener in school than even the average child, quite a surprise to his teachers who had known his older brothers and sisters. Although he has a menial position in a cigar factory (rolling cigars), yet by his activity he makes good wages.

The sixth, VI 674 , although a well-behaved child, did very poor work in school. He is now a cigarette fiend and lazy.

The seventh, VI 675, now 15, has a poor powel of retention and her causation is deficient. She has a pleasant, open face. Since the death of her mother, her father has forcel her to incest. The eighth child, VI 676 , seems to be mentally capable of doing sehool work, but will not apply herself. She is lazy, untruthful, and has been a petty thief. She is quite musical. Her father has committed incest with her.

The last child in this group, VI 677 , now 10 , is underfed, anemic, and is unable to grasp school work.

Celia, the fifth child of Cyril and Jane Anne, V 294, was brought up in a very respectable family in the Juke region, and now, as a woman of 50 , is quiet in her actions, soft-voiced, and quite refined in appearance. She nevel harl any schooling, but is ncat, industrious, and tries hard to get along. She married Lionel, V 293, a mentally defective laborer. He was ignorant, but a steady worker.
The wages he received were quite small and so the family was poor. He became very intemperate in his later years and died in 1912. ('olia has always takon in washings. Recently she married Walt, V 172, whose first wife was her sistel ("atharine, but he is not living with leer now, as he sitys lee "ean find no work in $\%$. ." He has returued to Connecticut, where he has always been employed. Celia and Lionel had seven children.

The o'dest, a girl, VI 679, was slightly below average in school work, as her reasoning ability was not developed. She was ahways a good, moral girl, guiet in disposition and fairly industrious. She married when young. Her husband, who was very intemperate, was robbed and killed in a saloon (he had received his wages that day). It is supposed that Obadiah, V 295, committed this crime. V'I 679 had one child by this man, well-behaved in school but very slow. After the murder of her husband she married again, this time a man much older than herself.

The next four children of Celia were boys, incapable in school, but all industrious, not one being vicious.

One son of Celia died in infancy.

The last child, VI 686, is a timid, shy ginl who tries harel in sehool, but can not get along well in her work.

Charity, V 296, the last child of C'yril, is an ignorant, vicious harlot. She married Obadiah, V 295, an intemperate criminal. Obarliah is reputed to have shot a man in Connecticut, and for this reason Charity and Obadiah have returned to the Juke country, which she left as a young girl. Charity had one legitimate chilkl, VI 687, who had a poor menory and was "very stupid" in school. He had internal strabismus. He died of pneumonia at the age of 19. Charity had one illegitimate child, VI 688, who, though backward in school, is a steady worker later in life. He is an amateur magician and has given some very acceptable entertaimments. At 20 he was foreed to marry a girl to legitimize their rhilk. Some few years ago Obarkiah deserted Charity and she has been a harlot and professional beggar since that time.

Cyril's brother", Clenent, IV 92, was a "fine man to work." He was igmorant and reticent; was syphilitic and very intemperate; was a veteran of the Civil War and received a pension. He married sarlic, IV 91, "after dark, and while he was drunk," but later he left her. At 72 he married Marcia, IV 93, who was the widow of $V 416$, and after his death, which oecurred the following year, Marcia received a pension. He had no known descendants.

Corimne, IV 95, sister of Clement, and the last child of Christina, married at the age of 14 . She and her husband, Seth, IV 94, had three children: Ras, Job, and one who died in infaney. Seth was killed in the Civil War, but before he died Corinne becane a harlot, acquired syphilis, and received help from the town. She has three bastard sons: Chester, Chris, and Claney, the first born in the poorhouse. Of these three bastards there is no further trace.

Ras, V 297, the first legitimate child of Corinne, died when a young boy.

Job, V 298, boin 1850, was a farmer and owned his own land. He was not successful at farming and was always poor. He married his first cousin in the out blood, Stella, V 299. She was then 18 years of age. This 
mating produced six children. Stella left her husband about 15 years ago and came to the city of $Z$, where she remained. She is ignorant, has a cross disposition, is reticent, and sullen at times. Since she separated from her husband she has been a harlot. She has worked hard and earned good wages, but owing to poor management of her household affairs she has been compelled to ask for town help for some time.

The first child of Job and Stella was VI 691. He is a farmer and has done fairly well on the place which he inherited from his father. He is married and has six children, three of whom, now attending school, are below the average of others of the same age.

The second, a boy, VI 692, is a mechanic by trade and has moved away from the Juke region and is now doing well. He is married and has two young children.

The third, VI 695 , is a woman of neat appearance with noticeably beautiful teeth, who married very young and had seven children, two of whom are now dead. The others are in school and are progressing well. After the death of her first husband VI 695 married again, this time a worthless individual. Simultaneously with this marriage she began to receive town help, and, a short time ago, while several of her children were sick with typhoid fever, she received a great deal of private aid also.

The fourth child of Job, VI 697 , is a steady-going fellow who has gone to work in the wood-yard business and has done well. He is married and has two small children.

The fifth child, VI 699, is more "rattle-brained" than the others and has tried his hand at several things, but seems to be successful at none. He too is married and has two young children living and one child dead.

'The last of this family, VI 701, is much like his next older' brother, but very glib of tongue and given to bluff. $\mathrm{Hc}$ works at odd jobs and sometimes peddles papers

Clarinda, III 31, the daughter of Clara, was never married, but lived for many year's with Hank, III 32. Of these two nothing more is known. They had nine children, only two of whom, Clarice, IV 105, and Claude, IV 107, could be traced by me.

Clarice had one bastard, Wilbur, V 305, before marriage. This man, rough, uncouth, and of a criminal nature, had three children, one boy and two girls, who are reported to be socially adequate. Clarice is supposed later to have married Grover, IV 106, an unlettered, poor farmer, and had three children: Zachary, Webster', and Cornelia.

Zachary, V 306, spent the last seventeen years of his life in the poorhouse and left two sons, both steady workers, although not particularly intelligent.

Webster, V 308, blind in later year's, married a cousin, Lydia, V 158, of Adla blood, and their descendants are described under Ada (page 22).

Cornelia, V 309, married, had three children, and has nloved away from the Juke vicinity.

Claude, IV 107, a farmel who owned his own farm, married his first cousin, Cally, IV 108, the bastard daughter of Clarissa, and had two children: Iance and Charlotte.

I ance, V 311, is a simple-minded, talkative, complacent individual who has never attended school. He inherited a large farm from his father, most of which, through neglect, goes to waste. He never married.
His sister Charlotte, V 312, had six illegitimate children, five of whom died at birth or soon after. The sixth, a girl, VI 717, is still living. At one time Charlotte cohabited with Zachary, her cousin, but it is said none of her children are by him, as she was very promiscuous in her sex relations. She, also, inherited land from her father. She is now dead.

VI 717 , now 45, when young, marricd an industrious farmer who had property worth $\$ 800$. He died prematurely of tuberculosis. His wife sold the farm, moved with her four young children to a nearby town, and recklessly spent the money. Her home soon became poverty-stricken. She appealed to the poormaster for help, although he had previously advised her not to sell the farm. The social worker was called in to handle the case.

VII 608 , the oldest child of VI 717, was sent to a hospital for tuberculosis, and is now practically a well boy.

The second child, VII 609 , an epileptic, was sent to the State Epileptic Home.

The third child, VII 611, a boy, was placed in a Children's Home and has recently been sent to a good home in the Middle West.

The fourth, VII 612 , a little girl, was sent to the Children's Home. Her behavior was apathetic and she took little interest in her surroundings. An examination of her at the Neurological Clinic showed a neuropathic make-up. She reacted negatively to the Wasserman test for syphilis. She improved but little in the Home and was returned to the mother. In the meantime the mother had been in the poorhouse for a short period and then went to live with her uncle Lance at his farm.

\section{DESCENDANTS OF DELIA JUKE.}

\section{(Chart 5.)}

Delia and Effie Juke married two brothers, Harry, II 7 , and Harvey, II 9, respectively. Harry and Harvey were the two sons of Max, a descendant of the early Dutch settlers of $Z$ county. Max is described by Dugdale as "'a hunter and fisher, a hard drinker, jolly and companionable, averse to steady toil,' working hard by spurts and idling by turns, becoming blind in his old age, and entailing his blindness upon his children and grandchildren." Harvey married Effie and their descendants are described under Effie. Harry, of whom we have no data, married Delia, II 8. Delia had two bastard sons, III 46 and III 45 , who appeared to have had no children. Delia's legitimate children were as follows:

(1) Dorcas, III 36, a "peddler, prostitute, blind, with two bastards after marriage."

(2) Daphne, III 38, industrious, tempcrate, of good repute, healthy, who married her cousin Aaron, III 3, and who died of old age.

(3) Daisy, III 39, who married Saul, III 40, had help from the town.

(4) Dan, III 41, "millwright, outdoor relief, intemperate," who married a harlot, Linda, III 42, and had three children, one of whom, IV 135, Dcnnis, was adopted, the trace of all three being lost.

(5) Delta, III 44, who had ten legitimate children and one bastard child. I shall now describe the descendants of each one of these in turn.

Dorcas, III 36, a peddler and prostitute, married Carl, III 22, a son of Clara, and had four legitimate children: 
(1) Desdemona, IV 112, an ignorant harlot and pauper, whose offspring will be described later.

(2) Duncan, IV 115, who married, but whose six cliildren, V 336 to V 342 , could not be found.

(3) Dolly, IV 116, an ignorant and poor harlot, mother of one bastard child, Millicent, V 343, who in turn was a poor, very ignorant harlot, and died of an overdose of opium, a drug to which she was addicted. Dolly married Sewell, IV 117, an ignorant, semi-industrious alcoholic, and had one legitimate son, Nat, V 345 . Nat, at 14, was sent to the House of Refuge for two years on a charge of vagrancy. He grew up to be an ignorant, inefficient alcoholic - a typical Juke. He has been twice "married."

(4) Diana, IV 118, was the last legitimate child of Dorcas. She was a harlot who went to the poorhouse at 22 ; all trace of her since then is lost.

After the death of Carl, Dorcas cohabited with Sam, III 37, "a peddler, decent at first, but whose continued intemperance brought him down mentally and morally." Dorcas had two bastard girls by Sam, Dora, IV 120, a harlot and a recipient of outdoor relief, and Dorothy, IV 121, who disappeared.

Desdemona, the first child of Dorcas, was a harlot before marriage, ignorant, yet considered mentally rather keen and wide-awake. She married Ralph, IV 113, and had fifteen children by him, five of whom died in infancy; her family received much help from the town. Desdemona ran a brothel with her daughters as inmates. Her husband, born 1786, was licentious and a beggar. He was convicted of grand larceny and sent away at one time. He is spoken of by people who knew him as "smart enough." He was industrious at times and just before his death acquired 3 acres of land. The children of Desdemona and Ralph were:

(1) Florence, V 314, an ignorant, syphilitic harlot, who had two bastards after marriage, and one child born in the poorhouse.

(2) Frederick, V 317, ignorant, licentious, semi-industrious, a wanderer; at 32, in the poorhouse with his whole family.

(3) Harriet, V 319, a harlot.

(4) Octavia, V 322, who could read and write a little, a harlot before marriage and poor.

(5) Ion, V 325, ignorant, a harlot, and mother of a bastard child after marriage.

(6) Ida Belle, V 326, adopted when young into a well-todo family, now a spinster of 70 with much property, neat and intelligent in appearance, but a careful study of whom revealed the fact that the refinement was superficial.

(7) Josie, V 329, uneducated, with no sense of right, and a harlot af ter marriage.

(8) Luella, V 331, a prostitute with a bastard child; ignorant, a recipient of poor relief.

(9) Leah Maria, V 333, an ignorant harlot who divorced her husband to live with another man.

(10) Libby, V 335, who cohabited with a cousin, Mick, $\mathrm{V} 202$, and died in childbirth.

The first of these, Florence, V 314, who had acquired syphilis, married Frank, V 313, a fairly industrious fellow who enlisted in the Civil War, where he was killed. Florence had three legitimate children by Frank.

The first, VI 720 , at the age of 18 , was in the poorhouse with her mother. She had constitutional syphilis and has also acquired syphilis. She is ignorant, lazy, and a wanderer. She married an intemperate, lazy, loquacious man, of defective make-up, who inherited property. He and his wife lived in a lovel on his property and had nine children, five of whom died at birth and one, VII 618, at the age of 18 .

The oldest of VI 720's children, VII 614, consorted at the age of 14 with a man then 64 years old, VII 613 . He was a grandfather by a previous mating. After this couple had two stillborn ehildren, they married and then had two legitimate children, both boys, one now 11 years of age, VIII 129, who goes 5 miles every day to school and is trying hard to learn something, and the other now 8 years of age. The father and mother of these two lived in a $\log$ hut owned by VII 15, who had married into the Juke family elsewhere. While the husband lived the family fared poorly on what he earned, but since his death, 2 years ago, at the age of 76 , the family has been in dire want. The woman has consorted with Italian laborers and others and as the mistress of VII 15 she is allowed to remain in this log liut "rent free." She is very deaf, is now tubercular, and reported syphilitic. She and her two children now live in one room of the two-roomed log cabin. Many of the window panes are gone, the holes are stuffed with old clothes, the one dilapidated stove (used for both cooking and heating) seems to pour more smoke into the room than out of the chimney. It is alnost inconceivable that three people could sleep in the one bed of the room, such is its condition. The food of the family consists mainly of potato soup, cabbage, and a form of unraised bread which does not look palatable. In such conditions as these are being raised, with no social restraint, many of the coming generations of Jukes.

The second child of VI 720 is mentally below par, a harlot, and has recently married a laboring man and has one young child.

The third child, VII 617, an intemperate, semi-industrious farm-hand, who has always lived on the "old place" with his mother, has recently been living with VI 525, a syphilitic harlot, whose story has been told under Ada.

VI 720, after the death of her husband, cohabited for a short time with her cousin Enoch, V 395. Enoch and his two young children, VI 858 and VI 859, after the death of their mother, went to live with VI 720 at her hovel house in the mountains, and here Enoch diecl. Here it was that the two young children were found by the social worker, unkempt, underfed, and almost wild. Here also is where VI 525, a syphilitic harlot, went to cohabit with VII 617, after she had deserted her husband and left her five children to starve. It was in this place that VII 614 began to cohabit at the age of 14 with her 64 -yearold paramour.

The second legitimate child of Florence died in infancy. The third, VI 722, is an intemperate, lazy, licentious woman, who, after having two bastard children, has cohabited with her cousin, VI 4, for many years.

After the death of Frank in the Civil War, Florence colnabited with another man. At one time she was in the poorhouse with her children. She had two bastard children, one of whom, VI 723, had constitutional syphilis and was sent from the poorhouse to a Children's Home, whence all records of her cease. The other bastard of Florence died at birth.

The second child of Desdemona, and sister of Florence, died in infancy.

The third child, Frederick, V 317, was a typical Juke. He was a semi-industrious, ignorant laborer, and almost 
all his life was a recipient of poor relief. He was a soldier in the Civil War and for many years received a pension. His first consort, Felice, V 316, died shortly after they began to cohalit; the second, V 318, was Faustina, sister of Jacob, V 330, and by her he had sever children. When he was 32, Frederick, Faustina, and the children went to the poorhouse for one year. Later Frederick deserted them and cohabited with Evelyn, Y 389, a cousin. By this last mating Frederick had several children described under Evelyn. He returned to his wife, Faustina, after Evelyn died, and lived with her until his death.

Faustima is a mentally defective, ignorant pauper. She has been intemperate, and a great wanderer. She is now in the poorhouse for the eighth time and has spent 15 years there. She has been a harlot at various times. Faustina had seven children, all reputed to be by Frederiek.

'The first, VI 725, was in the poorhouse during the first year of his life. At 19 he was sent to State prison for 3 years and 9 months for burglary. He has had several workhouse sentences for various minor offenses and some years ago was sent to State prison for a life term for murder of a girl.

The second child, VI 727, is an ignorant laborer, who had one son, VII 620 , by a harlot woman with whom he is now living. This child is doing average work in school. The third, VI 728, is an indolent, worthless, mental defective, who deserted his wife and three small children in a western State, and joined a religious body in which he poses as an ardent worker.

The next child of Faustina died in infancy.

The fiftli, VI 731, is an ignorant, semi-industrious laborer who recently married.

The sixth, VI 733, was a harlot before marriage and died soon after.

Faustina's last child, VI 735, was brought up by her mother to consider any place her home. She reached the poorhouse at 16 , where she and her mother remained one year. At 19 she again gravitated to the poorhouse, this time for one month. At 20 she came to the poorhouse and became pregnant by one of the keepers. When the child was born it was secretly removed by the father and there is no official record of its birth. Soon after this she was placed in a House of Shelter for a short period. After a discharge from this institution, she went to live at the home of her uncle, Jacol), V 3330, who had intereourse with her. Jacol, fearing she might become pregnant, had her sent from the Juke region to a house of prostitution near New York, lut, before reaching this place, sle was detained by police officials who suspected her destination and was returned to the almshouse which had been lier former home. At the age of 20 she was sent to a custodial asylum for feeble-minded women, where she now is. She hats a low order of intelligence and her mental condition should have been recognized and custortial eare given her early in life, so that the career above descilibed could not lave taken place. It is estimated that the eost of this one individual to the community law been $\$ 1,600$.

The fourtl child of Desdemona and Ralpl was Harriet, V:319. She had two bastards before marriage. She married Gordenier, V 320, who had property at one time. They hat five legitimate children. When the first of IIarriet's children was 12 year's of age, the family, with the exception of this one, who had been placed out, moved into the southern part of a neighboring State, not very clistant from the Juke region. Here the family did not get along well. Three of the young children, then at home, were placed in an orphan asylum. Soon after this the mother died and then Gordenier left the country and has not been heard of since.

Harriet's first child was a bastard, VI 737. This boy, when young, was placed with a farmer and told to make his way in the world. He can read and write, is a great talker, is rather conceited, and thinks he can do wonderful things were someone to help him start. He is intemperate and a wanderer. He has worked at everything from laborer to horse trader. At 39 he was sent to jail for disorderly conduct and later, in the same year, he was sent to State prison for 3 years and 6 months for grand larceny in the second degree. At 41 he was sent to the county jail for 30 days for violating section 426 of the penal code. He was married to an industrious woman of fair repute who has made him a good wife. She is uneducated, but neat, and has tried to bring up her children well. They had nine children.

The first, VII 624, who was of fair sehool ability, is now a laborer working at odd jobs and is slightly intemperate. He married a good, inclustrious woman and has one small child living.

The second, VII 625, was of fair school ability and good repute. Shemarried young and has two young children.

'The third, VII 627 , is much like ler sister. She is married and has one child.

The next two, VII 629 and VII 630, are neat-appearing, industrious, reputable girls. They work in a cigar factory.

The next died in infancy.

VII 632 , the next, is a large, overgrown boy of 15 , who is very slow in school, several years retarded in grade, and lazy and inattentive.

His brother, VII 633 , now 13 year's of age, is a neatappearing, rather attractive boy, who is cloing average work in school.

The youngest in this family, VII 634 , now 11 , is a neat child of average school ability.

None of these children has slown any vicious or criminal traits as yet.

The second illegitimate child of Harriet, VI 739, went with her mother into the neighboring State above mentioned. Here, as a young girl, she was placed at service and cast on her own resources. She remained at housework until, at 20, she married an indolent, semi-efficient fisherman, by whom she had one child, VII 636 , a prostitute and a wanderer, but recently married. VI 739 had her husband arrested for non-support. While he was in jail and after his release she cohabited with the eonstable who had arrested her husband. This man, VI 740, was a widower with grown-up, reputable children. He lived with this woman in his home in the woods for ten years. They lad two children: a boy, VII 637, now 20 years of age, who works at odd jobs in a shoe factory and whose sole object in life is to have a good time, and a girl, VII 638, now 19 , a neat, quiet-appearing, chaste young woman, who is now working in a factory.

After the death of her constable husband, VI 739, the mother of these two children "married" again, this time an indolent, worthless individual, VI 741, by whom she lial one child, VII 639, a rudle-mannered, talkative, forward, mentally defective girl. The woman then deserted this man, ran a restaurant in a large city for a short period, and then moved to a small town near by, where she is clandestinely consorting with the man who induced her 


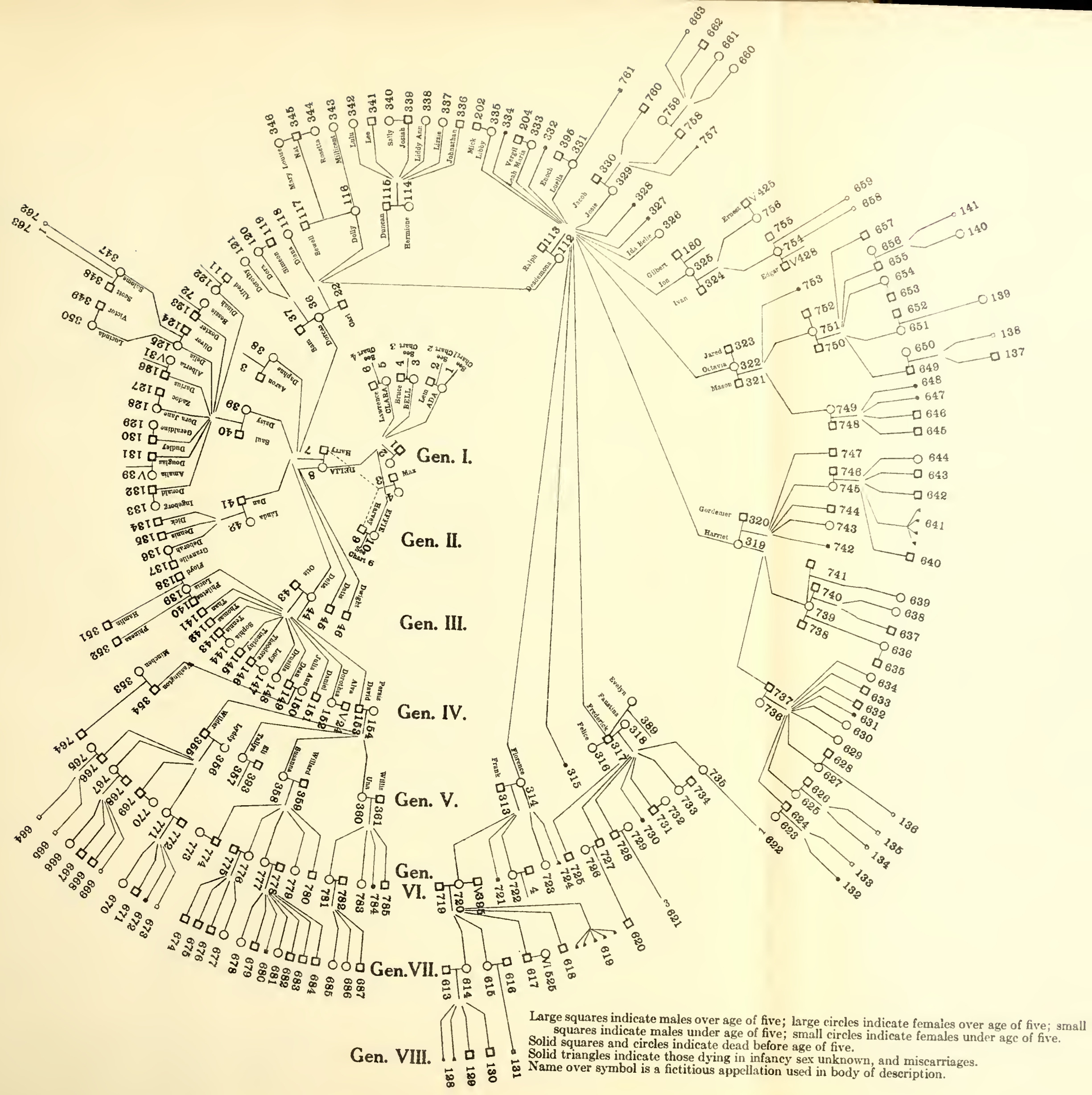

Chart 5. Genealogical Tree of the Descendants of Delia Juke, as recorded in 1915. 

to move to this place. She is unlettered, a great talker, and has a disposition which ean be very disagreeable when aroused.

The first legitimate child of Harrict and Gordenier died in infancy.

The second, VI 743, a girl, was sent, at the age of 10 , to a Children's Home, where she renained a month. The institution record states that she was returned to her mother, but no trace of her could be found.

The next, VI 744, was sent to the Children's Home at the age of 5 , from whence he was adopted, but he ran away from his adopted home, and has not been heard of since.

The fourth, VI 745, born 1871, was placed out at the age of 13 , when her mother died. She has had lit tle sehooling. When very young she married an expert glass-blower who could make good wages at times but was intemperate, probably as a result of his occupation. He deserts his family for long periods of time and his wife has to take on herself the support of the four children. Four others are dead.

The oldest living child, VII 640 , who was slightly retarded in school work, is now working for very small wages.

The second, VII 642, seems to be capable enough mentally, but too lazy to use his brains.

The third, VII 643, is incapable of learning.

The last, VII 644, a girl of 8 , is dull, inattentive, and troublesome in school.

The last child of Harriet, VI 747, was sent to the Children's Home at the age of 4 . He was adopterl, but was returned as unsuitable, and finally died in the Home at the age of 12 .

Octavia, V 322, sister of Harriet and daughter of Desdemona, was born in 1841. She was a harlot before marriage, has never had any education, but can read and write a little. She is a hard worker, but neither neat nor orderly. She has a nervous make-up, is easily confused, and shows memory defect.

Octavia's first husband, Mason, V 321, ignorant, uncouth, and unprincipled, was intemperate, a woodchopper, a teamster, and at times a horse jockey. He acquired syphilis. He died at the age of 60 , and then Octavia "married" Jared, V 323, an inoffensive man, with whom she is now living.

The first-born of Octavia, VI 749, bore a fair reputation, married a man of mediocre ability, and had four children: one who died in infancy of epilepsy; another who died in infancy; a man of 30 who has severe epileptic fits but who has a quiet disposition and no bad habits; and a man of 29 , intemperate, semi-industrious, a typical "sport."

The second child of Octavia, VI 751, was a harlot while young and soon married an intemperate but industrious fellow. After his death a few years ago she married a man much younger than herself. She is fairly intelligent, although she has had little schooling. She has always been very poor.

Her first child, a boy, VII 649 , has a fair education and is a rather steady, industrious fellow. He is untrained, earns but $\$ 9$ a week, is intemperate at times, is married, and has two young children. Two girls follow, VII 651 and VII 654, who married two brothers. These have left the community and could not be traced.

The fourth, VII 655, is a laborer, untrained, and so can make but poor wages.

The last child, VII 657, is also a laborer.
Octavia's sister, Ion, V 325, was ignorant, semi-inclustrious, and a harlot. She married lvan, $V$ 324, a farmer with property, who is stated by Inglale to be "a good ritizen," and had two daughters. After Ivan died, Ion cohabited with her cousin, Gilbert, I 180, by whom she had one bastard, V'I 472, charted under Ciilbert; she died at the age of 59 of eancer of the stomach.

Ion's oldest child, VI 754, horn 1871, cohalited at 16 with her cousin, Edgar, $V 428$, and had soveral bastard children by him. At 19 she married him, legitimizing these children. She had nine childeen by him, three of whom died in infancy. She was a good worker and was considered by some as active and quite acute mentally. At 36 she separated from her husband, while he was in the penitentiary, became a harlot, associated with vicious characters, and spent her fime in low dives. She then cohabited with an ignorant, lazy fellow, and at this time had a bastard son, VII 658, boin in 1908. This child is now with Octavia. About this time Edgar, her husband, was arrested for rape on his daughters, while she was arrested for adultery and sent to the county jail for 25 days. After leaving jail, she cohabited with several men, until finally she took up with VI 755, whom she afterwards married. He is an industrious, rather decent sort of a man and his friends wondered why he ever associated with this harlot. 'This last mating has produced one child. VI 754 has remained faithful to this man for about 5 years.

Her sister, VI 756, married Ermest, V 425, the brother of Edgar. She was ignorant, ahways considered chaste, tried hard to bring up her children well, ensidering her drunken husband, and finally died of tubereulosis and neglect at the age of 34 . Her childen are described under Ernest (see Effie).

Ida Belle, V 326, as has been noted above, was adopted, when young, into a well-to-do family and is now a spinster at 70. She appears intelligent and neat and bears herself with much apparent refinement, but close study indicates that the refinement is merely superficial.

The next two children of Desdemona died in infaney.

Josie, V 329 , sister of Ion, is an uneducated, umprincipled, immoral woman. When young she married Jacob, $\mathrm{V} 330$, a brother of Faustina, V 318 , and of VI 218 , both of whom married into the Juke family. Jaeob committed incest with his niece, VI 735, and he and Josie were the ones who sent her to the house of prostitution as described above. They are now living with their wealthy sistel' Ida Belle. Josie and Jacob have three children.

The first died at birth.

The oklest living child, VI 758, is a lineman for a telephone company and is a steady workman. He is married and has four young children.

The last child of Josie, VI 760, born 23 years after VI 758, is reputed illegitimate, but this fact could not be verified. He is also a lineman, but is not as active mentally or physically as his brother.

The three remaining children of Desilemonil are described above.

The descendants of Daphne, the serond child of Delia, are described under Ada (page 21).

The third child of Delia, Daisy, III 39, married Saul, III 40 , who was the illegitimate son of a harlot by a member of an old Revolutionary family of $Z$ County. This family to the present day is characterized by intemperance 
and licentiousness, even in those socially and mentally prominent. Saul and Daisy received much poor relief from the town. They had eight legitimate children: Dinah, Dexter, Della, Darius, Dola Jane, Duclley, Douglas, anct Donak.

Dinah, IV 122, temperate, ignorant, with the opium habit, married her cousin, Alfred, IV 11, and their children are clescribed under Ada (page 16).

Dexter, IV 123, was a temperate laborer who maried his cousin, Bessie, IV 72, and their descendants are chescribed uncler Bell (page 31 ).

Della, IV 124, was a harłot, and, after having one legitimate child, Salome, V 347, had a bastark child, Lucinda, V 350. Salome had one bastard and one legitimate child. Lucinda, a pauper, was married but barren.

Darius, IV 126, was a mentally defective, licentious criminal. He married his cousin, Alberta, V 31, and their two children are described under Ada.

Dora Jane, IV 128, was married but was barren.

Dudley, IV 130, a laborer and recipient of poor relief, married but had no children.

Doughas, IV 131, an ignorant, licentious, inefficient laborer, married his cousin, Amalia, V 39 . Their children are described under Ada (page 11). Douglas was murdeled by his brother Donald in a drunken brawl.

Donald, IV 132, was an ignorant, syphilitic laborer, who received pauper relief. He married Ingeborg, IV 133, and she was the real cause of the drunken brawl in which Donald killed Douglas.

The children of Dan, III 41, the fourth child of Delia, have been described (page 36 ).

Delta, III 44, the fifth and last legitimate child of Delia, married Otis, III 43, whose last name was the same as Delta's, though no relationship could be traced. After having ten legitimate children by Otis, Delta hack one bastard child, David, IV 153.

Lucia, IV 139, the first child of Delta, was a harlot who ran a brothel and acquired syphilis. She cohabited with Floyd, IV 138, a criminal in New York City, who was a murckerer, and also with Philetus, IV 140, a syphilitic brothel-keeper in the Juke country. She had two bastark children, one by each; both of these children ched of syphilitic chisease while very young.

The next four chilkren of Delta were boys, and of these nothing is known.

Theodore, IV 146, who was the next known child of Delia, was an intemperate pauper. At the age of 67 he was sent to a hospital for the insane suffering with senile (lementia, and here he died several months later. He was married, but hat no chilkren.

Delta's seventh child, Drusilla, IV 148, was a prostitute, blind in one eye, and committer suicide many years ago.
Dean, IV 149, the next child, was a hark-working laborer, who worker for one man for many years. He was intemperate, always poor, and is now in the poorhouse. His wife, Julia Ann, IV 150, was a harlot before marriage.

Dean and Julia Ann had one child, Washington, V 354 , an intemperate loafer who did nothing to support his wife, Minchen, V 353, and their one small child. Minchen was a prostitute and a member of a family noted in the county for its prostitution and pauperism. Some years ago Minchen deserted Washington, and their one child, VI 764, a boy, was sent to the Children's Home and then placed out in the Middle West. A visit to him in his new home showed a boy now 9 , mentally wide awake, quick in actions, and toing well in his school work. He is a wellbehaved boy and is in goot physical condition. He has been with his foster parents two years.

Daniel, IV 151, the next child of Delta, is unknown to me.

Then came Dorothea, IV 152, temperate, a recipient of poor relief, who married her cousin, Alva, V 24, and had many children, described under Ada. Dorothea was the last legitimate child of Delta.

David, IV 153, the bastard child of Delta, was a laborer and a pauper. He married Persis, IV 154, an intemperate woman. Their children were Wilder, Tallya, Susanna, and Una.

Wilder, V 355, is a laborer who is industrious and has acquired property. He never had any schooling, but has done well and bears a good reputation in the community. His wife, Lyddy, V 356, is much like himself. They have four children.

The first, VI 766, is a laborer, who has married and has two young children.

The second, VI 767, is industrious and married to a clunkard. She has a hard time to bring up her four children properly. Two of the latter are average in school, the others being under school age.

The third child of Wilder, VI 769, is a laborer and is married, but the marriage is barren.

The last child of Wilder, VI 771, is lazy, shiftless, and cares little about her house and three young children.

Tallya, V 357, was a woman of gook repute and fair intelligence, who married her cousin, Eli, V 393 . Their children are kescribed under Effie.

Susanna, V 358, was much like her sister Tallya in make-up. She married Willard, V 359, a brother of Lyddy, and had five children.

Susanna's first child, VI 774, is a laborer.

The second, VI 776, a woman of good repute and fair mental ability, married an ignorant laborer. She has two children in school who are below the average in mental capacity.

The third child of Susanna, VI 777, is an uncouth, ignorant, hard-working woman who is married to a backwoodsman and has six children, all below the average in mentality. I tester three of these in school and found them far below age according to the Binet test.

I lave no information in regard to the last two children of Susanna. 
The last child of David was Una, V 360. This woman, full of wit and humor, shows a great deal of refinement and it is hard to believe that she is a Juke. She is neat, industrious, and mentally active. She inarried an intelligent, industrious fruit-grower, Willis, V 361, and they have acquired property. They have three children.

Una's eldest child, VI 781, now 36, was of average school ability. She is a refined woman, now married, and has three young children.

The second, VI 783, a girl, is much like her sister, and lives at home. The youngest, VI 785, is a hard-working boy in high school and has "go and initiative." He is now in the school and is planning to enter college. If he cloes, he will be the second Juke to advance beyond high school.

\section{DESCENDANTS OF EFFIE JUKE.}

\section{(Chart 6.)}

Effie was the last of the five sisters studied. It will be reealled that there was a sixth sister who left the country, but since Dugdale did not discuss her she has been left out of this description. Nothing further is known of Effie than that she married Harvey, II 9, son of Old Max. Harvey and Effie had four children:

(1) Earl, III 48, "a laborer, deserted army 1812, received pension, blind, outdoor relief, intenıerate, died in the poorhouse," married.

(2) Erna, III 49, married but was barren.

(3) Ed, III 51, reputed to have been married.

(4) Eudora, III 52, a basket-maker, a harlot, not inclustrious; received outdoor relief in her old age. She is the founder of the family outlined in Dugdale's chart IV.

Only two of Effie's children had descendants, Earl and Eudora. The descendants of Earl will now be described. Nothing is known of Earl's wife. They had two legitimate ehildren; Elwood, IV 156, and Elmer, IV 157.

Elwood, born in 1793, was a soldier and received a pension. He was the recipient of poor relief and in 1863 entered the poorhouse, where he lied. He was mentally slow, but a good worker and was not dissipated. He married Griselda, IV 155, and had six children: Elijah, Elisha, Ethel, Elizabeth, Emeline, and Eliot.

Elijah, V 363, born in 1818, was licentious and a recipient of town help, but was consiclered more active and intelligent than his father. He "married" several times, but had ehildren by only two of his consorts. By Millie, V 362, he had a girl, VI 787, of fair repute, of little education, but industrious, married twice, the mother of one child; a boy, who died in infancy; and a son, VI 790, a lazy, ignorant, ne'er-do-well, who was fined $\$ 50$ for allowing people in his saloon on Sunday, and is now working as a laborer. By his second consort, Zelma, V 364, Elijah had one boy and one girl; both industrious and reputable. They have left the Juke country.

Elisha, V 365, a semi-industrious, uneducated laborer, married an ignorant harlot, his cousin, Hilda, V 450, of Effie blood. These two received pauper relief for many years. Their son, VI 793, was an ignorant laborer who worked at many things but was successful at none. He married his eousin, VI 157, of Ada blood. Their children are described under Ada.

Ethel, V 366, was a harlot when young. She married her cousin, Orrin, V 255, of Bell blood. Orrin was a skilled mechanie, and bore, for a Juke, a good name. Unfortunately for his posterity, he married his cousin, an igno- rant, semi-industrious, casy-going, and essentially antisocial woman. They had four children, atl boys, one of whom died in infancy. They are semi-industrious, untrainable laborer's, one of whom, VI 798, was sent to the House of Refuge at the age of 14 for petit lareeny. After the death of Orrin, Ethel cohabited with Ross, V 367, who deserted her soon after their son was born. 'This son is a ne'er-do-well.

Elizabeth, V 368, was an intemperate harlot. She was industrious, was married, but had no children, and is now dearl.

Emeline, V 371, was an ignorant pauper. She married Irving, V 370, an ignorant, inefficient kaborer, with a lefective mentality, but a man who tried to do his best. He was a soldier in the Civil War. This pair had one child, VI 803, an intemperate laborer, who has acquired a little property. He married VI 802, a woman of some schooling, fair intelligence, and of good repute, who has made him a gook wife. VI 802 and 803 had eleven children, seven of whom are now living, as follows:

VII 690, an intemperate and loquacious laborer, who works when the mood takes him.

VII 692, a girl, a fair pupil in school, with erotic tendencies at 15, which were later controlled, a member of the church, and now working in a factory.

VII 694, average in school, chaste, a good worker.

VII 695, who became a poor pupil in school, after having an ear abscess which has affected his hearing and caused mental deterioration.

VII 697, a girl who was very capable in school, but of a nervous temperament and with heart disease.

Two children, still young.

After the death of Irving, Emeline cohabited with Roger, V 372, an ignorant, intemperate, though hardworking laborer. Though receiving a soldier's wirlow's pension, help from the town, and what wages Roger brought in, Emeline's family was very poor. Roger and Emeline had four bastard children.

The first, VI 805, died at the age of 18, soon after marrying.

The second, VI 806, an ignorant but industrious laborer on the railroad, is married and has two children, of whom nothing is known.

Of the third child, VI 808, nothing is known.

The fourth, VI 810 , who has tried earnestly to get along, is a hard-working woman with little schooling and training. Her husband, VI 811, was very inteinperate for many years, but has recently stopped drinking. The family is very poor, as the man is untrained and can earn but small wages. They have had eight children, five of whom are living and are still young.

Eliot, V 375 , was the last child of Elwood. He is now a man of 70 . He lives on the property which he inherited from his father and he, himself, has acquired a little land. He never had any schooling and is an unskilled laborer. He had an illegitimate child, VI 813, by Pearl, V 373. This child became a prostitute. Eliot then married Virginia, $\mathrm{V} 374$, and had three children by her.

The first, VI 815, is a steady, industrious man of good principles. He is maried and has one child.

The second, VI 816, was "fair" in her school work and soon after leaving school married her cousin, VII 7, of Ada blood; they had one child, VII 713, a neat, well-behaved girl of average mentality. After the death of VII 7, which occurred at the age of 20 , VI 816 married again, 
this time an ignorant laborer, much older than herself. She has had five childien by him, two of whom are dead, and the others are still young. She is of good repute, has inclustrious tendencies, and a neat home.

The last child of Eliot and Virginia, VI 818, is a man with no principles, an ignorant laborer who married a feeble-minded girl and left her to consort with prostitutes in disorderly houses. He has a sordicl disposition and is very intemperate. He has been arrested for non-support on complaint of his wife, but each time that he has been brought in to the court and sentence is ready to be imposed, the wife relents and asks that he be given another chance. They have no children.

After Virginia's death Eliot married his first cousin, Viola, V 376, a daughter of Elmer. Viola is an easy-going, semi-industrious woman, witl little education, and too lazy to use the brains that she has. She was 21 when she married Eliot and has had nine children by him.

The first, VI 820, a harlot, is now working in a factory.

The second, VI 821, of fair mentality, married when young, and has two small children, one of whom is dead.

The thirel, like the ninth, died in infancy.

The fourth, VI 824, who was very stupid in school, at the age of 16 had an illegitimate ehild, and married at 17 .

The fifth, VI 826, did average work in school and is now a hard-working boy.

The sixth, VI 827, now 16, mentally slow and backward in school, is an erotic, "silly" girl.

The two youngest, boys, are now doing fair work in school.

Elmer, IV 157, brother to Elwood and grandson of Effie, was an ignorant laborer, and a recipient of poor relief. He is reputed to have been licentious. He married Gitty, IV 158, who had previously been married. Their children were Viola, just described, Eph, Ellis, Edith, Eric, and Elenor.

Eph and Ellis left the Juke country as young boys and have never been heard of sinee.

Edith, V 379, was a harlot. She was inefficient and very ignorant. She married an intermittently industrious, intemperate man and has one living child. This girl, VI 832 , ignorant and coarse, has had two bastards, one of which was born in a hospital at public expense and there died; the other is still living. VI 832 has recently married.

Eric, V 381, is a hard-working man who wanclers in search of work. He is married and has one small child.

Elenor, V 383, died at the age of 8 .

Eudora, III 52, was the last child of Effie. She was a basket-maker, a harlot, a recipient of poor relief in her old age, and not industrious. She married Lewis, III 53, a licentious laborer. He was a recipient of poor relief, and, at 79 , went to the poorhouse, where he remained for three years until his death.

Eudora and Iewis had eight legitimate children:

(1) Edmund, IV 160 , a lazy pauper with no property and a criminal.

(2) Edward, IV 161, a pauper.

(3) Elbert, IV 163, a lazy, syphilitic, and intemperate pauper with no property.

(4) Ellen, IV 165, a harlot, who kept a brothel, and a lazy pauper.
(5) Elsie, IV 166, a pauper and a poorhouse inmate who had a bastard son born by the roadside.

(6) Elias, IV 167, a pauper and an habitual drunkard.

(7) Ella, IV 170, an ignorant but industrious woman, who married very young and moved to IVisconsin.

(8) Edia, IV 171, an ignorant, intemperate harlot.

We will discuss the descendants of each of the above in turn.

Edmund is described by Dugdale as follows:

"Brickmaker; at 18, bastard son; 30, outloor relief, 1 year; 32 , outcloor relief, 2 years; 36 , outdoor relief, 2 years; 38 , outdoor relief, 1 year; 41 , assault, intent to kill, State prison, 5 years; 53, assault and battery, forfeits bail, vagrancy, county jail, 10 days; 54, outdoor relief, 3 years; 56 , poorhouse, 1 yeur ; 59 , outdoor relief, 1 year; 62 , outdoor relief, 1 year; lazy; no property; able-bodied; in full health."

Edmund had a bastard son, Evan, V 385, by Gertrude, IV 159, now unknown. Evan contracted syphilis at 13 and at 17 received outdoor relief and was in the county jail for larceny. At 25 he was prosecuted for bastardy and married the woman. He had three children by her, none of whom can now be found. At 32 he began to receive poor relief and this continued for a period of almost 15 years. At 41 he was arrested for petit larceny and sent to jail for 30 days and later, in the same year, was in the county jail 20 days for assault and battery. He was very intemperate, an idle laborer, and spent the last 10 years of his life in the poorhouse.

Edmund's first wife, and second consort, was Anna Maria, IV 39, of Ada blool. She was a quadroon, syphilitic, and while she lived with Edmund was the recipient of poor relief. Elmund and Anna Maria had one son, Edbert, V 386, a licentious man who was killed during the Civil War.

After Anna Maria died Erlmund married another cousin, Blanche, IV 76, of Bell and Clara blood. Blanche had a small, shrunken body, was blind from syphilis, and was, with her husband, the recipient of outdoor relief for 11 years. Edmund and Blanche had five children: Etta, Evelyn, Emerson, Eli, and Enoch.

Etta, V 387, was a harlot before marriage and had one illegitimate child, VI 838, who died during the adolescent period. She married her second cousin, Jonas, V 200, and was the mother of two feeble-minded criminal sons who are described under Ada (page 27). She was ignorant, semi-industrious, always poor, and died at the age of 60 of paralysis which probably resulted from constitutional syphilis.

Evelyn, V 389 , the second child of Blanche, was a harlot and cohabited, when young, with Leon, V 388, an ignorant, mentally defective laborer and a recipient of poor relief, who, at one time, was sent to the county jail for 90 days for petit larceny. Evelyn had three sons by Leon. She deserted Leon to live with Jurlson, V 390, a licentious, drunken laborer. At that time Judson was married to Leah Maria, V 333, who divorced him soon after this new liaison. Evelyn and Judson had two stillborn children and one boy, VI 845. Evelyn deserted Judson to live with Frederick, V 317, a cousin of Delia blood, and this last mating produced two children. She died at the age of 36 of gastric hemorrhage in a hovel in the mountains. She was ignorant, lazy, and uncouth.

The first child of Evelyn and Leon, VI 840, a bastard, is an ignorant, inefficient, semi-industrious, licentious 

man. He has wandered here and there; he married a feeble-minded woman, and has had four feeble-minded children, all of whom were incapable of learning at school. These children, a boy and three girls, are now being brought up in poverty and neglect in a region far away from the Juke land.

The second child of Evelyn and Icon, VI 841, also a bastard, was much like his brother socially and mentally. He lived with Jane, V 205, an ignorant, mentally defective harlot, who, after his death, married into Arla blood. They had two children, both girls: one, VII 729, a causationless harlot, who married a mentally defoctive man and has two mentally defective and pitifully neglected children; the other, VII 730, a waitress, who is ignorant, mentally defective, and hark a bastand child by VI 847, her unche by marriage. The half sils of these last two children are described under Vergil, V 204, and Jane, $\mathrm{V} 205$, in Ada's description (page 27). Jane is still living. After Vergil's leath she cohabited with a mentally defective, ignorant old man. With Jane in two small rooms live her married daughter, VII 729 , the latter's husband and two children, and her own three mentally defective children by Vergil. This family is very poor and depends for sustenance entirely on what the daughter's husband brings in.

The third child of Evelyn, VI 842, is a furniture polisher by occupation when he works, which is not often. He is very intemperate. At 28 he was sent to State prison for 5 years for burglary in the third degree. Soon after release from prison he married a mentally defective woman, VI 843, who is industrious by spells, ignorant, and was formerly a harlot. The family history of VI 843 is interesting. Her father clied in the poorhouse and her mother, now 80, is a pauper. Two brothers are in State prison. A sister, a notorious prostitute, died in the State Reformatory for Women. VI 842 and VI 843 have one son, thin, underfed, and at the age of 12 incapable of keeping up in his school work. VI 842 was arrested for non-support after he deserted his wife to consort with prostitutes and other low, vicious persons.

The next child of Evelyn that grew up is VI 845, a bastard and a half-brother of the three boys just described. He is an intempclate, semi-efficient man, who works here and there and is never long at one place. He married his cousin, VI 925, also of Effie blood, and their children are described under the cousin (see page 47). While his wife was pregnant VI 845 committed incest with his oldest daughter, aged 15 , who was a harlot at that early age. He is now under arrest charged with this crime.

Evelyn, by her consanguineous mating with Frederick, had two children, a boy and a girl.

The boy, VI 846, an ignorant laborer, married his cousin, VII 19 , but after she left him to become a prostitute, he went away, "joined the army," and has not been heard of since.

VI 848 , sister of the aloove, at the age of 3 was taken into a private home when her mother died. She has attended school and has grown up to be a quiet-appearing, rather refined-acting woman. "The "call of the blood" brought hel back to her relatives; she married at the age of 18 , and lived in the Juke comitry. She had seven legitimate children, three of whom died in infancy.

Her husband, VI 847, a fairly industrious man, and very talkative, became cnamoured of his wife's niece, VII 730, and had an illegitimate child by her. He deserted his wife to eohalsit with another, and V1 848 and her children went to a children's IIome for a short while. The mother worked in the institution for a time, but was so inefficient and nureliable that she was finally sent away and she took the children with her.

Since leaving her husband VI 848 has had one child, which must be illogitimate. She has a shallow mind and is easily influenced by others. She now lives in a city 30 miles distant from the Juke region, where her husband lives, and is supporting herself and children by doing housework and "taking in men boarders." For the past few years she has received poor roliof from the city. Her children are lather hright mentally and aro doing average work in the public schools.

Emerson, V 392, the third child of Edmund and Blanthe, was a blick-maker, who cohabited for 5 years with \%elda, r 391, a harlot. During this period Emerson received outcloor relief from the town. At 26 he was arrested for petit larceny, but was not convicted. He was a soldier in the Civil Wal and in hater year's received a pension. He was always pool. He married a first cousin, Elmira, $\checkmark 423$, of Effie blood, an ignorant, hard-working woman, who was formerly a lazy, shiftless harlot. 'This mating produced seven children, who grew up, as described under Elmira (page 47). Emerson is now dead.

Eli, V 393 , the fourth child of Blanche, was born in 1850. His story is given by Dugdale: "at 19, outcloor" relicf, 1 year; 20, county jail, 30 days, 30 days, 10 days; vagrant, county jail; 22 , sick, outdoor relief, 2 years; married cousin." Eli married his cousin, Tallya, I 357 , of Delia blood, an industrious woman of fair intelligence who could read and write. They had four children, two boys and two girls.

The oldest, VI 850, is a rather clever, industrious fellow, and, at times, has done very well. He was arrested for' disorderly conduct and sent to penitentiary for 3 months, but he was led into this trouble by the instigators of the crime, and it is a question whether he should evel have been imprisoned. He is married and has several small children.

The second child of Eli and Tallya, VI 851, is a brickyard laborer, who works steadily throughout the summer season when loricks are being made. He and his wife save nothing during the summer, so that when winter comes and there is no work, the family is dependent on others. He has two young children.

The oldest daughter of Eli, VI 854, is a mental and moral degenerate. She has always been a prostitute and has associated with the lowest kind of negroes and white men, is intemperate, lazy, ignorant, boastful, and vain. She had two bastard children who died in infancy of neglect. She lived for some time with an indolent, intemperate man, who was sent to State prison for arson.

The youngest child of Eli is a girl, VI 855, who is reputed to have been always chaste. She attended school but little, but is mentally and physically active. She married when young, and has three young children.

Since Tallya's death, Eli has colnabited with Talsby, $V$ 394, the wife of a criminal, ly whom he had one child, which died in infancy.

Enoch, V 395 , the last child of Blanche and Edmund, was born in 1851. He was a "laborer; at 18, outdoor relief, 1 year; 20, outloor relief, 2 years; no property; ignorant and boorish; temperate." He married his third cousin, Luella, V 331, of Delia blood, and lived with her 
until her death in 1890. This union was sterile. Enoch had acquired syphilis. He worked only at times.

After Luella's death, Enoch's cousin, VI 897, became pregnant by him and he "married" her. After marriage she was promiscuous in her relations with men and acquired both syphilis and gonorrhea and died of syphilis at the age of 22. She had two children, both reputed to be by Enoch. After the death of VI 897, Enoch, with the two children, went to live with a distant cousin, VI 720, in her hovel home in the mountains. Here Enoch died of epileptic convulsions. Some time after Enoch's death his two children were removed by a social worker from this hovel to the Children's Home, where they were cleaned, taught manners, and sent to school. The two children, a boy of 9 years, VI 858, and a girl of 3, VI 859, responded quickly to the change in their environment. The boy did well in school and acquired good manners. He is syphilitic. He was recently placed with a family which was unaware of his heredity and disease. The girl, now 5, is a brightappearing child and has recently been adopted. It will be interesting to see what becomes of these ehildren in the future.

Edward, IV 161, brother of Edmund, is reported by Dugdale as follows: "At 22, outdoor relief, 1 year; 32, outdoor relief, 1 year; 36 , outdoor relief, 2 years; 40 , outdoor relief, 2 years; 44 , breach of the peace, county jail; 47 , outdoor relief, 2 years; 49 , poorhouse, 1 year." He married Portia, an ignorant, unindustrious woman. Through some freak of fortune the investigator has been unable to find any trace of Edward or any present trace of his six children. In 1866, Edward, his wife, and six children went to the poorhouse for one year.

A careful search through the records failed to disclose what poorhouse this was. The oldest child at this time was a girl of 13 ; the youngest, 4 . The partial subsequent career of only two of these children is known.

Esther, V 399, the third child of Edward, cohabited at 17 with her cousin, Gilbert, V 180. They had one bastard child, who died and was buried by the town. The family received poor relief for 5 years and soon after this Esther died.

Eliza, V 402, the last child of Edward, was adopted from the poorhouse into a good family. She was reported "vicious and unmanagcable." She became pregnant at 17 , and was returned to the poorhouse whence she was adopted. Here her bastard child was born. The records are very incomplete at this point, but apparently the child died soon after birth and the mother was sent to the House of Refuge. She remained there two years, and after discharge was reported as unmanageable. Here she disappears from record and memory.

Elbert, IV 163, a brother of Edward, was an inmate of the poorhouse at 23 . On leaving that place his weakness followed him, for after this he became a recipient of out(loor relief for a period of 19 years. At 48 he was in the county jail for 5 days, probably as a vagrant. He was a basket-maker, but worked only at times, and then merely to secure enough money for drink. He was very poor, could neither read nor write, and acquired syphilis. He died of a "stroke" at the age of 56. Elbert's wife, Janice, IV 164, had more intelligence and activity than himself; many of her children, as will be seen later, inherited the trait of industriousness from her. Janice acquired syphilis from her husband; she died a few years after he did.

Elbert and Janice had six children: Edna, V 404, a pauper, harlot, and syphilitic; Emanuel, V 406, who is industrious, and has tried to do well; Ez, V 407, an unindustrious pauper; Emma, V 408, reputable and industrious, but ignorant; Eunice, V 410, lazy and a harlot; and Ernestine, V 412, scmi-industrious and a harlot.

Edna was intermittently industrious, sluggish, and indifferent; she could read and write, was a harlot before marriage, and had constitutional syphilis. She married Milton, V 403, poor and inefficient, the father of her eighteen children, only three of whom grew up; these were girls. The oldest was a brothel-keeper who was sent to jail and has since disappeared; another is a conceited, high-tempered, rather industrious woman who is married but has no children; the third is unknown.

Emanuel is hard-working, has acquired a little property, and bears a good name in the community. He married Minna, V 405, who was ignorant but reputable, and they had six children, three of whom died young. One, VI 864, is an industrious, rather steady-going fellow of fair mentality; his brother, VI 867, also energetic and of good repute, married his cousin, VI 513, but later divorced her on account of her immoral actions. The last, VI 868, is an industrious and rather easy-going fellow who is married and had four children. The only surviving child, now 9, is shy, quiet, and learns with difficulty.

Ez was industrious at one time and acquired a house and a half acre of land, but after this spurt of industry has done little work. He has constitutional syphilis and is now troubled with "heart disease which prevents him from working." He is a great talker and is willing to entertain one for many hours with stories of his earty life. $\mathrm{He}$ married a cousin, Matilda, V 157, a descendant of Ada, and the two have received much poor relief. The children of this couple are described under Ada (page 22).

Emma was born in 1858. When very young she married Merllie, V 409, a Civil War veteran much older than herself. She has always borne a good reputation, has worked hard, and tried to bring up her family well, has never attended school, but can now read and write. She is kind-hearted, has a pleasant disposition, and is generous and unsclfish. Merllie is semi-industrious and receives a soldier's pension which is sufficiently large to keep the family from want, which may contribute to his little desire to work. He is now the caretaker of a large icehouse, a position which gives him a house free of rent and little active labor, He is talkative and has an easy-going disposition.

Emma and Merllie had thirteen children. The first, VI 871 , is reputable and a hard worker, but slovenly and untrained in matters of cleanliness and efficiency. She married a hard-working but ignorant gardener when very young and has had ten children: four boys, mentally incapable of good work in school, although they tried hard; one girl, aged 12, capable in school; one boy who did well in school; three young children; and one dead. These children have all been brought up in poverty and as they reached the age of adolescence went to work.

The second child of Emma died in infancy.

The third, VI 873, married when very young and went to Canada, where she died, leaving five small children, who were placed in a Children's Home in the Dominion. 
The fourth, VI 875, of fair mentality, but not apt in school, was reputable and industrious. She married a cement-worker, who is industrious and rather steadygoing, and has four children: a boy of 13 doing fair work in grade 4; a girl of 10 unable to acquire first-grade work; and two young children.

The fifth child, VI 877, a hard-working, well-intentioned boy, was killed in a mine accident at the age of 24 .

The sixth, VI 878, had a fair reputation, was slow in school, married young, and died at the age of 25 , leaving her three young children. These have been taken by their grandmother, Emma, who is raising them with her own children.

The seventh child of Emma died young.

The eighth, VI 881, did fair work in school, left at 16 , and went to work as a waitress in a hotel. Bad associations soon led her to immorality. She married a steadygoing young farmer, but soon left him, became a waitress again, and is now leading a life of prostitution. She has wandered here and there.

The ninth child died in infancy.

The tenth, VI 884, an attractive, pleasant appearing girl, was "dull" in school and behind grade for her age. After leaving she followed the steps of her older sister, secured a position as a waitress, and is now a prostitute at the age of 19 .

The eleventh child, VI 885, is doing average seventhgrade work at 15 , although he attends school irregularly.

The twelfth child, VI 886 , is much like his brother, although not so capable in school.

The last in this family is still young.

Eunice, V 410, a sister of Emma, was a hartot before marriage, had a defective mentality, is ignorant, suspicious, slipshod and careless about her house and personal appearance. Her husband, Peter, V 411, a semi-industrious boatman, earns poor wages and the family has always been in want, but has never applied for relief from the town. Eunice and Peter have four children, three girls and one boy.

The first, VI 889, was an ignorant, forward, erotic girl, who, at the age of 17 , had an illegitimate son, VII 771 , supposedly by a shiftless man much older than herself. It is reputed that she married this man; at any rate, she lived with him for several years and had two girls. While her children were still very young she became promiscuous in her sexual relations. Finally, at the age of 27 , being jilted by a man with whom she was in love, she committed suicide in a saloon by drinking poison.

Her son, VII 771, now aged 20, is an imbecile of low grade, a bully, and cruel to his two younger sisters. He can not learn to do any skilled work and so is a laborer at most menial tasks. He lives with his aunt, VI 893.

The two claughters of VI 889 are thin, anemic, mentally weak girls who are now with their aunt, VI 890 . It will be interesting to note the future career of these two girls with their low mentality and inherited eroticism.

VI 890, the second child of Eunice, was married, when young, to an unlettcred but industrious mill employee, who receives $\$ 10.50$ per week regularly. He was committed to a hospital for the insane at 35 and again at 36 , suffering with manic-depressive insanity. His wife, who is a hard-working woman, has managed her house so that her family has never been in want except when the husband has been in the hospital. They have five children, the oldest now aged 8.
The third child of Eunice, VI 893, when very young married a rather reputable young fellow and went with him to Alaska, where he was a prospector. They had two children while in Alaska, both girls. It is reported that the husband was murdered for lis gold. The wife and two children then returned to her home near the Juke country, where the two girls, then aged 8 and 5 , respectively, were placed in the Masonic Home for children. 'They were like wild animals when admitted to this institution, and one of them spat in the face of the nurse who received them. After several years of the best of care and schooling, they are both pronounced feeble-minded and in need of custorial oversight for the rest of their lives. Now they are sexually excitable and to allow them the freerlom of society would mean a future career of prostitution and probally the birth of imbecile illegitimate children. VI 893 "married" again after returning to her old home, but leaves her husband for long periods of time and lecomes a professional prostitute. She is a bold, talkative, conceited, slothful creature who has had little education.

The youngest child of Eunice, VI 895, who is a boatman, is industrious in the summer time when he can secure work. He has recently married.

Ernestine, V 412, the last child of Elbert and Eunice, was a harlot before her marriage to Quentin, V 413, a semiindustrious, ignorant, intemperate boatman. She has attended school but little; however, she can read and write. She allows her house to accumulate dirt until it is almost uninhabitable and then on a spurt will clean it. She has had 13 children, only 3 of whom matured. Three sets of twins died in infancy.

Ernestine's eldest child, VI 897, was a harlot who acquired both syphilis and gonorrhea. She had an illegitimate child at 17 by her cousin, Enoch, V 395, whom she later married, and had another child, supposedly by him. She was a harlot after marriage and died of syphilis at the age of 25 .

The other two children of Ernestine are both boys, physically strong and trying to get along well.

Ellen, IV 165, is a sister of Elbert and granddaughter of Effie. She is described by Dugdate as follows: "Harlot during marriage; 1840 , outdoor relief, 1 year; 1842, outdoor relief, 1 year; 1844 , outdoor relief, 1 year; 1846 , outdoor relief, 2 years; 1862 , outdoor relief, 1 year; kept brothel; acquired epilepsy; temperate; lazy." She married her second cousin, Alan, IV 38, and their numerous children are described under Adla (page 24).

Elsie, IV 166, a sister of Ellen, was a harlot before marriage. She had a bastard son, Ephan, V 414, born by the roadside. Some time after this she had a bastard, Everett, V 416. She later married her cousin, Austin, IV 40, a brother of Alan, who married her sister, Ellen. Elsie continued to wander here and there, tramping the roads and begging. She received town relief and was once in the poorhouse, probably to be confined with child. She died in 1886 at the age of 76 . Her 4 legitimate children are described under Ada (page 26 and chart 2).

Ephan, the first bastard of Elsie, was a good worker, but very intemperate and ignorant. He could neither read nor write, but was so cunning that sometimes, at a horse trade, he could make a little money. He was some- 
what of a wanderer, though not so much so as his mother. He cohabited for some years with his cousin, Ann Eliza. $\checkmark 1$, and had several children by her and finally married her in order to transfer his liut and half acre lot to her. The pair celebrated their marriage by getting intoxicated, and the two danced and walked up the tow path, about 10 miles from where they lived, and Ephan shouted to everyone they saw, "I'm married, I'm glad I'm married." Ann Eliza was subsequently sent to the hospital for the insane, after which Ephan took another "wife," Golden, $\checkmark 415$, who was ignorant, inactive, and mentally deficient, and had four feeble-minded childen by her.

The oldest, VI 905, will work steadily at times. He is a wood-chopper and usually lives in a hut in the mountains or woodlands. Most of his ealnings are spent in drink. He is very talkative, a great air-castle builder, and enjoys creating an impression. He married a cousin, VI 351, of Ada blood, and had several children by her, described under Ada (page 20). VI 351 died of syphilis, consumption, and neglect, and there was no one to give the children any care; a social worker attempted to remove them to a Children's Home, but while the details of this were being worked out, the father moved to another town with his children, there to cohabit with a woman who would take care of them. Then, when the social worker attempted to break up this illicit relation, the whole new family disappeared.

The sccond child of Ephan and Golden, VI 907, is a harlot, mentally defective and tongue-tied. She can neither read nor write, is very talkative, and generally pleasant. Hel reasoning faculties have never developed. She has a very disagreable temper at times. She lived for a short while with V1 906, and, after becoming pregnant by him, married him. She tired of this union after a few years, and transferred her affections to his brother, VI 908, who soon took the place of the husband in the household and the latter left. VI 907 had two children by her first husband: a boy of 12, (loing fair work in school, and a girl, "very stupid." The two children by her second "husband" are still young. Her husbands are members of the "F" family, a group of mental and social degenclates living in the same community as the Jukes, which has furnished many consorts for the Jukes. The two brothers who married this woman are both semi-industrious farm laborers.

The third child of Ephan and Golden is a male, VI 909, who is so tongue-tied that one can understand him only with diffeulty. He has attended school several terms, but could not learn to read or write. He does no work lequiring intelligenee, is able to do only the simplest chores about the place, and these under direction. While visiting his older brother, he became infatuated with a married woman, a niece of V 170 , and of VI 216 in the out blood. Of the same mental ealiber as VI 909, she also has a speech defect and talks so thickly that one can scarcely catch her meanmg. VI 909 at 26 persuaded this married woman to l'un away from her hushand, who was giving her a good lome; she left, taking with her the graphophone, a cow, and her three young children, one an idiot. The cow was left at her mother's place, and the man put his new-found family in a one-room hut not far from the five-lake region of the first Jukes. Several weeks of this life passed when the man came home one day and found the idiot child crying. As it did not desist on his command to do so, he abused the child and injured it so severely that it was taken to a hospttal and for a time its life despaired of. He was arrested for assault in the third degree. I tested his mentality while he was in jail, and though physically 26 , he was found to be 9 years old mentally by the Binet test. The officials then decided that a correctional institution would do him no good, so he was discharged with a warning and reprimand. The woman with her childen then returned to her legal husband, who received them kindly.

The youngest child of Ephan and Golden, VI 910, is of the same low mental grade as her brother. She was incapable of grasping school work and soon after leaving school became a harlot. When she was 20 her mother died and the home was broken up.- She cohabited with a married man, but left him to live with her cousin, VI 349 , who had deserted his wife and children. She has recently had an illegitimate child by him.

The mating of Ephan and Golden has produced a group of mental and social degenerates. The sterilization of Golden at puberty would have eliminated, in the first filial gencration, four mental defectives incapable of coping with the world.

Everett, $\mathrm{V} 416$, the second bastard of Elsie, was born in 1834. He was a basket-maker, and, although he had acquired a house and lot, he received town help for many years. He seems to have been a harmless sort of a man with a quict disposition and he never drank. He married Marcia, IV 93, who will be found elsewhere in the Juke story, as she had been the consort of two Jukes (page 35). Everett died in 1889, leaving no issue.

Elias, IV 167, brother of Elsic and grandson of Effie, was an habitual drunkard and was the recipient of poor relief for many years. At 33 he was arrested for assault and battery and forfeited his bail; at 47 he was again arrested, this time for disorderly conduct, and selved 30 days in jail. He was blincl in his old age. He and his family wandered about the country a great deal and never settled long in one place. He married Flossie, IV 168, a deaf and dumb woman, and had eight childlen by her.

The first, Elsa, V 417, died young.

The second, Eva, V 419, was unindustrious and a harlot. She coukl read and write and was temperate, but never acquired any property. She married and had three sons, but the family moved away from the Juke region into Connecticut, and could not be traced.

Evander, V 421, the third child of Elsie, was reported unindustrious at the age of 19 . A little later he was inclustrious and acquired property. He could read and write and was always temperate. His first wife, Lucina, $\checkmark 420$, died soon after marriage. His second wife, Jean, V 422, was industrious and reputable, but brusque and short in her dealings with others. Evander had seven children by Jean.

The first two died in infancy.

The third, VI 916, is a clean-cut, intelligent fellow, who has worked himself into a responsible position on a railroad.

The fourth, VI 917, a girl, was reported an average child in school, is now chaste, and works in a shirt factory.

The next boy in this family, VI 918 , is not as active physically or mentally as the first two, but is well-intentioned and tries to do his best.

The sixth, VI 919, reached high school, but could not carry on the work; has now left, and is employed. 
The last in this group, VI 920, is 110w, at the age of 15 , in grade 7. She is an "average pupil of that grade, but is slow mentally, inclined to be stubborn, and at times sullen."

Elnira, V 423, the fourth child of Elias and Flossic, was a harlot before marriage. She was not industrious when yourg, but later events made her the whole support of her family. She attended school a little and now ean read and write. When young she married her first cousin, Emerson, V 392, of Effie blood, a brickmaker. Emerson had been living with Zelda, who had left him to cohabit with another. Emerson and Elmira were very poor, and, although he earned good wages in summer, when the brickyards were in operation, they thought little of the future, and during each winter the family was in want. At 26 Emerson was arrested for petit larceny but was not sentenced. He was a soldier in the Civil War.

Emerson died and Elmira then married Jerome, V 424, a ne'er-do-well, who has been arrested many times for intoxication. The whole family, including the children by the first mating, then moved to a manufacturing city in Connecticut, where they have remained. The two children by the last mating will be compared with those by the first.

The first child of the consanguineous mating, VI 922, a cross, irritable, shrewish woman, attended school but little and is now inefficient and slovenly. She married VI 921, a son of Joel, V 427, by his first wife. VI 921, with his brother and sister, was arrested, at the age of 12 , for stealing a watch and was sent to the House of Refuge. The boy was not vicious and committed no more erimes after discharge from the institution. He has little learning in spite of his opportunities at the Institution, is a hard worker, but, because of inefficiency and lack of foresight on the part of his wife, the family is poor. VI 921 has two children, both girls.

The older, VII 785, was incapable of average work in school; she is now chaste and employed.

The second, VII 786, is doing average work in grade 3 at the age of 9 . They are neat-appearing children.

The second child of Emerson and Elmira, VI 923, was slow and backward in school, but is now industrious and doing well. He is married, but has no children.

The third, VI 925, born in 1881, has attended school but little and was a harlot at an carly age. She married a cousin, VI 845, a bastard son of Evelyn, also of Effic blood. She is a loud-talking, slovenly, inefficient woman, who has had six children, all of whom are being brought up in neglect and with insufficient nutrition.

The oldest of the six, VII 787, was mischievous and very backward in school. She went to work in a factory on leaving school and soon was a harlot. At 15, while her mother was pregnant, her father committed incest with her. She ran away from home in company with a man to a larger city nearby. There she was arrested and committed to the State School for Girls, where she is at present.

The other five children of VI 925 and VI 845 are boys, and the three old enough to attend school are physically and mentally below normal. Their father, VI 845, is an intemperate man who works by spells at unskilled labor. He is now under arrest for rape on the daughter, as described above.

This family group, as well as the other descendants of Elmira, do not live in the old Juke community, but in a manufacturing section of Connecticut, many miles from their ancestral habitat. In this region their name is not held up as a tern of reproach, and so they are not handicapped by this stigmi. The same social and mental defectives, however, are being produced here as in the Juke region.

The fourth and fifth children of Ehmira died in infancy.

The sixth, a son, VI 928, has harl little schooling, bnt is mentally active and industrious. He is married and las one small child.

The seventh child of Elmira, VI 930, was "arverage" in school, chaste and neat. She is married and has one child.

Elmira's eighth child, VI 932, is a vicious, mentally inactive young fellow, who is now working at odd jobs.

VI 933, the last product of this cousin mating, was below the average in school work, has worked in different factories, but can not kcep a position long.

Elmira had two ehildren by Jerome. The first, VI 934, was underfed, lacked cnergy and concentration in lis school work, but was considered "average mentally." The other, VI 935, is industrious and tried hard, but is incapable of retaining her sehool work.

The last four children of Elmira are now at home with her and are poorly but neatly dressecl. Elmira has been obliged to take in washing for the past twenty years and do housework in order to support her family, as Jerome, her last husband, spends what little he carns in drink.

Ernest, V 425, is the fifth child of Elias and Flossie. He has always lived in the Juke country, is a brickmaker by trade, and follows this oceupation merely for the noney it will insure him for drink. He will work stearlily for a few days, then spend his wages for drink, forgetting entirely that he has a family. In winter, when the brickyards are closed, he remains idle. He married a cousin, VI 756, of Delia blood. She had little schooling, bore a good reputation, and was industrious in spite of the tubereulosis from which she suffered. She was much abused by Ernest while he was in his drunken spells, and died of pulmonary tubereulosis and neglect at the age of 34 .

Four of their five children were boys. These children have always been underfed and abused by their father. They "seem mentally capalle enough to acquire" in school, but have not the physical encrgy to do this. It was also said of them that they never had a chance. The oldest, VI 936, now 23, is casy going, mentally inert, and works in a brickyard. Since the death of the mother the girl, VI 938, has taken care of the house and the children.

Estella, V 426, sister of Ernest, attended school but little. She was a harlot before her marriage. At 20 she married Joel, I 427 , then a widower with grown-up children. Soon after their marriage they moved to a manufacturing eity in Connecticut. Here they have done well and acquired a little property. Joel is ignorant, but industrious and a good citizen. They had cight children. Some were capable in school, three are bchind grade, although trying hard to get along, and all are industrious, each going to work as soon as he leaves school.

Edgar, V 428, the next child of Elias and Flosicie, was born in 1868. He had little schooling, but he picked up the trade of watch-repairing and worked at times at this trade. He cohabited with a cousin, VI 754, of Delia blood, for a short while and then married her. The pair had nine children, three of whom died in infancy. 'The family has wandered about a great deal, never settling long in one place. At the age of 36 Edgar was sent to the peni- 
tentiary for four months for petit larceny. His wife became a prostitute at this time, associating with the lowest characters in $Z$ county; she frequented brothels and low dives and cohabited with a man by whom she had one illegitimate child. She and this man were arrested for adultery and sent to jail. Edgar returned from the penitentiary, went back to his family, and, as his wife had left, secured a "housekeeper," Valeria, V 429. He committed incest frequently with two of his daughters and had sexual intercourse with two young girls staying with his daughters at their home. He was sentenced to State prison for 10 years and died in prison before the expiration of the term. A study of Edgar's children is interesting, as his wife is a sister of VI 756, who maried Edgar's brother Ernest.

Edgar's first child, VI 950, at the age of 13 was a victim of her father's licentiousness and this incest continued for some time. At 22 she married. She is now shiftless and unindustrious; she has no children.

The sceond child of Edgar, VI 951, was a harlot and also committed incest with her father while a young girl. After the father had been arrested on this charge, she attempted to commit suicide by taking poison, then became frightened and ealled for help. Soon after this she was sent to a Church Home because of waywardness. She was discharged from this institution because she was "too bad." She was committed to the State Reformatory for Women, where she remained for a time and was then transferred to a hospital for tuberculosis. Here her actions were so vulgar and her influence so bad that she was sent away. She died at the age of 21 .

The other 4 children of Edgar, who were living at the time of his arrest for lape, were sent to a Children's Home.

The oldest, VI 952, a girl, was 12 in 1908 when the home of her parents was broken up. After being in the institution about 6 months, she was placed into a good religious private home in the Middle West. She attended sehool regularly and, at the age of $15 \frac{1}{2}$ years, was 3 years retalded in her work; she is now, at 18, self-willed and at times stubborn; otherwise she has a pleasant disposition and is well mannered. In her new home she works about the house and does plain sewing. She is now chaste.

VI 954, the oldest son of Edgar, was sent to the Children's Home at the age of 8 . He was placed in a good home in the Middle IVest near his sister. 'This boy has gone to school regularly and, at the age of 14, was doing "fair work" in grade 6 . As he grew older he became more difficult to control. He is an industrious young fellow. He has recently been placed with new foster parents.

The second boy of Edgar, VI 956, was placed in the Home at the age of 7 , and he too went West; he has always been ummanageable and has never (lone well in any of the several homes in which he has been placed. Some time ago he went back East to his married sister, VI 950, but she was unable to control him, and the social worker has been called in to see what she can do.

The youngest in this family, VI 958 , was only 4 when sent to the Children's Home. He too was sent West with his brother's and sister. He has attended school regularly and at 10 is doing very poor work in the third grade in school. He las also been hard to manage and has been ehanged from place to place, but he remains willful, headstrong, and stubborn.

Egbert, V 430, the last child of Elias and Flossie, is a tall, ungainly, very ignorant, feeble-minded man. He has been arrested several times for minor offenses and sent to jail. After becoming familiar with the premises he decided to remain, and now has a "position" as eleanel" in the county jail. He is a harmless man, a steady worker, and does odd jobs about the jail; he eares little for women and has never married.

Ella, IV 170, the seventh child of Eudora and Lewis, was born in 1827 . She married at 17 , Homer, IV 169 , who was then 23. Dugdale, chart IV, generation 4, line 29, states that the pair removed to Prescott, Wisconsin, and had six or seven children, one dead; he dismissed them with this. I find that the pair, after leaving the Juke region, gradually moved West and in a few years had finally settled in Wisconsin, where Homer took up 360 acres of sehool land. He worked this property and, when he beeame old, it was almost free of debt. He suffered from senile dementia at 70 . He was always considered a good citizen and died at the age of 91 . Ella never had any schooling, but always bore a good reputation. She was spoken of as "mentally inactive and easy-going, with little ambition." She died some years ago. Homer and Ella had 10 children.

The first, Eugene, V 431, died at the age of 25. Nothing is known of him.

The second, Elvina, V 432, is spoken of as industrious, fair mentally, but with little edueation and ambition. She married Jasper, V 433, a man of weak mentality, who was industrious and well meaning, but ineffieient and always poor. They had four ehildren, all girls.

The first, VI 960, is industrious, has always been considered a good woman, and has tried to do well. She married a land dealer, a brother of VI 961, who married her sister, and they have moved away into Canada. Their two children are still young.

The second child of Elvina, VI 962, attended sehool for a short period and is considered weak mentally. She married, when young, a farmer, VI 961, who has property. He owns a good farm and is capable, but is so lazy and indifferent that he will not try to support his family, which consists of eight children. The wife, however, has tried hard to do well by her family.

The oldest of these, VII 797, is spoken of by his teacher's as being naturally bright, but listless, lazy, and unable to concentrate his thoughts. He is very erratic in his whole school work and is particularly poor in memory subjects. At 13 he is in grade 7 , but is mable to earry on the work. He seems under-nourished.

The second child, VII 798, is more active mentally than the first, though not as quick as the third. At 11 she is in grade 5 , is neat, and has a pleasant manner.

The third child, VII 799, had infantile paralysis at the age of 2 , is now paralyzed below the hips, and walks on crutches. She is a thin, underfed child, and is now, at 10 , doing well in school in grade 3 . She has a great deal of thought and originality in writing.

The fourth, VII 800, aged 8, is undersized and apparently underfed. He is mentally and physically slow. He does not apply himself in school, can not retain facts, but is a well-behaved, quiet-mamnered child.

The fifth child, aged 7, entered school at the age of $4 \frac{1}{2}$ years, and is now in the third grade. Recently he has seemed listless and does not get along as well as formerly.

The others in this family are still young.

The third child of Elvina and Jasper, VI 963, born 1886 , went out at service when very young. She was seduced 
at 18 and had a bastard son, who is now with his grandmother, Elvina. At 20 she again had an illegitimate child, VII 806. This boy, now 8, is tractable and pleasant, and has been in the first grade for the past two years and does not seem to advance as fast as the average child. The mother recently married. She is easy-going, rather obliging, and has no mental energy. She has a pleasant disposition and is quite talkative. Her husband does little to support her and she still takes in washings, as she did before mariage.

The last child of Elvina, VI 965 , born 1889, was immoral at one time and "easy-going," but since her marriage has been faithful to her husband. She is "smarter" than her sister, just described, but as a child was called weak. She has four young children.

Palmer, V 435, the third child of Ella, was a fat, lazy, ignorant, typical Juke. He had no morals and was always called worthless. His first wife, Floretta, V 434, an aunt of Reese, V 445, was an ignorant but industrious woman, who at first tried to do well by her husband and children. After living with him for many year's and having five children, she left him to live with a paramour and had five children of uncertain paternity: a daughter who is immoral; a son, who was "forced" to marry; a daughter who is feeble-minded, migrainous, has hypererotic outbreaks, and is a menace to the community; and two stillborn children.

After Floretta left Palmer he cohabited with Gussie, V 436, a thoughtless, independent, easy-going spendthrift. She had been "married" before and had one son, VI 967, who married Palmer's oldest daughter. 'These two left Wisconsin some time ago for Oregon.

The second child of Palmer and Floretta, VI 970, is feeble-minded. She cohabited with an old man, a halfbreed; later she left him and has married, or lives with, her cousin of the out blood. 'They have had five children (not shown on the chart). The eldest, a boy of 14 years, is the brightest of the family, but he is dull and does not associate well with his schoolmates. The next child is feeble-minded. The other's are young. ${ }^{1}$

The third child of Palmer and Floretta, VI 972, had little education, but is a reputable woman of quiet disposition, but not bright mentally. She married a feebleminded, industrious, though inefficient man. The family is very poor and has had a hard time to get along. They have three children: a girl, sexually precocious, now moral, doing average work, at the age of 13 in grade 6 at school; and two boys, one lazy, though mentally capable; the other still young.

The fourth child of Palmer and Floretta, VI 974, is now 27, a laborer, and feeble-minded.

The fifth, VI 975, did average work in school as a child, was easy-going, and had a pleasant disposition. She is reputed to have had an illegitimate child before marriage, but this statement could not be verified. She married, at 17 , a steady, industrious man and has four children, all of whom are doing well in the public schools. Palmer and Gussie had two sons: one a laborer, now in Wisconsin, and the other in California.

Eliza Jane, V 437, the fourth child of Ella, was born in Wisconsin. She was of a low mental grade, never had any schooling, but was a hard worker and not vicious. She married Zeziah, V 438, a farmer by occupation, but

${ }^{1}$ Data on VI 970 were furnished by Miss S. C. Devitt. Investigator, Minncsota School for the Feeble Minded, Faribault. a wanderer. For some time after marriage the two wandered over a great part of the Midrlle West, remaining here and there for short periorls. \%eriall was a first cousin of Eliza Jane in the out blood. They had eight children.

The first, VI 982, sedueed a young girl while he was a young fellow; when he discovered her condition he tried to make all reparation in his power, but she berame despondent and drowned herself. He married soon after this and settled in the East on a farm, which he inherited from his grandfather. Iis wife, VI 981, who came from Wisconsin, is a half sister of Reese, V 445. She did not like the East, and was dissatisfied, and so the husband rented his property and went West with her to her people in Wisconsin. He has become a wanderer and does not live with his family regularly. His wife has taken the support of the family on herself and does this by taking in washings. They have six children, all girls, mentally slow and poor in school work. The two oldest are now at housework. They have weak wills and may casily be led to wrongdoing.

The next two children of Eliza Jane died in infancy.

The fourth, VI 984, is now in the East and works steadily in a factory.

The fifth died a young girl.

The sixth, VI 986, is employed at the same place as his brother and is a steady worker, but is unskilled, and receives low wages.

The seventh child died young.

The eighth, VI 988, was delicate as a child. Her father returned to his farm in the East, following her mother's death, and she became a farm laborer and now, at the age of 18 , is a strong, husky girl who ean do the work of a man on the farm. She attended school only a short while, but can read and write. She is considered mentally weak. Her father, /eziah, who inherited property from his father, is an uncouth, talkative, ignorant man with deficient causation. He is now 70 years of age and, since the death of Eliza Jane, has cohabited with a shrewish woman.

Emory, V 439, a brother of Eliza Jane, is a lazy, shiftless ne'er-do-well. He is spoken of as a "bad man" and is a wanderer.

The sixth child of Ella, $\mathrm{V} 441$, died in infancy.

The seventh, Verna, V 443, is a good woman, kindhearted, but mentally deficient. She married Rudolph, V 442, a lazy, inefficient man who has spent most of his time dreaming and building air-castles. He las worked but little and the burden of the family has been on Verna. They have six children.

The first three, who were girls, married, noved away, and nothing is known of them.

The fourth, a boy, VI 995, inclustrious but mentally inactive, has moved away.

The fifth, VI 996, is a boy of weak mentality, who is married and also has moved away from the IVisconsin Juke country.

The last, VI 998, a great cigarette smoker, is weak physically, mentally active, good-hearted, and is now industrious and making a living. He is married and has one young child. Verna died several years ago.

The eighth child of Ella died in infancy.

The ninth, Lillian, V 446, has had some schooling, is industrious, but has no ideals or morals. She married Reese, V 445, a nephew of Floretta and half brother of 
VI 981. There are then three matings between this germplasm and the germ-plasm of Ella shown on chart 6. Reese workerl at ord jobs, was musical, and belonged to a band. He was always poor. Lillian deserted him and he put his children, then at home, in a Children's Institution and cohabited with a woman until his reath a short time afterward. Lillian and Reese harl four children. After Lillian deserted Reese she cohabited with Richard, V 447, a lazy intemperate ne'er-do-well, a fisherman by occupation. They had two children, one of whom died.

The first child of Lillian, VI 1001, attended school and can rearl and write; he is industrious, has saved his money, and now owns a small place; he is married and has three small children.

The second child of Lillian, VI 1002, is an easy-going, shiftless, slovenly girl of 23 , has loose morals, and is not industrious. At 14 she married an intemperate laborer and had two children: a boy, VII 833, a typical street urchin, and a girl, aged 2 years, physically active but who does not yet talk and does not hear.

The third child of Lillian, VI 1004, is a fisherman who works when he pleases. He was in a Children's Home for a short period and has had a little schooling.

The last child of Lillian hy Reese was VI 1005, a talkative fellow who has little breadth of ideas and small education. He is a laborer and works when he can. He has recently marrier.

Lillian's living bastard child by Richard is a girl of 10 , VI 1007, thin, anemic, and with a hysterically nervous make-up. She is now doing fair work in the third grade in school.

Emil, V 448, was the last child of Ella and Homer. He is indolent, weak-willerl, and without morals. He is physically strong and well-built. Before his father died he had stolen money from him and also secured possession, by unfair means, of his father's farm; this was all soon spent foolishly. He married Laura, V 449, of fair intelligence and good repute, who worked hard for her five children, three of whom died in infancy. She died of neglect and overwork at the age of 40 . Emil then put the two children in a Home and since then has wandered here and there. Laura's sister took the children from the institution and has given them a home.

The older, VI 1009, a boy, reached high school, where he did good industrial work, but was very poor in other subjects. He has recently left school and is now on a farm.

The girl, VI 1011, now 11, has attenderl school but one year in her whole life.

This enrls the story of the group of people descended from the mating of Ella and Homer, who left the Juke region and settled in Wisconsin. With the exception of the few mentioned who returnerl East, all of them are in Wisconsin or have moverl farther West.

Edia, IV 171, was the eighth and last child of Lewis and Eurlora. Edia is not mentioned by Dugdale in chart IV of the Juke book. I assume it was an oversight. She was a harlot, ignorant, causationless, intemperate, but indlustrious. She married Kenneth, IV 172, a man much like herself. The family received poor relief for many years. They had five children.

The first, Hilda, V 450, was an ignorant harlot, who married her cousin Elisha, V 365, also of Effie blood. Their descendants are described above.
The second, Ferne, V 451, cohabited for a time with Hendrick, V 71, of " $\mathrm{X}$ " blood found elsewhere on the Ada chart (see page 16). She later had an illegitimate child, VI 1014, who in turn harl an illegitimate child, the latter being born in the poorhouse. Of these nothing further is known.

The third, Mina, V 454, was a harlot before marriage, industrious but very ignorant. She married Marshall, $\mathrm{V} 453$, who was industrious but intemperate. He was sent to jail at one time for petit larceny. Mina had three children.

The first, VI 1015, industrious but intemperate, married his cousin, Samantha, V 152, of Ada blood (page 21).

The second, VI 1016, uneducated but industrious, is considered a good citizen. He is married, but has no children.

The last child of Mina was a girl, VI 1018, industrious and reputable. Her husband clied of tuberculosis, leaving her with two young children whom she conscientiously has supported since then.

Mark, V 455, a brother of Mina, was a ne'er-do-well, lazy, and intemperate. He has been arrested many times for disorderly conduct, assault, and petit larceny.

Morris, V 456, the last child of Edia, died of cerebrospinal meningitis at the age of 23 , about 9 months after his marriage.

\section{POPULATION.}

In this study 2,820 individuals have been considered. Following Dugdale's terminology, the "Jukes" are all of those descended from the common mother, generation I, of the "five original Juke sisters." All others who married into or consorted with the Juke blood are called " $\mathrm{X}$ " bloorl. Table 1 gives the numbers of Jukes and of "X" blood grouped by generations.

TABLE 1.-Population by generations.

\begin{tabular}{|c|c|c|c|}
\hline Generation. & Juke. & "X." & Total. \\
\hline I... & 1 & 1 & 2 \\
\hline II... & 5 & 5 & 10 \\
\hline III. & 35 & 22 & 57 \\
\hline IV.. & 106 & 69 & 175 \\
\hline V. . & 269 & 195 & 464 \\
\hline VI. . & 741 & 330 & 1,071 \\
\hline VII . . & 792 & 96 & 888 \\
\hline VIII.. & 143 & 8 & 151 \\
\hline IX... & 2 & ... & 2 \\
\hline $\begin{array}{l}\text { Total....... } \\
\text { (Dugdale).. }\end{array}$ & $\begin{array}{r}2,094 \\
(540)\end{array}$ & $\begin{array}{l}726 \\
(169)\end{array}$ & $\begin{array}{r}2,820 \\
\quad(709)\end{array}$ \\
\hline
\end{tabular}

Of the 2,094 Jukes enumerated, 378 died under the age of 5 years. There are 1,258 of the described Jukes now living, scattered throughout 20 States of the Union and in Canada. Although many are old, the great majority are now in the prime of life and reproducing continually. The younger generation is still in school. The Jukes of to-day are to be found in all classes of society. The good citizen, prosperous and rearing a family with good moral and mental stamina, has earned his place in the community. Then there is the more numerous class, com- 
posed of steady, hard-working persons who toil from clay to day at semi-skilled or unskilled labor and make no deep impression on the community, but rear their children as well as their limited outlook on the world will allow, endeavoring at least to rear them to the parental social level. Again, there is the scum of society represented among the Jukes. These are inefficient and indolent, unwilling or unable to take advantage of any opportunity which offers itself or is offered to them. These form the real social problem of the Jukes of to-day.

An attempt has been made to classify the living Jukes into these three classes. There are 748 Jukes over the age of 15 considered in this connection. There are, roughly speaking, 76 in the first class, the socially adequate; 255 individuals are doing fairly well; 323 are typical Jukes of the kind described by Dugdale, and 94 were unclassified, due to lack of sufficient information. The writer realizes that these figures mean little except to give a comparative idea of the general proportion of the three classes. As time goes on many of the younger ones classed as "doing poorly" may, through added responsibility and as the result of experience, enter the second or even the first class. Those who remain, not profiting by experience, are the mentally deficient, for whom nothing can be done except to give continual oversight or custodial care.

\section{MARRIAGE RELATIONS.}

The table given below shows little of interest. There were more women of marriageable age than men and relatively more women than men became married. What is the meaning of the seeming larger number of females of marriageable age and their tendency to marry more than the males is not apparent from any data gathered here.

TABLE 2.-Marriage relations in the Jukes.

\begin{tabular}{|c|c|c|c|c|c|c|c|}
\hline & \multirow{2}{*}{$\begin{array}{l}\text { Marriage- } \\
\text { able age, } \\
\text { number. }\end{array}$} & \multicolumn{2}{|c|}{ Married. } & \multicolumn{2}{|c|}{ Unmarried. } & \multicolumn{2}{|c|}{ Unknown. } \\
\hline & & No. & P. ct. & No. & P. ct. & No. & P. ct. \\
\hline Juke males. . . . . & 463 & 269 & 58.1 & 145 & 31.3 & 49 & 10.6 \\
\hline Juke females. & 541 & 372 & 68.7 & 135 & 24.9 & 34 & 6.4 \\
\hline Total... & 1,004 & 641 & 63.8 & 280 & 27.9 & 83 & 8.3 \\
\hline
\end{tabular}

\section{FECUNDITY.}

An analysis of the figures of the Jukes in regard to the birth-rate shows that of a total of 403 married Juke women, 330 reproduced one or more children and 73 were barren. The average fecundity, counting those who are barren, is 3.526 children per female. The 330 women having children have an average fecundity of 4.306 as compared with that of 4.025 , based on 120 reproducing women in the Nam family. On the other hand, 265 of " $\mathrm{X}$ " blood in the Juke study, including 71 barren, had an average fecundity of 2.554. (See table 3.)
TABLE 3.-Fecundity.

\begin{tabular}{|c|c|c|c|c|c|c|c|c|c|c|c|c|c|c|c|c|c|c|}
\hline \multirow{2}{*}{$\begin{array}{c}\text { Genera- } \\
\text { tion. }\end{array}$} & \multicolumn{16}{|c|}{ Number of children of narried females. } & \multirow{2}{*}{ 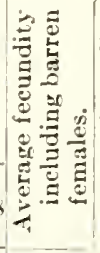 } & \multirow{2}{*}{ 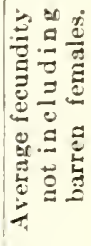 } \\
\hline & $\ddot{g}$ & 1 & & 2 & 3 & 4 & 5 & 6 & 7 & 8 & 9 & 10 & & & 14 & 1518 & & \\
\hline $\begin{array}{l}\text { II : } \\
\text { Juke. } \\
\text { "X". }\end{array}$ & & & & & & 1 & 1 & 1 & & 1 & 1 & & & & & & 6.40 & 6.40 \\
\hline $\begin{array}{l}\text { III: } \\
\text { Juke. } \\
\text { "X". } \\
\text { IV: }\end{array}$ & $\begin{array}{l}3 \\
2\end{array}$ & & & 3 & 1 . & 1 & $\begin{array}{l}1 \\
1\end{array}$ & $\begin{array}{c}2 \\
.\end{array}$ & $\begin{array}{l}1 \\
1\end{array}$ & 4 & 2 & 1 & 1 . & & & & $\begin{array}{l}6.187 \\
2.625\end{array}$ & $\begin{array}{l}7.616 \\
3.500\end{array}$ \\
\hline $\begin{array}{l}\text { Juke. } \\
\text { " X: }\end{array}$ & $\begin{array}{r}5 \\
11\end{array}$ & & 6 & $\begin{array}{l}5 \\
3 .\end{array}$ & 3 & $\begin{array}{l}3 \\
1\end{array}$ & $\begin{array}{l}2 \\
1\end{array}$ & $\begin{array}{l}3 \\
5\end{array}$ & $\begin{array}{l}5 \\
1\end{array}$ & $\begin{array}{l}1 \\
1\end{array}$ & 1 & $\begin{array}{l}2 \\
4\end{array}$ & 1. & & & 1 & $\begin{array}{l}4.472 \\
3.212\end{array}$ & $\begin{array}{l}5.194 \\
4.818\end{array}$ \\
\hline $\begin{array}{l}\text { Juke. } \\
\text { "X". }\end{array}$ & $\begin{array}{l}13 \\
16\end{array}$ & $1:$ & & 111 & 151 & & 7 & 9 & 6 & 4 & 3 & & 4 & 32 & & . 1 & 4.222 & 4.800 \\
\hline $\begin{array}{l}\text { VI: } \\
\text { Jukc. }\end{array}$ & 27 & 2 & & 302 & 552 & 201 & 16 & 4 & 4 & 10 & 6 & 3 & 2. & & & & 3.319 & 3.938 \\
\hline "X". & 32 & 25 & & 171 & 11 & & 7 & & 4 & 1 & 1 & & 1 . & & & & 2.235 & 3.096 \\
\hline $\begin{array}{l}\text { VII: } \\
\text { Juke. } \\
\text { "X". }\end{array}$ & $\begin{array}{r}21 \\
9\end{array}$ & 15 & & $\begin{array}{l}9 \\
8\end{array}$ & $\begin{array}{l}6 \\
1 .\end{array}$ & 6 & $\begin{array}{l}3 \\
2\end{array}$ & & & & & & 1 . & & & & $\begin{array}{l}1.656 \\
1.321\end{array}$ & 2.525 \\
\hline $\begin{array}{l}\text { VIII: } \\
\text { Juke. } \\
\text { "X". }\end{array}$ & $\begin{array}{l}4 \\
1\end{array}$ & 1 & & & & & & & & & & & & & & & $\begin{array}{l}.021 \\
.200 \\
.500\end{array}$ & 1. \\
\hline $\begin{array}{c}\text { Total: } \\
\text { Juke. } \\
\text { "X". }\end{array}$ & $\begin{array}{l}73 \\
71\end{array}$ & $\begin{array}{l}5 ! \\
52\end{array}$ & & $\begin{array}{l}554 \\
452\end{array}$ & $\begin{array}{l}94 \\
41\end{array}$ & $\begin{array}{l}63 \\
81\end{array}$ & $\begin{array}{l}30 \\
15\end{array}$ & $\begin{array}{l}19 \\
13\end{array}$ & $\begin{array}{l}16 \\
11\end{array}$ & $\begin{array}{r}20 \\
3\end{array}$ & $\begin{array}{r}13 \\
4\end{array}$ & $\begin{array}{l}6 \\
5\end{array}$ & $\begin{array}{l}9 \\
2\end{array}$ & 32 & $\begin{array}{l}1 \\
1\end{array}$ & \begin{tabular}{l|l}
1 & 1 \\
1 &.
\end{tabular} & $\begin{array}{l}3.526 \\
2.554\end{array}$ & $\begin{array}{l}4.306 \\
3.489\end{array}$ \\
\hline $\begin{array}{c}\text { Grand } \\
\text { total } .\end{array}$ & 144 & 111 & & 007 & 36 & 44 & 45 & & 27 & 23 & 17 & 11 & & 32 & 2 & $\begin{array}{lll}2 & 1\end{array}$ & 3.140 & 4.004 \\
\hline
\end{tabular}

\section{LEGITIMACY.}

A study of table 4 shows that 79.99 per cent of the total number of Jukes have been born legitimate. At the time Dugdale wrote, 72.63 per cent were legitimate. This would seem to indicate that there was an increase in the chastity of the community, but when it is noticed that 10 per cent of Dugdale's were of unknown status, while only 3.7 per cent of my total are unknown, the difference of 6.4 per cent in the legitimate becomes negligible and no such conclusion is warranted. On the other hand, it is interesting to note that the recorded "percentage of illegitimate" births remains about the same for the two studies. In studying all tables in this paper, it must be remembered that the total figures always include those of Dugdale.

TaBLE 4.-Legilimacy.

\begin{tabular}{|c|c|c|c|c|c|c|c|}
\hline & Total. & $\begin{array}{l}\text { Legiti- } \\
\text { mate. }\end{array}$ & $\begin{array}{l}\text { Ille- } \\
\text { giti- } \\
\text { matc. }\end{array}$ & $\begin{array}{c}\text { Un- } \\
\text { known. }\end{array}$ & $\begin{array}{l}\text { Per- } \\
\text { eentage } \\
\text { of legit- } \\
\text { imate. }\end{array}$ & $\begin{array}{c}\text { Per- } \\
\text { eentagc } \\
\text { of illegit- } \\
\text { imate. }\end{array}$ & $\begin{array}{l}\text { Per- } \\
\text { eentage } \\
\text { of un- } \\
\text { known. }\end{array}$ \\
\hline Juke males.... & 950 & 775 & 163 & 12 & 81.58 & 17.15 & 1.27 \\
\hline Juke females. . & 993 & 836 & 129 & 28 & 84.19 & 12.99 & 2.82 \\
\hline Juke unknown & 151 & 64 & 49 & 38 & 42.38 & 32.45 & 25.17 \\
\hline Total Juke.... & 2,094 & 1,675 & 341 & 78 & 79.99 & 16.28 & 3.73 \\
\hline dale's time.. & 475 & 345 & 82 & 48 & 72.63 & 17.26 & 10.11 \\
\hline
\end{tabular}




\section{CONSANGUINITY IN MARRIAGE.}

In looking over the marriage statistics in the Juke family, there are found 20 first-cousin matings, 20 secondcousin, 20 third-cousin, 8 fourth-cousin, and 1 fifth-cousin. There were in all 772 out-matings. Of all the matings, therefore, 9 per cent are consanguineous, an amount much less than that found in the Nams, which had 22 per cent. On analyzing table 5 closely it is seen that 23 per cent of the total matings in generation III are consanguineous. At that time the Jukes had not dispersed from their original home. The physical barriers prevented their seeking consorts from elsewhere, and the natural aversion of better families nearby toward the Jukes aided this consanguinity by forcing Jukes to marry Jukes. In generation IV we find only 20 per cent of consanguineous matings. In generation $\mathrm{V}$, with the beginning of the wholesale removal of the Jukes to other places, the amount of consanguinity drops to 12 per cent. In the Nams it will be remembered that little dispersal had taken place until recently and then not to such distant localities. The amount of consanguinity is decreased to 5 per cent in generation VI, which is scattered much more widely than generation $\mathrm{V}$; also many of generation VI are under marriageable age. In generation VII most of the individuals are still young.

As the Jukes in the sixth and seventh generations scattered here and there, they mated with other families rather than with their own, but they tended to marry like-to-like and where there was the common defect in the germ-plasm the out-rnatings into defective germ-plasms were as baneful in results as cousin-mating in Juke stock. Consanguineous marriages are less a cause of degeneration than an indication of the geographical barriers of a region that prohibit the free choice of mates and intensify the tendency of like to mate with like. The following cases of consanguineous marriages or matings will demonstrate the inheritance and accumulation of mental deficiency or feeble-mindedness in the final offspring:

CAsE A.-Bell Juke had a son Bruno (III 17), who was a farm laborer by occupation. All through his life he was poor. This may have been caused by his intemperate habits or his utter inefficiency. He married his cousin Carvilla, who was a daughter of Clara Juke. One of their children was Blanche, IV 76, who had a small, shrunken body, and, although reputed chaste, was blind from syphilis and, at the time of Dugdale's story, she was a pauper. She married her cousin Edmund, a grandson of Effie Juke. At the age of 18 and before his marriage, Edmund had been the father of a bastard boy. Edmund was ablebodied and physically in good health, but was inordinately lazy. The family trait of criminality appeared in him, for he served several terms in jail and was in State prison 5 years for assault with intent to kill (see Chart 7).

The marriage of Edmund and Blanche produced several children, two of whom are interesting at present. The first, Evelyn, was a densely ignorant woman who had several illegitimate children, one of whom, VI 845, was intemperate and generally inefficient as a laborer.

The second child of Blanche was Emerson. He was a criminal pauper and married his first cousin, Elmira, of Effie blood, who, though temperate, preferred a life of harlotry and disliked honest toil. This marriage produced, among others, VI 925, who was uncouth, a harlot like her mother, and ignorant. Following the scheme of Dugdale, the descent of VI 925 is indicated as B C E E X, while that of VI 845 is B C E X. These first cousins married and now have six children, all of whom are being brought up in neglect and with insufficient nutrition.

The oldest, VII 787, was mischievous and very backward in school. On leaving she went to work in a factory and soon became a harlot. At 15, while her mother was pregnant, her father committed incest with her. Later she was induced by a man to run away from home to a larger city nearby. Here she was arrested and committed to the State School for Girls, where she is at present.

The other five children are boys and the three old enough to attend school are underfed, anemic, and physically and mentally below normal.

The father is now under arrest for the rape of the child. He and his wife had moved away from the Juke region and all of their children were born in another State.

Continuous cousin-matings combined with a defective germ-plasm in the beginning has produced in this case a set of children blighted at birth, at first mentally incapable of grasping school work, and later of solving life's problems, and so socially handicapped through life.

TABLE 5.-Consanguinity in mating.

\begin{tabular}{|c|c|c|c|c|c|c|c|c|c|c|c|c|c|c|c|c|c|c|c|}
\hline \multirow{3}{*}{$\begin{array}{l}\text { Juke } \\
\text { genera- } \\
\text { ation. }\end{array}$} & \multicolumn{13}{|c|}{ Consanguineous matings. } & \multirow{3}{*}{$\begin{array}{l}\text { Total } \\
\text { consall- } \\
\text { guincous } \\
\text { matings. }\end{array}$} & \multirow{3}{*}{\multicolumn{2}{|c|}{$\begin{array}{c}\text { Out- } \\
\text { matings. }\end{array}$}} & & & \multirow{3}{*}{$\begin{array}{l}\text { Per eent } \\
\text { of eon- } \\
\text { sanguin- } \\
\text { cous } \\
\text { matings. }\end{array}$} \\
\hline & \multirow{2}{*}{$\begin{array}{c}\text { Brother } \\
\times \\
\text { sister. }\end{array}$} & \multirow{2}{*}{$\begin{array}{c}\text { Father } \\
\times \\
\text { daughter. }\end{array}$} & \multirow{2}{*}{$\begin{array}{c}\text { Uncle } \\
\times \\
\text { niece. }\end{array}$} & \multicolumn{2}{|c|}{$\begin{array}{c}\text { First } \\
\text { cousin } \\
\text { rcmoved. }\end{array}$} & \multicolumn{2}{|c|}{$\begin{array}{l}\text { Second } \\
\text { cousin } \\
\text { removed. }\end{array}$} & \multicolumn{2}{|c|}{$\begin{array}{l}\text { Third } \\
\text { cousin } \\
\text { removed. }\end{array}$} & \multicolumn{2}{|c|}{$\begin{array}{c}\text { Fourth } \\
\text { cousin } \\
\text { removed. }\end{array}$} & \multicolumn{2}{|c|}{$\begin{array}{l}\text { Fifth } \\
\text { cousin } \\
\text { removed. }\end{array}$} & & & & $\begin{array}{r}\mathrm{T} \\
\mathrm{mat}\end{array}$ & & \\
\hline & & & & 0 & 1 & 0 & 1 & 0 & 1 & 0 & 1 & 0 & 1 & & & & & & \\
\hline $\begin{array}{r}\text { II.. } \\
\text { III. } \\
\text { IV.. } \\
\text { V... } \\
\text { VII. } \\
\text { VII. } \\
\text { VIII. }\end{array}$ & $\left.\mid \begin{array}{cc}0 & 1 \\
\cdots & \ldots\end{array}\right]$ & $\begin{array}{cc} & \left.\begin{array}{cc}0 & 3 \\
0 & 2 \\
0 & 2 \\
\ldots & \ldots\end{array}\right] \\
\ldots & \ldots\end{array}$ & $\begin{array}{cc}0 & 1 \\
0 & 2 \\
\ldots & \cdots \\
\ldots & \cdots\end{array}$ & $\mid \begin{array}{cc}4 & 1 \\
2 & 0 \\
6 & 1 \\
1 & 0 \\
0 & 2 \\
\cdots & \ldots\end{array}$ & $\begin{array}{ll}2 & \\
2 & 1 \\
\cdots & \end{array}$ & $\mid \begin{array}{cc}3 & 3 \\
1 & 0 \\
3 & 6 \\
\cdots & \cdots \\
\cdots & \cdots\end{array}$ & 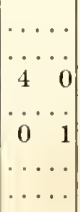 & $\left|\begin{array}{cr}1 & 0 \\
\ldots & \cdots \\
12 & 2 \\
1 & 0 \\
\cdots & \ldots \\
\cdots & \cdots\end{array}\right|$ & $\begin{array}{l}\cdots \\
4 \quad 0 \\
\cdots \\
\cdots \\
\cdots\end{array}$ & $\begin{array}{ll}{ }^{6} & 1 \\
\cdots & \cdots \\
\cdots & \cdots\end{array}$ & $\left|\begin{array}{cc}\cdots & \cdots \\
1 & 0 \\
\cdots & \cdots \\
\cdots & \cdots\end{array}\right|$ & $\begin{array}{cc}1 & 0 \\
\cdots & \ldots\end{array}$ & & $\begin{array}{rr}5 & 1 \\
14 & 3 \\
25 & 8 \\
12 & 6 \\
1 & 3 \\
\ldots \ldots\end{array}$ & $\begin{array}{r}5 \\
16 \\
56 \\
136 \\
228 \\
58 \\
2\end{array}$ & $\begin{array}{r}0 \\
4 \\
12 \\
109 \\
104 \\
39 \\
3\end{array}$ & $\begin{array}{r}5 \\
21 \\
70 \\
161 \\
240 \\
59 \\
2\end{array}$ & $\begin{array}{r}0 \\
5 \\
15 \\
117 \\
110 \\
42 \\
3\end{array}$ & $\begin{array}{r}00.000 \\
23.077 \\
20.000 \\
11.870 \\
5.143 \\
3.963 \\
0.000\end{array}$ \\
\hline Total. & $\begin{array}{ll}0 & 1\end{array}$ & $\begin{array}{ll}0 & 5\end{array}$ & $\begin{array}{ll}0 & 3\end{array}$ & 134 & 21 & $12 \quad 3$ & $\begin{array}{ll}4 & 1\end{array}$ & 142 & 40 & $\begin{array}{ll}6 & 1\end{array}$ & 10 & 10 & & $57 \quad 21$ & 501 & 271 & 558 & 292 & 9.176 \\
\hline
\end{tabular}

Note.-Number at left of column indicates the number of matings which produced children; the number at the right indieates the number of matings without offspring. 
CASE B.-Another example of close cousin-mating shows the same general result. Originating the same as Case A, with the consanguineous mating of Bruno and Carvilla, we take this time a daughter, Bessie. Bessie was a white girl and was brought up in the home of her half-uncle Bob, a mulatto, who had acquired property. Here she lived well until, at 18 , she left her home, became immoral, and finally married her cousin Dexter. He was a laborer and his meager wages could not support Bessie and her five children. She was forced to ask for town help, which was given her. Later her husband died, leaving her with these young children, but she soon procured a paramour. This man, Lon, IV 73, was a drunken pauper and he increased Bessie's burden in life by fathering two children to her, one a dwarf. Two of Bessie's children matured into fairly good citizens, while three possessed the Juke traits and were anti-social (see Chart 8).

\section{Gen.}

II.

III.

IV.<smiles>[C]1CCCCC1</smiles>
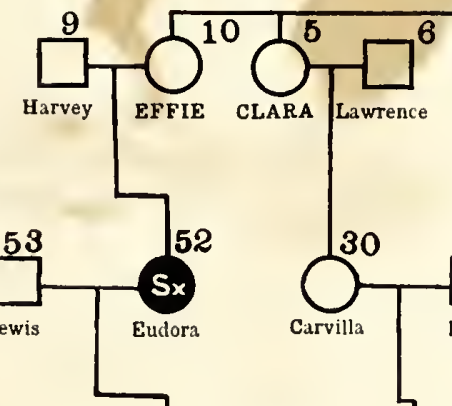
Clara Lawrence BELL

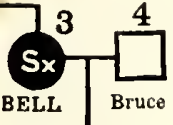

V.

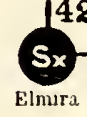
423
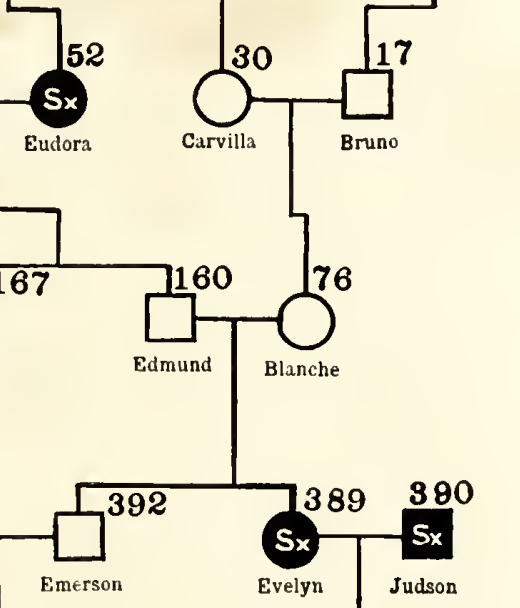

VI.

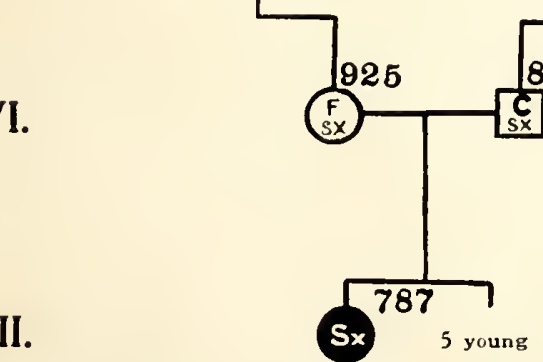

Chart 7.-Group of Jukes showing baneful effect of consanguinity. in a defective germ-plasm.

Sx, Liecntious. A, alcoholic. F, feeble-minded. C, criminal.

Levan, the second child of Bessie by Lon, and brother of the dwarf, married his cousin Imogen. She was reputable and temperate at that time, but ignorant and poor. Her father, Ben, possessed these same qualities and was blind. He was a brother of Bessie, mentioned above, and married Ann. Ann was reputable and in turn was a product of the first-cousin mating of an indolent syphilitic and a chaste woman (these two being the children of Ada and of Clara respectively).
As an aside, it miglit be mentioned that after Imogen died Levan cohabited with a vicious woman. Ile adopted a young girl of 13 , but shortly after she canne to his house he violated her.

But to return to the main line of the story, Levan and Imogen had three children.

The first, VI 287, is immoral, shiftless, and easy-going. Her husband is a humberman and wanders here and there. They live in abandoned houses or in shacks in lumber camps. Their three children, all of whom are boys, were incapable of learning in school and will grow up unskilled, unlettered, and generally handicapped in life.

The second child of Imogen and Levan, VI 288, was sent to the county jail for burglary for six months. He escaped from jail, and upon being apprehended was sent to State prison for one year. He is an ignorant laborer, is narried, and has two young children.

Gen:

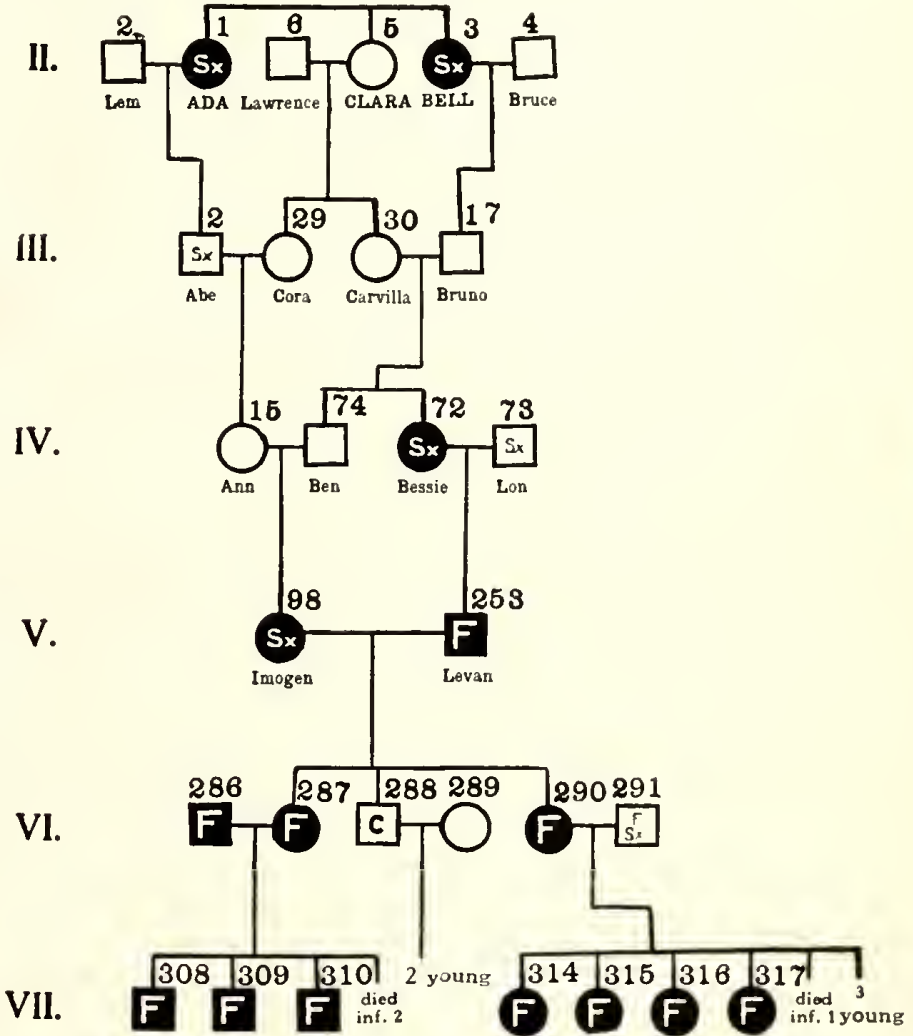

Chart 8.-Group of Jukes showing baneful effect of consanguinity. in a defective germ-plasm.

Sx, licentious. F, feeblc-minded. C, criminal.

The third child of Imogen is much like her sister, inefficient and immoral. She cohabited with VI 291, and has seven children. Their father is rather industrious, has some small schooling, and with a wife who could help "would be quite a man." As it is, the family is in filth, the children are underfed and half-clothed, and those attending school are retarded.

Here is a group of socially unfit individuals who have been and are still being produced through cousin-matings of defective germ-plasms.

CAsE C.-In the series of cousin-matings described, the first five generations lived in the ancestral forest-framed five-lake region. In generation VI a shight dispersal from 
the Juke region took place, but the cousin marriages still continued, as the Jukes could find mates only in their own social class and propinquity threw them with relatives.

Chart 9 shows the interweavings of the germ-plasms and the ancestry of two males, VI 529 and VI 531. The former never attended school and can neither read nor write. He has no reasoning ability, is lazy, and spends in drink what little money he can secure by work or begging. He married a feeble-minded woman of low grade, and had several children. At the age of 33 he broke a window in a store in order to steal groceries. He was caught in the act and sent to State prison for 4 years. Upon release he returned to his family, which, during his incarceration, had subsisted by begging and stealing. Several years ago the wife, who frequented brothels, was frozen to death while returning one winter night to her hovel home in the mountains. Her oldest child is feeble-minded and has been a prostitute many years. The younger was taken to the brothel by her mother, who trained her to prostitution. This child, then 18, was arrested for disorderly conduct and sent to a reformatory. A psychological examination developed the fact that she was mentally defective, so much so that institutional training could have no beneficial effect upon her, and she was refused care at the institution. She was then placed in the county almshouse and the problem of her future was settled by committing her to a custodial asylum.

VI 531, who heads the other line, is much like his brother. He is called "Lazy Bob." When young he was in a reformatory for burglary. He sold his first wife (of " $\mathrm{X}$ " blood) to his cousin for a pint of whisky and 50 cents. He then cohabited with a cousin, VII 19, who was a product of the numerous cousin marriages shown on the chart. She had been unable to acquire even the simplest knowledge in school and at an early age became immoral. They had five children, the oldest of whom died young. When the youngest child was about a year old the mother was arrested for prostitution and sent to a reformatory. The father then deserted the children and wanckered about the country. Then three of the children,

Gen. II.

Gen. III.
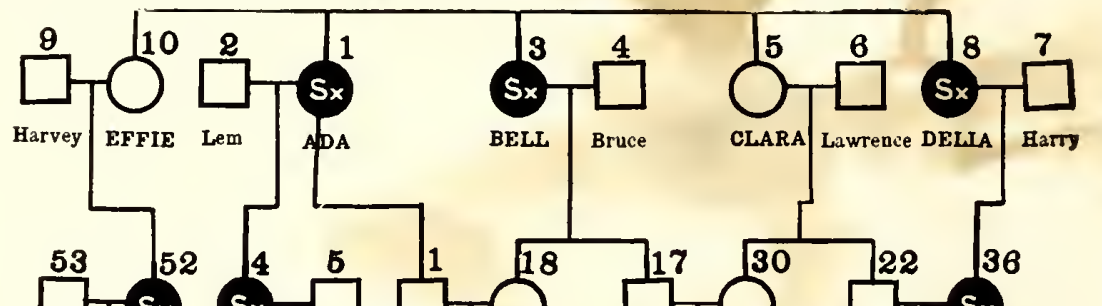

Gen. IV.
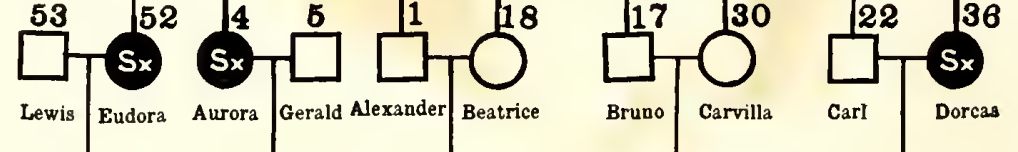

Gen. V.
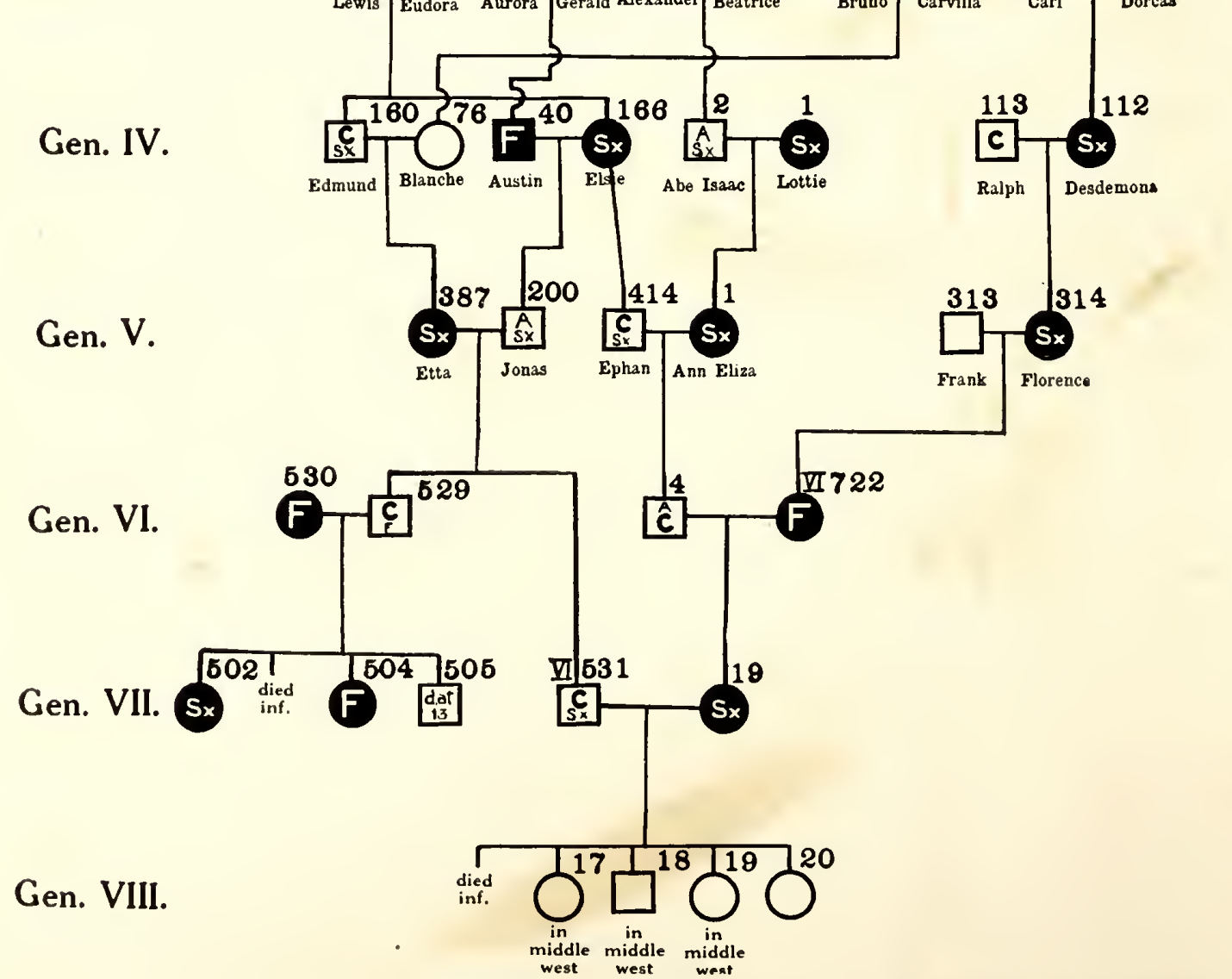

Chart 9.-Group of Jukes showing baneful effect of repeated consanguinity in a defective germ-plasm. Sx, licentious. A, alcoholic. C, criminal. F, feeble-minded. 
aged 6,3 , and 2 , respectively, were put into a Children's Home and are now in foster lomes in the West. The oldest, now aged 9, is of normal intelligence by the Binet test, but, although she has attended school regularly for the past three years, is in the second grade only. Her brother, aged 6 , is in the first grade. They are both wellbehaved children. The other child is still young. The fourth child of VI 531 and sister to the children just mentioned, is with her grandmother, VI 722, in a home where there is prostitution, intemperance, and poverty. It will be interesting to study these children in the future and, in view of their similar heredity and different environments, to compare the results.

Case D (chart 10). - This case seems to oppose the statement made at the beginning of this section as to the banefulness of cousin-matings of the Juke blood, for two successive cousin marriages from defective stock here produce offspring some of whom were more active and intelligent than any of their immediate ancestry, while others are mentally retarded or deficient like their ancestors.

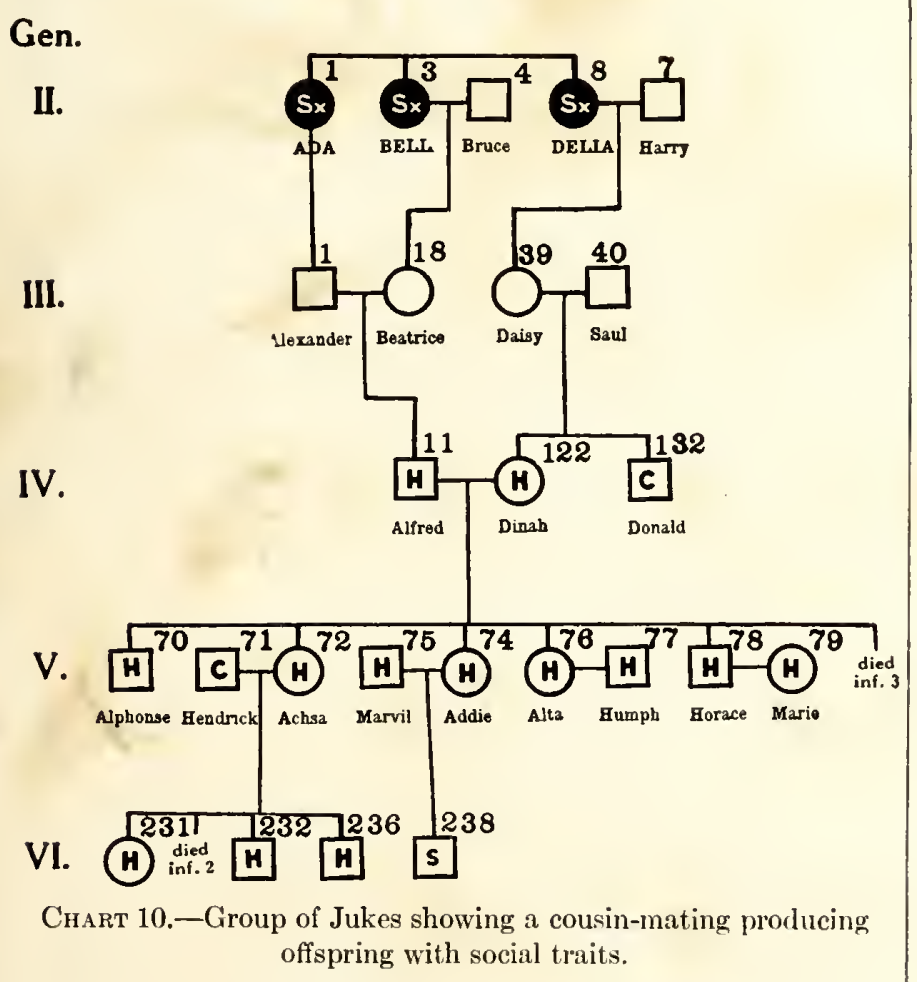

Sx, licentious. $H$, self-controlled, or honest. C, criminal. S, syphilis.

The fifth child of the cousin marriage of Alexander and Beatrice (charts 1 and 10) was Alfred. He was an industrious mason who, although occasionally intemperate and receiving poor relief for three years while in middle life, was a much better citizen socially than any of his brothers or sisters. Each one of these had married into " $\mathrm{X}$ " blood, and the resultant $F_{1}$ generation (Gen. $V$ ) was markedly characterized by criminality. Alfred married his second cousin Dinah, of Delia blood, who had two brothers who were criminals. Dinah was ignorant and was addicted to the use of opium but not of alcohol. Unfortunately, I could secure no other exact information in regard to the mentality and traits of Alfred and Dinah.
The first child from this cousin marriage, Alphonse, was industrious, acquired property, and was a goorl eitizen.

The second, Achsa, was reputable. She was a tailoress and was well liked by her employer. She married Hendrick, an industrious man, but one who at 23 was scnt to State prison for murder in the fourth degree (killing a woman while under the influcnce of liquor). They had three children.

The first was reputable with a reputable daughter who does good work in the high school.

The second was industrious but inefficient and had children who were very slow in school and were deficient in ideas of causation.

The third, a son, VI 236, was sent to jail at 29 for assault while intoxicated. Since this he has been a good citizen.

The third child of Dinal, Adclie, acquired syphilis from her husband and their one son was a syphilitic pauper who died of consumption. She was a tailoress and, like her sister, was well thought of by her employer and always bore a good reputation. She died at 28 of syphilitic consumption.

Alta, the fourth child of Alfred and Dinah, was industrious and bore a good reputation.

All of the other four children died young except Horace. He was industrious and worked for the same man for many years. He saved little money, but reared nine children, finally dying of paralysis. All of these nine children attended school until they reached the age of 14 , when they left and went to work. They tried hard to get along in school, but were several years retarded in their work. The adult ones are industrious and reputable men and women.

What is the environment in this case? On page 22, Dugdale, in discussing this group, under Harlotry, points out that Alfred had separated himself from his brothers and sisters, whose environment was one of prostitution and crime. Although generations $\mathrm{V}$ and $\mathrm{VI}$ in case $\mathrm{D}$ lived only 5 miles from the old Juke home, they have associated but little with their less worthy relations. The descendants of the cousin marriage of Dinah and Alfred have not become anti-social like their cousins. This is not due merely to better environment, but also to innate tastes which lead this branch to select a better environment. Alfred at least, and probably Dinah, carry in their germplasm certain elements for social traits, and these alone have, by chance, united in the children and the worse elements have been eliminated. The next generation, $\mathrm{V}$, married into slightly bettcr stocks. If eugenic marriages continue it may be expected that this branch of the Jukes will soon have eradicated from its gcrm-plasm most of the determiners for undesirable traits.

There wcre no cousin marriages among the few Jukes who had only good mental and moral traits in their immediate ancestry, and so this side of the cousin-mating problem can not be discussed in this paper. The inference can be drawn from the above studies that cousin marriages in lines where there is mental defect tends to reproduce that defect and intensify it; but where there is mental and moral strength in certain character's on both sides there may, in certain matings, arise offspring who are superior to either parents. 


\section{STUDIES IN SPECIAL TRAITS.}

\section{(Charts 11 to 27.)}

\section{Harlotry.}

It will be interesting to take the mere aggregate figures of harlotry and compare the Jukes of to-day with those living previous to 1874. Table III of Dugdale's book shows that 84 of 162 marriageable women in the Juke blood were harlots, making a percentage of harlotry of 52.4. To-rlay there are 541 female Jukes of marriageable age (including those of Dugdale), 277 of whom have been harlots, or 51.20 per cent. (Sec table 6.) It is obvious from these figures that harlotry has decreased but little in the Juke blood. In order, however, to draw any valuable conclusions in regard to inheritance of harlotry in this family, it will be necessary to examine the data in detail.

TABLE: 6.-Harlotry in Juke blood.

\begin{tabular}{|c|c|c|c|}
\hline $\begin{array}{c}\text { Genera- } \\
\text { tion. }\end{array}$ & $\begin{array}{c}\text { Iarriageable } \\
\text { women. }\end{array}$ & $\begin{array}{r}\text { Aggregate } \\
\text { of harlotry }\end{array}$ & $\begin{array}{c}\text { Percentage } \\
\text { of harlotry. }\end{array}$ \\
\cline { 1 - 3 } II & 5 & 3 & 60. \\
III & 16 & 6 & 37.50 \\
IV & 39 & 27 & 69.23 \\
V & 118 & 85 & 72.03 \\
VI & 221 & 113 & 50.45 \\
VII & 129 & 41 & 31.78 \\
VIII & 10 & 2 & 20.00 \\
\cline { 2 - 3 } & 541 & 277 & 51.20 \\
\hline
\end{tabular}

Dugdale described and discussed many cases very fully. He showed how here heredity and there environment had affected the inclividual. In the 40 years that have elapsed since Dugdale published his results, two generations of people have been produced. Taking his eases, then, as a beginning, a summary and (liscission of what has followed in each case will be given.
Case E.-This is case 1 of Dugdale, who says:

"Taking up the legitimate branch of Ada, which intermarried into Bell and Clara [chart II], we follow the heredity of legitimacy in lines 6,8 , and 10 , generation 5 . They are three sisters [all chaste; Mary Eliza, V 90; Imogen, V 98; and Hulda Ann, V 103], children of a legitimate father [Ben, IV 74], and a chaste and legitimate mother [Ann, IV 15], whose mother [Cora, III 29] (generation 3 following the mother's side) was a chaste and legitimate daughter of Clara, who was chaste. Going back to the father [Ben], we find his mother [Carvilla, III 30] was a chaste, legitimate daughter of Clara. Both parents, therefore, of generation four, were of chaste descent on the mother's side. Thus the original characteristic of "chastity seems to have descended from Clara through two branches, A and $\mathrm{B}$, and cumulated in the three sisters under consideration. Further; we find, in line 7 [Isabella, V 97], the sister of the above three to be a prostitute, and in going back upon the heredity, we find in generation 4 that the mother's father was a licentious, though legitimate, son of Ada, a harlot, and on the father's side, the father [Bruno, III 17], was the legitimate son of Bell, a prostitute. According to the law of heredity, it is a logical deduction to make, that line 7 [Isabella] has reverted to the ancestral types on the unchaste side of both parents. Respecting this case, very little reliable information has been gathered about the environment, but it must be noted that the mother in generation four was one of seven sisters, one of whom was idiotic and no doubt licentious, and five others, harlots or prostitutes, one of them keeping a brothel; while, on the father's, there was one sister [Brunhilde, IV 68] who also kept a brothel. Whether this pair removed from the vicinity of their relations has not been learned, and what were the other particulars of their career are unknown. This case looks more like one of pure heredity than any that has been traced." (Dugdale, page 20.)

Gen.

II.

III.

IV.

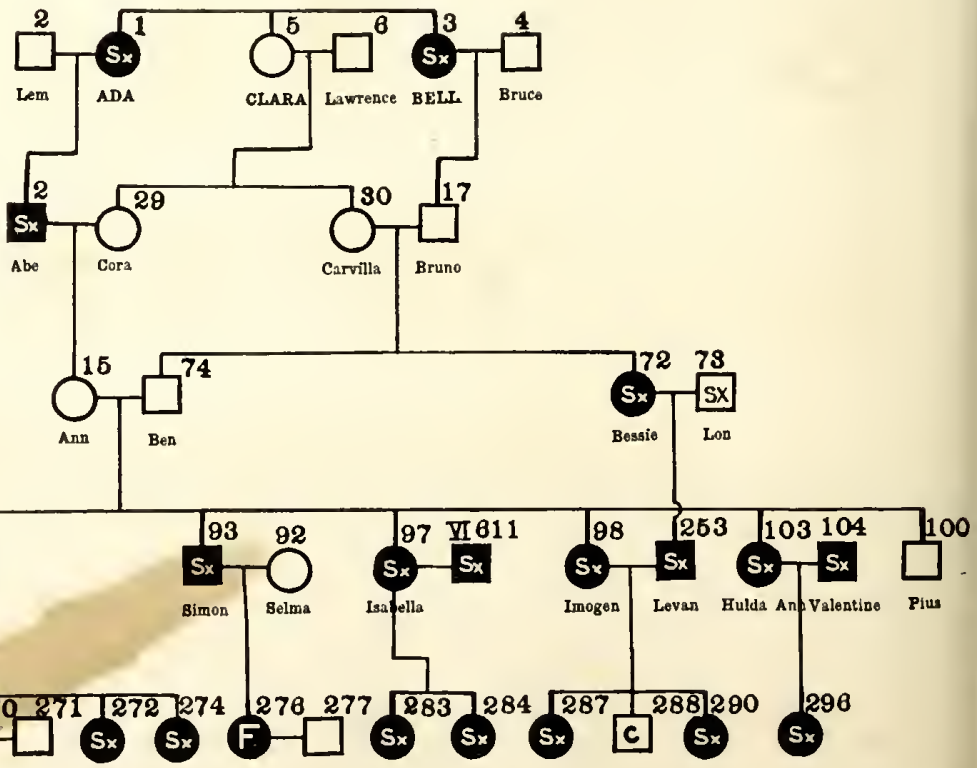

Chart 11.-Group of Jukes showing occurrence of sex offense.

Sx, licentious. A, alcoholic. F, feeble-minded. C, criminal. 
The history of the three sisters since the time mentioned by Dugdale will now be given.

Mary Eliza, V 90, has always been chaste. She married an intemperate, chaste man from out blood. They had five children: one boy, who was chaste, and four girls, all of whom became harlots before marriage but were chaste afterwards. The son, VI 266, has two daughters, aged 19 and 12 , now chaste.

The second child of Mary Eliza, VI 268, had three girls and one boy, the okdest girl a harlot before marriage but chaste since. The boy is chaste and the two other girls are now adolescent.

The third child of Mary Eliza, VI 270, has two girls now chaste, the older of whom is 16 . The other two have no adult offspring.

Imogen, V 98, married her cousin Levan, who was licentious and a descendant of Bell the prostitute and Clara the chaste; they had three children. After her husband deserted her she lived with other men. Two of her children were harlots and one boy has been in State prison. The second generation from Imogen is still young.

Hulda Ann, V 103, the third of the three sisters mentioned by Dugdale as chaste, was 14 at the time he wrote. She married when young, but descrted her husband and has cohabited for many years with Valentine. They have one bastard girl, VI 296, who knows of the illicit relations of her parents and has recently become a harlot.
A study of the sibs of these three sisters throws additional light upon the composition of the germ-plasm. They had one brother, Lloyd, V 88, who had four children by a chaste woman. After her death, and while the children were still young, he cohabited with Nora.

The oldest child of the first mating, VI 256 , was 15 at this period. She grew up to be a harlot. She had four children by one man. These have been taken away and are growing up industrious, capable, and active. One of these, a girl, VII 277 , is neat, chaste, and artistic.

The second child of Lloyd is an actor and wishes to divorce his wife that he may marry an actress with whom he is enamored.

The third, VI 261, was a harlot before marriage and was sent to an institution for wayward girls. She married, had five children, and is now clandestinely a prostitute. A son of Lloyd is hicentious.

Another brother of Mary Eliza is Simon, V 93, who was always licentious and had one feeble-minded daughter.

An analysis of chart 11 shows that licentiousness is probably carricd in the germ-plasms of both chaste ancestors, Ann and Ben, for 5 of their descendants were licentious, while only 1 was chaste and this one carried licentiousness which appeared in 4 of her 5 children.

In the second generation from the Ann-Ben mating, licentiousness has appeared in 13 of the 16 offspring.

Gen. II.

Gen. III.

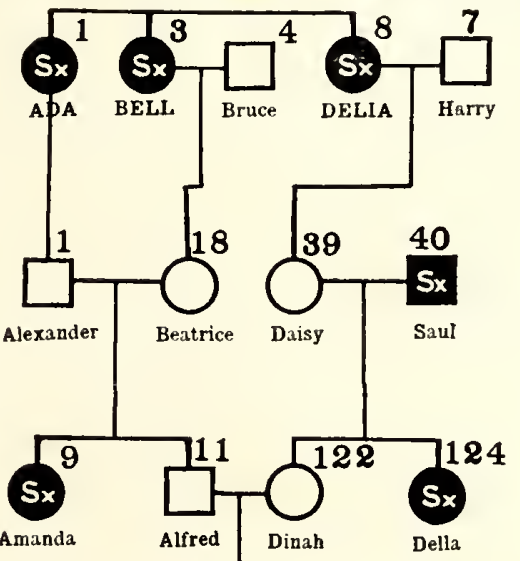

Gen. IV.

Amanda

Alfred Dinah Della

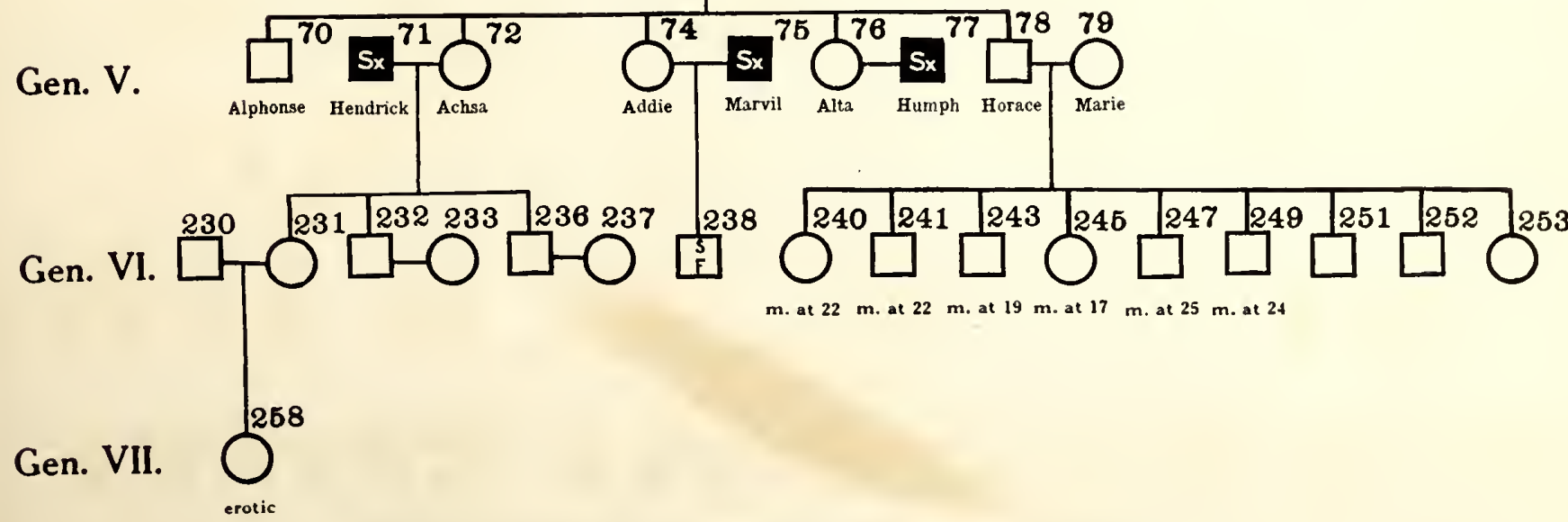

Chart 12.-Group of Jukes showing occurrence of sex offense and chastity.

Sx, licentious. S, syphilis. F, feeble-minded. m. at 22 , married at 22 . 
Mary Eliza, who was cliaste and married a chaste man, had a daughter who was licentious before marriage and she, in turn, had a daughter who was licentious before marriage but chaste afterwards.

This case suggests the inheritance of sex offense. The consanguineous marriage of two chaste individuals, both of whom may carry a determiner for licentiousness in their germ-plasms, has produced a progeny which has shown licentiousness to the third filial generation.

CAse F.-Dugdale's case 2 discusses the children of Lavinia, V 112, and he shows how an environment of harlotry parallels the heredity of licentiousness and that this environment alone is sufficient to produce the effects found. I have no further data in regard to Lavinia and for that reason this case will not be further discussed.

CASE G (case 3 of Dugdale).- "Turning to the illegitimate branch of Ada [charts 1 and 12], trace the heredity of legitimacy in" a girl [VI 231], and a boy [VI 238], "who are legitimate, whose mothers [Achsa, V 72, and Addie, V 74] were sisters, chaste and legitimate, whose father [Alfred, IV 11] and mother [Dinah, IV 122] were legitimate and chaste, whose mother, Beatrice, following the father's side was legitimate and chaste, whose mother was Bell, a harlot. Here the heredity seems not entailed."

Now for the environment. The three sisters of generation $\mathrm{V}$ are industrious women, rehiable and capable. Their oldest brother is a mason and has acquired a house and lot. He is steady and industrious. His father, Alfred, in turn, was a steady, industrious man who left the environment of his brothers and sisters, which was one of harlotry, intemperance, and crime. Alfred lived only a few miles from the Juke country and yet his children grew up chaste and industrious, while the children of his brothers and sisters, still in the Juke country, became harlots and criminals.

Let us see what the descendants of Alfred have been in the past 40 years.

A glance at the chart for this case shows a cousin-mating of chaste indivichuals was followed in the first generation by no licentiousness. In the second generation from the cousin-mating, no licentiousness appears, although the father of one of the children in this generation had cohabited previous to marriage. Their one daughter, VI 231, was chaste, but she has one daughter, brought up in a good home free from bad influences, who was very erotic, but is at present chaste (see Chart 12).

The third child of this cousin-mating of chaste people, Addie, married a man who had acquired syphilis, and had one son, an inefficient syphilitic, who died of tuberculosis. Addie died of syphilis at 28.

The fourth child, Alta, V 76, who was always chaste, married but had no children.

Horace, the only other child of Alfred who reached maturity, was reputed chaste but was intemperate; he married a chaste woman and had nine children, all of whom are chaste; they married young, and the ages at which they married are given on chart 12 . Whether the early age at which each one married is correlated witl any sexual inheritance is not known.
Heredity of chastity here seems assured in the main. In the Alfred-Dinah mating licentiousness might have come from four separate sources-Ada, Bell, Delia, and Saul. Sex offense shows in the sibs of both Alfred and Dinah (gen. IV). Only one case of eroticism appears in the descendants of this mating, and that in generation VII, no cases appearing between.

CASE H (case 4 of Dugdale, $c f$. chart 13).- "Taking [VII 238], we have an illegitimate child, wliose mother" [VI 217] was a prostitute, whose mother [Abigail, V 67] was a bastard prostitute, whose mother [Amanda, IV 9] was a harlot, whose father [Alexander, III 1] was a bastard son of Ada, a harlot, while his wife, Beatrice, was the legitimate child of Bell, a prostitute. Going back and following up from the father in generation four [Benjamin] we find his father [Brown, licentious and] the illegitimate son of Bell."

\section{Gen.}

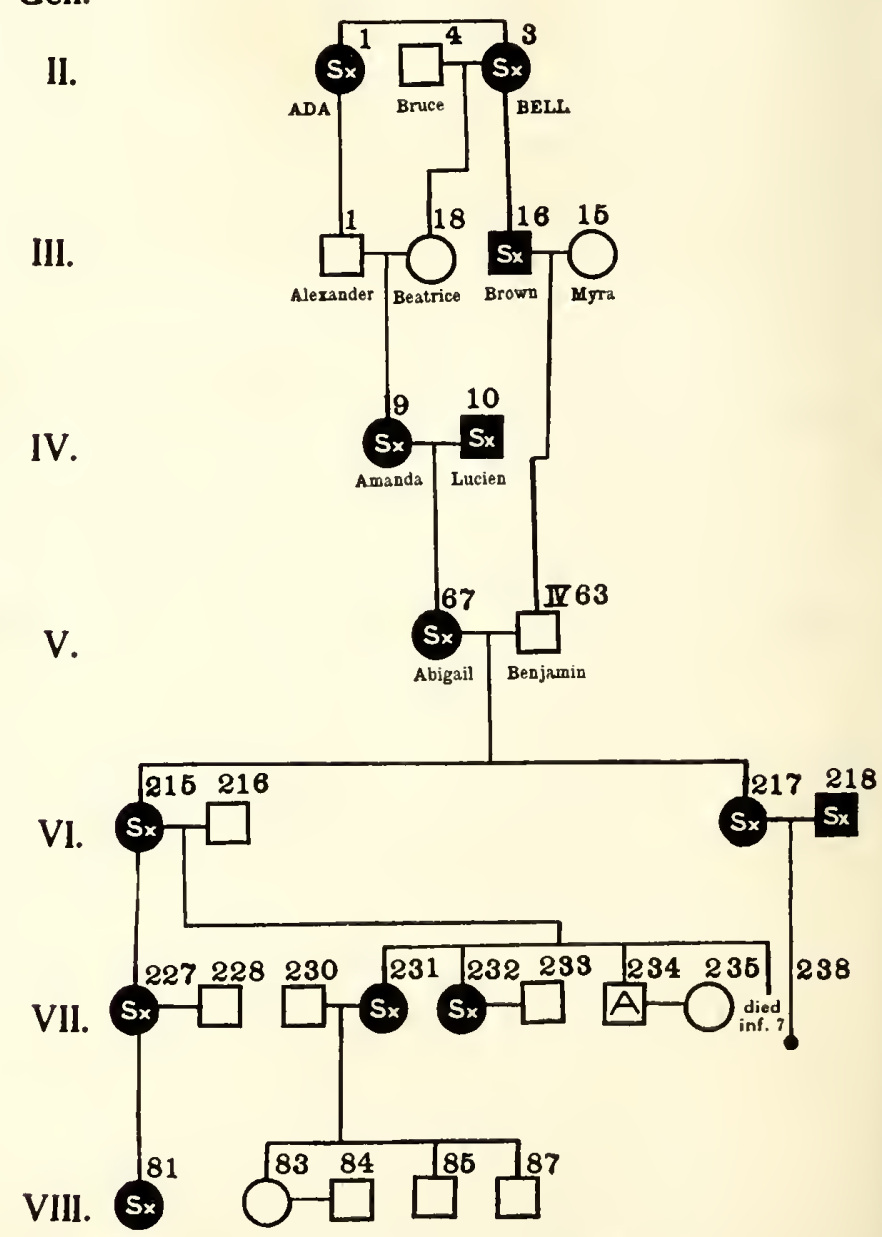

Chart 13.-Group of Jukes showing occurrener of sex offense.

$$
\mathrm{Sx} \text {, licentious. A, alcoholic. }
$$

The environment was as follows: "The mother of this child in the seventh generation is the daughter of a prostitute who kept a brothel when that daughter was only ten years old. It is stated by one of the poor-masters that, upon one occasion, the daughter applied to him for out-door relief to maintain the above child. She made a charge of bastardy against a certain man, whom the poor-master was called upon, in virtue of his office, to 
prosecute for the maintenance of the child. The case was lost and after the trial was over in the magistrate's office, the male witnesses adjourned to a neighboring bar-room where, for a few dollars, the mother caused her daughter to retract the story publicly. Going back to the fourth generation, the testimony as to environment is not so complete, only that the father was dissolute, and that the example of the other sisters no doubt had an influence in blunting the sense of purity, while, in the two generations farther back, the testimony is not sufficiently definite for the purposes of the present argument."

"Here, again, environment is in the line of heredity."

This woman, VI 217, had no more offspring and this one child, above mentioned, died very young. Her older sister, VI 215, was a harlot and had four illegitimate children. 'Three of these died young, while the fourth, VII 227, has always been a prostitute and an inmate of brothels. She, in turn, has one bastard child, now 27 , who is a prostitute and is reputed to be rumning a brothel.

By a chaste father, VI 215 has three legitimate children who grew to maturity. 'The oldest, VII 231, was a harlot before marriage, but since has been faithful to her husband, who is chaste. She has one daughter, now 21 , married and chaste always. The next, VII 232 , has been a prostitute, after as well as before marriage. The third, a son, VII 234 , is intemperate and is now married, but the marriage is not congenial.

Gen.

II.

III.

IV.

V.

VI.

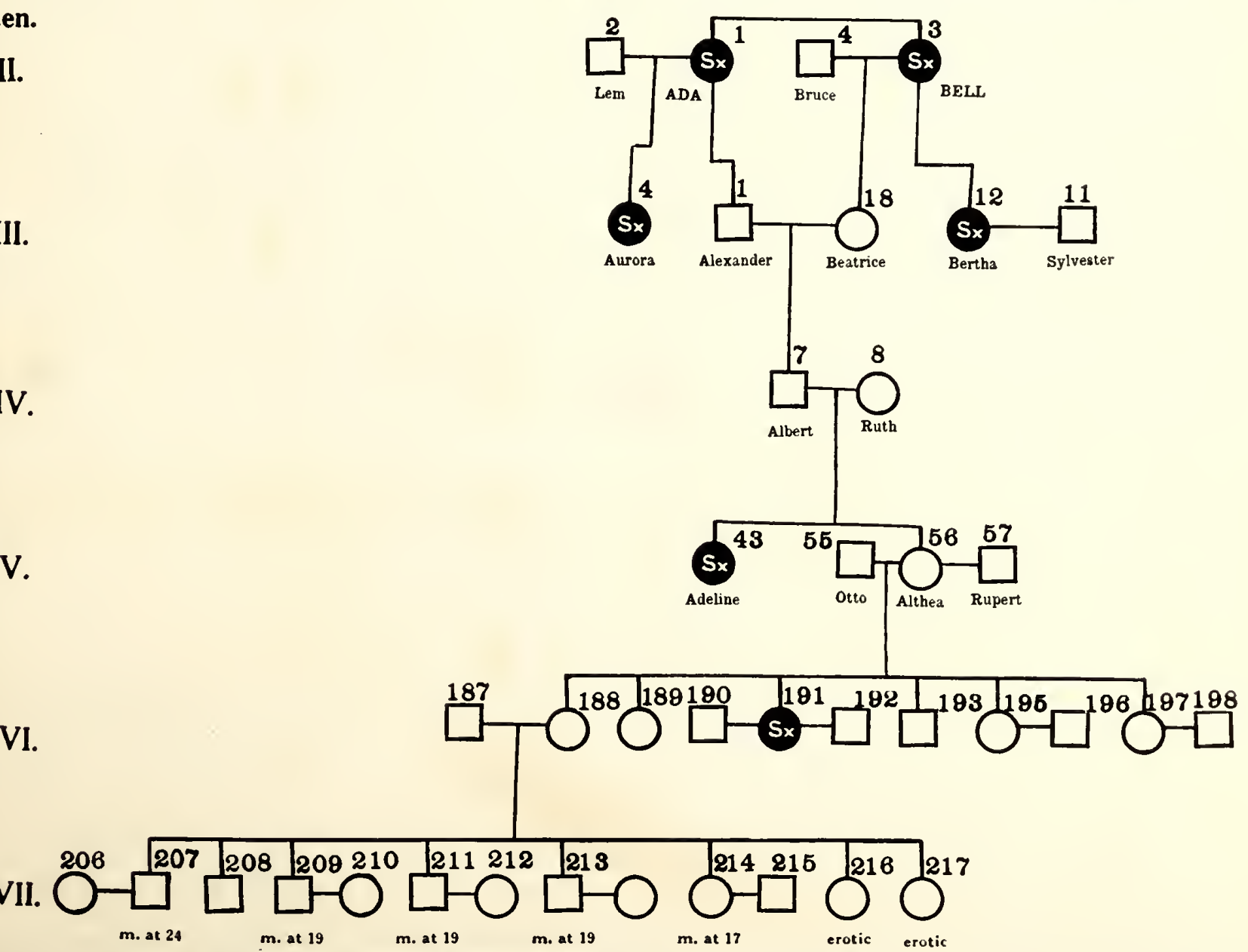

The three legitimate children of VI 215 were brought up in a manufacturing city quite distant from the Juke country. They associated when young with their older half-sister, who had learned to be a prostitute in the Juke country.

Here the environment runs parallel with the heredity up to the seventh generation, and with the changing of the environment and a chaste heredity on the side of VII 230 , we find chastity developed in the offspring. Here, too, the environment and the heredity are parallel.

CASE I (case 6 of Dugdale, $c f$. chart 14).- "Now we take a quite different case, where the heredity and the environment have coincided up to a certain age, and yet the eareer of harlotry has not been run. Follow line 30, chart I, to generation 5, is a girl [Althea, V 56], the sister of the woman in case 5 [Adeline, V 43], mentioned above, who kept a brothel and whose heredity has been traced. Substantially, the environment was the same as that of her two sisters who were both prostitutes. How closely she followed them up to her fifteenth year is shown by the fact that in 1861 we find her, together with her sister, arrested for vagrancy and locked up in the county jail for two days. At this point, however, the environment changes. She marries [Otto, V 55] a German, a cement burner, a steady, industrious, plodding man, settles down

CHart 14.-Group of Jukes showing how moral training has inhibited the anti-social behavior of a germ-plasm which has been and is still producing hypererotic individuals.

Sx, licentious. m. at 24 , married at 24 . 
into a home, brings legitimate children into the world and takes the position of a reputable woman. In this case it is claimed that the change in the environment has supplanted the tendency of the heredity. The case now is to be watched to see if, in spite of the environment of a reputable home, the daughter of this woman, now 12 years of age, will revert to the ancestral characteristics, and change what now seems to be an argument in favor of the potency of environment into an argument proving the prepotency of heredity."

This case indeed, as Dugdale has said, is interesting to study. In it are revealed many interesting facts bearing on the problem of the inheritance of sex behavior. Let us look at the facts first.

Althea had, in all, six children. At 44 her husband was accidentally killed while intoxicated and for two years following this Althea was intemperate. At 46 she married Rupert, then 22 years of age, and became temperate. This no doubt was a purely sensuous mating. She deserted him two years afterward, as the union was not happy. An analysis of Althea indicates that she was of all crotic make-up, but that a normal sexual life with a man of similar eroticism, and with frequent experiences of motherhood, led her to respond normally to the mores. Married at 15, the influence of her husband toward good living and her sexual satiety kept her faithful to her husband. Here environment cover's heredity to the extent of making the individual social.

Her sister, Adeline, had, perhaps, the same sexual activity and a less fortunate sexual hife. Her mother ran a brothel, licentiousness was the accepted rule of the house, and Adeline was trained to the career of harlotry. No moral restraint or example was imposed on her in her early years or at any other time. Her one daughter was raped at 14 by her uncle in her mother's brothel and this girl, later in life, became a harlot.

What is the sexual history of the descendants of Althea? The first daughter, VI188, was ahways chaste. She married at 18. 'The second died young. The third, VI 191, married, but the union was not happy and after her husband became insane she cohabited with another, but was faithful to this second consort. I have no sexual history of the fourth, a boy, VI 193. The fifth, VI 195, was "interested in the boys" when a girl. She was ahways chaste and married at 22 . The last, VI 197, is a chaste, refined girl who married at 25 . In this generation, then, licentious traits in an anti-social direction are for the most part inhibited.

The second generation from the Althea-Otto mating is interesting. 'The first daughter of Althea, VI 188, malried, at 18, a rather refined and chaste man. They had eight children: the first five were boys, and the last three girls. Socially all of them are chaste but one. The first married at 24 and had one child. The second never married; the third married at 19. The fourth, at 19, was compelled to marry in order to legitimize his bastark child. The fifth married at 19 . The first girl married at 17. The other two girls, now aged 17 and 14 , are erotic and sexually excitable, but still chaste.

It is probable that this early marrying of the eldest ancl the eroticism in the two youngest in this fraternity are remnants of the licentiousness in generation $\mathrm{V}$ of their ancestors, so inhibited by moral and ethical training and good social customs as to make the individuals chaste socially. To my mind there is no doubt as to inheritance of eroticism in this group; but the environment affects behavior so that it is not undesirable socially. In other words, while inhibitions are not very strong, there is also present no exceptionally strong stimulus to anti-social acts.

After discussing Dugdale's cases in the light of the past 40 years since his study, it will be of value to cite other cases of interest. The first is Case $\mathrm{J}$.

CASE J.-VI 754 is a well-built, strong, active woman who had many chikdren by her husband Edgar, a distant cousin. (See chart 15.) After this she became promiscuous in her sexual relations for a period of about six years and had one illegitimate child. Some time after her husband's death she married again and is now again bringing forth legitimate chilchen. Her sister, who las always been chaste, married a brother of Edgar. Their father and mother were both licentious. While his wife was separated from him and prostituting, Edgar had immoral relations with his "housekeeper," with young girls who visiterl at his house, and with his two oldest daughters. For this he was sent to State prison, where he died. Eslgar had thrce sisters who were harlots.

Gen.

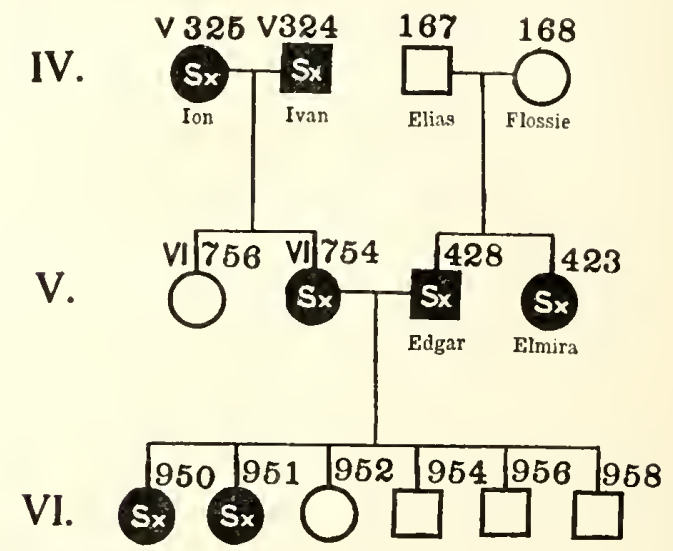

Chart 15.-A small pedigree showing inheritance of sex offense. The three boys in generation VI are still young. Sx, licentious.

Edgar and VI 754 had nine children-three girls and three boys, and three others who died in infancy. The oldest, at 13, had immoral relations with her own father. She became a prostitute, but is now married and chaste. The second was a harlot and also committed incest with her father. She was committed at several times to different institutions, but, after discharge, each time returned to her wayward eareer. She died at 22 . The third girl was 12 when the home was broken by the father's arrest for rape. She was removed from her immoral surroundings, was placed in a good religious home in the Middle West, and at 18 is moral and chaste. The three boys were also removed and placed in good homes in the Middle West, but are troublesome and do not get along well. When olker their sexual behavior will be of interest.

Case K. - In Case K (chart 16) we find the following history: Beginning with Eudora, a harlot, and daughter of Effie, we trace a daughter, Ella, who married at 15 and was faithful to her husband. She had several licentious children and one chaste daughter, Elvina, who married a 
chaste man. The first two of the four daughters born to this couple were chaste. The third, VI 963, an casy-going but not vicious girl, has worked hard to support her two illegitimate children. The fourth was immoral as a young girl, but is now married and faithful to licr lrusbancl. Further than that the four girls were brought up in a home free from vice and crime, nothing is known of the immediate enviromment.

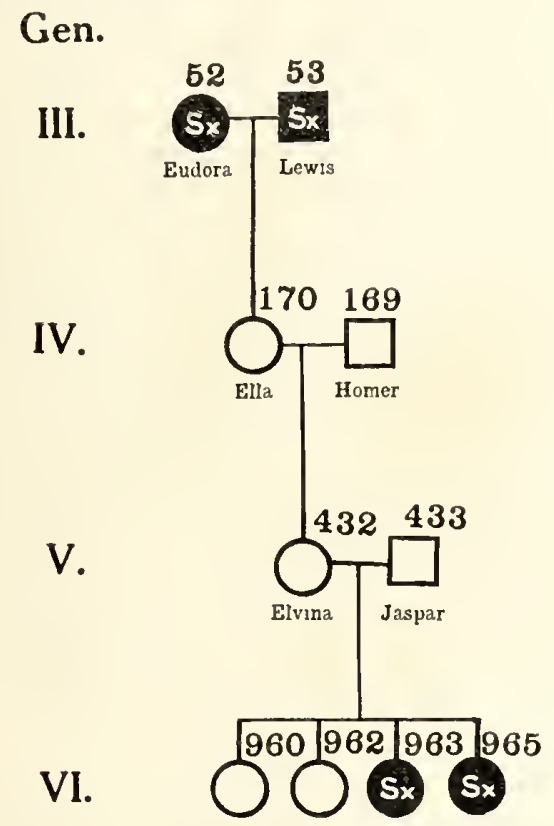

Chart 16.-Group of Jukes showing occurrence of sex offense. $\mathrm{Sx}$, licentious.

Case L.- In this case (chart 17) we start with a fir'stcousin mating between a licentious man and a young girl who had been a harlot. They had nine children, two dying in infancy. The first daughter married at 17 and had two girls, who are now both chaste. The first boy married, but had no children. The second girl was a harlot before she married, at 17 , her cousin, a licentious man. They have several children. The oldest is now 16 and a harlot. The second boy married at 23, and the next child, a girl, married at 20 , while the last two, a boy of 21 and a girl of 19 , are chaste and still unmarried.

\section{Gen.}

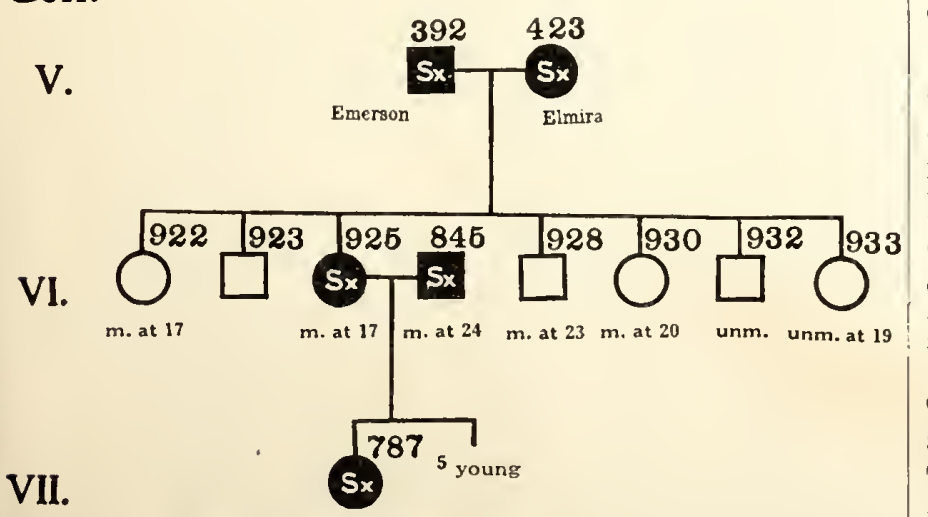

Chart 17.-Cousin-mating of two sex offenders produced here an offspring active sexually.

Sx, licentious. m. at 17 , marricd at 17 .
The low social level of these people and economic neeessities compel them to marry carly, and this early mating is hastened by the marked sexual activity which they have inherited from both sides.

Table 7 gives the amounts of chastity and licentionsness in the ehilchen, classified according to the three possibte matings of the parents: 52 chaste $\times$ chaste matings yicld 57 licentious offspring, while the 73 licentious $X$ licentious matings give 62 chaste offspring. These figures, then, will not support either the hypothesis that licentiousness or that chastity, as now diagrosed, is a mit character which, when mated to itself, will produce only that character. The Mendelian law says that a recessive character mated to a recessive character gives 100 per cent recessive in the offspring. In neither the $\mathrm{C} \times \mathrm{C}$ nor $\mathrm{L} \times \mathrm{L}$ matings in the Jukes is the expected 100 per cent reached.

\begin{tabular}{|c|c|c|c|c|c|}
\hline \multirow[b]{2}{*}{ Parents. } & \multirow{2}{*}{$\begin{array}{c}\text { No. } \\
\text { of } \\
\text { ninat- } \\
\text { ingrs. }\end{array}$} & \multicolumn{4}{|c|}{ Offspring. } \\
\hline & & Chaste. & $\begin{array}{l}\text { Licen- } \\
\text { tious. }\end{array}$ & $\begin{array}{c}\text { Unil- } \\
\text { known. }\end{array}$ & $\begin{array}{l}\text { Percentage } \\
\text { of ehaste } \\
\text { to total. }\end{array}$ \\
\hline Both parents chaste..... & 52 & 177 & 57 & 5 & 74.1 \\
\hline $\begin{array}{l}\text { Onc parent chaste, one li- } \\
\text { centious. . }\end{array}$ & 44 & 91 & $\varsigma_{6}$ & 13 & 479 \\
\hline Both parents licentious.. & 73 & 62 & $206 i$ & 13 & 22.1 \\
\hline
\end{tabular}

It is impossible for a ficld worker to make a complete study of the vita sexualis of an individual with the present sources of information, tests, and clata at hand. Many of the Jukes have exhibited certain abnormal or anti-social sexual manifestations at one time and not at another. Several of the Jukes were very immoral when young girls and as they grew older and married were faithful to their husbands and so must now be considered as social. Many female Jukes, from strains in which licentiousness was very marked, married at 13 and at 14, at the time when sex first developed strongly, had children, and have shown no obvious anti-social behavior. It is safe to say that these same Jukes would have been prostitutes in the ten years following adolescence if their marriages had been delayed until they reached the age of 25 . On the other hand, some Jukes have apparently shown no hypereroticism at any time during their lives.

The environment of harlotry and of prostitution must affect a child growing in its midst. This child may become a harlot. This does not mean that the child has a determiner for or a trait of hypereroticism. The career of harlotry once commenced may be continued as the ordinary course of behavior or for commercial reasons. The study of the Jukes, and especially the cases cited above, has persuaded me that in many cases licentiousness has an hereditary factor; while in many other cases harlotry is due less to an inability to inhibit sex impulses than to the absence of a prohibitive mores; harlotry is not "tabu." The home life of the child, the first stimulation and manifestations of sex, the first sexual experiences, the moral and ethical teaching-it is necessary to have all these data about each individual charted before drawing defi- 
nite conclusions as to the significance of the sexual reactions of that individual. And these intimate facts are very difficult for the investigator to secure.

\section{Pauperism.}

In 1874 Dugdale recorded 148 Jukes and 58 of " $\mathrm{X}$ " blood who received pauper relief either in their own homes or in almshouses. The cost of this poor relief from 1800 to 1875 was $\$ 20,680$. Many of the poormaster's books were missing in Dugdale's time; in fact, only one-third of the poor records of that period were available to Dugdale for study. Since 1875 , as before, each poor-master has kept his own records and these are very incomplete. At the end of the poor-master's term of office the record was either purposely destroyed or often thrown away as valueless. I have been unable, therefore, to make complete research into the amount of outdoor relief given to the Jukes in their homes during the past 40 years. The amount of almshouse care is taken from official records. When poor relief is noted in the description, the data come from official records or the memory of poor-masters or other reliable persons. The statistical summary gives 129 Jukes and 48 of " $\mathrm{X}$ " blood receiving poor relief to the extent of 815 years, and 170 Jukes and 19 of " $\mathrm{X}$ " blood receiving almshouse care to the extent of 495 years. Dugdale estimated the cost of poor relief to 1875 at $\$ 20,680$. As outdoor relief now averages $\$ 30$ a year per recipient in the Juke region, and almshouse or institutional care (for children) will average $\$ 150$ per year, the total cost of the poor relief since that time is estimated at $\$ 2,430$ for out-door relief and $\$ 60,600$ in almshouse care, making a total of $\$ 83,710$ of public money disbursed for poor relief.

The amount of institutional care, classified according to generation, since generation $\mathrm{V}$, when Dugdale stopped, is given in table 8 . Institutional care is classified among almshouses, Children's Homes, or House of Refuge commitments. Previous to 1875 there were no special institutions for children, and as these have developed there has been less almshouse care of them and more intelligent and far-sighted care in children's and other institutions. There is an apparent decrease in the amount of institutional care given the Jukes, but it must be noted that generations VII and VIII are in part still reproducing and others may be born into them who will receive institutional care.

It is self-evident that the receiving of poorhouse and outcloor relief is an evidence of weakness. The cause of this weakness may be varied. In many cases it is the illness of one or the other wage-earner, or the physiologic stress of childbirth in women. Other causes are inefficiency and ignorance (unemployableness). The former may be inherited or may be acquired by disease. The question of the inheritance of industry will be discussed

TABLE 8.-Institutional care subsequent to generation $V$, compared with almshouse care previously.

\begin{tabular}{|c|c|c|c|c|c|c|c|c|c|c|}
\hline & \multicolumn{2}{|c|}{ Almshouse. } & \multicolumn{2}{|c|}{$\begin{array}{l}\text { Institutions } \\
\text { for ehildren, } \\
\text { and House } \\
\text { of Refuge. }\end{array}$} & \multirow[b]{2}{*}{$\begin{array}{l}\text { Total } \\
\text { in } \\
\text { group. }\end{array}$} & \multirow{2}{*}{$\begin{array}{l}\text { Percent- } \\
\text { age of } \\
\text { institu- } \\
\text { tional } \\
\text { care for } \\
\text { ehildren. }\end{array}$} & \multirow{2}{*}{$\begin{array}{l}\text { Pereent- } \\
\text { age of } \\
\text { total } \\
\text { institu- } \\
\text { tional } \\
\text { eare. }\end{array}$} & \multicolumn{3}{|c|}{$\begin{array}{l}\text { Almshouse relief first } \\
\text { five generations. }\end{array}$} \\
\hline & $\begin{array}{c}\text { No. of } \\
\text { people. }\end{array}$ & $\begin{array}{l}\text { No. of } \\
\text { years. }\end{array}$ & $\begin{array}{l}\text { No. of } \\
\text { people. }\end{array}$ & $\begin{array}{l}\text { No. of } \\
\text { years. }\end{array}$ & & & & $\begin{array}{l}\text { Alms- } \\
\text { house } \\
\text { relief, } \\
\text { No. of } \\
\text { people. }\end{array}$ & $\begin{array}{c}\text { Total } \\
\text { num- } \\
\text { ber. }\end{array}$ & $\begin{array}{l}\text { Pereent- } \\
\text { age of } \\
\text { number } \\
\text { receiving } \\
\text { almshouse } \\
\text { relief to } \\
\text { total. }\end{array}$ \\
\hline 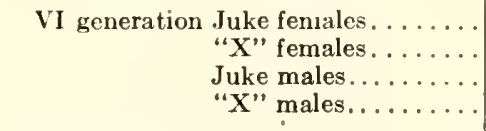 & $\begin{array}{r}10 \\
2 \\
9 \\
3\end{array}$ & $\begin{array}{r}16 \\
3 \\
14 \\
1\end{array}$ & $\begin{array}{r}24 \\
2 \ddot{5} \\
1\end{array}$ & $\begin{array}{r}82 \\
6 \dot{6} \\
3\end{array}$ & $\begin{array}{l}331 \\
137 \\
349 \\
193\end{array}$ & $\begin{array}{r}7.25 \\
7.16 \\
.52\end{array}$ & $\begin{array}{r}10.27 \\
1.46 \\
9.74 \\
2.07\end{array}$ & $\begin{array}{l}\cdots \\
\cdots \\
\cdots \\
\cdots\end{array}$ & $\begin{array}{l}\cdots \\
\cdots \\
\cdots \\
\cdots\end{array}$ & $\begin{array}{l}\ldots \ldots \\
\ldots \ldots \\
\ldots \ldots \\
\ldots \ldots\end{array}$ \\
\hline $\begin{array}{r}\text { VII generation Juke females. . . . . . } \\
\text { "X" females. . . . . . } \\
\text { Juke males. . } \mathrm{X} \text { " males. . . . . . }\end{array}$ & $\begin{array}{c}3 \\
\cdots \\
2 \\
\cdots\end{array}$ & $\begin{array}{l}17 \\
2 \\
2 \\
\cdots\end{array}$ & $\begin{array}{l}23 \\
13 \\
\cdots\end{array}$ & $\begin{array}{l}48 \\
29 \\
\cdots\end{array}$ & $\begin{array}{r}389 \\
30 \\
336 \\
66\end{array}$ & $\begin{array}{l}5.91 \\
3.97 \\
3 .\end{array}$ & $\begin{array}{l}6.69 \\
4.46 \\
\cdots\end{array}$ & $\begin{array}{l}\cdots \\
\cdots \\
\cdots\end{array}$ & $\begin{array}{l}\cdots \\
\cdots \\
\cdots \\
\cdots\end{array}$ & $\begin{array}{l}\ldots \\
\ldots \\
\ldots \ldots \\
\ldots\end{array}$ \\
\hline 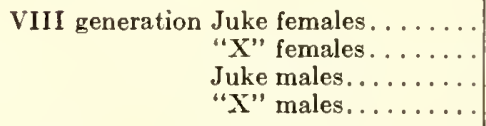 & $\begin{array}{l}1 \\
\cdots \\
\cdots \\
\cdots\end{array}$ & $\begin{array}{l}1 \\
\cdots \\
\cdots \\
\cdots\end{array}$ & $\begin{array}{l}3 \\
\ldots \\
1\end{array}$ & $\begin{array}{c}4 \\
\cdots \\
1\end{array}$ & $\begin{array}{r}62 \\
2 \\
69 \\
6\end{array}$ & $\begin{array}{l}4.83 \\
\ldots 45 \\
\ldots\end{array}$ & $\begin{array}{l}6.44 \\
1.45 \\
\cdots\end{array}$ & $\begin{array}{l}\cdots \\
\cdots \\
\cdots\end{array}$ & $\begin{array}{l}\ldots \\
\ldots \\
\ldots \\
\cdots\end{array}$ & $\begin{array}{l}\ldots \ldots \\
\ldots \ldots \\
\ldots \ldots \\
\ldots \ldots\end{array}$ \\
\hline $\begin{array}{r}\text { IX generation Juke females. . . . . . . } \\
\text { Juke males....... }\end{array}$ & $\begin{array}{c}1 \\
\cdots\end{array}$ & $\begin{array}{c}1 \\
\cdots\end{array}$ & $\ddot{*}$ & $\cdots$ & $\begin{array}{l}2 \\
\cdots\end{array}$ & $\begin{array}{l}\cdots \\
\cdots\end{array}$ & $\begin{array}{c}50.00 \\
\ldots\end{array}$ & $\cdots$ & $\begin{array}{l}\cdots \\
\cdots\end{array}$ & $\begin{array}{l}\cdots \\
\cdots\end{array}$ \\
\hline 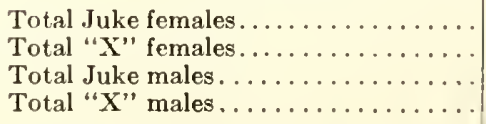 & $\begin{array}{r}15 \\
2 \\
11 \\
3\end{array}$ & $\begin{array}{r}35 \\
3 \\
16 \\
1\end{array}$ & $\begin{array}{r}50 \\
\ddot{39} \\
1\end{array}$ & $\begin{array}{r}134 \\
9 \dot{8} \\
3\end{array}$ & $\begin{array}{l}993 \\
305 \\
950 \\
420\end{array}$ & $\begin{array}{r}5.03 \\
.65 \\
4.01 \\
.24\end{array}$ & $\begin{array}{r}6.54 \\
.65 \\
5.26 \\
.95\end{array}$ & $\begin{array}{r}29 \\
5 \\
26 \\
8\end{array}$ & $\begin{array}{l}209 \\
136 \\
200 \\
150\end{array}$ & $\begin{array}{r}13.87 \\
3.67 \\
13.00 \\
5.33\end{array}$ \\
\hline $\begin{array}{l}\text { Total Juke } \ldots \ldots \ldots \ldots \ldots \ldots \ldots \ldots \ldots \ldots \ldots \\
\text { Total "X" } \ldots \ldots \ldots \ldots \ldots \ldots \ldots \ldots\end{array}$ & $\begin{array}{r}26 \\
5\end{array}$ & $\begin{array}{r}51 \\
4\end{array}$ & $\begin{array}{r}89 \\
1\end{array}$ & $\begin{array}{r}232 \\
3\end{array}$ & $\begin{array}{r}2,094 \\
726\end{array}$ & $\begin{array}{r}4.20 \\
.14\end{array}$ & $\begin{array}{r}5.49 \\
.83\end{array}$ & $\begin{array}{l}55 \\
13\end{array}$ & $\begin{array}{l}409 \\
286\end{array}$ & $\begin{array}{r}13.45 \\
4.54\end{array}$ \\
\hline 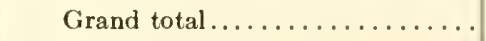 & 31 & 55 & 90 & 235 & 2,820 & 3.19 & 4.29 & 68 & 706 & 9.63 \\
\hline
\end{tabular}




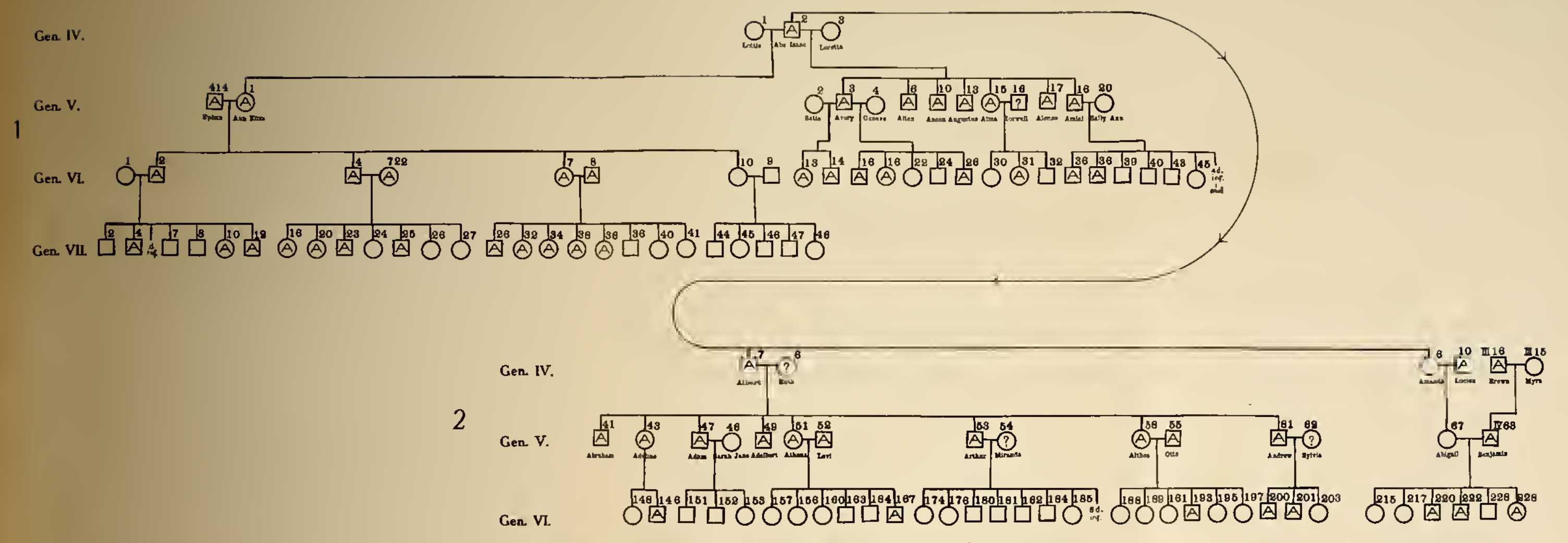

Crart 18. Group of Descendants of Ada's Illcgitimate Child, showing occurrence of Intemperance. 
later. The other factors need not be taken up in this report. For many years the granting of poor aid was used quite freely to advance the aims of politicians. In later years there has been much less poor relief given, since now the tenure of office of the poor-master depends on his ability to combine econony with efficiency. The improved care in Children's Homes over that in alınshouses is an indication of a better attempt on the part of society to take care of its defectives and delinquents, and means nothing as to increase or lecrease of pauperism or weakness.

Dugdale discussed many cases of pauperism in which syphilis and clisease were the primary causes. The subsequent behavior of these cases will not be discussed in this paper, as they properly belong to the field of public health. Any one interested in this question can follow it by referring to the individuals in the general description and tracing their descendants.

\section{Syphilis.}

Dugdale was aided in his investigation of the Jukes by a physician of note, who was 84 years of age at that time, and who had been the sole doctor for years in the three counties in which the Jukes lived. He went in among them frequently and because of his intimate knowledge of their individuality it was possible for him to aid Dugdale to determine with great precision the amount of syphilis and other disease prevalent, and in many cases to trace its source. With the dispersal of the Jukes into new environment and the attendance of a different physician at each needed time, it has been impossible to secure accurate information or, in fact, any adequate idea of the present amount of syphilis and kindred diseases in the family. From our records there is apparently not as much syphilis now as formerly, but this is due largely to lack of data.

\section{INTEMPERANCE.}

The Jukes have no distinctive or characteristic groups of alcoholics, such as characterized the Nams. Of the Jukes, 181, and of " $\mathrm{X}$ " blood 101, are classed as intemperate, and the occasional drunkard, as well as the steady drinkers, are included in this total. These are scattered through the whole Juke family, but most of them will be found on charts 1 and 6 . Chart 18 shows the alcoholic group of Ada's illegitimate descendants. The tabulation of the different matings on this chart, where both parents are known, is given in table 9 , from which it would appear that where both parents are alcoholic, both temperate and intemperate children will be produced. However, the proportions are not significant, as some of the "temper-

TABLE 9.

\begin{tabular}{|c|c|c|c|c|}
\hline & $\begin{array}{c}\text { No. } \\
\text { of } \\
\text { mat- } \\
\text { ings. }\end{array}$ & \multicolumn{3}{|c|}{ No. of off prenting. } \\
\cline { 2 - 5 } & Alcoholic. & Temperate. & Unknown. \\
\hline Both parents alcoholic..... & 5 & 15 & 16 & $\ldots$ \\
One parent alcoholic, one & & 13 & 9 & 2 \\
temperate............. & 5 & 0 & 5 & $\ldots$ \\
\hline
\end{tabular}

ate" are still young. The one mating where both parents are temperate produced 5 temperate children.

The descendants of Alexander and Beatrice in the fourth, fifth, and part of the sixth generation were in general intemperate. They lived in a community where there were many rum shops, and one of them, Albert, IV 7, kept a tavern and brothel himself. The habits of many of the consorts of these Jukes are unfortunately unknown and therefore an analysis of the matings from the Mendelian standpoint can not be made. The crime group in Ada's illegitimate descendants, chart 1 , were all intemperate and these are slown in chart 18 . Here alcoholism is found in three generations and in part of the fourth. When the Jukes dispersed into better localities many temperate persons were the result.

\section{Crime.}

There are 118 criminals of Jukc blood and 53 of " $\mathrm{X}$ " blood in the Juke study. The amount of crime in the Jukes has not increased relatively as fast as the population and there arc not as many vicious criminals to-day as at the time when Dugdale studied them. The marked criminality in Dugdale's time, which led to his study of this family and which has characterized the Jukes as distinctive from other families, is now no longer found. 'The dispersal of the family in 1880 has prevented the congregate stealing and so the crimes which are now committed are more often the product of a single brain than formerly and not so daring. The illegitimate group of Ada's descendants are to-day more criminal than the rest of the family, yet even among these, many families of law-abiding citizens may be found.

The criminal illegitimate posterity of Ada is shown in chart 19, which is marked witl respect to crime. The few criminals in Delia's and Effie's descendants are shown in chart 20 and chart 21 . They have been classified into criminals - those who have been convicted of crime (C); criminalistic, those who are criminal by nature or have committed criminal acts and have never been caught $\left(\mathrm{C}^{\prime}\right)$; and self-controlled, or law-abiding citizens $(\mathrm{H})$. In order to study the correlation between sex offense and crime, all sex offenders are indicated on the charts by "Sx". Dugdale regarded prostitution in the female as the analogue of crime in the male.

The offspring are classified according to the mating of the parents in table 10 . Six matings of criminal $\times$ criminal produce 58 per cent criminals, 16 per cent sex offenders, 6 per cent criminalistic, while 19 per cent are self-controlled.

Table 11 gives statistics showing in one group the dishonest and sex offenders classed as criminals; in the other group the criminals and dishonest are classed together as criminals and the sex offenders are classed with the honest.

If criminality is a recessive trait, a $\mathrm{C} \times \mathrm{C}$ mating should produce 100 per cent criminal offspring. If self-control is recessive, then an $\mathrm{H} \times \mathrm{H}$ mating should give 100 per cent honest offspring. The two groupings above show that neither the $\mathrm{C} \times \mathrm{C}$ nor $\mathrm{H} \times \mathrm{H}$ matings give 100 per cent of that trait in the offspring, irrespective of whether the sex 
offenders are classed with the criminal or the controlled. There is, indeed, no good reason for regarding criminality as a unit biological trait.

TABLE 10.-Tabulation of matings and offspring with relation to crime.

\begin{tabular}{|c|c|c|c|c|c|c|c|c|c|c|}
\hline \multirow[t]{2}{*}{ Parents. } & \multirow{2}{*}{$\begin{array}{l}\text { No. } \\
\text { of } \\
\text { mat- } \\
\text { ings. }\end{array}$} & \multicolumn{3}{|c|}{ Offspring. } & \multirow{2}{*}{$\begin{array}{l}\text { Total } \\
\text { C, Sx, } \\
C^{\prime} .\end{array}$} & & \multirow{2}{*}{$\begin{array}{l}\text { Per- } \\
\text { eent- } \\
\text { age of } \\
\text { anti- } \\
\text { social. }\end{array}$} & \multirow{2}{*}{$\begin{array}{c}\text { Per- } \\
\text { cent- } \\
\text { age of } \\
\text { self- } \\
\text { con- } \\
\text { trolled. }\end{array}$} & \multicolumn{2}{|c|}{$\begin{array}{l}\text { If } \mathrm{C} \text { is reccssive } \\
\text { and } \mathrm{H} \text { is domi- } \\
\text { nant, expeeted } \\
\text { percentages. }\end{array}$} \\
\hline & & c. & Sx. C & $C^{\prime}$. & & & & & Not $\mathrm{H}$. & H. \\
\hline $\mathrm{C} \times \mathrm{C}$. & 6 & 18 & 5 & 2 & 25 & 6 & $\ldots$ & . & $\ldots$ & . \\
\hline $\mathrm{C} \times \mathrm{C}^{\prime}$. & 1 & 1 & & 2 & 3 & 2 & $\ldots$ & $\ldots$ & $\cdots$ & $\ldots$ \\
\hline$C \times S x \ldots$ & 22 & 23 & 32 & 9 & 64 & 20 & $\ldots$ & $\ldots$ & $\ldots$ & $\ldots$ \\
\hline $\mathrm{Sx} \times \mathrm{Sx} \ldots$ & 3 & 2 & 2 & 2 & 6 & 3 & $\ldots$ & $\ldots$ & $\ldots$ & $\cdots$ \\
\hline $\mathrm{Sx} \times \mathrm{C}^{\prime}$. & 5 & 9 & 1 & 1 & 11 & 1 & $\ldots$ & $\ldots$ & $\cdots$ & $\cdots$ \\
\hline $\begin{array}{l}\text { Total anti- } \\
\text { social mat- } \\
\text { ings...... }\end{array}$ & 37 & 53 & 40 & 16 & 109 & 32 & 77.3 & 22.7 & 100 & 00 \\
\hline $\mathrm{H} \times \mathrm{C}$. & 6 & 6 & 7 & 3 & 16 & 11 & $\cdots$ & & $\cdots$ & . \\
\hline $\mathrm{H} \times \mathrm{Sx}$. & 7 & 4 & 6 & 2 & 12 & 16 & $\ldots$ & $\cdots$ & $\cdots$ & . \\
\hline $\begin{array}{c}\text { Total mixed } \\
\text { matings.... }\end{array}$ & 13 & 10 & 13 & 5 & 28 & 27 & 50.9 & 49.1 & & \\
\hline $\mathrm{H} \times \mathbf{H} \ldots$ & 12 & 6 & 3 & 1 & 10 & 42 & 19.2 & 80.8 & 00 & 100 \\
\hline
\end{tabular}

TABLE 11.

\begin{tabular}{|c|c|c|c|c|}
\hline \multirow{2}{*}{ Parents. } & \multicolumn{2}{|c|}{ Off spring. } & \multirow{2}{*}{$\begin{array}{l}\text { Per- } \\
\text { cent- } \\
\text { age of } \\
\text { crimi- } \\
\text { nal. }\end{array}$} & \multirow{2}{*}{$\begin{array}{l}\text { Per- } \\
\text { eent- } \\
\text { age of } \\
\text { self- } \\
\text { eon- } \\
\text { trolled }\end{array}$} \\
\hline & $\begin{array}{l}\text { Crimi- } \\
\text { nal. }\end{array}$ & $\begin{array}{c}\text { Self- } \\
\text { con- } \\
\text { trolled. }\end{array}$ & & \\
\hline \multicolumn{5}{|l|}{$\begin{array}{l}\text { Dishonest and sex offenders classed as } \\
\text { criminal: }\end{array}$} \\
\hline Both parents eriminal............ & 109 & 32 & 77 & 23 \\
\hline $\begin{array}{l}\text { Une parent ellminal, the other } \\
\text { self-eontrolled, "honest". ..... }\end{array}$ & 28 & 27 & 51 & 49 \\
\hline Both parents sclf-controlled...... & 10 & 42 & 19 & 81 \\
\hline $\begin{array}{l}\text { Criminals and dishonest elassed to- } \\
\text { gether as eriminal; sex offenders } \\
\text { classed with the honest: }\end{array}$ & & & & \\
\hline Both parents criminal.......... & 23 & 13 & 63.9 & 36.1 \\
\hline $\begin{array}{l}\text { One parent criminal, the other } \\
\text { self-eontrolled. "honest". . . . }\end{array}$ & 51 & 72 & 41.5 & 58.5 \\
\hline Both parents self-eontrolled...... & 17 & 72 & 19.1 & 80.9 \\
\hline
\end{tabular}

Dugdale's cases will now be discussed in the light of events of the past 40 years.

CASE Q (case 25 of Dugdale). - This is the case of a boy of 17 , VI16 (see chart 19), who was arrested and sent to the penitentiary for petit larceny. His father, Avery, had been twice in the county jail for assault and battery and was then serving a 5 -year State prison sentence for rape on his niece in her twelf th year. The environment was one where the people had recourse to foraging excursions during which they stole food, clothes, and wood. When the father was sent to State prison, the mother went to the poorhouse with her children, while VI 16 roamed at large and was at this time arrested.

Again, at the age of 24 years, he was in the penitentiary for 3 months for petit larceny, at 29 he was sent to State prison for $2 \frac{1}{3}$ years for assault in the third degree. Since that time he has been arrested several times for drunkenness. He is feeble-minded, ignorant, inefficient, is a beggar, and lives in deserted houses or in hovels. He is married, but has no children.

His sister, VI 19, was licentious and was convicted twice for using indecent language on the public streets, and once for intoxication. She was not considered weakminded, but was weak-willed and had a low standard of morals and behavior. By her first husband she had one son, who was placed in a good home in the Middle West. Here he attempted to set fire to a straw stack. At one time he stabbed a schoolmate with a knife after having been taunted by him. The boy, now 12 years of age, is unmanageable and is not mentally bright. By a criminal man this same woman had a daughter (a half sister of the boy just mentioned). This girl, too, was removed to the Middle West and was troublesome and hard to control. She died at the age of 8 years.

A brother and sister of VI 16 could not be traced by the investigator.

A brother, VI 26, was arrested when 23 years old for robbery and sent to State prison. This boy was born and grew up after the father's career of crime had ended, but his older brother had committed crime while he was adolescent. He, too, is feeble-minded.

Both the heredity and the environment lead to crime in this fraternity.

CASE R (case 26 of Dugdale; see chart 19).-VI 2 and VI 4 pushed a boy over a cliff 40 feet high out of malicious mischief. The home of the two was one of idleness, intemperance, and debauchery. These two boys had one brother who was sent to the House of Refuge at 14, for assault and battery on his father, and died there. Two sisters were sent, at 14 and 11 years, respectively, to the House of Refuge as disorderly children. The older was immoral; both were vagrants, as their mother had just been sent to the penitentiary for an assault on their father.

These five brothers and sisters were criminal only as described above. The descendants of four of them were immoral in general and the following were criminal: VII 4, who was sentenced for assault while drunk and intoxication; VII 19, 20, and 24, convicted of prostitution; VII 29 arrested for non-support of his wife; VII 34 arrested for prostitution and theft, guilty, though not convicted; and VII 38, who was sent at 14 to a reformatory for prostitution. The environment of these, as with generation VI, was one of poverty, licentiousness, and intemperance. All of these lived in or near $Z$, not far from the Juke ancestral area. On going back to generation $\mathrm{V}$ of this group, thieves and robbers are found frequently. In generation VI crimes turn to assault in the males and prostitution in the females, and in generation VII the crimes for the men are assault while intoxicated and non-support, and for the women prostitution with its attendant stealing from the person. It will be very interesting to follow the career of 3 daughters of VII 19, a criminal prostitute, 2 of whom are in good noral homes in the Middle West, while the third is with her grandmother, VI 722, in her Juke hovel home.

Case S.-Abraham, V 41, is discussed by Dugdale in case 27 . There is no further criminal career of him known, and he had no descendants. 


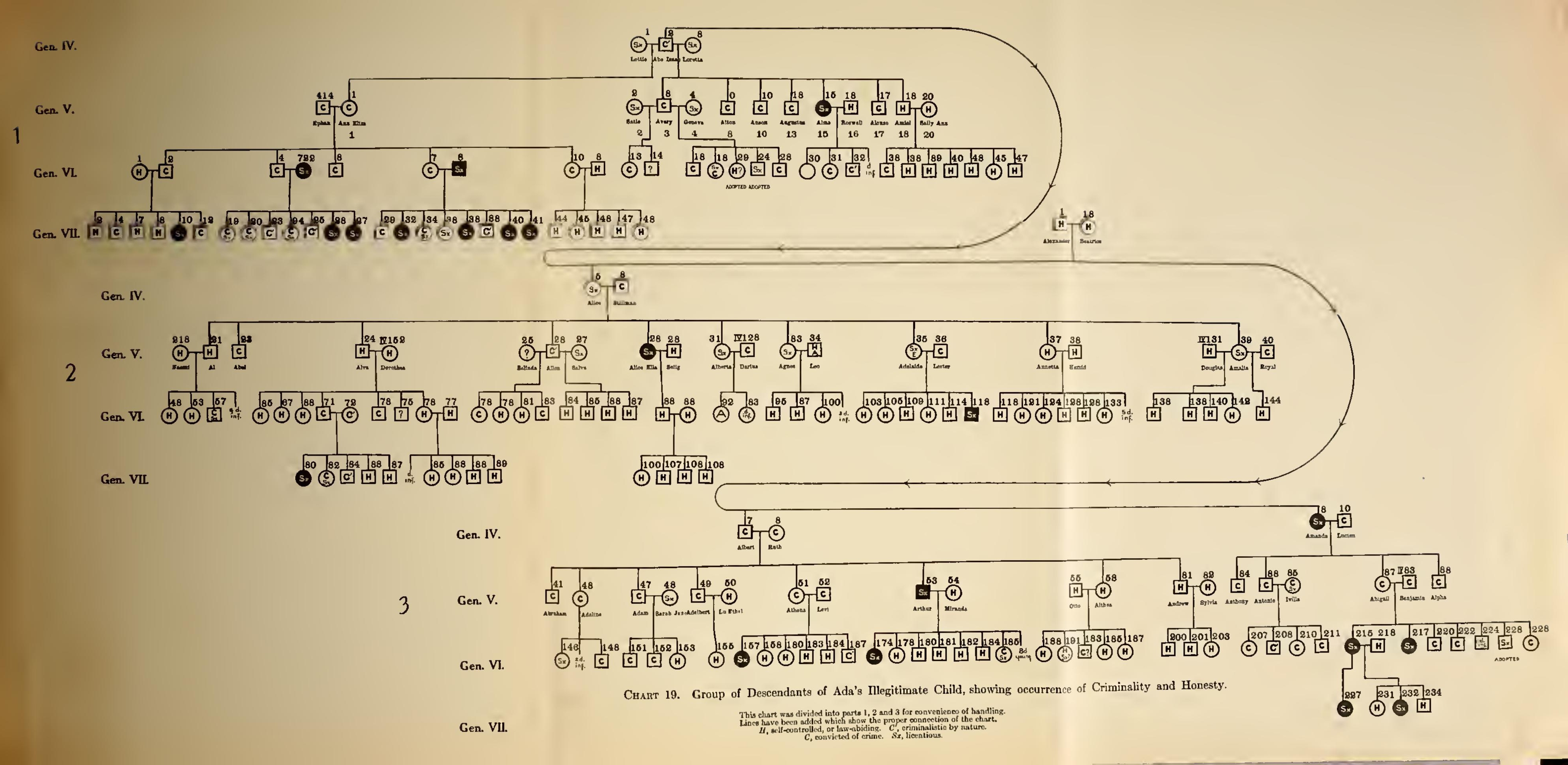



CASE 'T (case 28 of Dugdale, see chart 19).-In generation $V$, chart 1 , are found Anthony, Abigail, and Antonio (V 64-67), brothers and sister, whose father was a thief and whose mother was a harlot and a granddaughter of Ada. Anthony, the oldest, committed a number of offenses, among them a murder, but he escaped punishment for this. The second, Abigail, became a contriver of a crime which Antonio carried into effect and for which he received 20 years of imprisonment. Dugdale says that in this case the boldest and most intelligent was the oldest child. These three had a younger brother, Alpha, who at 17 was sent to the penitentiary for $2 \frac{1}{3}$ years for burglary. He died at 19.

Anthony and Alpha had no descendants.

Abigail married her cousin Benjamin, who thieved with his wife and was arrested for burglary but not convicted. They had seven children: a feeble-minded prostitute, never arrested; a feeble-minded prostitute, forced to thieve by her mother and, at 17 years of age, sent to the House of Refuge; a feeble-minded male, at the age of 15 sent to the House of Refuge, at 18 convicted of disorderly conduct and assault and battery, at 19 of stealing, at 20 of assault and battery, at 26 of assault, and at 37 of assault and battery; a feeble-minded male, at 13 sent to the House of Refuge, later convicted five times of petit larceny, assault, and intemperance; a male, placed in Children's Institution and now dead; a male, adopted into a family in the Middle West, now ignorant and semiindustrious, with low morals, not criminal but feebleminded; and a female who has been arrested many times for disorderly conduct, prostitution, intoxication, and running a disorderly house.

Antonio, who had served terms in the penitentiary for rape and who had spent 23 years in State prisons for burglary, married a harlot who had been arrested for disorderly conduct; they had four children.

The first was raped at 11 years by a "stepfather" and was then sent to the House of Refuge. At 13 and at 24 years, respectively, she was sent to the penitentiary for prostitution, and finally died in a bawdy house.

The second, a male, was sent at 10 years to the House of Refuge as a vagrant and again at 16 to the same institution as "ungovernable and troublesome." He was never arrested for crime, but is mentally below the average.

A third was sent to the House of Refuge at 8 years as a disorderly child. At 16 , at 18 , and again at 19 , she was sent to the penitentialy for prostitution. She was fceble-minded and died at 29 years.

The last child, a male, was sent to the House of Refuge at 10 years for petit larceny and disorderly conduct. At 22 he was sent to State prison for a year for burglary and at 23 to the penitentiary for 6 months for obstructing an officer. Another term in penitentiary for stealing ended his criminal career and since this he has reformed, but is feeble-minded and considered " a half sort of a man."

The environment in this case was as follows: When Antonio was sent to State prison for twenty years for burglary, the mother of his four children cohabited with a vicious man in a hovel in the hills, who committed rape on the oldest child and forced the others to petty thieving until all the children were sent to the House of Refuge. After the children returned from the House of Refuge, they found their mother living with still another man, her third consort, and they then became vagrants, finding a home where they could, usually in hovels or brothels.
The subsequent history of Dugdale's case 32 is discussed in case Q.

CAse U (case 33 of Dugdale, see chari 19).-Alton, $\mathrm{V} 6$, was a boatman at 22 , and in company with his brother-in-law committed a burglary and served a term of 3 years in State prison. After discharge from prison, at the age of 25 years, he became a laborer and acquired 10 acres of land. He cohabited with three different women, but left no descendants. His first State prison term may have exerted a bencficial influence on his behavior, for he committed no more crime. His moral tone does not seem to have been changed greatly.

Case V (case 34 of Dugdale, see chart 19).-Alton's brother, Anson, V 10, began his career with petty crime at 12 years, and continued until the age of 36 . Dugdale says: "Whether he reforms is to be tested, but the probabilities are against it, as he is living with a licentious woman." From 1874 there is no record of a crime by him. He was only semi-industrious and was intemperate.

He never acquired any property and after his first consort died he cohabited with her sister, by whom he had two children. That Alton lacked domesticity and sense of responsibility for his family is indicated by the fact that his two children were so neglected that they had to be removed by the public and sent to a Children's Home to be given proper care. There is now no trace of these children.

Case W (case 35 of Dugdale, see chart 19).-In the discussion of crime and the relation of heredity to it, special attention is called to the case of Adam, V 47, and his three children, two of whom became criminals, while the other was strictly honest. Dugdale, page 53, states: "[Adam] we find at 12 assisting his brother in a burglary; at 17 serves two years in State prison for burglary; at 22 two more years for breach of peace, no doubt the severity of the sentence being made to cover two indictments for burglary which could not be proved, but which he no doubt committed; at 24 , burglary, third degree, Sing Sing three years. It is said that the total years of imprisonment he has served in Pennsylvania, New Jersey, Vermont, and Rhode Island, has been from 13 to 14 years. In Clinton prison he learned iron-rolling and also industrious habits, for now he has moved to another county, rents a quarry, and employs men to get out flagstone. Here, again, bcfore the meridian of life is past, the education of labor, together with the experience of a riper age, produce an amended career." So far Dugdale.

At 54 Adam was in State prison for 3 years for burglary; at 66 he was in State prison for larceny, and again at 69 he was in State prison. The following story is told of him and vouched for by a former county judge of $Z$ county. Adam and another had committed a burglary. Suspicion turned toward the other. A reward was offered by the sheriff for his capture. Adam alone knew of his friend's whereabouts. He brought this man to the jail, collected the reward, and turned it over to a lawyer, who defended his friend and secured his release. Adam died in the poorhouse at the age of 88. His last consort was Sarah Jane. She was industrious and neat, but deserted Adam in order to cohabit with another when her youngest child, a girl, was 13 . She is now living with this last man, is semi-refined, and is a church-going woinan. Adam and Sarah Jane lived in the Juke region for some years and when the children were still young 
they moved to another State to escape the consequences of a crime. The oldest child, a boy, VI 151, was considered below the average of his class in school work. He was arrested at 11 for stealing and sent to a reformatory. Here he is recalled by the teachers as being "very stupid and below grade mentally." He instigated an imbecile boy to set fire to the institution buildings, hoping thereby to escape during the excitement which would follow the discovery of the fire. The fire was soon extinguished and the perpetrators caught. The Juke boy was sent to State prison for arson for a term of 4 to 7 years. He died in prison of tuberculosis.

His brother, VI 152, 4 years younger, was sent to the truant school at 10 , and to a reformatory at 11 for incorrigibility, and at the latter he found his older brother, who had preceded him. He was recalled by his teachers at the institution as "feeble-minded." At 17 he was finally discharged from the reformatory. The following year he was convicted of breach of the peace and burglary. Here followed a career of burglary with subsequent incarcerations until at 22 he committed an assault with intent to kill and was sent to State prison for 10 to 15 years. Here he died.

In strong contrast to these two boys is their sister, VI 153, 2 years younger than the boy just described. This girl was keen, wide-awake, and industrious. She worked in factories, but was not affected by the low moral tone of the other employees. She retained her chastity; at 24 married a respectable man, and has one small child. It is difficult to explain by environment alone the difference in social behavior between this woman and her two brothers. The evidence indicates that the girl is normal, while the two boys were feeble-minded. The two boys are criminal perhaps as much from a combination of mental weakness and the example of their father as from any inheritance of "criminality" from him. They are criminal for the same reasons (hereditary tendencies and training) that their father was. Nothing is known of the mother's ancestors or collaterals.

Case X (case 36 of Dugdale, see chart 19).-Adelbert, $\mathrm{V} 49$, brother of Adam, was sent to the county jail at the age of 20, and again at 21 for assault and battery. At 22 he was sent to State prison for 2 years for burglary in the third degree. At 31 he moved into the same county with his older brother, purchased a farm, worked a quarry upon it, and at 37 was worth $\$ 5,000$. He was intemperate, however, and had taken part in many petty fights, and, while "considered quite a man," was, nevertheless, so anti-social in his dealings with others as to be always referred to as a "Juke."

Three cases of crime which have appeared sillce Dugdale wrote and which are interesting as showing the relation between crime and mental defect, are given in Cases $\mathrm{Y}, \mathrm{Z}$, and AA.

CASE Y (see chart 20).-Jonas, V 200, a licentious ne'er-do-well, married his first cousin, Etta, V 387, a harlot whose father was a criminal. Jonas and Etta were properly called feeble-minded. They had two sons, the first, VI 529, is an imbecile, has no causation, and is a licentious beggar who at 29 years of age broke into a store to commit burglary, was arrested, and sent to State prison for 4 years. The severity of the sentence is unaccountable. At 47 he was sent to jail for vagrancy.
At present he is a vagrant, $i . e$., wandering here and there with no visible means of support and depending on charity for his living. His brother, VI 531, has cohabited with many women. His ideas of causation are deficient and he has no moral sense. At the age of 21 he was sent to a reformatory for burglary, committed the same year as his older brother's offense. He has since had several jail sentences for petty crime. Here the crime can be directly traced to the mental defectiveness of the two individuals.

CASE Z (see chart 20).-Edgar, V 428, chart 6, was the seventh child of Elias and Flossie. Elias was an habitual drunkard and was arrested for assault and battery, but forfeited his bail. Nothing is known of the traits of Flossie. Edgar cohabited, when young, with VI 754, later married her, and had nine children, three of whom died in infancy. At the age of 36 he was sent to the penitentiary for 4 months for petit larceny. His wife became a prostitute during this period, and when he returned she refused to live with him. Edgar secured a housekeeper who likewise deserted him. He then continued his illicit relations with two of his daughters and with other young girls at his home, and was finally arrested, convicted of rape, and sent to State prison for 10 years. He died in prison. He was of very low mental grade, his causation was deficient, his inhibitions weak, and consequently he had no morals. Under the home circumstances which prevailed, immoral relations with his own daughters necessarily ensued and society was forced to deal with this man as a criminal because he lacked intelligence and insight and the inhibitions that enable one to control the sexual instincts.

Case AA.-Bill, IV 78, a coarse, intemperate laborer, is found in chart 3 . He was mentally undeveloped and had a weak moral sense. His brothers and sisters were not criminals, but two of them, Brunhilde and Bessie, had offspring who were criminal. Bill married a shrewish, ignorant woman and had many children by her. The first, Orrin, bore a good name for a Juke, married a cousin, and had, among others, one criminal son. The next three children of Bill were harlots, but not criminal otherwise. The fifth child who grew up was Willett, whose criminal history will be described in full. The next, a daughter, Bridget, was a harlot before marriage. Jerry, the next, was feeble-minded but not criminal. Harmon, the last son of Bill, committed burglary and arson at the age of 18 with his older brother Willett, then 25 years of age. The two were sent to State prison for 8 years and soon after leaving prison Harmon died. Willett, who was 25 at the time of his first crime, was considered "half-witted" as a boy and although generally pleasant became very disagreeable when crossed. At 32 he was arrested for assault and fined $\$ 5$. For 15 years after this he was industrious and reputable. At the age of 47 he became enamoured of a married woman and upon her instigation he murdered her husband, thinking that by doing so he could live with this woman, although at the same time he had a consort living. For this he paid the penalty of death. The woman was sent to State prison for life for her part in the crime. She, too, is feeble-minded, although of a much higher grade than Willett, and it was her brain which contrived and directed the crime. The criminality here is closely associated with mental defect and lack of moral restraint. 


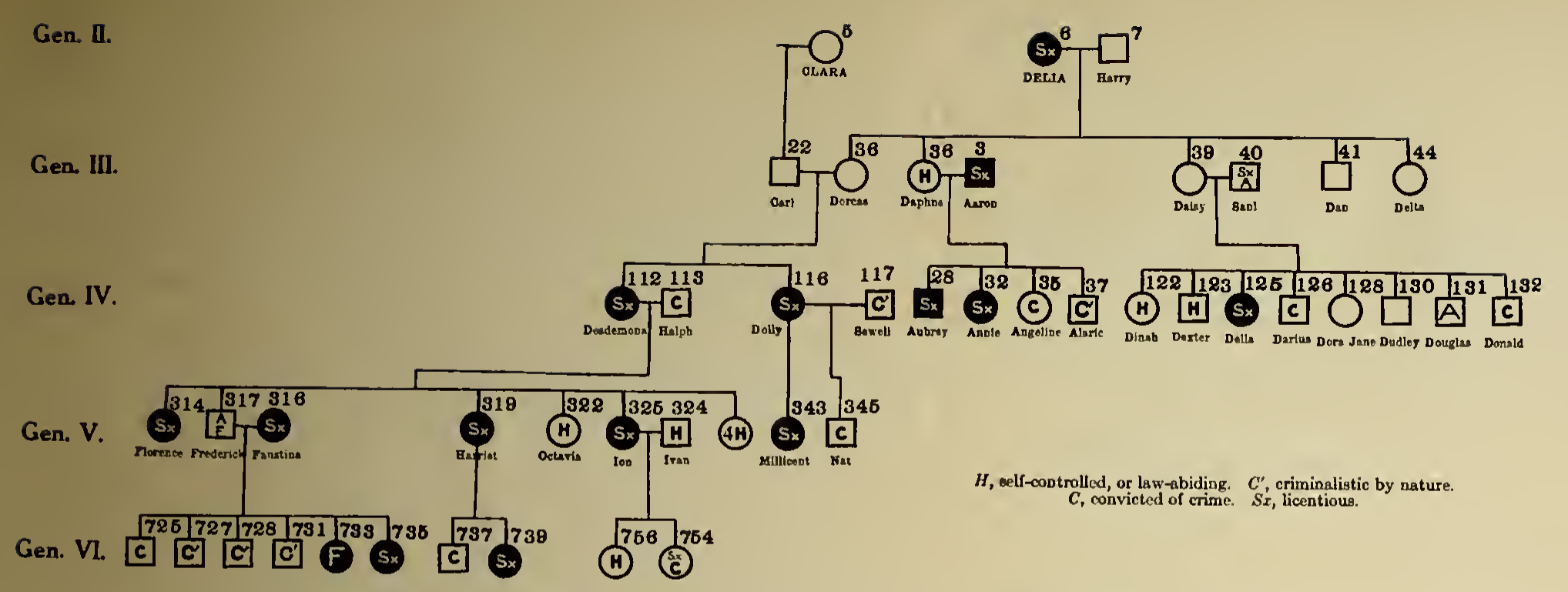

Chart 20. Group of Descendants of Delia, showing occurrence of Criminality and Honesty.

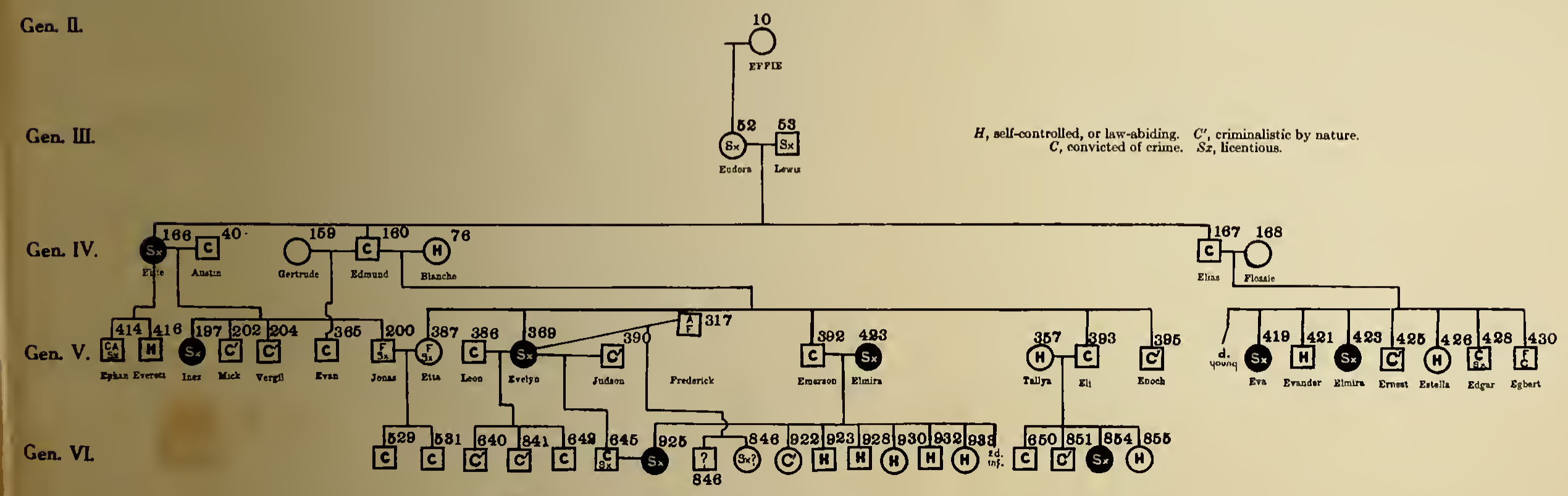

Crart 21. Group of Descendants of Effie, showing occurrence of Criminality and Honesty. 

A study of this section shows the close correlation between feeble-mindedness and crine in the Jukes. It has been the writer's good fortune to be able to study carefully many of the Juke criminals of to-day and in every case the individual has been prover without a doubt to be feeble-ninded. Willett, who committed murder; VI 529, a low-grade imbecile who committed burglary; Edgar, a rapist; and VI 16, who committed assault, are all mental defectives, and in none of these has their criminal record biased the writer in diagnosing their mentality. There is no evidence in the Jukes which points to the existence of a trait of criminality. Not all feeble-minded Jukes are criminal, but all the Juke criminals that I have known I regard as mentally defective.

\section{INDUSTRY.}

Max, the progenitor of two of the five consorts of the first Juke sisters, was described as "averse to steady toil, working hard by spurts, and idling by turns." In glancing over the individuals in generation III of the Jukes, the terms "semi-industrious," "would work well on a spurt," "industrious in youth," and "lazy" are found scattered quite promiscuously in the description. As one reads further in the story he finds, even in later generations, that many are indolent or semi-industrious. He will also find, not so often in the earlier generations as in the later ones, that there are industrious Jukes. Before discussing in detail the inheritance of industriousness, it will be interesting to recall some of the facts about the early Jukes. Some of these were farm laborers and consequently unemployed during the winter months; others worked in the cement mines, an industry which is not in operation from October until May. Most of Effie's descendants, in generation IV, left the Juke region, went a short distance away, and settled where brickmaking was the local industry. This, too, is an occupation which is necessarily suspended during the winter months. The young members of the family become accustomed to observe the intermittent labor which is forced on adults and so those who are inherently indolent use this as an apology for laziness. Their reasoning is that if one can get along by working only part of the time, there is no need of working at all. Thus the development of the trait which is present in the individual is fostered. There are, then, groups of hardworking Jukes, households where indolence prevails, and families where both traits are found.

Charts 22 to 24 show the manner of inheritance of industry and indolence. $\mathrm{L}$ is the symbol used in the charts for industry or laboriousness, and $\mathbf{S}$ for indolence, unindustriousness, or slothfulness. In chart 22 the mating of $\mathrm{L} \times \mathrm{L}$ in generation IV (Alfred and Dinah) produced five industrious individuals. One of these, Achsa, married Hendrick, industrious, with industrious parents, and had three children, all of whom were industrious. Addie, industrious, married Marvil, also industrious, and had one son who was not industrious, but this son was tubercular and also syphilitic, so his lack of industry may have been the result of his physical condition. Horace, the last of these five, was idle at the age of 19 but industrious the rest of his life. He married an industrious woman from an industrious family and had nine children, all industrious. In this chart L crossed with $L$ produces almost invariably industrious offspring.

In chart 23 we start with two matings of $\mathrm{S} \times \mathrm{S}$. One produced Alan, S; Austin, doubtful but probably S; and 7 unknown. These 7 were studied by Dugdale, who made no record of their industry. The other $\mathrm{S} \times \mathrm{S}$ mating produced 8 people, $6 \mathrm{~S}$ and $2 \mathrm{~L}$. One of these, Ellen, S, married Alan, also $\mathrm{S}$, and had 8 children, $5 \mathrm{~S}$ and $3 \mathrm{~L}$. One of the latter, Reuben, married Mamie, L, whose parents and brothers are all $\mathrm{L}$, and had 5 chitdren, all $\mathrm{L}$. Ulysses, a brother of Reuben, not industrious, married an unindus-

Gen.

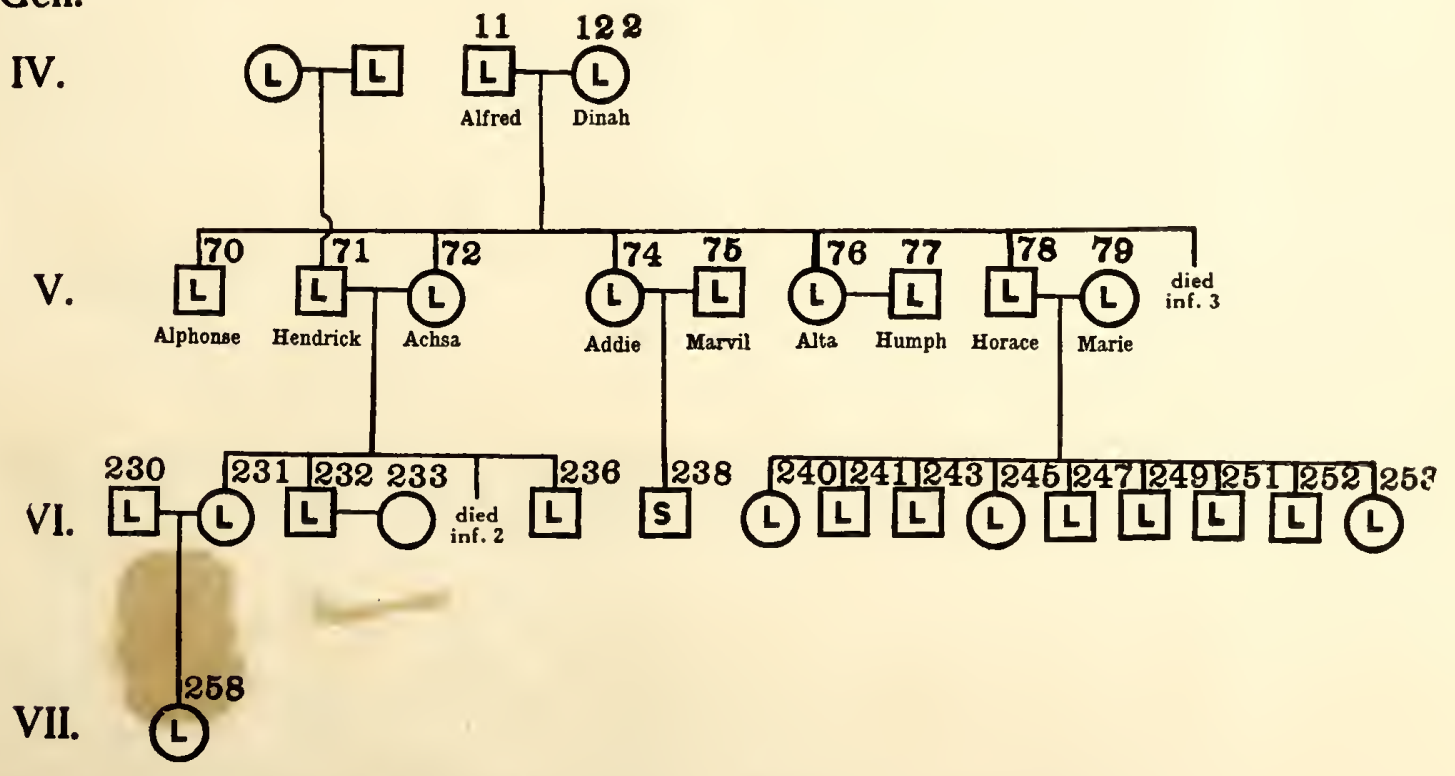

Chart 22.-Group of Jukes showing-occurrence of industriousness.

$\mathrm{L}$, laboriousness or industriousness. $\mathrm{S}$, slothfulness or unindustriousness. 
trious woman whose sibs were both $\mathrm{S}$ and $\mathrm{L}$, and had 6 children, all S. Here a mating of $\mathbf{S} \times \mathbf{S}$ produced both $\mathbf{S}$ and $\mathrm{L}$.

Gen.

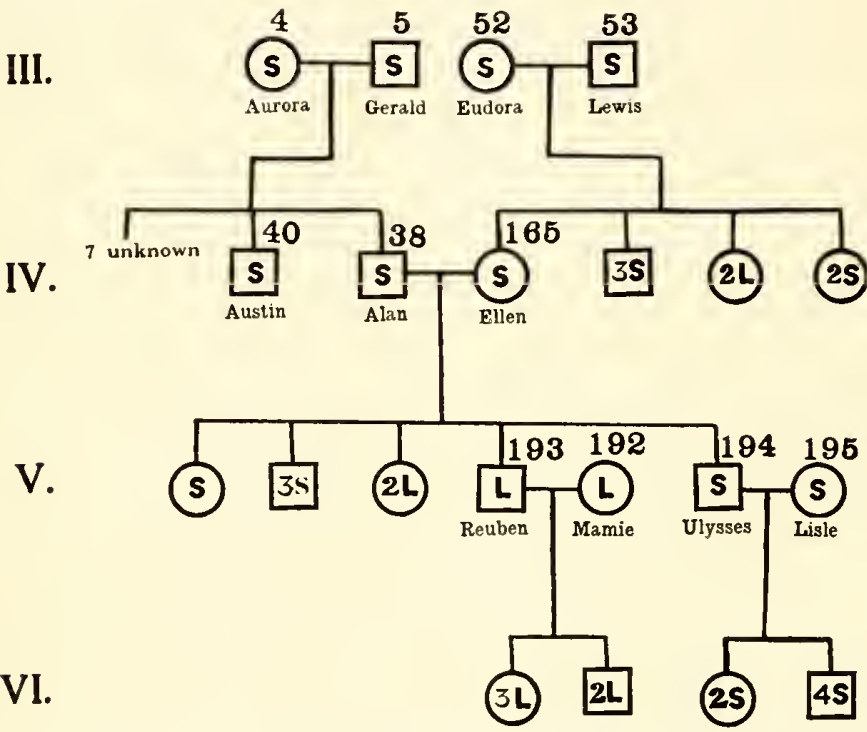

Chart 23.-Group of Jukes showing occurrence of industriousness and unindustriousness.

L, laboriousness. S, unindustriousness. Number in symbol indicates number of persons having that trait.

In chart 24 is found Austin, who is probably $\mathrm{S}$, mated to his cousin Elsie, who is $\mathrm{S}$, producing $4 \mathrm{~S}$ offspring. One of these, Jonas, married Etta, who was unindustrious and whose parents were $\mathrm{S}$, and had $2 \mathrm{~S}$ children. Vergil, a brother of Jonas, married Leah Maria, S, whose father is $\mathrm{S}$ but whose mother is unknown, although remembered by some as L, and they had 1 son, L, and 1 girl who died at 16 years. Vergil then mated with $\mathrm{S}$ and had 2 unindustrious children and 1 still young. Here unindustriousness mated to unindustriousness produces, in general, S offspring, but may produce $\mathrm{L}$.

When $\mathrm{L}$ mates with $\mathrm{S}$, some of the offspring are $\mathrm{S}$ and the rest are I. Janice, IV 164, L, married Elbert, S, and had 6 children, 3 of whom are L; the other 3 are S.

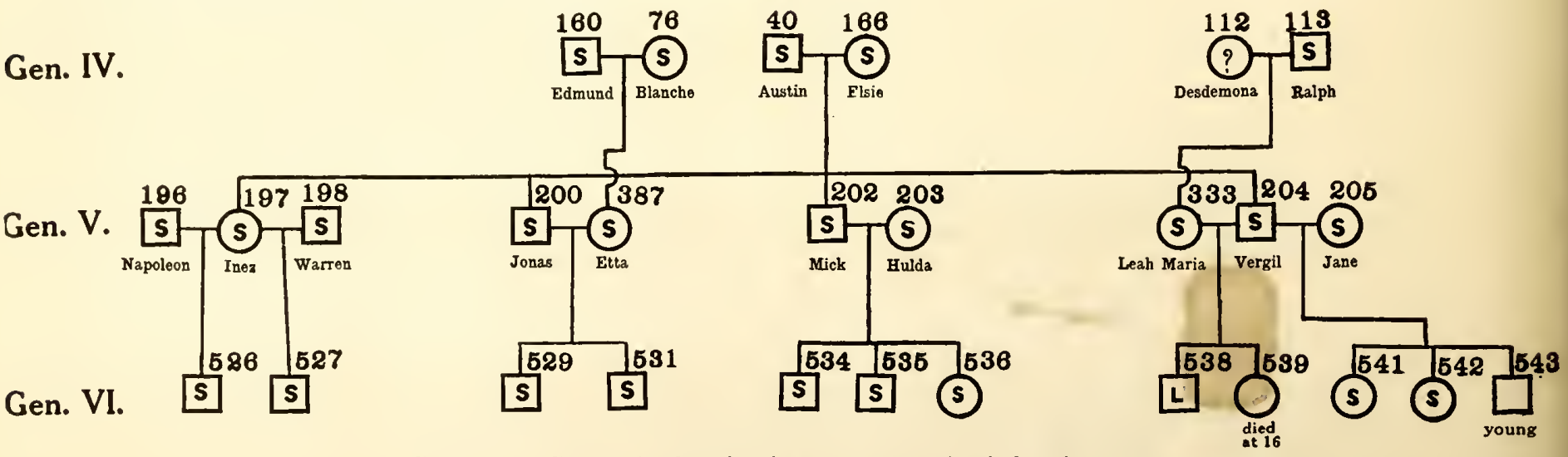

Chart 24.-Group of Jukes showing occurrence of unindustriousness.

\section{BLindness.}

Seventeen of the Jukes, including Max, the progenitor on one side, have been blind. The family distribution of blindness is shown in chart 25 . The cases, amount of Juke blood, cause as far as known, and age at onset of blindness, are given in table 12 .

TABLE 12.-Cases of blindness, designating the Juke strain; cause when known, and age at onset.

\begin{tabular}{|c|c|c|c|c|}
\hline Name. & No. & $\begin{array}{c}\text { Juke } \\
\text { strain. }\end{array}$ & Cause of blindness. & $\begin{array}{l}\text { Age at } \\
\text {-onset. }\end{array}$ \\
\hline Max... & 3 & & & Old age. \\
\hline$\ldots \ldots \ldots$ & III 20 & B. & Cataract. & Old age. \\
\hline Dorcas.......... & III 36 & D.... & $\ldots \ldots$ & Old age. \\
\hline Dwight........ & III 46 & D.... & Blind in one eye... & \\
\hline Earl ........ & III 48 & E.... & $\ldots \ldots \ldots \ldots \ldots$ & Old age. \\
\hline Amanda......... & IV & A B .. & $\ldots$ & Old age. \\
\hline Amy ........... & IV 14 & AC.. & Ophthalmia...... & \\
\hline Ben........... & IV 74 & B C .. & $\ldots \ldots \ldots$ & 50 \\
\hline Barney.... . & IV 75 & B C .. & Injury. & 50 \\
\hline Blanche........ & IV 76 & B C .. & Syphilitic........ & 45 \\
\hline Drusilla........ & IV 148 & D.... & Blind in one eye... & \\
\hline Dean..... & IV 149 & $\mathrm{D}$. & $\ldots \ldots \ldots \ldots \ldots$ & Old age. \\
\hline Elias.. & IV 167 & E.... & $\ldots$ & Old age. \\
\hline Augustus........ & V 13 & A B .. & Syphilis or injury . & 35 \\
\hline Bernice. . & V 245 & B C D. & $\ldots \ldots \ldots \ldots \ldots$ & 30 \\
\hline Howland. & V 248 & B C D. & $\ldots \ldots \ldots \ldots \ldots \ldots$ & 35 \\
\hline Webster........ & V 308 & C.... & $\ldots \ldots \ldots \ldots \ldots$ & 50 \\
\hline
\end{tabular}

Nothing to indicate the manner of inheritance of blindness appears in these data. There is one blind person to every 20,000 of the general population of the United States, while there is one blind person to every 123 in the Jukes. There are more blind males than females. The same is true of the general population. This great discrepancy in the relative amount of blindness in the Jukes in comparison with the general population may be due to various causes; gonorrheal infection, syphilitic infection, filthy living permitting of various other infections, injury. There may be hereditary factors such as are found in cataract, glaucoma, and degenerations of the retina and atrophies of the optic nerve. As it has usually been impracticable to determine the nature of the blindness, it is obvious that these data can not be used for a study of heredity. 


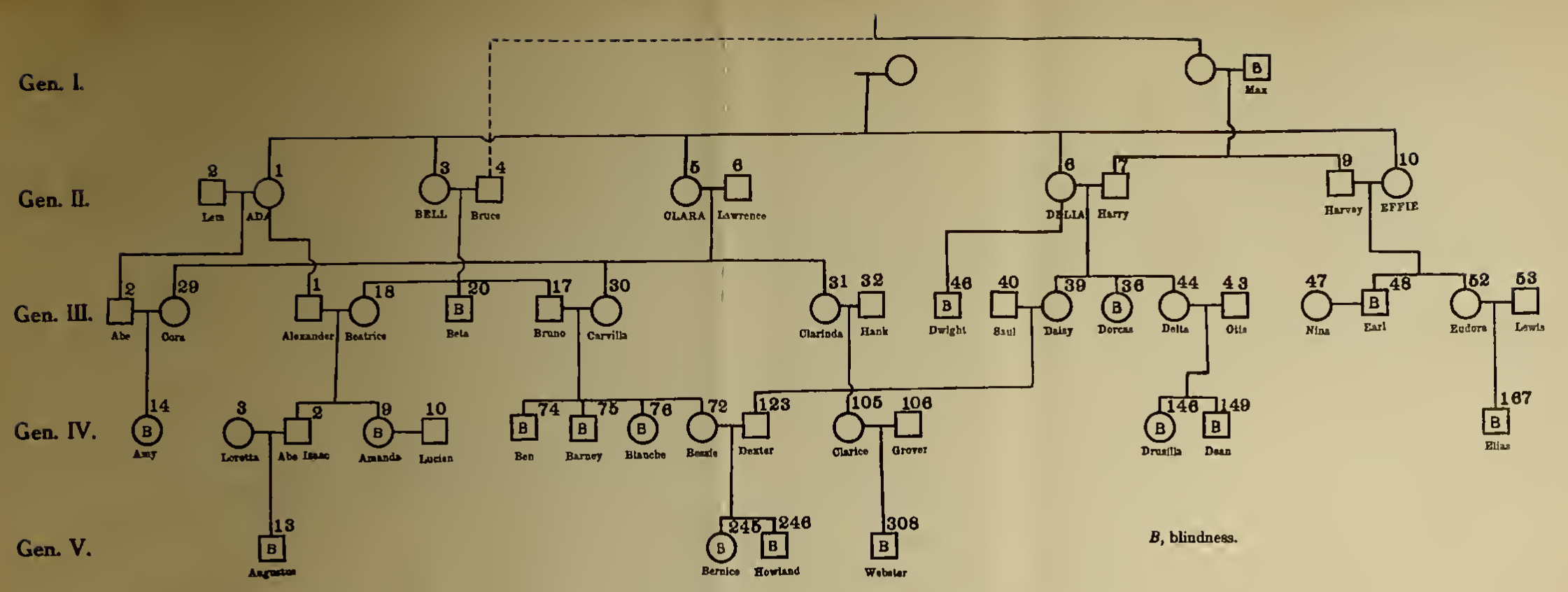

Chart 25. Blindness in Juke Family.

Gen. IV.

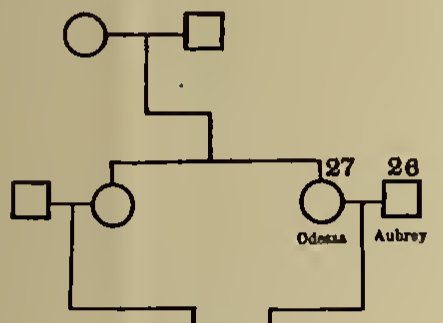

Gen. V.

Gen. VL.

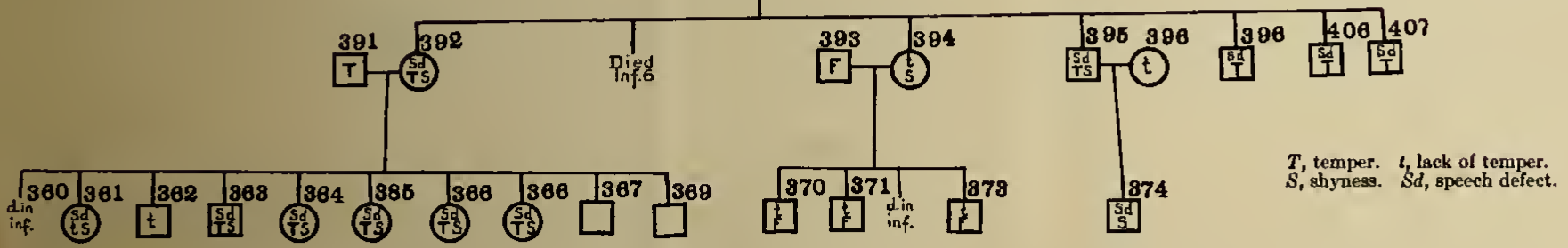

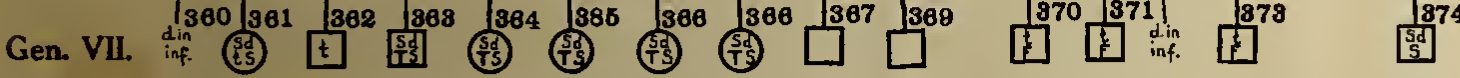

Crart 26. Group of Ada's Legitimate Descendants, showing the Inheritance of Shyness, Temper, and Speech Defect. 



\section{Shyness, Temper, and Speech Defect.}

An interesting case of the inheritance of temper, shyness, and speech defect is found in the legitimate branch of Ada's descendants (chart 26). Nancy, V 156, who is shy and has somewhat of a bad temper, married her first cousin in out blood, Leroy, V 155, who stutters, has a very disagreeable temper, but is not shy. They had 12 children, only 6 of whom reached maturity. Four of these stutter, while a fifth, VI 398, has outgrown stuttering, and a sixth, VI 394, never stuttered but had St. Vitus dance as a young girl. The oldest child, VI 392, with speech defect, also has a bad temper and is shy. She married a man who possessed a high temper and they had 5 children with speech defect, temper, and shyness, 1 with none of these three traits, 1 with speech defect and shyness, 2 still young, and 1 dead. VI 394, who had St. Vitus dance, married a forward man and has 3 of 4 children living, all forward and none with speech defect. VI 395, possessing all the traits under discussion, mated with a woman having none of these traits and had 1 child who had speech defect and was shy but had no temper. The interesting feature of this small pedigree is the group inheritance of these three traits in the offspring of VI 391 and VI 392 . This pedigree shows that temper, $\mathrm{T}$, mated to lack of temper, $\mathrm{t}$, in a cousin-mating produced $5 \mathrm{~T}$ and $1 \mathrm{t}$. $\mathrm{T}$ mated with $\mathrm{T}$ (VI 392 and VI 391) produced $5 \mathrm{~T}$ out of 7 , while $\mathrm{T}$ mated to $t$ in an out-mating (VI 395 and VI 396) produced a child without temper. It has already been shown (Eugenics Record Office Bulletin No. 12) that the tendency to intermittent outbreaks of bad temper is a dominant trait.

\section{Twinning.}

Four cases of twinning appear in the study (chart 27): three from one mother and one by her brother's daughter. There is nothing to show the manner of inheritance.

\section{Gen.}

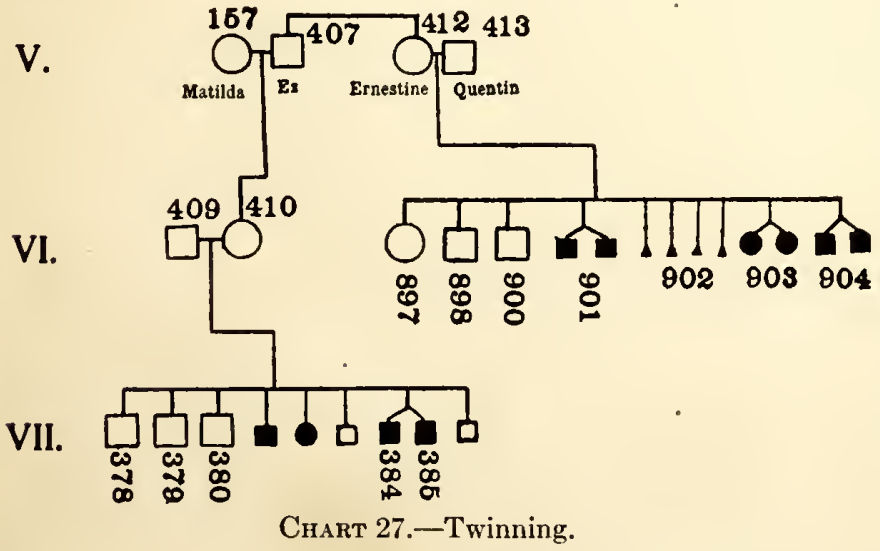

10. Absence of Harelip and Cleft Palate in the

The statement has been frequently made by physicians and others that the presence of harelip and cleft palate is due to the imperfect development of the individual during fetal life and that, therefore, these structures are to be found more often in mentally defective stock, where imperfect development is frequent. Special attention has been paid to this subject in the investigation of the Jukes, but not a single case of these aberrations has been discovered. Some of the many children who died at birth or in infancy may have possessed these conditions, but none came to light. The absence of harelip and cleft palate in the Jukes, then, where so much mental deficiency is found, is interesting in view of the above statement.

\section{CHANGED ENVIRONMENT.}

\section{Voluntary Removals to a New Country.}

The description of the home of the first Jukes has been given earlier in this book. It was in a rock-rimmed area of a few acres. In 1850 the population of this area had gradually become more dense and some of the more energetic and active Jukes migrated to neighboring communities and settled there. The cement mines closed in 1870 and the remaining Jukes in the ancestral area left, since no steady occupation remained for anyone. The more feebleminded and shiftless ones removed to other localities physiographically similar to the one in which they had lived, but rather nearer the centers of population and the prosperous farming areas. The energetic ones went into good farming sections or into the cities. At this time several groups went to Connecticut, others to New York City or its environs, while others went to New Jersey. A short time previous to this general exodus, Ella and Homer, chart 6, had gradually migrated West and finally settled in Minnesota. About 1850, the children of Uriah, grandson of Bell, went to Pennsylvania, but Dugdale left no note of where or why they had gone. The effect of the changed environment in the remote removals will be studied in two classes: (1) the class comprising those Jukes who married out into the families in the new region, and (2) the class comprising Jukes that intermarried with Jukes who had migrated with them.

Two sons of Annetta, V37, went to New York, where they secured steady employment and are good citizens. A brother of these, VI 128, remained in the Juke country and is now a poor, semi-industrious laborer, who married a feeble-minded woman and has feeble-minded children. A sister of these, VI 121, had several children who went to New York City and are good, industrious citizens.

Alice Ella, V 28, a harlot, married, went to New York City, and had one son, VI 89, who started a business, has done well financially, and is a reputable citizen. He has four children, all of whom are reputable and industrious, though mentally somewhat mediocre.

Harriet, V 319, after having two illegitimate children, married and went to New Jersey. Her oldest child remained in the Juke country and became a criminal. The other illegitimate child grew up in New Jersey and proved to be only semi-industrious, became a harlot, and had illegitimate children. Three of Harriet's legitimate children were in a Children's Home at one time and are now either dead or unknown, while a fourth is an ignorant, 
hard-working woman with four children who are doing very poorly in school.

Ella, IV 170, of Juke blood, married Homer, IV 169, of outside blood, went West in 1850, as mentioned above, and, finally, settled in Minnesota, where they reared seven children, who in turn have produced many offspring.

The descendants of the Ella-Homer marriage have all been brought up in Minnesota, in a community entirely unlike the Juke home community and where they were not handicapped on account of their family name. Only two of the descendants of Ella can be called socially good citizens. The rest are either mentally defective, licentious, semi-industrious, or dishonest. The only explanation of this is heredity: the common ancestor of this western group, Ella, herself not anti-social, had brothers and sisters who were the most vicious and depraved of all the Jukes. These same traits have appeared in her children, though not to such a marked degree and consequently not so capable of social damage. Not one of this western group has ever been arrested, although several are dishonest and have stolen money, and many are licentious. Here heredity has been more potent than the environment, but the behavior of the anti-social individuals produced in this group has been tempered by an improved environment. The future of this group looks more hopeful, as the younger generation is marrying into better stocks and so the general mental and social average of this family will gradually rise.

Several families scattered here and there among the Jukes went into Connecticut. Most of these married out, but one married a cousin and this resulted in a cacogenic mating. In the first group are found Jane Ann (IV 90), Franklin (V 170), Adam (V 47), Joel (V 427), Elmira (V 423), and VI 216; while in the last group is VI 925, who married her cousin, VI 845.

Jane Ann's children were born in the Juke country, but when very young went with their mother to Connecticut. Here they settled in a manufacturing town. One son, Miles, V 292, is an alcoholic who married into " $\mathrm{X}$ " blood in Connecticut and has seven defective children and one who is doing well. The other children of Jane Ann in Connecticut were ignorant, mentally inactive, and harl no descendants.

Franklin, V 170, and VI 216 were brothers in the out-blood of the Juke country. They both married Juke women. The former married Sarah, V 171, who was ignorant, alcoholic, but industrious, while the other married VI 215, a fecbleminded harlot. The two couples moved to Connecticut, where their children grew up. VI 215 and VI 216 had two socially inadequate children and one other, who, although a prostitute before marriage, married well and is now a reputable woman with three mentally and socially fit children. Franklin and Sarah had six children who reached maturity; four of these are socially good citizens, married into good stocks in Connecticut, and are breeding capable children, while two are mentally slow and only semi-efficient, and of these, one, who is married, has three children, two of whom are mentally slow, while the third is average in school and has good traits.

Adam, V 47, went with his wife and three small children to Connecticut to escape detection after a crime. The two sons became criminal, while the daughter, who was reputable, married well and now has one child.

Joel, V 427, married Estella for his second wife and they moved to Connecticut with her sister Elmira and her second husband. Estella's children are all socially good. Some are capable in school, others are not. Elmira's children, by her first husband, a cousin, were born in New York State but reared in Connecticut, and her two children by the last mating were born in Connecticut. All were slow in their school work, three are industrious, have married out into fair stock, and give good promise of rearing offspring more fit than their Juke ancestors.

The one cousin-mating of Juke blood in remote country here appears. VI 925, the third child of Elmira, was reared in Connecticut, but, instead of marrying into new blood, mated with her second cousin, VI 845, an indolent, inefficient, licentious laborer. They have six children, three of whom, now old enough to attend school, are retardcd, while the oldest child has recently been sent to the School for Wayward Girls, being a prostitute at the age of 15 .

In reading the above it will be seen that migrations to ncw localities with out-breeding into better stocks is slowly lifting the family to a higher social plane. In some cases mating of Jukes with stocks like their own produce like offspring. When Jukes mate with Jukes the resultant offspring is cacogenic. The Minnesota group is slowly elevating itself, mentally and morally, by marriages with out-bloods, but this out-mating into better stocks has taken place but recently and the good effect is only slowly bccoming apparent.

\section{Involuntary Removals.}

Society, through its charity organizations, has taken many Juke children from poor living conditions and transferred them to distant homes. A list of all Jukes who were placed in any institution before the age of 21 , except in jails and State prison, is found in table 13 on Institutional care. Out of 118 individuals, 33 have been placed in foster homes either in the Juke region, in New York State, or in the Middle West; 16 of these 33 have been placed in foster homes in the Middle West, where there is little chance that they will return to their Juke brethren; 7 of these are doing well; 9 are doing poorly. A child is classed as doing poorly if he is three or more years retarded in his school work (providing he has attended school regularly for several years) and does not respond to the customs and rules of the home in which he is placed. There were 17 placed in foster homes in or near New York State; trace of 2 of these has been lost, 8 are doing well, while 7 have done poorly. When it is considered that in all probability all of these would have been poor citizens had they remained in the environment from which they were taken, the result would seem to approve the action of society in removing them from their poor surroundings. But such approval can not be given unreservedly. All of them, with perhaps the exception of 3 or 4 , must carry in their germ-plasm the determiner's for certain undesirable traits, such as alcoholism, epilepsy, and licentiousness. This is shown by a sturly of their immediate ancestors. Unless 
these indivigduals mate intelligently with a thought to their future offspring much social clamage may be done by introducing into new localities germ-plasms such as these of the Jukes. VI 226, whose parents were criminal, was placed out in the Middle West when 9 years old, and adopted into a good family. At 42 he is married and procreating children who though young already show retardation in their school work. It would have been better for the future race had these parents been kept under some sort of supervision and their capacity for reproduction restricted. The 9 socially unfit, now in the Middle West, will likely mate with others like themselves and so start new Juke strains. The 7 now in the West who are doing well will mate higher than the others, but their hidden defects, present in the germ-plasm, may crop out and so cause social and mental deficiency. Not even the improved environment counteracts the innate defects of the Jukes.

\section{INSTITUTIONAL CARE.}

\section{Children's Institutions.}

In the last 20 years many institutions have arisen which have specialized in the treatment of delinquency in children; and we find that many Jukes have been inmates of these institutions. Children's institutions, as such, were unknown in the Juke country until 1875 , and consequently many of the children who were neglected at that time were sent to the almshourse. Subsequent to 1875 children delinquent througl their own or their parents' shortcomings were sent either to a Children's Home or to the House of Refuge, which, at that time, received children who were not criminal as well as those who had committed "crime."

The result of institutional care upon Jukes under the age of 21 is shown in table 13. The summary of this table is on page $76 ; 118$ or about 6 per cent of the total number of Jukes under the age of 21 lave been under care in some State or private institution of a charitable or correctional nature; those who committed felonies or have been sent to jail under the age of 21 are not included in this table; 27 , or 23 per cent, have done well in the general community after leaving the institution; 63 did poorly on leaving the institution, while 16 have been lost trace of ; 6 died under 21 year's of age, and it could not be determined what the effect of the institution was on these. There are now 9 Jukes under the age of 21 in children's institutions. Three are in permanent custodial care and 6 now in training; 3 are doing well, while 3 are doing poorly.

The different effects of institutional training upon the members of a fraternity when given under the age of 21 is apparent from a study of table 13. A few comparisons of the people trained in institutions with those of the same fraternity not thus trained, but remaining in society at large, will be given.

TABLE 13.-Institutional care.

\begin{tabular}{|c|c|c|c|c|c|c|c|c|c|}
\hline \multirow{2}{*}{ No. } & \multirow{2}{*}{$\begin{array}{l}\text { Genera- } \\
\text { tion and } \\
\text { serial } \\
\text { No. }\end{array}$} & \multirow{2}{*}{ Sex. } & \multirow{2}{*}{$\begin{array}{l}\text { Date } \\
\text { of } \\
\text { birth. }\end{array}$} & \multicolumn{2}{|c|}{ Description of parents. } & \multirow{2}{*}{$\begin{array}{l}\text { Description of } \\
\text { individual when } \\
\text { removed to } \\
\text { institution. }\end{array}$} & \multirow{2}{*}{$\begin{array}{c}\text { Age } \\
\text { at } \\
\text { re- } \\
\text { mov- } \\
\text { al. }\end{array}$} & \multirow{2}{*}{$\begin{array}{l}\text { Institutional and } \\
\text { subsequent care. }\end{array}$} & \multirow{2}{*}{$\begin{array}{l}\text { Behavior after leaving } \\
\text { institution. }\end{array}$} \\
\hline & & & & Father. & Mother. & & & & \\
\hline 1 & IV 24 & M. & 1837 & $\begin{array}{l}\text { Pauper, licen- } \\
\text { tious, poor- } \\
\text { house at } 52 \text {. }\end{array}$ & Good reputation. & Neglected... & 12 & $\begin{array}{l}\text { Poorhouse with } \\
\text { father. }\end{array}$ & $\begin{array}{l}\text { Returned to poorhouse in old } \\
\text { age. }\end{array}$ \\
\hline 2 & V 1 & F. & 1821 & $\begin{array}{l}\text { Licentious, in- } \\
\text { temperate, re- } \\
\text { ceived poor re- } \\
\text { lief. }\end{array}$ & Harlot.... & $\ldots$ Do & 10 & Poorhouse 4 years. . & $\begin{array}{l}\text { Poorhouse again at 18; confined } \\
\text { there; licentious; peniten- } \\
\text { tiary. }\end{array}$ \\
\hline 3 & V 6 & M. & 1836 & ..... Do....... & .... Do. . & $\begin{array}{l}15 \text { years old when } \\
\text { mother died. }\end{array}$ & 17 & $\begin{array}{l}\text { Poorhouse } 2 \text { years; } \\
\text { bound out. }\end{array}$ & Intemperate; criminal. \\
\hline 4 & V 10 & M. & 1837 & $\ldots$ Do & . . Do & $\begin{array}{l}14 \text { years old when } \\
\text { mother died. }\end{array}$ & 14 & Poorhouse 1 year. . & Do. \\
\hline 5 & V 13 & M. & 1839 & $\ldots$ Do & . Do & $\begin{array}{l}12 \text { years old when } \\
\text { mother died. }\end{array}$ & 12 & Poorhouse 4 years.. & $\begin{array}{l}\text { At } 17 \text {, county jail; criminal } \\
\text { career. }\end{array}$ \\
\hline 6 & V 15 & F. & 1843 & $\ldots$... Do & ..... Do & $\begin{array}{l}8 \text { years old when } \\
\text { mother died. }\end{array}$ & 8 & .....Do.. & Harlot; died at 30. \\
\hline 7 & V 17 & M. & 1845 & .... Do & ...... Do. & $\begin{array}{l}7 \text { years old when } \\
\text { mother died. }\end{array}$ & 7 & ..... Do & Criminal career. \\
\hline 8 & V 19 & M. & 1848 & .... Do & .... Do & $\begin{array}{l}4 \text { years old when. } \\
\text { mother died. }\end{array}$ & 4 & ....Do & $\begin{array}{l}\text { Poorhouse again at } 24 \text {; outdoor } \\
\text { relief; now industrious, but } \\
\text { poor and inefficient. }\end{array}$ \\
\hline 9 & V 84 & F. & 1840 & $\begin{array}{l}\text { In tempera te, } \\
\text { weak-minded. }\end{array}$ & Kept brothel. . & Vagrant, harlot... & 17 & Poorhouse... & $\begin{array}{l}\text { Career of harlotry; 2 bastard } \\
\text { children. }\end{array}$ \\
\hline 10 & V 112 & F. & 1854 & $\begin{array}{l}\text { In tempera te, } \\
\text { criminal. }\end{array}$ & Harlot, syphilitic. & Pregnant. . & 18 & Poorhouse 1 year.. & Harlot; bastard children. \\
\hline 11 & V 120 & F. & 1862 & 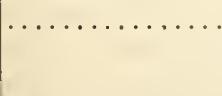 & Harlot... & & . & $\begin{array}{l}\text { Born in poorhouse; } \\
\text { adopted in t o } \\
\text { wealthy family. }\end{array}$ & Reputed doing well in 1875. \\
\hline 12 & V 345 & M. & 1858 & $\begin{array}{l}\text { Alcoholic, semi- } \\
\text { industrious. }\end{array}$ & .... Do & Neglected... & 14 & $\begin{array}{l}\text { House of Refuge } 2 \\
\text { years. }\end{array}$ & $\begin{array}{l}\text { Intemperate, inefficient, licen- } \\
\text { tious. }\end{array}$ \\
\hline
\end{tabular}


TABLE: 13.-Institutional care-Continued.

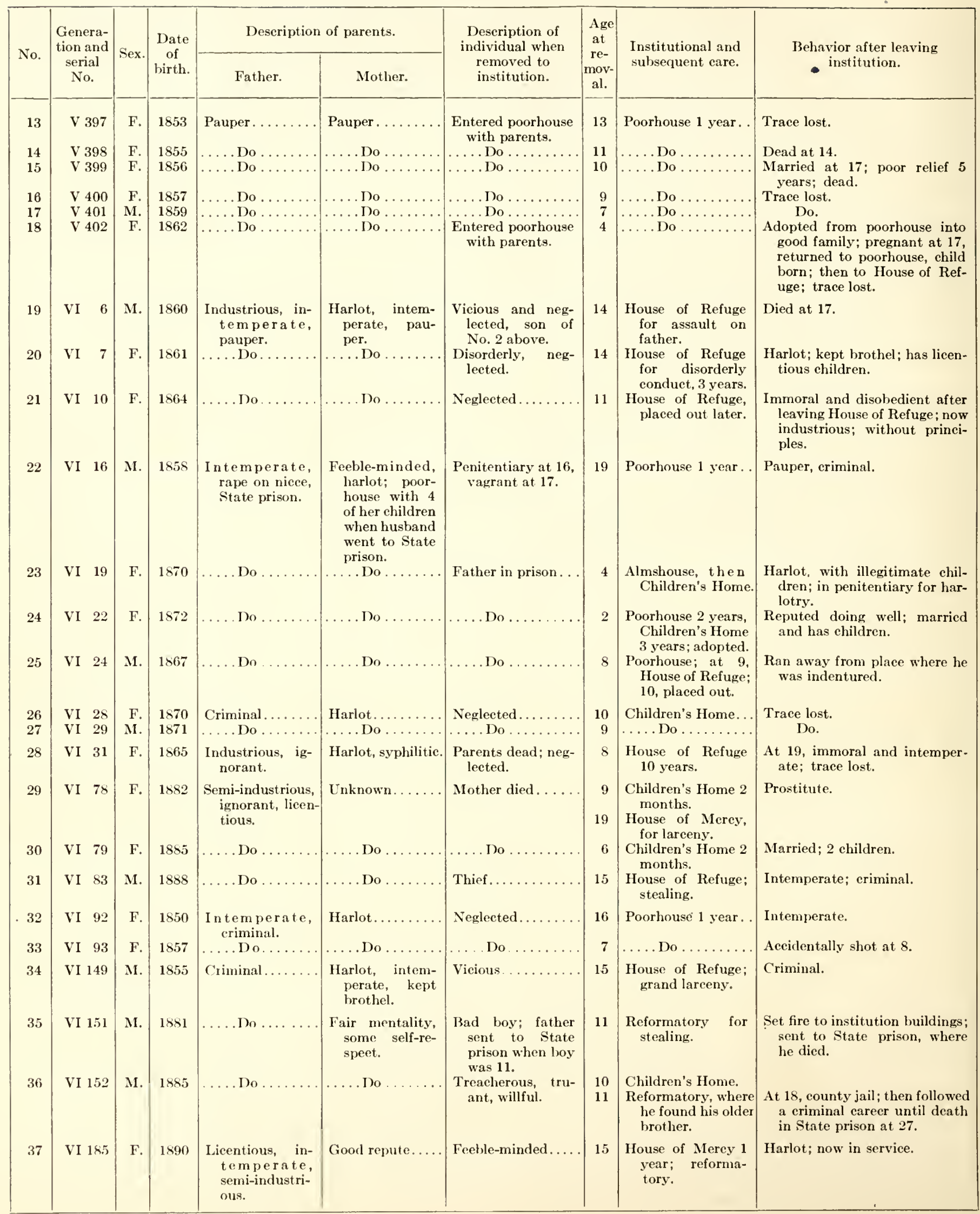


TABLE 13.-Institutional care-Continued.

\begin{tabular}{|c|c|c|c|c|c|c|c|c|c|}
\hline \multirow{2}{*}{ No. } & \multirow{2}{*}{$\begin{array}{l}\text { Genera- } \\
\text { tion and } \\
\text { serial } \\
\text { No. }\end{array}$} & \multirow{2}{*}{ Sex. } & \multirow{2}{*}{$\begin{array}{l}\text { Date } \\
\text { of } \\
\text { birth. }\end{array}$} & \multicolumn{2}{|c|}{ Description of parents. } & \multirow{2}{*}{$\begin{array}{l}\text { Description of } \\
\text { individual when } \\
\text { rcmoved to } \\
\text { institution. }\end{array}$} & \multirow{2}{*}{$\begin{array}{l}\text { Age } \\
\text { at } \\
\text { re- } \\
\text { mov- } \\
\text { al. }\end{array}$} & \multirow{2}{*}{$\begin{array}{l}\text { Institutional and } \\
\text { subscquent eare. }\end{array}$} & \multirow{2}{*}{$\begin{array}{l}\text { Behavior after leaving } \\
\text { institution. }\end{array}$} \\
\hline & & & & Father. & Mother. & & & & \\
\hline 38 & VI 207 & F. & 1863 & Criminal. & Harlot.. & Negleeted..... & 11 & $\begin{array}{l}\text { House of Refuge } 2 \\
\text { years. }\end{array}$ & $\begin{array}{l}\text { Harlot; died in house of prosti- } \\
\text { tution. }\end{array}$ \\
\hline 39 & VI 209 & M. & 1864 & $\ldots$ Do & .... Do & $\ldots$ Do. & 10 & House of Refuge... & $\begin{array}{l}\text { Suspicious; mentally below aver- } \\
\text { age; semi-industrious; lias } \\
\text { saverl a little money. }\end{array}$ \\
\hline 40 & VI 210 & F. & 1866 & ..... Do & $\ldots$ Do & $\ldots$ Do & $\begin{array}{r}8 \\
11 \\
16\end{array}$ & 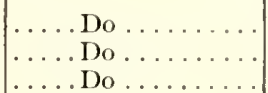 & $\begin{array}{l}\text { Discharged, but each time re- } \\
\text { turned as disorderly; became } \\
\text { harlot and died at } 29 \text {. }\end{array}$ \\
\hline 41 & VI 211 & M. & 1871 & $\ldots$ Do $\ldots$ & .... Do........ & $\begin{array}{l}\text { Arrested for petit } \\
\text { larceny. }\end{array}$ & 10 & $\ldots$ Do $\ldots \ldots \ldots$ & Subsequent career of erime. \\
\hline 42 & VI 217 & F. & 1857 & $\begin{array}{l}\text { Thief, pauper, } \\
\text { semi-industri- } \\
\text { nus. }\end{array}$ & $\begin{array}{l}\text { Harlot; contriver } \\
\text { of erime. }\end{array}$ & Vagrant......... & $\begin{array}{r}7 \\
17\end{array}$ & $\begin{array}{l}\text { Poorhouse } 1 \text { year. } \\
\text { House of Refuge... }\end{array}$ & Harlot. \\
\hline 43 & VI 220 & M. & 1859 & $\ldots$ Do ........ & ..... Do. & ..... Do $\ldots \ldots$ & 15 & $\begin{array}{l}\text { House of Refuge } 2 \\
\text { years. }\end{array}$ & Intemperate criminal. \\
\hline 44 & VI 222 & M. & 1861 & $\ldots$ Do & $\ldots$ Do & "Disorderly" $\ldots \ldots$ & $\begin{array}{r}2 \\
13\end{array}$ & $\begin{array}{l}\text { Poorhouse with } \\
\text { mother. } \\
\text { House of Refuge } 2 \\
\text { years. }\end{array}$ & $\begin{array}{l}\text { Alcoholic, fecble-minded, vi- } \\
\text { cious. }\end{array}$ \\
\hline 45 & VI 224 & M. & 1869 & $\ldots$.... Do & $\ldots$ Do & Vagrant & 12 & Children's Home... & Died at 12 \\
\hline 46 & VI 226 & M. & 1872 & ..... Do & ..... Do & No home......... & 9 & $\begin{array}{l}\text { Children's Home; } \\
\text { placed out in } \\
\text { private family in } \\
\text { Middle West. }\end{array}$ & $\begin{array}{l}\text { At } 42 \text {, ignorant; has received } \\
\text { poor relief; licentious, but not } \\
\text { criminal. }\end{array}$ \\
\hline 47 & VI 256 & F. & 1872 & $\begin{array}{l}\text { Licentious, indus- } \\
\text { trious. }\end{array}$ & Good woman.... & Harlot; pregnant... & 19 & $\begin{array}{l}\text { Poorhouse, where } \\
\text { bastard was }\end{array}$ & Harlot. \\
\hline 48 & VI 261 & F. & 1879 & ..... Do & ..... Do & Wayward......... & 15 & $\begin{array}{l}\text { born. } \\
\text { House of Refuge } 1 \\
\text { year; placed out. }\end{array}$ & $\begin{array}{l}\text { Married and has ehildren; } \\
\text { clandestine prostitute, good } \\
\text { appearance. }\end{array}$ \\
\hline 49 & VI 276 & F. & 1880 & $\begin{array}{l}\text { Inefficient, licen- } \\
\text { tious, intem- } \\
\text { perate. }\end{array}$ & Harlot......... & Destitute........ & 10 & $\begin{array}{l}\text { Children's Home } 2 \\
\text { years; placed out. }\end{array}$ & $\begin{array}{l}\text { Inefficient, ignorant, mentally } \\
\text { defective. }\end{array}$ \\
\hline 50 & VI 280 & M. & 1870 & $\begin{array}{c}\text { Intem perate } \\
\text { not industri- }\end{array}$ & ..... Do & $\begin{array}{l}\text { Poorhouse with } \\
\text { mother. }\end{array}$ & 7 & $\begin{array}{l}\text { Poorhouse, then } \\
\text { Children's Home. }\end{array}$ & Trace lost. \\
\hline 51 & VI 281 & M. & 1873 & ous. & .... Do & $\ldots$ Do $\ldots \ldots \ldots$ & 4 & $\ldots$ Do .......... & Do. \\
\hline 52 & VI 345 & M. & 1883 & Not industrious. & Harlot. & No home... & 10 & Children's Home... & Do. \\
\hline 53 & VI 346 & F. & 1884 & ......Do & $\ldots . \mathrm{Do}$ & $\ldots$ Do & 9 & $\ldots \ldots D_{0} \ldots . . . .$. & Do. \\
\hline 54 & VI 347 & F. & 1885 & ..... Do. & $\ldots$ Do & ..... Do & 8 & 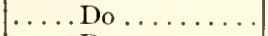 & Do. \\
\hline 55 & VI 348 & F. & 1890 & $\ldots$ Do ........ & ..... Do & $\ldots$........ & 5 & $\ldots$..... Do .......... & Do. \\
\hline 56 & VI 459 & F. & 1858 & Unknown. & Harlot, pauper .. & No home......... & 16 & $\begin{array}{l}\text { House of Refuge, } \\
\text { disorderly con- } \\
\text { duct; placed in } \\
\text { good religious } \\
\text { home. }\end{array}$ & $\begin{array}{l}\text { Had illegitimate child which } \\
\text { died; married a worthless } \\
\text { man and had } 8 \text { children whom } \\
\text { she has brought up well; } \\
\text { neat and industrious. }\end{array}$ \\
\hline 57 & VI 513 & F. & 1885 & $\begin{array}{l}\text { Inefficient, licen- } \\
\text { tious, intem- } \\
\text { perate. }\end{array}$ & Harlot......... & Disorderly........ & 15 & $\begin{array}{l}\text { Reformatory for } \\
\quad \text { prostitution } \\
\text { years. }\end{array}$ & $\begin{array}{l}\text { Married; has children; now a } \\
\text { harlot. }\end{array}$ \\
\hline 58 & VI 720 & F. & 1859 & Soldier, dead .... & $\begin{array}{l}\text { Syphilis, lazy, } \\
\text { harlot. }\end{array}$ & $\begin{array}{l}\text { Harlot, syphilis, } \\
\text { poor. }\end{array}$ & 18 & $\begin{array}{l}\text { Poorhouse with } \\
\text { mother. }\end{array}$ & Harlot; feeble-minded. \\
\hline 59 & VI 723 & F. & 1871 & Unknown....... & 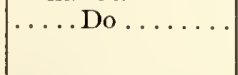 & Neglected........ & $\begin{array}{l}5 \\
6\end{array}$ & $\begin{array}{l}\text { Poorhouse } 1 \text { year. } \\
\text { Children's Home... }\end{array}$ & Trace lost. \\
\hline 60 & VI 725 & M. & 1877 & $\begin{array}{l}\text { Ignorant, ineffi- } \\
\text { cient, licen- } \\
\text { tious. }\end{array}$ & $\begin{array}{l}\text { Feeble-m in d ed } \\
\text { harlot. }\end{array}$ & $\begin{array}{l}\text { With parents at } \\
\text { poorhouse. }\end{array}$ & 1 & Poorhouse....... & Criminal; now in State prison. \\
\hline $\begin{array}{l}61 \\
62\end{array}$ & VI 727 & M. & 1875 & $\ldots$ Do ........ & ..... Do. & $\ldots \ldots$ Do $\ldots . . .$. & 3 & $\ldots$ Do .......... & Ignorant, inefficient. \\
\hline 62 & VI 728 & M. & 1872 & $\ldots$.... Do ....... & $\ldots$ Do........ & Neglected........ & $\begin{array}{l}3 \\
5 \\
6\end{array}$ & $\begin{array}{l}\text { Children's Home. } \\
\text { Placed out. }\end{array}$ & $\begin{array}{l}\text { Deserted wife and } 3 \text { children to } \\
\text { be worker in a religious organ- } \\
\text { ization; inefficient; no prin- } \\
\text { ciples. }\end{array}$ \\
\hline 63 & VI 735 & F. & 1887 & $\ldots D_{0} \ldots \ldots$ & $\ldots$ Do. & $\begin{array}{l}\text { Neglected and fee- } \\
\text { ble-minded. }\end{array}$ & $\begin{array}{r}2 \\
14 \\
20\end{array}$ & $\begin{array}{l}\text { Poorhouse many } \\
\text { times. } \\
\text { Prostitute; sent to } \\
\text { House of Shelter. } \\
\text { Custodial asylum } \\
\text { for life. }\end{array}$ & Harlot; feeble-minded. \\
\hline 64 & VI 743 & F. & 1867 & Semi-industrious. & Harlot. & Neglected. & 10 & Children's Home... & Trace lost. \\
\hline 65 & VI 744 & M. & 1872 & ..... Do ......... & $\ldots$ Do & .... Do ... & 5 & $\ldots$ Do .......... & $\begin{array}{l}\text { Ran away from foster home; } \\
\text { trace lost. }\end{array}$ \\
\hline 66 & VI 747 & M. & 1873 & $\ldots$ Do & Do & $\ldots$ Do & 4 & Children's Home.. & Died at 12 . \\
\hline
\end{tabular}


TABLE 13.-Institutional care-Continued.

\begin{tabular}{|c|c|c|c|c|c|c|c|c|c|}
\hline \multirow{2}{*}{ No. } & \multirow{2}{*}{$\begin{array}{l}\text { Genera- } \\
\text { tion and } \\
\text { serial } \\
\text { No. }\end{array}$} & \multirow{2}{*}{ Sex. } & \multirow{2}{*}{$\begin{array}{c}\text { Date } \\
\text { of } \\
\text { birth. }\end{array}$} & \multicolumn{2}{|c|}{ Description of parents. } & \multirow{2}{*}{$\begin{array}{l}\text { Description of } \\
\text { individual when } \\
\text { removed to } \\
\text { institution. }\end{array}$} & \multirow{2}{*}{$\begin{array}{c}\text { Age } \\
\text { at } \\
\text { re- } \\
\text { mov- } \\
\text { al. }\end{array}$} & \multirow{2}{*}{$\begin{array}{l}\text { Institutional and } \\
\text { subsequent care. }\end{array}$} & \multirow{2}{*}{$\begin{array}{l}\text { Behavior after leaving } \\
\text { institution. }\end{array}$} \\
\hline & & & & Father. & Mother. & & & & \\
\hline 67 & VI 764 & M. & 1905 & $\begin{array}{l}\text { Inefficicnt, intem- } \\
\text { perate. }\end{array}$ & Harlot. & Neglected..... & 7 & $\begin{array}{l}\text { Children's Home; } \\
\text { placed out. }\end{array}$ & $\begin{array}{l}\text { Doing well in behavior and } \\
\text { school work; good physique. }\end{array}$ \\
\hline 68 & VI 798 & M. & 1885 & $\begin{array}{l}\text { Industrious, tried } \\
\text { to do well. }\end{array}$ & . Do & $\begin{array}{l}\text { Arrested for lar- } \\
\text { eeny. }\end{array}$ & 14 & $\begin{array}{l}\text { Housc of Refuge } 2 \\
\text { years. }\end{array}$ & Career of petty crime. \\
\hline 69 & VI 832 & F. & 1893 & $\begin{array}{l}\text { Semi-efficient, in- } \\
\text { temperate. }\end{array}$ & . Mo & Harlot, pregnant... & 17 & $\begin{array}{l}\text { Hospital, where } \\
\text { bastard child } \\
\text { was born; child } \\
\text { died. }\end{array}$ & $\begin{array}{l}\text { Had another bastard which lived } \\
\text { now married. }\end{array}$ \\
\hline 70 & VI 858 & $\mathrm{M}$. & 1903 & Ignorant, boorish. & Harlot, syphilis. & $\begin{array}{l}\text { Father and mother } \\
\text { both dead; found } \\
\text { in hovel. }\end{array}$ & 9 & $\begin{array}{l}\text { Children's Home; } \\
\text { placed out. }\end{array}$ & $\begin{array}{l}\text { Fair mentality; physically weak } \\
\text { eonstitutional syphilis. }\end{array}$ \\
\hline 71 & VI 859 & F. & 1909 & ... Do & ..... Do & Do & 3 & $\begin{array}{l}\text { Children's Home } 1 \\
\text { year; placed out. }\end{array}$ & Did well in Children's Home. \\
\hline 72 & VI 951 & F. & 1889 & $\begin{array}{l}\text { Feeble-minded, } \\
\text { died in State } \\
\text { prison while } \\
\text { serving tern } \\
\text { for rape on his } \\
\text { daughter. }\end{array}$ & Harlot. . & $\begin{array}{l}\text { Harlot; incest with } \\
\text { father. }\end{array}$ & $\begin{array}{l}17 \\
17 \\
19\end{array}$ & $\begin{array}{l}\text { Almshouse........ } \\
\text { House of Mercy. } \\
\text { Reformatory for } \\
\text { prostitution. }\end{array}$ & Died at 22. \\
\hline 73 & VI 952 & $\mathrm{~F}$. & 1896 & $\ldots$.... Do ......... & . 30 & Neglected rliild... & 12 & $\begin{array}{l}\text { Children's Home; } \\
\text { placed out in } \\
\text { Middle West. }\end{array}$ & $\begin{array}{l}\text { School, retarded } 3 \text { years; doing } \\
\text { well socially; ncat, quiet- } \\
\text { mannered, industrious; at } 18 \text {, } \\
\text { moral. }\end{array}$ \\
\hline 74 & VI 954 & M. & 1900 & .... Do & Do & ..... Do & 8 & ..... Do & $\begin{array}{l}\text { Retarded } 3 \text { years at school; lazy } \\
\text { at times; hard to control. }\end{array}$ \\
\hline 75 & VI 956 & M. & 1901 & Do 0 & Do & $\ldots$ Do & 7 & ..... Do . & $\begin{array}{l}\text { Very poor in school work; un- } \\
\text { controllable; has bad temper. }\end{array}$ \\
\hline 76 & VI 958 & M. & $190-4$ & $\ldots$ Do & Do & ... Do & 4 & .... Do. & $\begin{array}{l}\text { Slow in school, hard to control } \\
\text { in foster home; not doing well. }\end{array}$ \\
\hline 77 & VI 1009 & M. & 1896 & $\begin{array}{l}\text { Inefficicnt, vi- } \\
\text { cious. }\end{array}$ & $\begin{array}{l}\text { Ignorant, tried } \\
\text { to do well. }\end{array}$ & $\begin{array}{l}\text { Mother clies; father } \\
\text { puts elildren in } \\
\text { home. }\end{array}$ & 14 & Children's Home... & $\begin{array}{l}\text { In dustrious; capable with hands } \\
\text { poor in school studies. }\end{array}$ \\
\hline 78 & VI 1011 & F. & 1904 & .... Do & $\ldots \mathrm{Do}$ & ..... Do . . & 6 & .... Do. & $\begin{array}{l}\text { Now with aunt; attended school } \\
\text { but one year. }\end{array}$ \\
\hline 79 & VI 1014 & F. & 1866 & Unknown. & Harlot. & Harlot... & 19 & $\begin{array}{l}\text { Poorhouse } 1 \text { year; } \\
\text { bastard child } \\
\text { born there. }\end{array}$ & Died at 21. \\
\hline 80 & VII 38 & F. & 1892 & $\begin{array}{l}\text { Semi-industrious, } \\
\text { licentious. }\end{array}$ & $\begin{array}{l}\text { Harlot, kept bro- } \\
\text { thel (No. } 20 \\
\text { above). }\end{array}$ & $\begin{array}{l}\text { Neglected and dis- } \\
\text { orderly. }\end{array}$ & 14 & Reforinatory..... & $\begin{array}{l}\text { Settled down; married an in- } \\
\text { temperate man; has } 1 \text { child; } \\
\text { returned to prostitution; now } \\
\text { in brothcl. }\end{array}$ \\
\hline 81 & VII 40 & $\mathrm{~F}$. & 1895 & ... Do... & Do & $\begin{array}{l}\text { No home; parents } \\
\text { separated. }\end{array}$ & 9 & $\begin{array}{l}\text { Children's Home } 3 \\
\text { weeks. }\end{array}$ & Prostitute; clull in school work. \\
\hline 82 & VII 41 & F. & 1897 & ..... Do. & $\ldots$ Do & Do & 7 & $\ldots$ Do $\ldots . . . \ldots$. & $\begin{array}{l}\text { Now a prostitute; good in school } \\
\text { work. }\end{array}$ \\
\hline 83 & VII 49 & M. & 1902 & $\begin{array}{l}\text { In te mpera te, } \\
\text { semi-industri- } \\
\text { ous, tries to be } \\
\text { deeent. }\end{array}$ & $\begin{array}{l}\text { Harlot, has been } \\
\text { in penitentia- } \\
\text { rics for dis- } \\
\text { orderly con- } \\
\text { duct. }\end{array}$ & Neglected... & 7 & $\begin{array}{l}\text { Children's Home } 1 \\
\text { year; placed out } \\
\text { in Middle West. }\end{array}$ & $\begin{array}{l}\text { Retarded in school work; pleas- } \\
\text { ant disposition; good worker, } \\
\text { but witl little stamina; set } \\
\text { fre to barn at one place; at } \\
\text { another attempted to stab } \\
\text { loy. }\end{array}$ \\
\hline 84 & VII 50 & $\mathrm{~F}$. & 1904 & $\begin{array}{l}\text { Criminal, lieen- } \\
\text { tious. }\end{array}$ & .... Do. & .... Do.. & 7 & $\begin{array}{l}\text { Children's Home; } \\
\text { placed out in } \\
\text { Middle West. }\end{array}$ & $\begin{array}{l}\text { Fair work in school; hard to } \\
\text { control; inclined to be un- } \\
\text { truthful; now dead. }\end{array}$ \\
\hline 85 & VII 54 & $\mathrm{M}$. & 1897 & $\begin{array}{l}\text { Criminal, ineffi- } \\
\text { cient. }\end{array}$ & Harlot. & ..... Do. & 1 & Poorhouse....... & $\begin{array}{l}\text { Led to bcgging and stealing by } \\
\text { a relative. }\end{array}$ \\
\hline 86 & VII 88 & F. & $18 \times 7$ & Criminal. & Unknown. & ...... Do. & 10 & $\begin{array}{l}\text { C'hildren's Home } 1 \\
\text { month; then re- } \\
\text { turned to father. }\end{array}$ & Trace lost. \\
\hline 87 & V11 122 & $\mathrm{~F}$. & 1887 & $\begin{array}{l}\text { Man of no prin- } \\
\text { eiples; after } \\
\text { wife died, put } \\
\text { children in } \\
\text { home and de- } \\
\text { serted them. }\end{array}$ & $\ldots \ldots$ & $\begin{array}{l}\text { Placed in lione ly } \\
\text { father. }\end{array}$ & 9 & $\begin{array}{l}\text { C'hildren's Home; } \\
\text { placed out with } \\
\text { grandmother. }\end{array}$ & $\begin{array}{l}\text { At } 21 \text { pregnant, married; in } \\
\text { poorhouse for scveral mont lis } \\
\text { while husband searched for } \\
\text { work. Family now doing } \\
\text { well. }\end{array}$ \\
\hline 88 & VII 125 & M. & 1893 & & (1) & Po & 10 & $\begin{array}{l}\text { Children's Home; } \\
\text { placed out. }\end{array}$ & Reported doing well. \\
\hline 89 & VII 126 & M. & 1899 & .... Do. & Do & ...... Do. & 4 & $\begin{array}{l}\text { Children's Home; } \\
\text { now with older } \\
\text { sister. }\end{array}$ & Do. \\
\hline
\end{tabular}


TABLE 13.-Institutional care-Continued.

\begin{tabular}{|c|c|c|c|c|c|c|c|c|c|}
\hline \multirow{2}{*}{ No. } & \multirow{2}{*}{$\begin{array}{l}\text { Genera- } \\
\text { tion and } \\
\text { serial } \\
\text { No. }\end{array}$} & \multirow{2}{*}{ Sex. } & \multirow{2}{*}{$\begin{array}{l}\text { Date } \\
\text { of } \\
\text { birth. }\end{array}$} & \multicolumn{2}{|c|}{ Description of parents. } & \multirow{2}{*}{$\begin{array}{l}\text { Deseription of } \\
\text { individual when } \\
\text { removed to } \\
\text { institution. }\end{array}$} & \multirow{2}{*}{$\begin{array}{c}\text { Age } \\
\text { at } \\
\text { re- } \\
\text { mov- } \\
\text { al. }\end{array}$} & \multirow{2}{*}{$\begin{array}{l}\text { Institutional and } \\
\text { subsequent care. }\end{array}$} & \multirow{2}{*}{$\begin{array}{l}\text { Behavior after leaving } \\
\text { institution. }\end{array}$} \\
\hline & & & & Father. & Mother. & & & & \\
\hline 90 & VII 250 & $\mathbf{F}$ & $1 \times 96$ & $\begin{array}{l}\text { Intemperate, li- } \\
\text { centious, vi- } \\
\text { cious; No. } 44 \\
\text { above. }\end{array}$ & Harlot, ignorant. & Prostitute at II ... & $\begin{array}{l}13 \\
14\end{array}$ & $\begin{array}{l}\text { Salvation Army } \\
\text { Home. } \\
\text { House of Mercy. }\end{array}$ & $\begin{array}{l}\text { Has subsequently been arrested } \\
\text { and is now a vicious liarlot. }\end{array}$ \\
\hline 91 & VII 276 & M. & 1890 & $\begin{array}{l}\text { Industrious, but } \\
\text { licentious; fair } \\
\text { family neu- } \\
\text { tally. }\end{array}$ & $\begin{array}{l}\text { Harlot (see No. } \\
47 \text { above); in- } \\
\text { temperate. } \\
\end{array}$ & Negleeted eliild.... & 10 & $\begin{array}{l}\text { ('hildren's Home; } \\
\text { placed out in } \\
\text { West. } \\
\text {..... Do........... }\end{array}$ & $\begin{array}{l}\text { Industrious; good steady rhild; } \\
\text { now ill Midlle West. }\end{array}$ \\
\hline 93 & VII 278 & M. & 1896 & $\ldots \ldots$ Do $\ldots \ldots$ & $\ldots$. Do $\ldots \ldots$.... & $\ldots$ Do & 4 & .... Do & $\begin{array}{l}\text { Industrious, good steady clilld; } \\
\text { in Middle West. }\end{array}$ \\
\hline 94 & VII 279 & M. & 1898 & $\ldots$ Do . . . . . . & $\ldots$ Do $\ldots . . .$. & $\ldots$. Do......... & 2 & $\ldots D_{0} \ldots . . .$. & Do. \\
\hline 95 & VII 458 & F. & 1900 & $\begin{array}{l}\text { Industrious, in- } \\
\text { effieient, tuber- } \\
\text { cular. }\end{array}$ & $\begin{array}{l}\text { Industrious; after } \\
\text { husband's death } \\
\text { put ehild in } \\
\text { home; harlot } \\
\text { at one time. }\end{array}$ & Neglected. & 9 & $\begin{array}{l}\text { Children's Home; } \\
\text { plaeed out with } \\
\text { another Jukefan- } \\
\text { ily. }\end{array}$ & $\begin{array}{l}\text { Shy; eowed; industrious; does } \\
\text { not attend school. }\end{array}$ \\
\hline 96 & VII 495 & F. & 1899 & $\begin{array}{l}\text { Syphilis; lazy, in- } \\
\text { effieient. }\end{array}$ & $\begin{array}{l}\text { Harlot, ignorant, } \\
\text { syphilis. }\end{array}$ & $\ldots \ldots$ Do ......... & 11 & $\begin{array}{l}\text { Children's Home } 4 \\
\text { years; placed out. }\end{array}$ & $\begin{array}{l}\text { Industrious; in good home; dull } \\
\text { in school work. }\end{array}$ \\
\hline 97 & VII 497 & F. & 1902 & $\ldots$ Do ....... & $\ldots$ Do........ & $\ldots$ Do & $\delta$ & $\ldots$ Do ........... & Doing well in foster llome. \\
\hline 98 & VII 498 & M. & 1904 & $\ldots$ Do & $\ldots$ Do & $\ldots \ldots$ & 6 & Children's Hone... & $\begin{array}{l}\text { In institution, shy and quiet in } \\
\text { aetions. }\end{array}$ \\
\hline 99 & VII 499 & F. & 1906 & $\ldots$ Do & $\ldots \mathrm{D}$ & $\ldots . .1$ & 4 & $\ldots \mathrm{D}$ & Now in Home. \\
\hline 100 & VII 500 & F. & 1908 & $\ldots$ Do & $\ldots \mathrm{D}$ & $\ldots \mathrm{D}$ & 2 & $\ldots \mathrm{D}$ & Do. \\
\hline 101 & VII 504 & F. & 1895 & $\begin{array}{l}\text { Licentious, crin- } \\
\text { inal, feeble- } \\
\text { minded va- } \\
\text { grant. }\end{array}$ & $\begin{array}{l}\text { Feeble-min d ed } \\
\text { harlot. }\end{array}$ & $\begin{array}{l}\text { Neglected and fee- } \\
\text { ble-minded; pros- } \\
\text { titute. }\end{array}$ & -18 & Reformatory.. & $\begin{array}{l}\text { Found to be feeble-minded and } \\
\text { sent to Custodial Asylum } \\
\text { for life. }\end{array}$ \\
\hline 102 & VII 608 & M. & 1899 & $\begin{array}{l}\text { Industrious, died } \\
\text { of tubereulosis. }\end{array}$ & $\begin{array}{l}\text { Semi-e ffi e i ent, } \\
\text { shiftless. }\end{array}$ & Neglected........ & 13 & $\begin{array}{l}\text { Tubereulosis Hos- } \\
\text { pital. }\end{array}$ & Returned to mother as eured. \\
\hline 103 & VII 609 & F. & 1902 & $\ldots$ Do $\ldots \ldots$ & $\ldots$ Do $\ldots . .$. & ..... Do & 10 & $\begin{array}{l}\text { State Epileptie In- } \\
\text { stitution. }\end{array}$ & Epilepsy. \\
\hline 104 & VII 611 & M. & 1904 & $\ldots$ Do ....... & $\ldots . . . . .$. & $\ldots$ Do ......... & 8 & $\begin{array}{l}\text { Childien's Home; } \\
\text { plaeed out in } \\
\text { Middle West. }\end{array}$ & Doing well; physieally weak. \\
\hline 105 & VII 612 & F. & 1907 & $\ldots$ Do $\ldots \ldots$. & $\ldots$ Do $\ldots . . .$. & $\ldots$ Do . ........ & 5 & Children's Home... & $\begin{array}{l}\text { Returned to mother; neuro- } \\
\text { pathic. }\end{array}$ \\
\hline 106 & VII 732 & M. & 1897 & $\begin{array}{l}\text { Industrious, li- } \\
\text { eentious, fair } \\
\text { mell tality; } \\
\text { ugly disposi- } \\
\text { tion. }\end{array}$ & $\begin{array}{l}\text { Weak-willed; in- } \\
\text { dustrious but } \\
\text { ineffieient; lus- } \\
\text { band deserted } \\
\text { her and she } \\
\text { went with chil- } \\
\text { dren to Chil- } \\
\text { dren's Home. }\end{array}$ & $\begin{array}{l}\text { No home; with } \\
\text { mother to ('hil- } \\
\text { dren's Home. }\end{array}$ & 11 & $\begin{array}{l}\text { Children's Home } 1 \\
\text { year. }\end{array}$ & Did well in school; now a laborer. \\
\hline 107 & VII 733 & F. & 1899 & $\ldots$ Do....... & $\ldots$ Do $\ldots . .$. & $\ldots \mathrm{D}_{0} \ldots$ & 9 & $\begin{array}{l}\text { One Children's } \\
\text { Home, then trans- } \\
\text { ferred to another. }\end{array}$ & Average in sehool work; neat. \\
\hline 108 & VII 736 & F. & 1901 & $\ldots$ Do . . . . . & $\ldots$ Do $\ldots . . .$. & $\ldots$ Do . . . . & 7 & $\begin{array}{l}\text { Children's Home } 2 \\
\text { years. }\end{array}$ & Do. \\
\hline 109 & VII 737 & M. & 1903 & $\ldots$ Do . . . . . . . & $\ldots$ Do ........ & $\ldots$ Do .... & 5 & $\ldots$ Do ................. & Do. \\
\hline $11 I$ & VII 780 & F. & 1905 & $\begin{array}{l}\begin{array}{l}\text { Fair intelligenee; } \\
\text { dead. }\end{array} \\
\ldots \text {. . Do . . . . . . . }\end{array}$ & $\begin{array}{l}\text { Prostitute, inef- } \\
\text { fici en t, lazy, } \\
\text { vicious. } \\
\ldots \text {. . Do ........ }\end{array}$ & $\begin{array}{l}\text { Wild, negleeted } \\
\text { child. } \\
\ldots \text {.... Do......... }\end{array}$ & 8 & C'hildren's Home... & Feelsle-ninded. \\
\hline 112 & VII 787 & F. & 1899 & $\begin{array}{l}\text { Lieentious, inef- } \\
\text { ficient. }\end{array}$ & $\begin{array}{l}\text { Harlot, semi-in- } \\
\text { dustrious, shrew. }\end{array}$ & Prostitute....... & 15 & Reformatory ...... & Now in Reformatory. \\
\hline 113 & VII 835 & M. & 1884 & Unknown...... & Harlot......... & $\ldots \ldots \ldots$ & 1 & Poorhouse........ & Dead. \\
\hline 114 & VIII 17 & F. & 1905 & $\begin{array}{l}\text { Ineffieient, aleo- } \\
\text { holic. }\end{array}$ & .... Do. & Negleeted... & 6 & $\begin{array}{l}\text { Children's Home; } \\
\text { plaeed out in } \\
\text { Middle West. }\end{array}$ & $\begin{array}{l}\text { Neat, quiet-appearing child; } \\
\text { tests her age by Binet Test, } \\
\text { lout is retarded in school work. }\end{array}$ \\
\hline 115 & VIII 18 & M. & 1908 & $\ldots$ Do. & $\ldots . . . D_{0}$ & .... Do. & 3 & $\ldots$ Do ........... & $\begin{array}{l}\text { Neat, attractive child; grade } 1 \\
\text { in school. }\end{array}$ \\
\hline 116 & VIII 19 & F. & 1909 & $\ldots$ Do ... & $\ldots . . D_{0} \ldots . .$. & $\ldots . . \mathrm{D}_{0} \ldots$ & 2 & $\ldots D_{0} \ldots \ldots$ & Neat-appearing ehild. \\
\hline 117 & VIII 54 & F. & 1905 & Unknown... & $\begin{array}{l}\text { Harlot, feeble- } \\
\text { minded. }\end{array}$ & No home. & 6 & .... Do.. & $\begin{array}{l}\text { Has syphilis; ill-mannered; fond } \\
\text { of dress; slow mentally. }\end{array}$ \\
\hline 118 & VIII 60 & F. & 1908 & Industrious. . & $\begin{array}{l}\text { Pregnant before } \\
\text { marriage; is } \\
\text { No. } 87 \text { above. }\end{array}$ & $\ldots$ Do. & 1 & Poorhouse 3 months & Now with parents. \\
\hline
\end{tabular}


Summary of lable 13.

\begin{tabular}{|c|c|c|c|c|}
\hline & $\begin{array}{l}\text { Doing } \\
\text { well. }\end{array}$ & $\begin{array}{c}\text { Doing } \\
\text { poorly. }\end{array}$ & $\begin{array}{c}\text { Died } \\
\text { under } 21\end{array}$ & $\begin{array}{l}\text { Trace } \\
\text { lost. }\end{array}$ \\
\hline Alnshouse............... & 3 & 21 & 3 & 3 \\
\hline Children's institutions (not penal).. & 21 & 14 & 2 & 9 \\
\hline 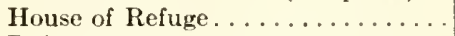 & 1 & 13 & 1 & . \\
\hline 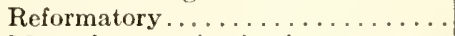 & $\cdots$ & 3 & . & . \\
\hline More than one institution..... & 2 & 9 & .. & 4 \\
\hline 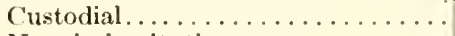 & $\cdots$ & 3 & . & . \\
\hline Now in institutions.............. & 3 & 3 & . & . \\
\hline Total. & 30 & 66 & 6 & 16 \\
\hline
\end{tabular}

Cases 47 and 48 , table 13 , are two sisters. The first was in the almshouse at 19 , where her first child was born; she is now a harlot. The second was in the House of Refuge for one year for disorderly conduct, then placed out, soon married and had children; she is now a harlot at times. Two brothers of these sisters have never been in institutions. One is an intemperate, semi-industrious, licentious laborer. The other, an actor, married a good womall and had several children by her. He is unfaithful to her and wishes to divorce her that he may marry his paramour. The inherent, strong sexual activity in each one of the fraternity crops out in spite of institutional care and training.

No. 80 was in a reformatory at 14 years of age for prostitution. She did well for a while after leaving the institution and then married, but her husband spent all his earnings in drink. She went with her small baby to the poormaster, who could do nothing to prevent her husband's drinking, and soon after this she became a prostitute and lived in a house of prostitution. The institutional care failed to permanently improve her, but intelligent aftercare by the institution might have prevented this relapse. All of her sisters, including the two who were in a Children's Home for three weeks, are now prostitutes.

The institution, then, does not permanently improve the condition of some. These react aftelwards in society, as their sibs do who have not been in institutions. These have not inherited and so do not possess the potential traits which others can work upon and train. On the other hand, as has been stated above, many are helped and improved by the institutional care and training. These individuals have a better inheritance and set of traits to develop and their better response to the new environment is due to the possession of those traits which can be molded and shaped by proper contact with. others, so that in society they become good citizens.

\section{Penal Institutions.}

There have been in penal institutions 118 Jukes and 53 of " $\mathrm{X}$ " blood. These include commitments to jail, reformatories, penitentiaries, and State prisons. The conclusion has been drawn in the section on crime that the Juke criminality is the result of feeble-mindedness and that therefore the individual should not be "punished," but should be placed in such custodial care that, while earning a living and supporting his parents or family, he can not be allowed to reproduce his subnormal mentality. While incarceration has very seldom caused the termination of a criminal career in the Jukes, there are a few cases where penal servitude seems to have accomplished its purpose. Adelbert, V 49, was considered reformed after his first State-prison experience following a jail conviction. At the age of 19, VI 236 (whose father committed murder while intoxicated) committed an assault while drunk and was sent to jail for $\mathbf{5}$ days; since that time he has never been intoxicated or arrested and is now a good citizen. No other clearly defined cases of reformation following imprisonment are to be found in the Jukes; and it is, of course, uncertain whether these persons would have continued their conduct in the absence of incarceration.

The many members of this family who have served terms in penal institutions have looked upon their enforced stay not as punishment for the deed done but merely as an incident to the fact that they were caught and to them their conviction had little to do with their criminal career. The uselessness of penal servitude for feeble-minded men and women and the necessity for custodial care continually impressed the investigator while studying the Jukes. The most striking example of this is Willett, who, so feebleminded as to be easily recognized, was sent to State prison for 8 years for arson and burglary, later to jail for assault and battery, and yet finally murdered a man and was then hanged. Custodial care beginning with his first conviction would have been better not only for him but for society as well. The real pathos of the lives of VI 151 and VI 152 will never be appreciated by those who have had a normal childhood of play and work. The father of these two feeble-minded boys was in and out of State prison during their early childhood and their mother lived with another man while the boys were adolescent. Almost the whole life of one was spent in institutions. He died at 27 years of tuberculosis in State prison, the disease probably being acquired in the prison. The other was sent to a reform school at 11. He was discharged after being in the institution 6 years, but was returned the following year as incorrigible. He then committed the crime, setting fire to the buildings and trying to escape, which sent him to State prison, where he, too, died of tuberculosis. If these two children had been in a custodial asylum, as their mentality indicates they should have been, they could at least have been made self-supporting under supervision, and the great cost to the State of their crimes would have been lessened.

Penal servitude as a cure for crime in the Juke family seems to have been a failure, as a feeble-minded person can not be made normal through any sort of punishment. 


\section{INSANITY.}

Only four cases of insanity have been found among the Jukes. In comparison with the general population of the State of New York, where all the insane Jukes live, there is less insanity among the Jukes pro rata than in the whole population. There is approximately 1 insane person to every 300 of the population in the State at large, while, among the Jukes there is only 1 to 500 , or 1 to 400 , if the Jukes who died in infancy are deducted from the total. The cases of insanity are scattered among the Jukes and no data as to the causes of each particular case have appeared, except as noted in table 14 .

TABle 14.-Insanity.

\begin{tabular}{|c|c|c|c|}
\hline $\begin{array}{l}\text { Num- } \\
\text { ber. }\end{array}$ & History. & $\begin{array}{l}\text { Institutional } \\
\text { care. }\end{array}$ & Results. \\
\hline IV 35 & $\begin{array}{l}\text { Insane tendency for } \\
\text { many years. }\end{array}$ & None..... & At 41 , suicide. \\
\hline IV 146 & Alcoholic psychosis..... & $\begin{array}{l}\text { At } 67 \text {, hospital, } \\
3 \text { months. }\end{array}$ & Died in hospital. \\
\hline V 1 & $\begin{array}{l}\text { At } 60 \text {, delusional, follow- } \\
\text { ing alcoholism. }\end{array}$ & $\begin{array}{l}\text { At } 60 \text {, hospital } \\
\text { for insane. }\end{array}$ & Do. \\
\hline VI_157 & $\begin{array}{l}\text { Uterine trouble, causing } \\
\text { mental disturbancc. }\end{array}$ & $\begin{array}{l}\text { At } 29 \text {, hospital, } \\
\text { for insane } 2 \\
\text { months, sui- } \\
\text { cidal and hom- } \\
\text { icidal. }\end{array}$ & $\begin{array}{l}\text { Recovery from } \\
\text { attack. }\end{array}$ \\
\hline
\end{tabular}

\section{EPILEPSY.}

Nine cases of epilepsy are recorded among the Jukes. As no survey of New York State has been made for the frequency of this disease in the population it is impossible to make a comparison between the amount of epilepsy

Gen.

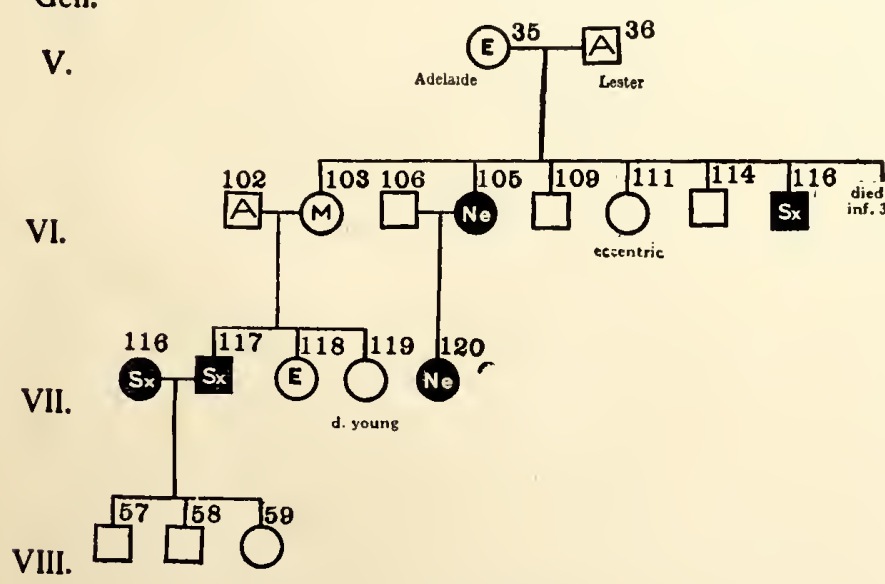

Chart 28.-Epilepsy.

E, epileptic. A, alcoholic. $\begin{gathered}\text { M, migrainous. Sx, licentious. } \\ \text { Ne, neurotic. }\end{gathered}$ in this group and in the general population. In New Jersey a partial survey indicates 1 epileptic to every 1,100 of the population. The proportion in the Jukes is 1 epileptic to every 230 . Of these cases 7 are scattered, while 2 are closely related, being grandmother and granddaughter. This case is shown in chart 28. The mating of epilepsy in Adelaide and of alcoholism in Lester produced 1 female with migraine, 1 neurotic and now addicted to drugs, 1 ecentric, 3 persons with no nervous affections, and 3 dead. The first of these, VI 103, with severe migraine, married an alcoholic and produced 1 epileptic, VII 118; 1 sex offender, VII 117, and 1 who died in infancy. Here the epilepsy is clearly inherited. On one side of the ancestry is a neuropathic strain, on the other, alcoholism.

TABLe 15.-Epilepsy.

\begin{tabular}{|c|c|c|c|}
\hline Number. & History. & $\begin{array}{l}\text { Institutional } \\
\text { eare. }\end{array}$ & Result. \\
\hline VII 118 & $\begin{array}{l}\text { Developed in early life, } \\
\text { with marked mental } \\
\text { deterioration. Excit- } \\
\text { able and delusional. }\end{array}$ & $\begin{array}{l}\text { At } 17 \text {, hos- } \\
\text { pital for in- } \\
\text { sane. }\end{array}$ & $\begin{array}{l}\text { Died at } 31 \text { in } \\
\text { hospital. }\end{array}$ \\
\hline VII 179 & Fainting spells as a child. & None........ & "Outgrew them." \\
\hline VII 645 & Epilepsy all life... & . Do . . & $\begin{array}{l}\text { At } 32 \text {, has spells } \\
\text { frequently. }\end{array}$ \\
\hline VII 609 & Developed when young. . & $\begin{array}{l}\text { At } 12 \text {, institu- } \\
\text { tion for epi- } \\
\text { leptics. }\end{array}$ & No change. \\
\hline VIII 40 & .... Do . & None........ & $\begin{array}{l}\text { Becoming deter- } \\
\text { iorated. }\end{array}$ \\
\hline V 35 & 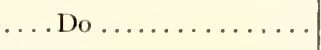 & . Do... & Died. \\
\hline VII 647 & $\begin{array}{l}\text { Died at age of } 17 \text { months; } \\
\text { sister of VII } 645 .\end{array}$ & ..Do... & Do. \\
\hline IV 165 & "Acquired"........ & ... Do.. & $\begin{array}{l}\text { Died in epileptic } \\
\text { convulsion. }\end{array}$ \\
\hline V 395 & No history known. & . Do. & Do. \\
\hline
\end{tabular}

\section{EUGENIC MATINGS.}

A rough classification of the 399 fertile marriages anong the Jukes gives 176 eugenic matings and 223 cacogenic matings. In the opinion of the writer, who has studied the people and their offspring, 55 per cent of the matings are detrimental to the forward progress of the Juke family, while 45 per cent may be considered eugenic or beneficial. The standard of a eugenic mating has been put low, as it is desired to give everyone the benefit of the effect of environment. Had these cacogenic matings been forbidden or if offspring had been prevented by sterilization, it is safe to say that in the next generation less than 5 per cent of the whole offspring would have shown undesirable traits. As it is now, with unrestricted reproduction, over half the offspring either is mentally defective or has anti-social traits. 


\section{SOCIAL DAMAGE.}

Dugdale estimated a loss to society of $\$ 1,250,000$ by the Juke family from 1800 to 1875 , not including the drink bill. The loss to society caused by mental deficiency, crime, prostitution, syphilis, and pauperism of these 2,800 people is estimated now at $\$ 2,093,685$. If the drink bill is added, this total becomes $\$ 2,516,685$. It is estimated that $\$ 648,000$ of pension money has been paid to the Jukes. Much, if not most of this, has been spent for whisky and the rest has furnished support which in most cases would otherwise have been furnished by pauper relief.

To counterbalance this cost, the earnings of V 106, VI 89 , and VI 140 total $\$ 160,000$, and some of the other Jukes are self-supporting, but the earning power of the few ind ustrious Jukes can not overbalance this deficit to society.

TABLE 16.-Financial estimate of cost of Jukes to society. (Statement modeled after that of Dugdale, for comparison with his.)

Total number of persons. 2,820

Number of pauperized adults 366

Cost of almshouse relief, $\$ 150$ per year Cost of outdoor relief.

Number of criminals.................

Years of imprisonment.........

Cost of maintenance, at $\$ 200$ per year. Cost of Willett-Lillie murder

Number of arrests and trials. Cost, $\$ 100$ each .

$\$ 70,200$ ${ }^{1} 13,510$

75,000

13,000

300

Number of habitual thieves.

30,000

Number of years of depredation, at 12 years each.... Cost, at $\$ 120$ per year

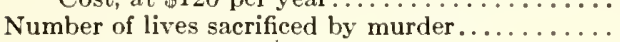
Valuc, $\$ 1,200$ each

Number of prostitutes ................

A verage number of years of debauch.......... 15

Total number of years of debauch.......... 2, 625

Cost of maintenance, at $\$ 300$ each per year.

625

Number of women specifically diseased.

55

Average number of men each woman contaminatcd with permanent disease.

10

Total men contaminated.................. $\quad 550$

Wives contaminated by above men.

55

Total number of persons contaminated

660

Cost of treatment rest of life, $\$ 50$ each

Loss of wages by 550 men, 3 years each. . . . . . 1,650

Loss, at $\$ 400$ per year.

Total number of years lost from productive industry by courtesans, 5 years each

Loss, at $\$ 125$ per year.

Loss in curtailment of life of 660 people, equivalent to 65 people, at $\$ 1,200 \ldots$

Aggregate of children who died prematurely ..... 378

Cash cost, $\$ 50$ cach child.

Number of prosecutions in bastardy

Cost, at $\$ 100$ each.

Cost of property destroycd in brawls

Capital in brothcls.

Compound interest, 26 years, at 6 per cent...

Charity distributed by church

Charity obtained by begging.

$$
\text { Total. }
$$

Drink hill, 282 intemperate, losing an averagc of $\$ 50$ per ycar for 30 years. .

Grand total

875

115,200

12,000

787,500

33,000

660,000

109,375

78,000

18,900

4,000

20,000

6,000

18,000

20,000

10,000

$2,093,685$

423,000

$2,516,685$

Note: Pension money paid to Jukes as ('ivil War soldiers or

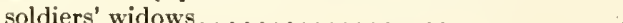

Note: Total earnings of 3 productive Jukes:

Earnings of V $106 \ldots \ldots \ldots \ldots \ldots \ldots \ldots \ldots \$ 100,000$

Earnings of VI $140 \ldots \ldots \ldots \ldots \ldots \ldots \ldots 10,000$

Earnings of VI $89 \ldots \ldots \ldots \ldots \ldots \ldots \ldots . \quad 50,000$

Total earnings of 3 well-to-do Jukes............................

${ }^{1}$ This figure is based on estimate of Dugdale on page 29.
XXIII. CONDITIONS UNDER WHICH IMPROVED INDIVIDUALS OR STRAINS OF JUKES HAVE ARISEN.

\author{
Case 1, Hannibal, V 106.
}

Maternal side.-The mother was a Juke, Augusta, IV 17, an ignorant but hard-working woman described by Dugdale in the words: "Constitutional syphilis; at 30 , o. relief, 3 y.; husband dies; 34, charges bastardy on her cousin who married her; girl born; 41, o. relief, 1 y." Augusta was one of a fraternity of 8 described by Dugdale; all had syphilis; four other sisters were harlots, 1 an idliot, and 1 bore a good reputation. The only brother was a laborer and temperate. Their father, in turn, was indolent and licentious in youth, but their mother bore a good reputation and was from the best of the Juke sisters. We see that there are some good individuals in this branch of the family - some good traits to be inherited.

Paternal side.-Hezekiah, IV 16, had consumption and died from this disease, as a pauper, at the age of 40 years. Nothing at all is known about his genctic tendencies; he was apparently not of Juke blood; this was therefore an out-marriage of the type that has generally conferred strength upon offspring.

Fraternity.-The propositus had a sister Nanchia, $\mathrm{V} 108$, to whom fell the bad inheritance. She was a harlot, acquired syphilis, and had 2 illegitimate children, both of whom died; she was a waitress in a hotel.

Environment.-The parents were both poor and received outdoor relief. Whilc yct young, Hannibal was placed with a good family in the Juke region and learned the blacksmith trade.

Traits.-Hannibal early showed an aptness for dickering, served through the Civil War, became an actor and was highly successful, but later became financially embarrassed and committed suicide at the age of 64 , having feared, it is said, to take an anesthetic for an operation on an injured wrist.

Comment.-There is an unfortunate absence of knowledge as to hereditary traits and, consequently, this case can not bc used to support an argument that good environment has transformed a Juke into a successful actor. It is clear that at an early age the boy showed uncommon brightness and shrewdness. No doubt the good home helped him to use his capacities. These capacities, by the way, were rather of the emotional than of the intellectual type.

\section{Case 2, VI 140.}

Maternal side.-The mother, Amalia, V 39, "had brains enough, but used them in the wrong way." She was ignorant and intemperate, and for many years a harlot. Of her sibs, 3 sisters were harlots and 1 temperate but indigent; of the 3 brothers 2 werc Juke-like but 1 was a carpenter, could read and write, and was a good, industrious citizen. The mother of this sibship was a somewhat industrious, temperate woman who became a prostitute while her husband (of outside blood) was in the State prison. This husband had some education, was formerly intemperate, and at 30 years served 2 years in State prison for forgery. 
Paternal side-The father, Douglas, IV 131, was a Juke, descended from Delia-an ignorant, licentious, inefficient man who killed his brother in a drunken brawl. There were 8 in this sibship, one at least temperate, the others ignorant, mostly mentally deficient and licentiousnot a good lot. Their parents were apparently licentious paupers.

Fraternity.-The first child, VI 136, who has left the Juke region, becane a locomotive engineer, is married, and is a good citizen. The next, who has always been industrious and reputable, now occupies a responsible position with a manufacturing firm, and has two satisfactory children. The third, VI 140, is persevering and energetic; he has developed a good business and accumulated property. His business was almost destroyed by fire one Sunday morning, but early the following day he hired horses to replace his burned ones and was engaged in business as usual. However, all three of his children were born before he married their mother. That mother is intelligent but shrewish. All three of the children are inclustrious: one, at 35 , holds a responsible position as bookkeeper in a large corporation; one is quite musical but intemperate; and the third is an intelligent woman of good repute, formerly a school-teacher, now well married. The fourth member of the main fraternity is a woman, VI 142, of fair intelligence and good repute. She is married and has four children who seem to be turning out well.

Comment.-In this case both parents, though anti-social themselves, brought in some strength. The mother was, herself, intelligent (like her father) and had a brother who was a good, industrious, intelligent citizen. One of the father's brothers was temperate. Two of the three children were apparently brought up in the Juke environment; one lived for some years in common-law relations with a woman whom he eventually married, but otherwise they all seem to have behaved well. One brother left the Juke region and, like those who remained, is a good citizen. It is difficult to explain the origin of this good branch on the ground of environment only. We should expect some antisocial children; it is probably only a fortunate chance that all three received only the determiners of industry and intelligence.

\section{Case 3, Evander, V 421.}

Maternal side.-The mother, Flossie, was a deaf and dumb woman, of whose connections nothing is known.

Paternal side.-The father, Elias, IV 167, was an habitual drunkard and a pauper. He was twice arrested, once for assault and battery and once for disorderly conduct. Three of his four sisters were harlots; all his brothers spent time in jail, but his sister Ella bore a good reputation.

Environment.-The father and family wandered about the country a great deal, rarely settling long in one place.

Evander, $V$ 421.-At 19 not industrious, he later gained some ambition and property and was always temperate. He married an industrious, reputable but brusque woman. One son now holds a responsible position on a railroad; the next child, a girl, did average work at school, is chaste, and works in a factory; the next boy is less active physically and mentally, but does fairly well; the next could not ro high-school work; the last is slow mentally, stubborn, and sullen at times.

Sibs.-(1), female, environment apparently the same as for her brother, not inclustrious, and a harlot; was literate, but acquired no property.

(2), female, a hallot before marriage; married first a thriftless man; second, an intemperate man. None of the chilclren is wholly satisfactory, although industry, intelligence, and chastity are found among them, but usually not combined in the same individual.

(3), male, a brickmaker by trade, who works steadily for a few days and then spends his wages for drink. By an industrious and controlled cousin of Delia blood he has 5 children who seem mentally capable, but physically inert.

(4), female, a harlot before marriage, has clone fairly well since; has 8 children, all of whom are fairly industrious and none strictly feeble-minded.

(5), male, a wanderer, who served 4 months in the penitentiary for petit larceny and was sentenced for 10 years because of rape.

(6), male, feeble-minded, semi-industrious, has served several jail terms.

Comment.-All of these sibs were brought up under practically the same environment, but their heredity was very different. This difference of heredity is probably the real differential that causes the dissimilar reactions to that environment.

\section{CAsE 4, VI 603.}

Industrious and intelligent, has four children, of whom the eldest holds a responsible position with a business firm, the second is a refined girl of 16 doing good work in the high school, and the two youngest are doing good work in the grades.

Maternal side.-The mother, Beulah, V 244, was a woman of good repute, industrious, temperate, literate, and well controlled; one of her sisters was blind, the other a harlot. One of her brothers was industrious like herself and one was not. Their mother, Bessie, IV 72, who was a harlot after marriage, is saicl to have been "intelligent, with excellent memory." She married a cousin, a poor man who was temperate.

Paternal side.-The father, Fred, V 243, was a laborer, temperate and literate; he inherited property and was a good citizen. Of French extraction, he brought good traits into the Juke strain.

Sibs of propositus.-All seven, save one, or perhaps two, are quite up to the average of unskilled laborers.

$$
\text { Case 5, VI } 119 \text { and VI } 126 .
$$

VI 119, male, is an industrious, thrifty mechanic of good reputation. He went to New York City. His brother, VI 126, followed his example; he is a steady, industrious man who married a careful, industrious, capable girl and has a family which is quite up to the average. Now, did these brothers show more ambition and industry because they went to the city, or did they go to the city 
because they were inherently ambitious and industrious? Let us look at their family traits.

Maternal side.-The mother, Annetta, V 37, had little education and drank, but was of fair intelligence. All of her sisters, so far as known, were harlots, but not she. One of her brothers was a carpenter, industrious, literate, and a good citizen; another, though illiterate, was industrious. The mother's mother was somewhat industrious.

Paternal side.-The father was an industrious but unskilled man, self-controlled, but ignorant and consequently rather inefficient. He is of outside blood.

Sibs of proposituses. (1), female, chaste, intelligent, and reputable; married well. (2), female, married poorly; her husband deserted her; she has moved with her son to New York, but the son is shiftless. (3), male, remained in the Juke region; is a laborer and works at whatever comes his way; he married a feeble-minded woman and three of his four children are retarded at school.

Comment.-We have difficulty in ascribing the differences of the sibs to environment, since the eldest sister has clone well at home; those that left their native environment and were successful were probably already different from those who remained behind; their success depended upon the fact that they got into an environment where they could make good use of the best that was in them.

\section{Case 6, Fraternity of VI 438.}

(1), female, VI 438, did average work in school, became a clandestine prostitute, was married at 17 to a man of ambition, and now makes a good, capable wife. Of their 5 surviving children 2 are well married, 2 are still in school and, though mentally slow, are doing fair work, and 1 is still young.

(2), male, though a good worker is restless and has never accumulated anything; of his 3 children 1 is a typical street tough, 1 is rather quiet and honest, and the third is between the other two.

(3), female, capable in school, a harlot before marriage; now married, is industrious, neat and of good repute, and has a number of good children.

(4), male, is an energetic, upright, traveling salesman, who has a well-behaved, capable daughter.

(5), male, steady but not as smart as the others.

(6), male, resembles the old Jukes in behavior, is intemperate, nomadic, and semi-industrious.

Maternal side.-Sarah, the mother, has a defective make-up, is at times intemperate, and is inefficient and not industrious. Sarah's mother was a harlot after marriage.

Paternal side.-Franklin, V 170, has always been a steady worker, but he puts the money he earns into wildcat schemes and, as a result, is very poor. He is temperate and bears a fair reputation in the community.

Environment.-Soon after marriage Franklin and Sarah removed from the Juke region to a small manufacturing city in a neighboring State, and there they have continued to live.

Comment.-The better environment enabled these children who "had it in them" to show "what they were made of." Three turned out well and three turned out ill.
Probably those who turned out well would not have done so well had they remained in the old environment; quite certainly they would not have married so well and their children would have been inferior.

\section{Case 7. Fraternity of VI 504.}

(1), female, VI 504, is somewhat reticent, but holds herself well; is married to an artisan and has an accurate, careful, though slow, child of 14 years.

(2), male, slipshod, but regular in his work, did well by his family; his 2 small children are doing very well in school.

(3), female, more active and forward than No. 1; married a prosperous farmer and has 3 children of good mental ability.

(4), male, an uneducated, steady-going farm-hand, who is doing well.

(5), female, is mentally and physically active.

Paternal side.-Reuben, V 193, a great-grandson of Ada Juke, was mentally dull and slow at school, is a farm laborer, and has never been able to keep a position any length of time; he has wandered here and there to secure work and has never accumulated anything; is quiet and retiring. At least two of his sisters were harlots and one of his brothers was criminal, but a sister, Hetty, shows a great deal of self-respect and has always tried to do well.

Maternal side.-Mamie, the mother, "comes from a family much higher mentally than Reuben's." Her father was a dentist, was intelligent, and bore a good reputation in the community where he lived. She is energetic, capable, and a good mother. She has two brothers who are storekeepers and one who is alcoholic.

Environment.-There is no evidence that this family was brought up in a new and superior locality. Their father wandered and he took his family about with him. The fine mother offered the best of environment for her children, even in the Juke territory, but she afforded still morean hereditary capacity for taking advantage of her training, a natural self-control sufficient to act in accordance with the mores she inculcated.

\section{Case 8, VI 459.}

Born in 1858, at 16 years she was sent to the House of Refuge for disorderly conduct and prostitution. After discharge she was placed out with a very refined family in $Z$. After this she had a bastard child. At 18 she married and has had 10 children; since her marriage she has consistently tried to do well. She has reared 8 children in the face of misfortumes that would have discouraged many another person. She is quiet in speech, neat, and refined.

Propositus has no full sibs. One half sister, who is ignorant, married an old soldier to get his pension and had 4 ineffective children. A sister of the foregoing has much better traits and is bringing up a good family. The youngest brother is a steady worker, retiring by nature.

Maternal side.-The mother is Hepsy, V 178, a Juke, of illegitimate origin and mother of a bastard child. She tramped the roads with her husband and drank heavily with him. Her sisters were mostly harlots, but one turned 
out well. The first was a hartot all her life; married and became a pauper. Another sister, Mary Jane, was a prostitute in her mother's brothel when young. She secured a common-law husband and lived with him for 40 years. A third sister, Hetty, has a great deal of self-respect and has tried always to do well. See Case 7 , paternal side.

Thus, in this family, the girls are promiscuous in early youth and some of them tend to settle down after marriage, just as VI 459 did. One can not, therefore, attribute her good behavior (after having been in a good family, and later married) merely to the influence of the good family; it depends on certain constitutional qualities such that the good ideals appealed to her and she was able to exercise that self-control that enabled her to act in accordance with the mores which she had learned in the refined family.

\section{Case 9, Una, V 360.}

Her 3 children are good in school, industrious, and refined. How did such childien arise out of the Jukes?

Maternal side.- The mother, Una, is full of wit and humor and shows so much refinement that it is hard to believe that she is a Juke. She is neat, industrious, and mentally active. She has a brother who is an unskilled laborer, but who is industrious, has accumulated property, and bears a good reputation in the neighborhood. Una's two sisters are of good repute and fair intelligence. Una is, then, merely the best of a fainly good fraternity. 'Jleir father was a Juke, a bastard child of 1)elta, who was, on the whole, chaste; he was a laborer and a pauper. He married one Persis, IV 154, an intemperate woman, apparently of out-blood, but she must have brought in strong germinal characters.

Paternal side.-The father, Una's husband, called Willis, is an intelligent, industrious fruit-grower, who with the aid of his frugal wife, has accumulated property. He is, apparently, of out-blood-nothing is known of his people, but it is clear that he brings much strength to the combination.

Environment.-There is nothing special to note. Inevitably, the intelligent mother had a better-kept home than her thriftless neighbors; but this presages more ambitious children, as it favors the development of the inborn elements of ambition.

Thus, a calın, jurlicial cxamination of the better fraternities that have come out of the Jukes justifies the conclusion that good parental blood is quite as striking a moment in the history as exceptionally good environment, but one rarely gets bad environment where the parents are healthy and intelligent. In a few cases the parents of a fine fraternity are bad, but under such circumstances both parents have sibs whose somatic qualities are uncxeeptionable. The parents carry, though they may not exhibit, potentialities for fine qualitics. 


\section{STATISTICAL SUMMARIES OF THE JUKES.}

1,258 individuals descended from the five original Juke sisters are living in 1915, as mentioned in Section XI on Population; 186 of these are under the age of 6 , the majority of whom are in average, good, moral homes, $i . e$, under good environment. It will be of value to eugenies to study these after they have reaehed maturity. 324 Jukes are between the ages of 6 and 15 . Table 17 gives a summary of the sehool ability and soeial reaetion of these individuals. The sehool reeord of 227 of these has been studied. 31 have done well in sehool, 113 are called fair. Many of the latter are slow but can acquire sehool knowledge if given time. This group does not "cateh on" as readily as the others. Their power of retention is not strong or well-developed. Some of these have adenoids, others eye defeet, and a few are deaf. However, these same defeets may be found among the bright pupils of the Juke family. This seeond group usually begins to retard in the fourth grade, spending perhaps two years of sehool time in that grade, two in the fifth, reaching the age of 16 while either in the fifth or sixth grades, when the eompulsory sehool law eeases to compel their attendance. They then drop out and the boys become untrained workmen or laborers, while the girls work at unskilled labor in either laee, shirt, eigar or similar faetories.

In "Social Reaction" the individuals are placed under three heads: 40 are active, neat, eapable and efficient and are thus elassed as "good." 128 are neat, quietaetioned, generally moral, but not so eapable or trainable as those in the first elass and are eonsidered "fair," while 41 are eareless, vieious, and untrainable youths, and these form the "poor" section. At this period in life the sehool reaction is generally the same as the soeial reaction, as a large part of a ehild's aetivity and behavior is determined by what he aequires or observes in sehool. There are 4 girls under the age of 15 who are prostitutes. There are 43 male Jukes between the ages of 15 and 18 . Out of 29 , whose histories are well known, 18 are anti-soeial, doing poorly in the world at large; 2 are eriminal, while 7 are so obviously mentally defeetive as to be noticeable to the general community. Of the 43,19 are industrious. A serutiny of the rest of table 17, ineluding all males over the age of 19 , and all females over the age of 15 , shows that 65 are elassed as good citizens; 255 as "fair" in their soeial reaction, while 305 are anti-soeial in their behavior, a detriment to society. 305 , or 43 per cent of a total of 705 in this group, are inimical to the general welfare of the community; 51 of these are prostitutes at present, while 82 others have been prostitutes at one time or another but are not now so; 41 are eriminal, and 103 are marked cases of mental defeet; 83 are intemperate; 152 are industrious.

This table is presented to show the character and present behavior of the Jukes who are now living.

TABLE 17.-Summary table of Jukes living in 1915.

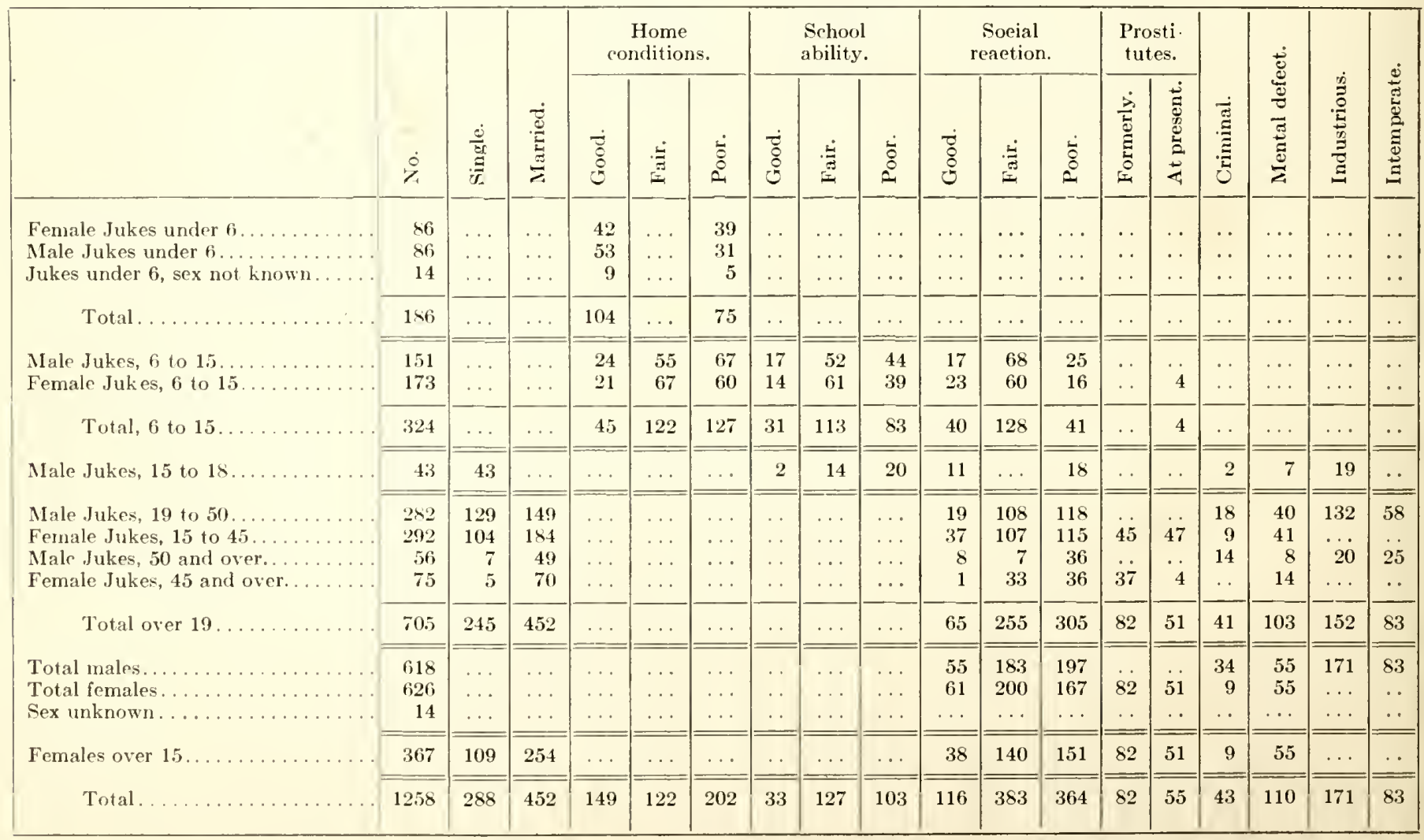


Table 18 is a statistical summary of the Jukes from the beginning to 1915 , and is comparable in part to table XI of Dugdale. Approximately four times as many persons are considered in this table as in that of Dugdale. Data on intemperance, social behavior, school ability, mental deficiency, deaths in infancy, and pensions received have been added to show the condition of the Jukes since generation IV. The data on intemperance has been discussed on page 63.296 Jukes have done well socially while 285 have done poorly. The criterion for classifica- tion has been the opinion of the general community in which each Juke lived. This total may seem to be only a small part of the whole number of Jukes, but it nust be recalled in considering all these statistics that not all of the 2,094 known Jukes reached maturity. When the eugenic traits in the individual outweigh the had traits he is classed as "doing well." Those whose social response" is poor or contrary to the "mores" are the "dloing poorly." However, in a study of this sort, not all persons fit exactly into one of the two divisions. These doubtful cases are

TABre 18.-Statistical summary of Generations II to IX of the Jukes.

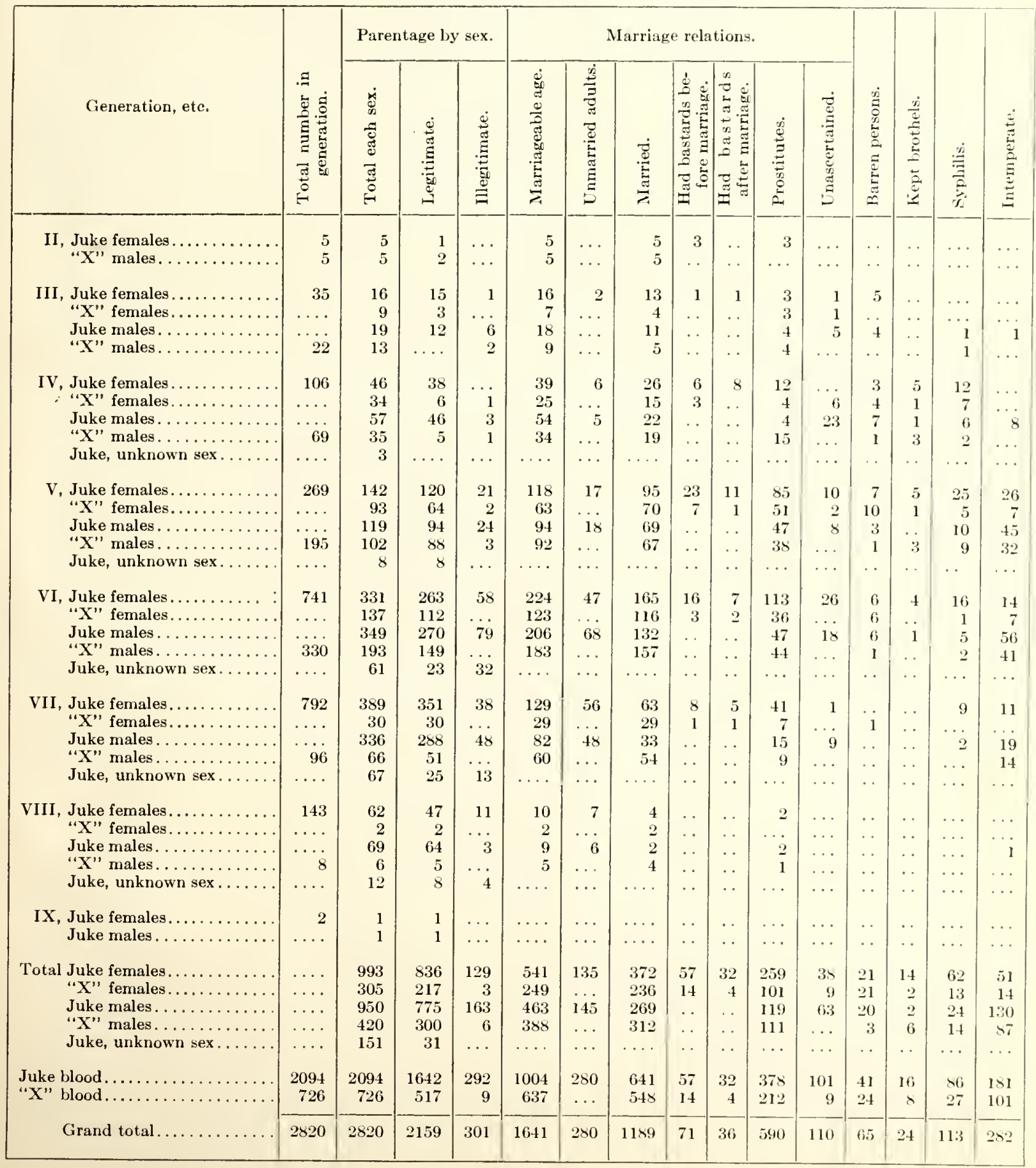


not counted. 698 Jukes have attended school, while 122 have never received any school training. 55 of the 698 have done"good" work in school, have kept up with others of their own grade, and have not been backward. 249 did "fair" work, were not as capable as the others but could "learn if given time," while 394 did "poor" work in school, were three or more years behind their grade, and were unable to profit by the school training. The drain and care of these stupid and defective children on the school system can be readily appreciated by anyone who has had experience in school matters. 107 Jukes are mentally so deficient that they are considered by the general populace as needing some sort of custodial care. 378 died under the age of 5 . This high death rate in infancy is due largely to the neglect, disease, and filthy living conditions in which many of the Jukes have lived. 18 males have received soldiers' pensions from the government. This table does not include the number of widows and children of soldiers who also have received pensions.

TABLE 18.-Statistical summary of Generations II to IX of the Jukes-Continued.

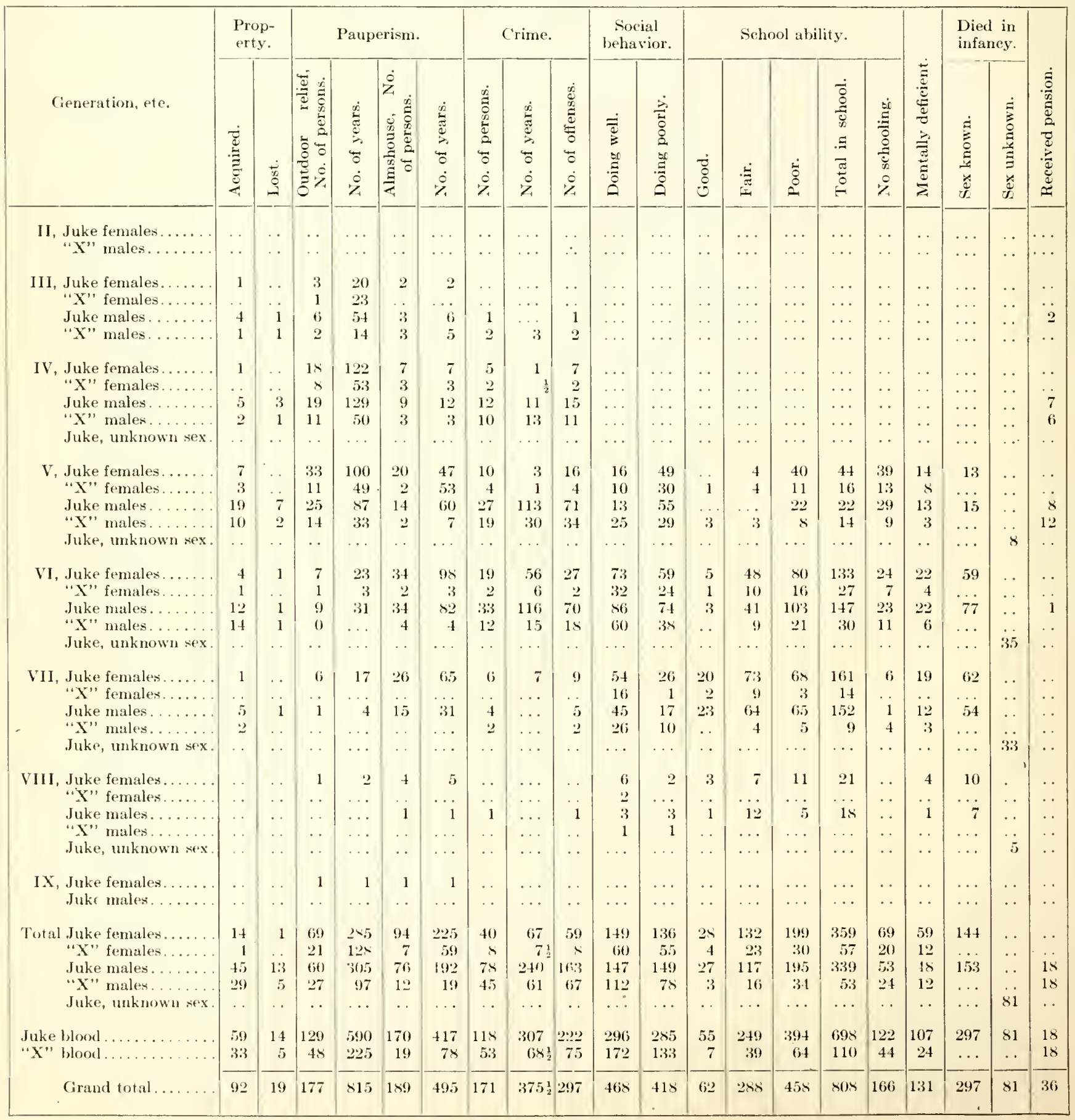




\section{GENERAL SUMMARY.}

The primary aim of this work is to present the facts of the lives of the Jukes. For the past 130 years they have increased from 5 sisters to a family which numbers 2,094 people, of whom 1,258 were living in 1915. One half of the Jukes were and are fecble-minded, mentally incapable of responding normally to the expectations of society, brought up under faulty environmental conditions which they consider normal, satisfied with the fulfillment of natural passions and desires, and with no ambition or ideals in life. The other half, perhaps normal mentally and emotionally, has become socially adequate or inadequate, depending on the chance of the individual reaching or failing to reach an environment which would mok and stimulate his inherited social traits.

There have been cited just previous to this certain cases of good citizens among the Jukes. In these men and women the bad traits which have held down their brothers and sisters have become lost and they are the fountainheads of new families of socially good strain. Heredity, whether good or bad, has its complemental factor in environment. The two determine the behavior of the individual. The social reformer and the student of eugenics must see that, no matter what the degree of perfection to which we raise the standard of environment, the response of the indivichual will still depend on its constitution and the constitution must be adequate before we can attain the perfèct indivichual, socially and eugenically.

This study demonstrates the following:

1. Cousin-matings in defective germ-plasms are undesirable, since they produce defective offspring irrespective of the parents' somatic make-up.

2. There is an hereditary factor in licentiousness, but there are those among the Jukes who are capable of meeting the requirements of the mores in sex matters if only great social pressure is brought to bear upon them.

3. Pauperism is an indication of weakness, physical or mental.

4. All of the Juke criminals were feeble-ininded, and the eradication of crime in defective stocks depends upon the elimination of mental deficiency.

5. Removal of Jukes from their original habitat to new regions is beneficial to the stock itself, as better social pres- sure is brought to bear on them and there is a chance of mating into better families.

6. One in four of the Jukes is improved socially by care in Children's Institutions.

7. Penal institutions have hittle beneficial influence upon persons of defective mentality.

The natural question which arises in the reader's mind is, "What can be done to prevent the breeding of these defectives?" Two practical solutions of this problem are apparent. One of these is the permanent eustodial care of the feeble-minded men and all feeble-minded women of childbearing age. The other is the sterilization of those whose germ-plasm contains the defects which society wishes to eliminate.

The first is practicable, since there are now many custodial institutions for the feeble-minded and epileptic and in some of these the patients are partially self-supporting. These institutions should be increased in number and capacity to receive all the defectives now at large and who must be cared for if the program of segregation is to be fully carried out. Out of approximately 600 living feeble-mincled and epileptic Jukes, there are now only 3 in custodial care. It is estimated that at the end of fifty years the defective germ-plasm would be practically eliminated by the segregation of all of the 600 .

Sterilization of those carrying epilepsy, feeble-mindedness, etc., is entirely practicable. Public sentiment, however, does not favor such a practice. ('ontrary to public belief, sterilization woukd interfere with the real liberty of the individual less than custodial care.

\section{LITERATURE CITED.}

Davenport, Charles B. 1915. The Feebly Inlibited. Carnegie Institution of Washington, Pub. No. 236.

Dugdale, R. L. 1877. The Jukes. A Study in Crime, Pauperism, Disease, and Heredity. New York and London: G. P. Putnam's Sons.

Estabrook, Arthur $H$, and Charles B. Davenport. 1912. The Nam Family. Eugenies Record ()ffice, Memoir 2. Cold Spring Harbor.

Pitnam, G. H. 1916. Memories of a Publisher (1865-1915), New York and London: G. P. Putnam's Sons.

Shepard, Edward M. 1884. The Work of a Social Teacher. New York. 





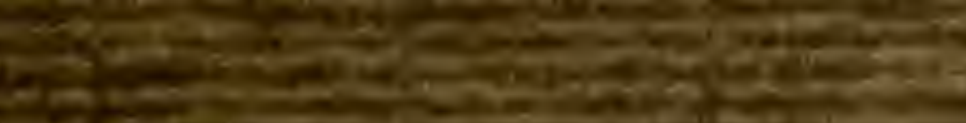

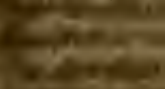

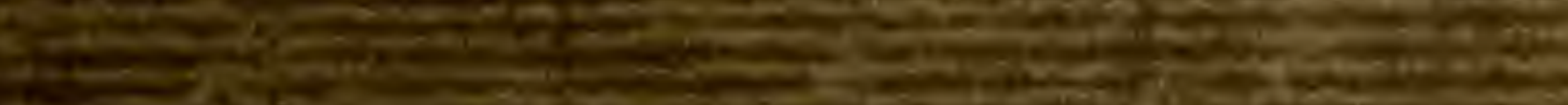

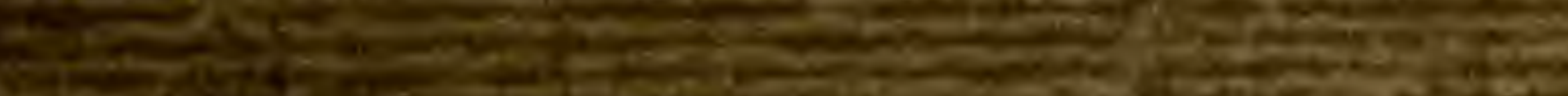
$=$

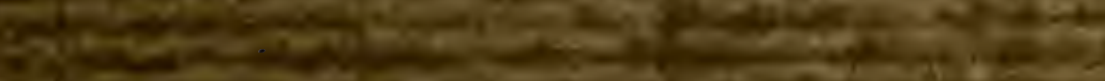

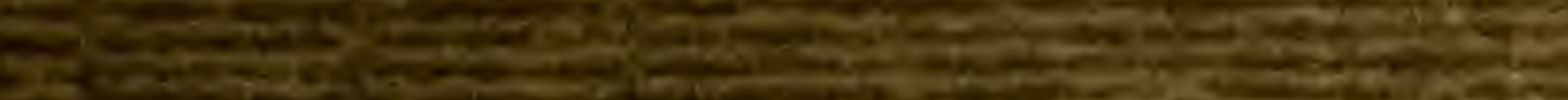

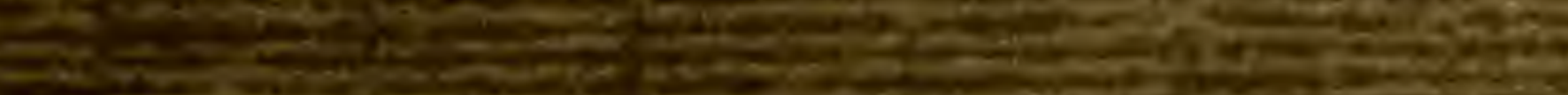

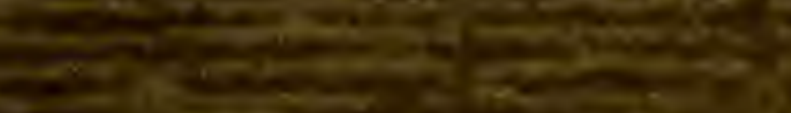

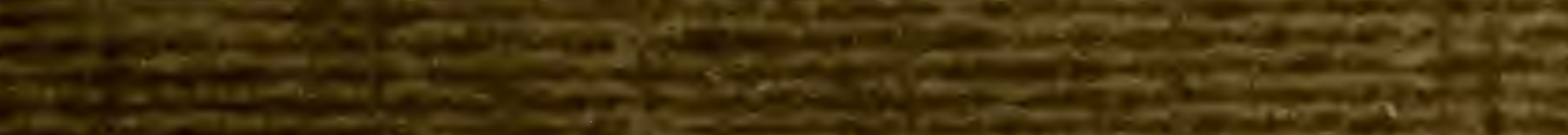

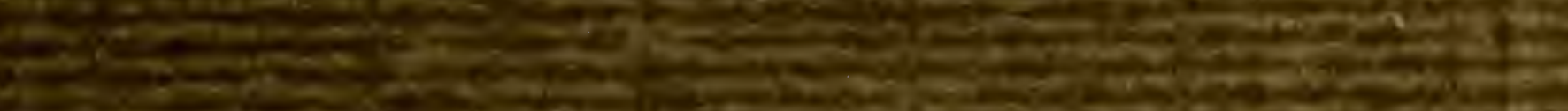

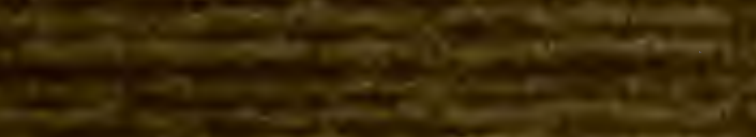

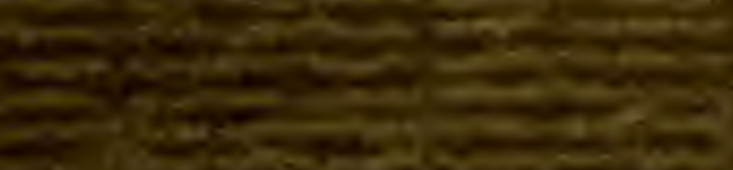

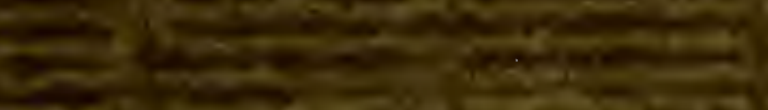
$x^{2}=$

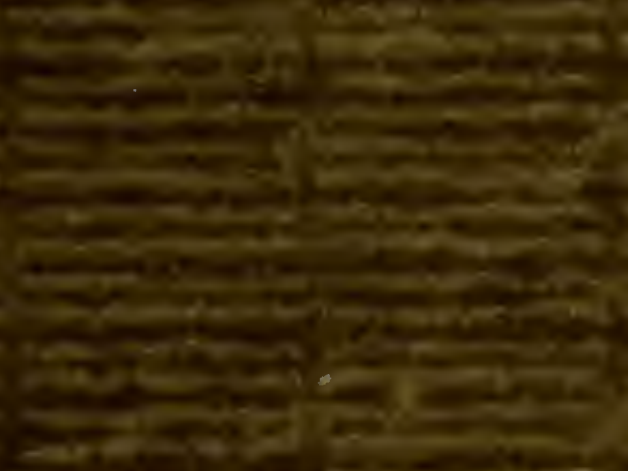

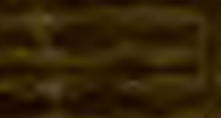
Lan

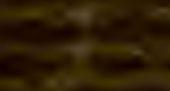

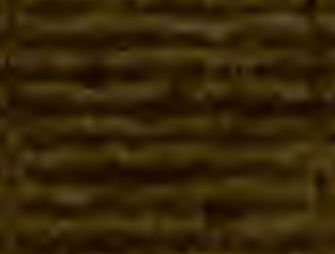

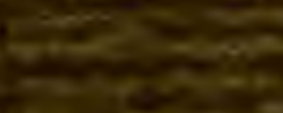

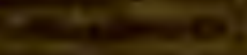

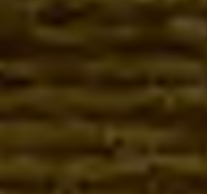

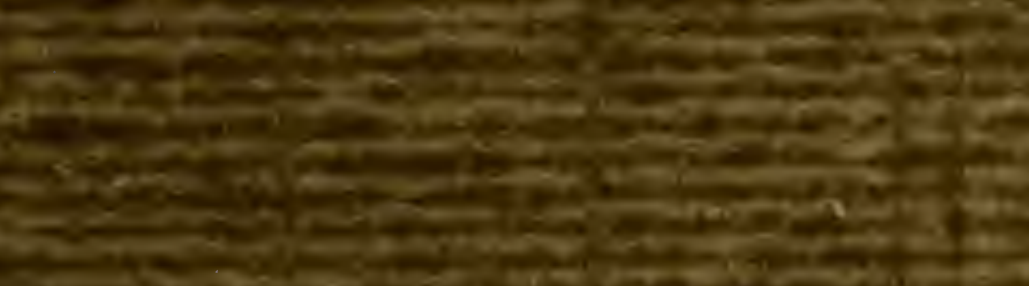

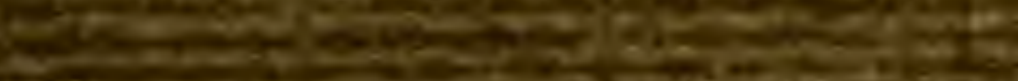

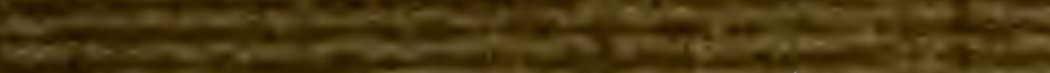

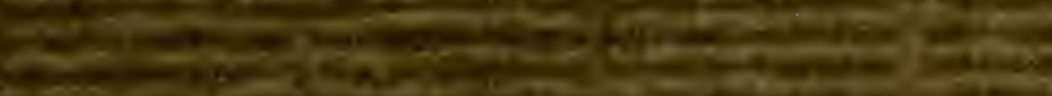

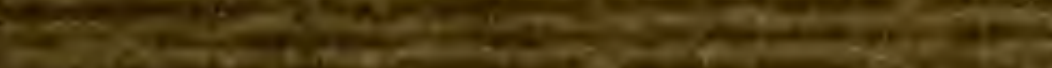

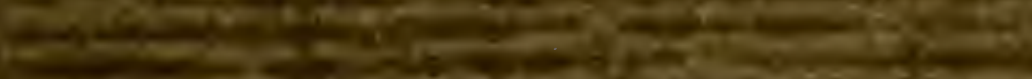

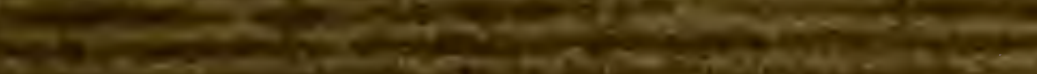

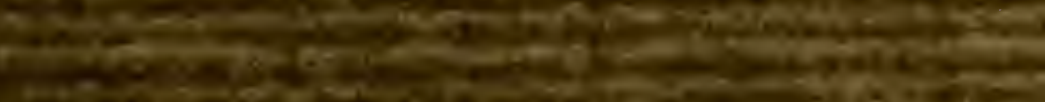

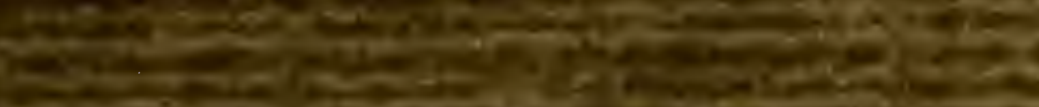

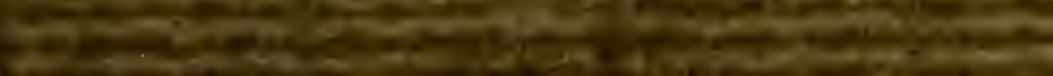

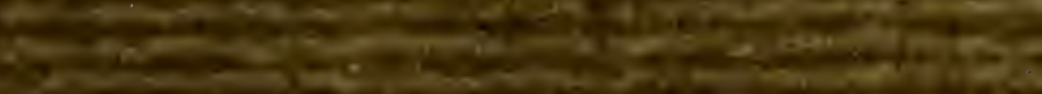

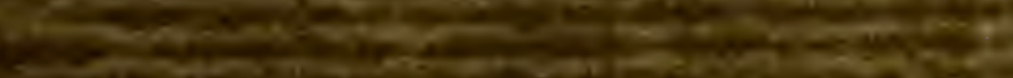

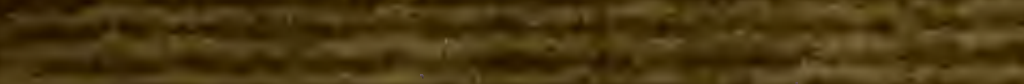

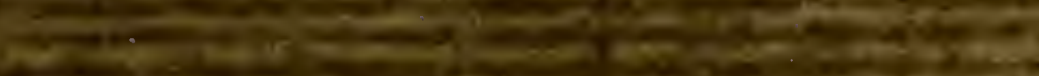
eatens

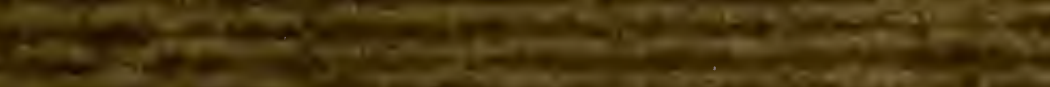

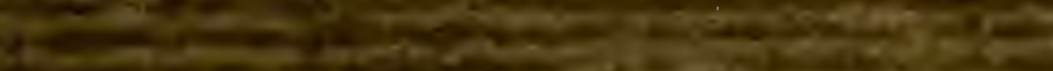

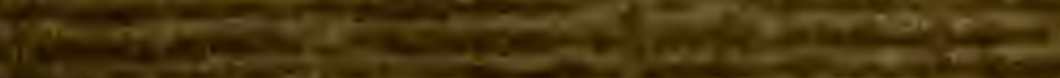

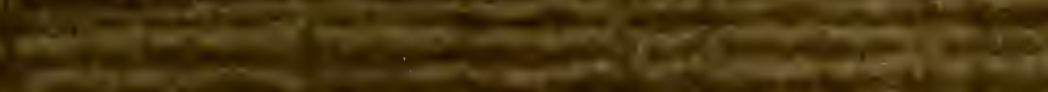

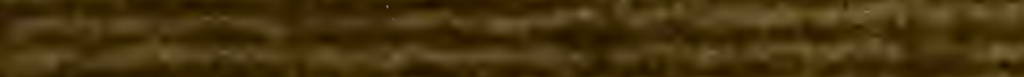

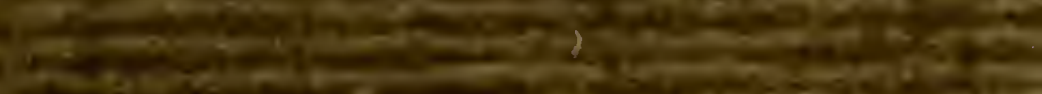

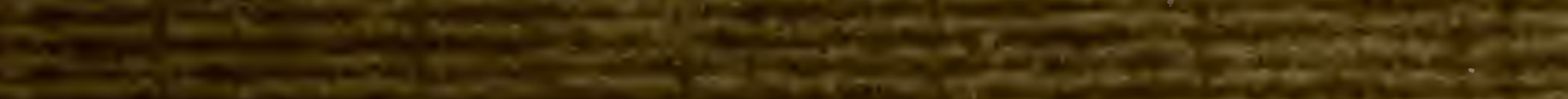

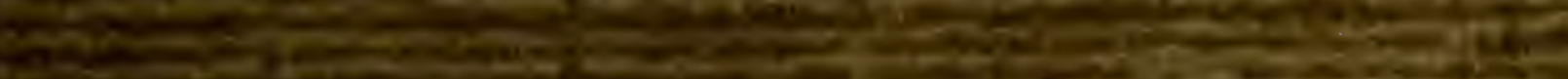
ats.

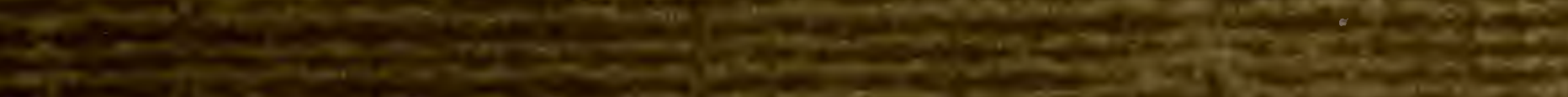

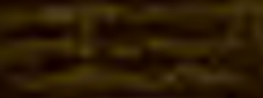

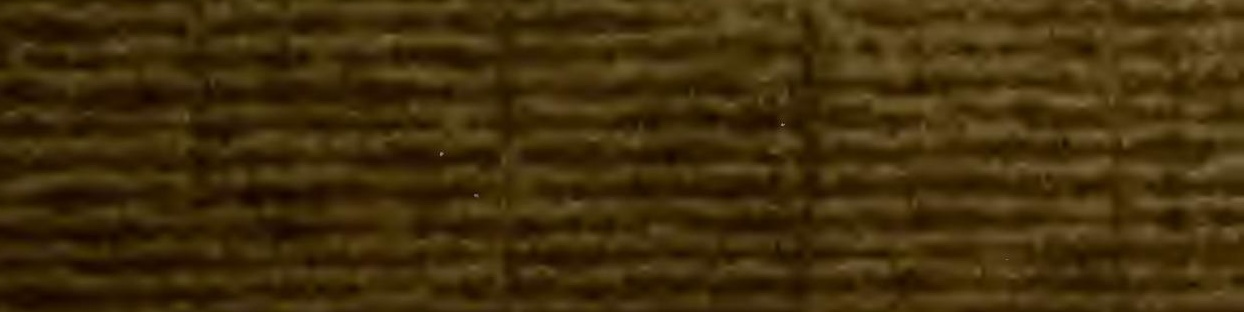




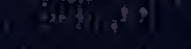

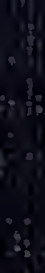

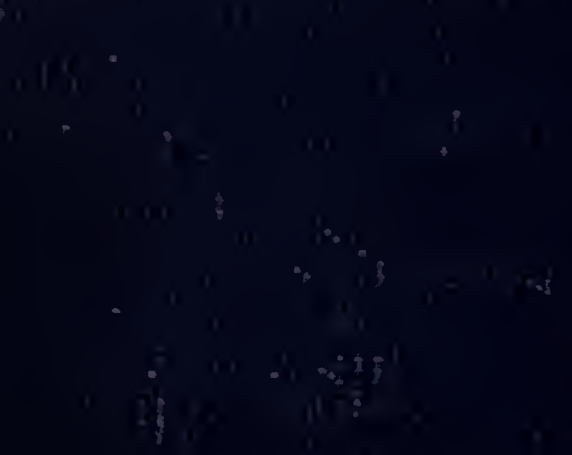

48
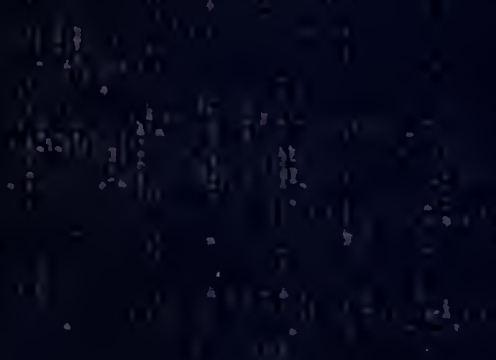

38 है

㩆 ?

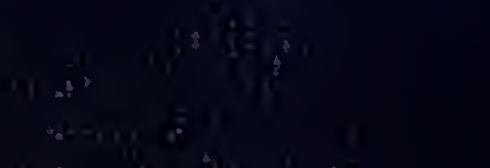

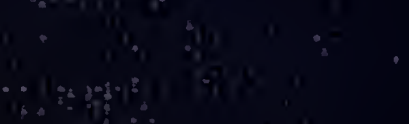

if. $i 0_{0}+1+11$ 